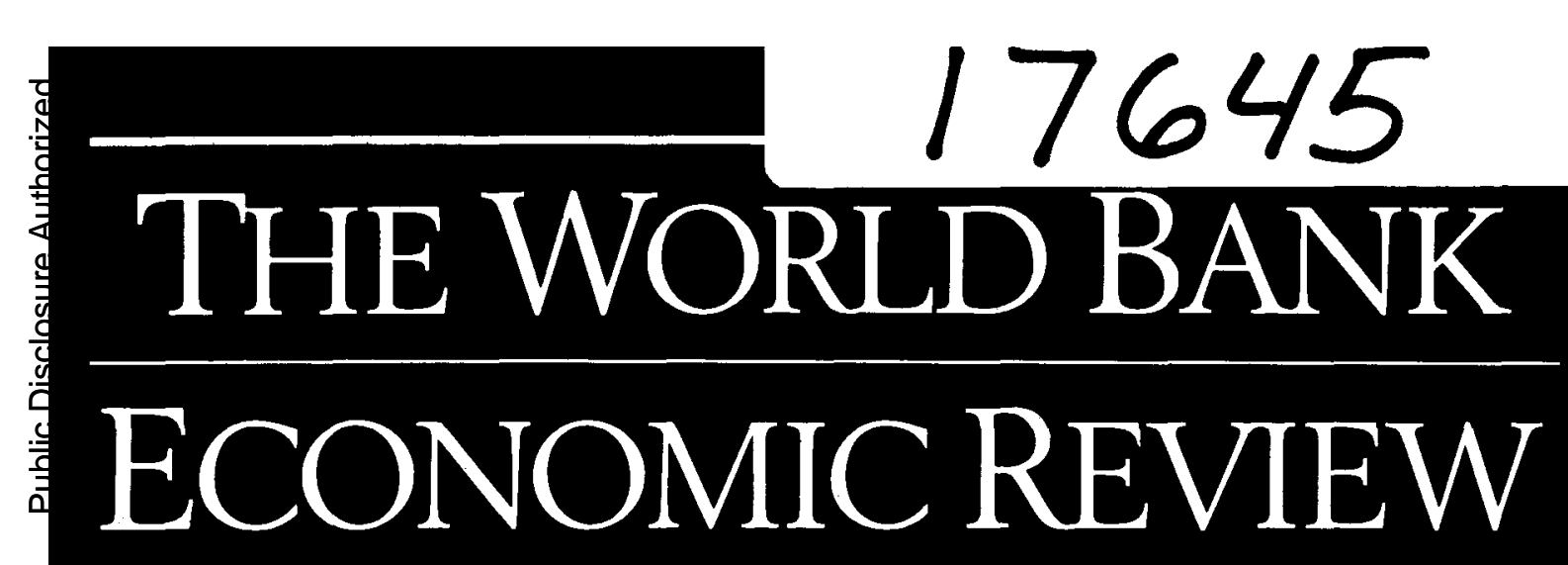

\title{
Moderate Inflation
}

Rudiger Dornbusch and Stanley Fischer

\section{External Shocks, Purchasing Power Parity, and the Equilibrium Real Exchange Rate}

Shantayanan Devarajan, Jeffrey D. Lewis, and Sherman Robinson

Obstacles to Developing Indigenous Small and Medium Enterprises: An Empirical Assessment

$$
\text { Brian Levy }
$$

Estimating Returns to Scale with Large, Imperfect Panels: An Application to Chilean Manufacturing Industries

M. Daniel Westbrook and James R. Tybout

Theoretical Implications of Imperfect Competition on Quota License Prices and Auctions

Kala Krishna 
EDITOR

Mark Gersovitz

CONSULTING EDITOR

Sandra Gain

EDITORIAL BOARD

Kaushik Basu, University of Delhi

Guillermo Calvo, International Monetary Fund

Alberto Giovannini, Columbia University

Mark R. Rosenzweig, University of Pennsylvania

Joseph Stiglitz, Stanford University

\author{
Mario I. Blejer \\ Gregory K. Ingram \\ Mieko Nishimizu \\ John Page \\ Jacques van der Gaag
}

The World Bank Economic Review is a professional journal for the dissemination of World Bank-sponsored research that informs policy analyses and choices. It is directed to an international readership among economists and social scientists in government, business, and international agencies, as well as in universities and development research institutions. The Review emphasizes policy relevance and operational aspects of economics, rather than primarily theoreti$\mathrm{cal}$ and methodological issues. It is intended for readers familiar with economic theory and analysis but not necessarily proficient in advanced mathematical or econometric techniques. Articles will illustrate how professional research can shed light on policy choices. Inconsistency with Bank policy will not be grounds for rejection of an article.

Articles will be drawn primarily from work conducted by World Bank staff and consultants. Before being accepted for publication by the Editorial Board, all articles are reviewed by two referees who are not members of the Bank's staff; articles must also be recommended by at least one external member of the Editorial Board.

The Review may on occasion publish articles on specified topics by non-Bank contributors. Any reader interested in preparing such an article is invited to submit a proposal of not more than two pages in length to the Editor.

The views and interpretations in articles published are those of the authors and do not necessarily represent the views and policies of the World Bank or of its executive directors or the countries they represent. When maps are used, the designations employed are solely for the convenience of the reader and do not imply the expression of any opinion whatsoever on the part of the World Bank or its affiliates concerning the legal status of any country, territory, city, or area, or concerning the delimitations of its boundaries or national affiliation.

Comments or brief notes responding to Review articles are welcome and will be considered for publication to the extent that space permits. Please direct all editorial correspondence to the Editor, The World Bank Economic Review, The World Bank, Washington, D.C. 20433, U.S.A.

The World Bank Economic Review is published three times a year (January, May, and September) by the World Bank. The annual subscription fee is US\$25 for individuals and $\$ 45$ for institutions. Single copies may be purchased at $\$ 10.95$. Subscription orders should be sent to: World Bank Publications, Box 7247-7956, Philadelphia, PA 19170-7956 U.S.A.

Subscriptions to The World Bank Economic Review are available without charge to readers with mailing addresses in developing countries and in socialist economies in transition. Written request is required every three years to renew such subscriptions.

(C) 1993 The International Bank for Reconstruction and Development / THE WORLD BANK All rights reserved

Manufactured in the United States of America ISSN 0258-6770

Material in this journal is copyrighted. The World Bank encourages dissemination of its work and will normally give permission promptly and, when the intended reproduction is for noncommercial purposes, without asking a fee. Permission to make photocopies is granted through the Copyright Clearance Center, 27 Congress Street, Salem, MA 01970 U.S.A.

This journal is indexed regularly in Current Contents/Social or Behavioral Sciences, Index to International Statistics, Journal of Economic Literature, Public Affairs Information Service, and Social Sciences Citation Index ${ }^{\circledast}$. It is available in microform through University Microfilms, Inc., 300 North Zeeb Road, Ann Arbor, Michigan 48106, U.S.A. 


\section{The World Bank Economic Review}

Volume 7

January 1993

Number 1

Moderate Inflation

Rudiger Dornbusch and Stanley Fischer

External Shocks, Purchasing Power Parity, and the

Equilibrium Real Exchange Rate

Shantayanan Devarajan, Jeffrey D. Lewis, and

Sherman Robinson

Obstacles to Developing Indigenous Small and Medium

Enterprises: An Empirical Assessment Brian Levy

Estimating Returns to Scale with Large, Imperfect

Panels: An Application to Chilean Manufacturing

Industries

M. Daniel Westbrook and James R. Tybout

Theoretical Implications of Imperfect Competition on

Quota License Prices and Auctions

Kala Krishna 


\title{
Moderate Inflation
}

\author{
Rudiger Dornbusch and Stanley Fischer
}

\begin{abstract}
Inflation persists at moderate rates of 15 to 30 percent in all the countries that successfully reduced triple digit inflations in the 1980s. Several other countries, for example Colombia, have experienced moderate inflation for prolonged periods. Theories of persistent inflation can be classified into those that emphasize seigniorage as a source of government finance and those that emphasize the costs of ending inflation. We examine the sources and persistence of moderate inflation episodes. Most episodes of moderate inflation were triggered by commodity price shocks and were brief; very few ended in higher inflation. This article presents case studies of eight countries, including three that now suffer from moderate inflation and four that successfully moved down to single-digit inflation rates. The roles of seigniorage, indexation and disindexation, the exchange rate commitment, and monetary and fiscal policy are examined. The evidence suggests that seigniorage plays no more than a modest role in the persistence of moderate inflations and that such inflations can be reduced only at a substantial short-term cost to growth.
\end{abstract}

Much attention has been paid to the process and stabilization of extreme inflations, at rates well in excess of 100 percent a year (Bruno and others 1988, 1991; Dornbusch, Sturzenegger, and Wolf 1990). Much less attention has been devoted to the inflationary problem in countries that are stuck with stubborn low, double-digit inflation of around 20 percent a year, often in the aftermath of stabilization programs that have successfully brought extreme inflations to an end. In the context of European disinflations in the 1980s, a parallel discussion has focused on how the European Monetary System (EMS) may have played a central role in allowing such countries as Ireland and Italy to reduce their inflation rates to single-digit levels.

We focus in this article on the behavior of inflation in countries that occupy the inflationary middle ground, with persistent annual inflation rates of 15 to 30

Rudiger Dornbusch and Stanley Fischer are with the Department of Economics at the Massachusetts Institute of Technology (MIT) and with the National Bureau of Economic Research (NBER). The research reported here was supported by the World Bank. The authors are grateful to the referees and Ravi Kanbur; to seminar participants at MIT, NBER, the University of Pennsylvania, and Harvard, Yale, and Columbia universities for helpful comments; to Russ Cheetham, Heywood Fleisig, Danny Leipziger, and Lisette Price for providing information; and to Jim Morsink, Tom Skinner, and Mursaleena Islam for valuable research assistance.

(C) 1993 The International Bank for Reconstruction and Development/THE WORLD BANK 
percent. An example, shown in figure 1, is Colombia, where inflation has hovered in the 20 to 30 percent range for more than a decade. The same pattern of persistent inflation in the 20 percent range has prevailed in Bolivia, Chile, Costa Rica, Egypt, El Salvador, Ghana, Hungary, Iceland, Israel, Mexico, and South Africa. In each instance, inflation is too high to be disregarded and to permit a fixed exchange rate. But it is evidently also too low to warrant the apparent political and economic costs of a frontal attack on the problem.

We seek to answer three basic questions about moderate inflations. First, what are the causes of moderate inflation? Second, are these inflations stable, or does a moderate inflation rate tend to increase unless definite policies are put in place to reduce it? And third, what policies will move a country from the moderate-inflation range to single-digit inflation?

We start by reviewing positive theories of inflation, including those that focus on seigniorage as well as those that emphasize Phillips curve-type tradeoffs. From there we proceed to a statistical overview of countries that have experienced periods of moderate inflation. We catalog moderate-inflation episodes since the mid-1950s, detailing whether the country moved out of the moderateinflation category successfully by reducing inflation, moved out unsuccessfully by moving on to higher inflation, or remained in about the same inflationary range.

Figure 1. The Rate of Inflation in Colombia, 1971-91

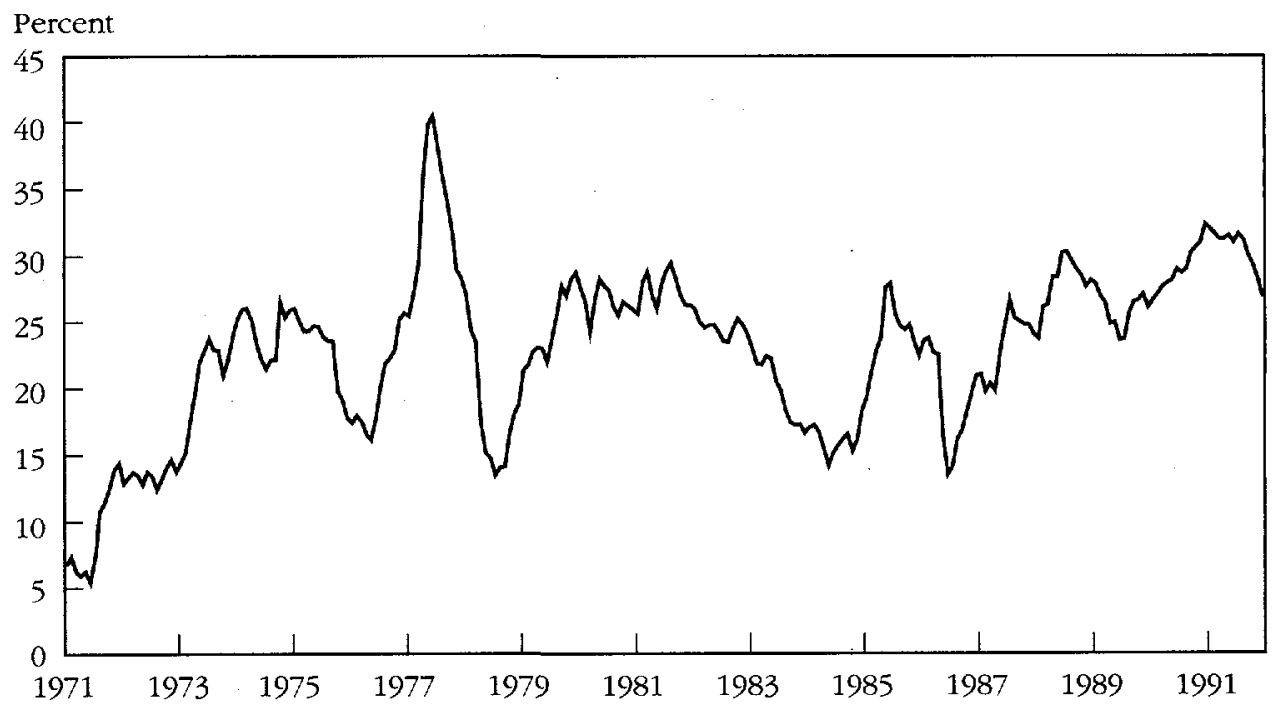

Note: The rate of inflation is measured by the change in the 12-month consumer price index. Data are monthly from January 1971 to December 1991.

Source: International Monetary Fund, International Financial Statistics (various issues). 
Table 1. Inflationary Experience in the Eight Case Studies

\begin{tabular}{lllll}
\hline \multicolumn{2}{c}{ Current moderate inflation } & & \multicolumn{2}{c}{ Former moderate inflation } \\
\cline { 2 - 3 } $\begin{array}{c}\text { Reached from high } \\
\text { inflation }\end{array}$ & $\begin{array}{c}\text { Reached from low } \\
\text { inflation }\end{array}$ & & $\begin{array}{l}\text { Inflation } \\
\text { now high }\end{array}$ & $\begin{array}{l}\text { Inflation } \\
\text { now low }\end{array}$ \\
\hline Chile & Colombia & Brazil & $\begin{array}{l}\text { Indonesia } \\
\text { Mreland } \\
\end{array}$ \\
& & & $\begin{array}{l}\text { Korea, Rep. of } \\
\text { Spain }\end{array}$ \\
\hline
\end{tabular}

We then present eight brief case studies of countries that have experienced moderate-inflation episodes: Brazil, Chile, Colombia, Indonesia, Ireland, the Republic of Korea, Mexico, and Spain. Their inflationary experience is summarized in table 1 . We are particularly interested in the countries that successfully disinflated from the moderate range. So far as we are aware, Indonesia is the only country that in the period since 1960 has suffered sustained extreme inflation (more than 100 percent) and then stabilized to the single-digit range. Of course, the classic hyperinflation countries achieved that feat earlier. In the case studies, we pursue the factors that determined the choice between allowing the inflation to continue and disinflating. We detail the implementation of disinflation policies in those countries that succeeded in stabilizing, by examining the exchange rate commitment and the use of incomes policy and trade liberalization, as well as by examining monetary and fiscal policies. We also discuss the costs of stabilization.

In the concluding section we draw on the case studies to summarize some lessons about disinflation from moderate inflation.

\section{WHY IS THERE INFLATION?}

There are basically two answers to the question of why there is inflation. One is that inflation is an integral part of a country's public finances. The other is that inflation continues because it is too hard or too costly to stop.

\section{Inflation and Public Finance}

At least since the $1920 \mathrm{~s}$ it has been understood that money creation is one way of financing budget deficits. In his classic article, Keynes (1923, chapter 2), in commenting on the hyperinflation experiences of Germany and Russia, vividly pointed out how even the weakest government always has one way left to pay its bills, namely, printing money. It might be thought that the seigniorage argument is relevant only to economies with extremely high inflation, but of course that is not the case. (See, for example, Phelps 1973 and Fischer 1983 on optimal inflation in a theory of public finance.) As table 2 shows, inflationary money creation accounts for a significant portion of government revenue even in economies with moderate rates of inflation. 
Table 2. Inflation and Seigniorage in Three Countries with Moderate Rates of Inflation (percent)

\begin{tabular}{lccc}
\hline Country & Inflation & Seigniorage $^{\mathrm{a}}$ & $\begin{array}{c}\text { Seigniorage as a } \\
\text { percentage of gov- } \\
\text { ernment revenue }^{\mathrm{b}}\end{array}$ \\
\hline Colombia, 1976-85 & 23.4 & 2.5 & 17.6 \\
Greece, 1982-87 & 19.7 & 2.6 & 11.2 \\
Portugal, 1982-87 & 19.3 & 3.5 & 6.5 \\
\hline
\end{tabular}

a. Change in high-powered money as a percentage of GDP.

b. Government revenue including seigniorage.

Source: International Monetary Fund, International Financial Statistics (various issues).

What predictions can we make from the seigniorage argument? In his classic work, Cagan (1956) introduced the notion of a revenue-maximizing rate of inflation and showed that most countries undergoing hyperinflations were inflating at well beyond revenue-maximizing rates. Friedman (1971) noted the role of real income growth as a source of seigniorage revenue. The revenue from money creation can be written as the sum of two terms, the first arising from inflationary money creation, the second from growth-induced increases in money demand:

$$
\dot{M} / P=[\pi+(n+\eta g)] m
$$

where $M$ is the quantity of high-powered money, $P$ an index of prices, $\pi$ the rate of inflation, $n$ the growth rate of population, $\eta$ the income elasticity of real money demand, $g$ the growth rate of real per capita income, and $m$ per capita real balances. Friedman focused on the tradeoff between the seigniorage revenue from inflationary money creation, $\pi m$, and the revenue that accrues from money creation linked to economic growth, $(n+\eta g) m$. With higher rates of inflation, real balances are lower and hence the growth benefits apply to a smaller base.

Suppose the demand for real cash balances takes the Cagan form, $M / P=$ $N f(y) e^{-b \pi}$, where $N$ denotes the population size. Then the revenue-maximizing rate of inflation, $\pi^{*}$, is given by

$$
\pi^{*}=1 / b-(n+\eta g)
$$

where the term $(n+\eta g)$ is the Friedman modification. At high inflation rates, however, the Friedman modification leads to relatively little change in the revenue-maximizing inflation rate. Cagan (1956) estimates $b$ (denoted $\alpha$ in his paper) to be about six months, or 0.5 years. With $b=0.5$, the peak of the seigniorage Laffer curve would be reached at 200 percent a year. Assuming that $\eta$ is unity, the revenue-maximizing inflation rate would be 190 percent, even for a real growth rate as high as 10 percent a year. The illustrative calculations in table 3 show how sensitive the revenue-maximizing inflation rate is to the estimate of $b$, and how relatively insensitive it is to the Friedman correction. 
Table 3. The Revenue-Maximizing Rate of Inflation in the Friedman Approach (percent per year)

\begin{tabular}{lcccc}
\hline $\begin{array}{l}\text { Rate of growth of real } \\
\text { per capita income, } \mathrm{g}\end{array}$ & \multicolumn{4}{c}{ Value of $\mathrm{b}$} \\
\cline { 2 - 5 } (percent) & 0.25 & 0.50 & 1.00 & 5.00 \\
\hline 0.00 & 398.0 & 198.0 & 98.0 & 18.0 \\
0.03 & 393.5 & 193.5 & 93.5 & 13.5 \\
0.06 & 389.0 & 189.0 & 89.0 & 9.0 \\
\hline
\end{tabular}

Note: The revenue-maximizing rate of inflation is calculated using equation 2 , with $n=0.02$ and $\eta=1.5$.

Bailey (1956) was the first to study the optimal-inflation tax rate, which is of course below the revenue-maximizing rate. The optimal inflation rate is calculated by equating the marginal social cost of raising government revenue through inflation with the marginal social cost of alternative sources of revenue. Bailey's calculations, which do not take account of growth, imply that

$$
\pi^{* *}=\mu /(1+\mu) b
$$

where $\pi^{* *}$ is the optimal-tax inflation rate and $(1+\mu)$ is the marginal social cost of raising an extra dollar in tax revenue. Table 4 shows tax-optimal inflation rates calculated from equation 3 .

The Bailey analysis appears to put tax-optimal inflation rates in the moderateinflation range. ${ }^{1}$ However, we are skeptical of the public finance argument for moderate inflation, because of the costs of inflation other than those arising from the need to economize on money holding and because of the gradual shift away from money holding that is common in moderate-inflation as well as highinflation economies. We do, however, accept the implication of the Bailey analysis that inflation rates will be higher in countries where alternative sources of revenue are costly. Bailey's results thus help account for generally higher inflation rates in Latin American countries, which have had great difficulty raising normal tax revenues.

1. Bailey obtained a low, tax-optimal rate of inflation because he assumed a very low collection cost (only 7 percent of revenue) and had a high $b(0.75)$.

Table 4. The Optimal Rate of Inflation in the Bailey Approach (percent per year)

\begin{tabular}{llrr}
\hline & \multicolumn{3}{c}{ Value of $\mathrm{b}$} \\
\cline { 2 - 4 }$\mu$ & 0.25 & 0.50 & 1.00 \\
\hline 0.1 & 36.4 & 18.2 & 9.1 \\
0.2 & 66.7 & 33.3 & 16.7 \\
0.5 & 133.3 & 66.6 & 33.3 \\
\hline
\end{tabular}

Note: The optimal rate of inflation is calculated using equation 3 . 


\section{Game-Theoretic Complications}

The central point of the simplest game-theoretic equilibrium models is that the public adjusts to any credible change in policy. But if the government has an incentive to mislead the public, then the public anticipates this possibility and the only viable equilibrium is one where the government's marginal incentive to cheat is balanced by the marginal cost of doing so. This is typically a "worse" equilibrium than could be attained if opportunistic government behavior could be ruled out.

Barro (1983) and Bruno (1991) have placed the seigniorage argument in a game-theoretic context using the Barro-Gordon (1983) approach to the problem of precommitment (see, too, Kiguel and Liviatan 1990). Consider a policymaker who maximizes an objective function that has both seigniorage and the inflation rate as arguments:

$$
V=\pi L\left(\pi^{*}\right)-\tau \pi^{2} / 2 .
$$

The policymaker optimizes conditional on the rate of expected inflation, $\pi^{*}$, and would like the public to have low expectations of inflation, so that the money base on which the inflation tax is imposed is high. But the equilibrium under rational expectations requires that the public's expectations be correct, so that in equilibrium, $\pi=\pi^{*}$. The equilibrium inflation rate in a situation without precommitment is therefore given by

$$
\pi=L(\pi) / \tau \text {. }
$$

Figure 2 shows the conventional seigniorage-Laffer curve, $O L$, for a Cagan demand function with maximum revenue at point $A$ and the corresponding inflation rate of $\pi_{0}$. Bruno and others (1991) show that the equilibrium gametheoretic inflation rate may exceed the revenue-maximizing rate of inflation. Two competing considerations enter. Although the marginal collection cost of seigniorage, $\tau \pi$, works to dampen inflation, the absence of precommitment tends to raise the inflation rate.

If the only social cost of inflation were the area under the demand curve for money, then the game-theoretic analysis would imply a higher inflation rate than the optimal-tax analysis. This expanded model of seigniorage could therefore support the notion of equilibrium inflation rates in the 15 to 30 percent range.

\section{Implications for Stabilization}

The seigniorage argument-whether in the optimal-tax or the game-theoretic mode-makes inflation plausible because, within a given tax structure, inflation is a relatively low-cost way of raising revenue. But clearly that is only true within a given structure. If the marginal cost of raising government revenue can be lowered through tax reform, then the optimal inflation rate will be reduced as well. In this perspective, tax reform accompanies and supports inflation stabilization. 
Figure 2. Seigniorage and Inflation

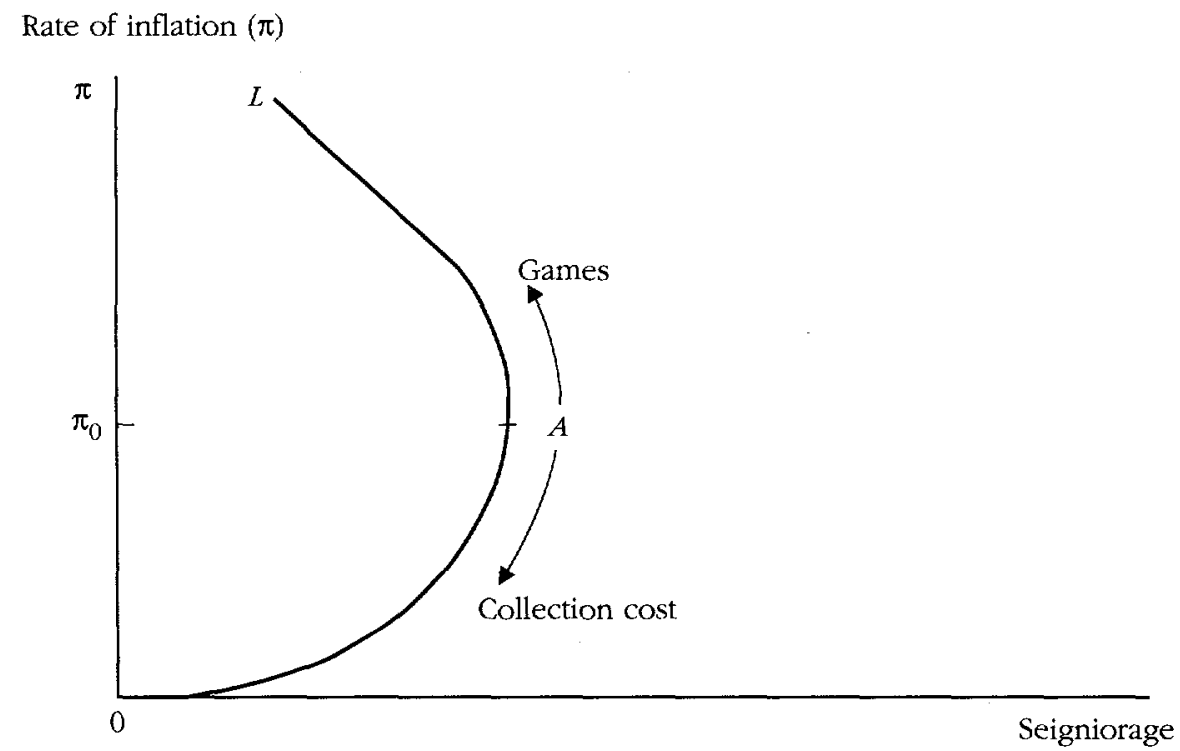

\section{Inflation and Unemployment}

The main alternative game-theoretic model of inflation also focuses on the lack of precommitment, but the cornerstone of the game is unemployment rather than seigniorage. It is assumed that wages and prices are fully flexible and there would be no problem in shifting to a noninflationary equilibrium if only the government could credibly commit itself. But the government has an incentive to cheat and surprise.

In Barro and Gordon's (1983) model the government minimizes a loss function, $V$, in which the arguments are the deviation of unemployment from the government's desired unemployment rate, $k u^{*}$, and inflation. Because of distortions, for example in the tax structure, or of taste differences, the government's target rate of unemployment is only a fraction ( $k$ in equation 6$)$ of the natural rate at which the labor market clears and that governs inflation dynamics:

$$
V=\left(u-k u^{*}\right)^{2}+\alpha \pi^{2} \quad 0<k<1 .
$$

In the labor market, inflation depends on inflationary expectations $\left(\pi^{*}\right)$ and on the discrepancy between the actual $(u)$ and natural $\left(u^{*}\right)$ rates of unemployment:

$$
\pi=\pi^{*}-\beta\left(u-u^{*}\right) .
$$

The government maximizes $V$ subject to the inflation equation (equation 7), 
taking inflationary expectations as given. In equilibrium the solution must satisfy $\pi=\pi^{*}$. Equilibrium inflation therefore is

$$
\pi=(1-k) u^{*} / \alpha \beta .
$$

Inflation in this model is strictly the result of a lack of precommitment. Equilibrium inflation does not come as a surprise, and as a result it fails to reduce unemployment below the natural rate. The equilibrium level of inflation is higher, the higher the wedge between the natural and target rates of unemployment, the more the government is concerned with the employment objective rather than with inflation, and the smaller the impact of unemployment on inflation.

This model could support the idea of steady inflation at 20 or 30 percent. However, the parameters that appear in equation 8 have not been estimated in a way that makes it possible to narrow down the implied range of inflation.

The general spirit of this model can be taken in several directions. One possibility is that the public does not know the characteristics of the policymaker. In this case, learning and reputation building come into play (see Andersen 1989; Persson 1988; Persson and Tabellini 1989; Driffill 1989; Blackburn and Christensen 1989). Taking account of reputation generally reduces the equilibrium inflation rate below that implied by equation 8 , but also suggestsrealistically-that inflation rates are likely to be lower in countries with more stable governments, where policymakers and the institutions in which they operate have the opportunity to establish reputations.

The central place of precommitment and reputation in game-theoretic models supports the notion embodied in the creation of independent central banks: that institutions should be designed to reduce the incentives for opportunistic behavior and ambiguity about preferences. For example, appointing conservatives to run the central bank would lead to lower inflation. So would positive disincentives for policymakers to create inflation.

\section{Inflation Too Costly to Stop}

A different motive for inflation comes from the observation, or at least the belief, that inflation is costly to stop. One might call this the "Brookings School" view. Once commonplace (see, for example, Tobin 1980 discussing the prospects for disinflation in the 1980s), it came under attack in the $1980 \mathrm{~s}$, notably by Sargent $(1982,1986)$. Sargent brought evidence from the end of hyperinflations, and from the United Kingdom and France in the 1920s, to shift the focus of attention to the credibility issue and away from the notion of price stickiness that does not result from the slow adjustment of expectations.

A typical persistence model is presented in the following equations, where $w$ denotes wage inflation and $e$ the rate of depreciation of the exchange rate. The disturbance term, $\psi$, is expressly recognized, because supply shocks play an important role in the inflation process: 


$$
\begin{array}{cr}
\pi=\alpha w+(1-\alpha) e+\psi & 0<\alpha<1 \\
w=\pi_{-1}-\lambda u & \\
e=\beta \pi+(1-\beta) \pi_{-1} & 0<\beta<1 \\
\pi=\pi_{-1}+\theta \psi-\alpha \lambda \theta u & \theta=1 /[1-\beta(1-\alpha)] \\
u=u_{-1}-\tau(m-\pi)-\phi(e-\pi) . &
\end{array}
$$

The model includes cost-based pricing (equation 9), a wage-setting equation (10), and an exchange rate rule (11). These three equations imply an accelerationist Phillips curve (equation 12); the model is completed by an aggregate demand equation with real money growth and real depreciation as the driving forces (equation 13). The model assumes persistence, because lagged inflation appears mechanically as a determinant of current wage and price inflation.

\section{Indexation}

In economies where inflation is substantial-say, 20 percent a year-some implicit or explicit form of indexation is unavoidable. Indexation increases inflationary inertia for at least two reasons. First, indexation leads to longer contracts than would exist in its absence, and longer contracts generally increase inertia. ${ }^{2}$ Second, the typical indexing formula used in practice tends to make the real wage a negative function of the inflation rate. ${ }^{3}$ This means that the real wage rises when inflation is reduced, implying higher unemployment. ${ }^{4}$

If wages are set by a formula depending mainly on the past behavior of inflation, there will be very little scope to enlist forward-looking expectations effects in disinflating. When inflation is chronic, either a suspension of indexation or else protracted high unemployment will be inevitable in the process of stabilization. As equation 10 shows, if current wage inflation is determined by past price inflation, then more work has to be done by unemployment to bring down wage inflation.

\section{Combining Inertia and Expectations}

The above model neglects explicit expectations. In the overlapping-contract models of Fischer $(1977,1986)$, Taylor $(1980,1983)$, and Dornbusch (1980), expectations are forward-looking but long-term contracts introduce an element

2. Taylor (1982) and Fischer (1986) show that indexation can speed up the response of prices to a reduction in money growth. The comparison that is being made in these papers is between indexed wages and wages that are predetermined in contracts of the same length; the response is more rapid with indexed wages because they adjust sooner to any initial reduction in inflation achieved by policy.

3. This relationship has been examined by Modigliani and Padoa-Schioppa (1978) and Simonsen (1986); see Fischer (1988, equation 20).

4. Of course, the short-run impact of higher real wages also works through the demand side and on that account may well raise output, notably in the nontraded goods sector. This theme is familiar from the literature on contractionary devaluation. 
of inertia (see, too, Fellner and others 1982). In these rational expectations models, inflation is still linked to the past because existing wage settlements include expectations based on past information. But the more forward-looking the pricing and the shorter the contracts, the less recessionary a disinflation will be-provided, of course, that the change in policy affects expectations of future prices and wages.

With full credibility, policies that stabilize inflation without creating unemployment can, in principle, be designed in these models. However, nonrecessionary disinflation in these models typically takes very long and starts with either an increase in the money stock or a very slow reduction in money growth, which immediately raises the issue of credibility. The job can be done faster if unemployment is allowed, but the assumption of full credibility will, in practice, not be satisfied, and that may raise the unemployment cost substantially. ${ }^{5}$

\section{Innovations in Credibility Management}

Recent policy experiments have focused on enhancing credibility along with actual monetary disinflation. In Chile, for example, the Central Bank was formally made independent of the government in 1989. In New Zealand an elaborate agreement between the Treasury and the Central Bank in 1989 obliged the latter to achieve a stable price level by the end of 1992. Canada, too, is attempting to reduce inflation by amending the law to make price stability the Bank of Canada's sole policy target. Although the Canadian package is less ambitious than that of New Zealand, it, too, attempts to lower the cost of disinflation by directly influencing expectations (see Lipsey 1990, and the Bank of Canada's February 26, 1991, press release in Selody 1990). In Europe the E.Ms has served as a credibility-enhancing mechanism.

\section{Summary}

The policymaker who disinflates has to deal with two elements central to different models-seigniorage and the mechanics of wage-price dynamics. Significant amounts of seigniorage-2 to 3 percent of gross national product (GNP)-are typically being collected in countries with moderate inflation, and inflation will not stop in these countries unless the government deals with the fiscal problem by cutting expenditures or raising taxes.

5. Calvo (1983a, 1983b) has proposed a model of forward-looking price setting in which one can investigate the effect of a change in the monetary growth rate. A change in money growth immediately changes the inflation rate, but not the price level. Fuhrer and Moore (1990), noting tlat Calvo's model cannot account for sticky inflation, offer an ad hoc adaptation. Ball $(1990,1991)$, addressing the same issue, recognizes that in a Taylor setting, the level of prices-not their rate of change-has inertia. $\mathrm{He}$ concludes that disinflation ought to result in a boom, because the lower expectation of future prices leads, through the Taylor wage- and price-setting assumptions, to a reduction in the current price level and thus higher real balances. The standard outcome is that the start of a credible disinflation should be accompanied by a step increase in the money supply, to provide for the increased real balances demanded as a result of lower expected inflation. This mechanism is not present in the Ball model. 
Second, inflationary inertia, whether resulting from the slow adjustment of expectations or from the presence of contracts, has to be taken into account. A convenient starting point is to go back to equation 9, adding and subtracting lagged inflation on the right-hand side:

$$
\pi=\pi_{-1}+\alpha\left(w-\pi_{-1}\right)+(1-\alpha)\left(e-\pi_{-1}\right)+\psi .
$$

The equation underlines the persistence of inflation. Inflation today will be equal to inflation yesterday except for any combination of the following:

- Wage inflation falls below past price inflation. (This requires a break with any implicit or explicit backward-looking indexation. The suspension of indexation, or introduction of an incomes policy, could accomplish this.)

- Exchange depreciation falls below the rate of past inflation.

- Favorable supply shocks lead to disinflation without the need for the exchange rate or wages to take the lead.

More generally, for inflation to fall, there has to be a major break in the process whereby each sector, including the monetary authorities, accommodates the inflation rate of every other sector. Use of the exchange rate to initiate a disinflation is very common, but it risks leading to a situation of overvaluation, which then greatly complicates the unwinding phase. Policies that attempt to reduce inflation by stabilizing the nominal exchange rate or other governmentcontrolled prices run enormous risks of unsustainability if inflation fails to respond. Thus there can be no way of pursuing these policies to the bitter end; if they fail to reduce inflation, at some stage they have to be abandoned.

Sometimes the inflationary process is broken into by a change in the wage rules that move from compensating for past erosion of the purchasing power of wages to a forward setting based on expected inflation. If the stabilization program is indeed accompanied by a fundamental change in fiscal policy, then inertia can be reduced by a one-time suspension of indexation rules-for example, that workers and asset-holders forgo one inflation adjustment. Provided the new policies are consistent with low inflation, indexation can later be restored if that has to be done. But if all else fails, high unemployment will have to be used to slow inflation by reducing wage and demand pressures; that has been the rule in successful programs.

In the case studies below we will highlight how the problem of cutting into the inflationary process was addressed in each instance.

\section{Statistical OVerview}

There is need for a working definition of moderate inflation. The rate has to be high and persistent enough to set it apart from the problems of the United Kingdom or the United States, yet low enough to put it in a category clearly distinct from high, extreme, or hyperinflation. We define a moderate-inflation episode as one in which the annual inflation rate is in the 15 to 30 percent range for at least three years. 
The emphasis on the inflation being sustained is essential to set the experiences apart from supply-shock inflation. The upper limit of the range is not very important-whether to end at 25 or 30 percent-but the lower limit does affect the number and length of episodes. The duration is more significant; there would be many more episodes if we used a two-year duration and far fewer if we used a four-year duration-as can be seen in table 5 , which presents a list of the episodes of moderate inflation in the period since 1950, as well as in table 6, which lists moderate-inflation episodes by their duration. (Data are incomplete for the 1950s, and the weight of the experience therefore comes from the post-1960 period.)

Table 5 includes 55 episodes, drawn from the behavior of inflation in 131 countries. Just over half of these episodes-28 of them-started during the oil price shocks and lasted no more than four years. Clearly, many of the moderateinflation episodes were triggered by commodity price shocks. Table 5 leads us to raise a number of questions: Is there a high incidence of repeat offenders? The answer is clearly no. Where do countries that find themselves in moderateinflation spells come from and where do they go? Most countries come from low inflation. Leaving moderate inflation, they typically stay, on average, in the neighborhood of moderate inflation, or go back to a lower inflation rate. Very few transit to higher inflation. In table 5 , of the 48 cases for which post-episode information was available, 32 had average annual inflation rates below 15 percent for the following three years, 10 had annual inflation rates that averaged

Table 5. Inflation Rates before, during, and after Episodes of Persistent Moderate Inflation since 1950

\begin{tabular}{|c|c|c|c|c|}
\hline \multirow[b]{2}{*}{ Country } & \multirow[b]{2}{*}{$\begin{array}{l}\text { Period of } \\
\text { moderate } \\
\text { inflation }\end{array}$} & \multicolumn{3}{|c|}{ Average annual rate of inflation } \\
\hline & & $\begin{array}{l}\text { During the } \\
\text { period }\end{array}$ & $\begin{array}{l}\text { Three years } \\
\text { before the } \\
\text { period }\end{array}$ & $\begin{array}{c}\text { Three years } \\
\text { after the period }\end{array}$ \\
\hline \multicolumn{5}{|l|}{ Pacific } \\
\hline New Zealand & $\begin{array}{l}1975-77 \\
1980-82\end{array}$ & $\begin{array}{l}15.3 \\
16.2\end{array}$ & $\begin{array}{r}8.7 \\
13.3\end{array}$ & $\begin{array}{r}14.3 \\
9.7\end{array}$ \\
\hline \multicolumn{5}{|l|}{ Europe } \\
\hline Finland & $1974-76$ & 16.3 & 8.2 & 9.3 \\
\hline Greece & $1979-87$ & 20.7 & 12.7 & 15.6 \\
\hline Iceland & $1986-89$ & 21.6 & 48.4 & - \\
\hline \multirow[t]{2}{*}{ Ireland } & $1974-76$ & 18.6 & 9.7 & 11.5 \\
\hline & $1980-82$ & 18.6 & 11.4 & 8.2 \\
\hline \multirow{2}{*}{ Italy } & $1974-77$ & 17.8 & 7.1 & 16.0 \\
\hline & $1980-82$ & 18.5 & 14.7 & 11.6 \\
\hline Poland & $1983-86$ & 17.5 & 43.8 & 112.1 \\
\hline Portugal & $1974-85$ & 22.7 & 8.9 & 10.2 \\
\hline Spain & $1974-80$ & 17.6 & 9.3 & 13.7 \\
\hline \multirow[t]{2}{*}{ Turkey } & $1955-59$ & 18.0 & 11.9 & 1.6 \\
\hline & $1973-77$ & 19.0 & 11.4 & 71.4 \\
\hline United Kingdom & $1974-77$ & 18.1 & 8.6 & 13.2 \\
\hline \multirow{2}{*}{ Yugoslavia } & $1971-75$ & 19.3 & 7.9 & 13.1 \\
\hline & $1977-79$ & 16.5 & 18.9 & 34.1 \\
\hline
\end{tabular}


Table 5. (continued)

\begin{tabular}{|c|c|c|c|c|}
\hline \multirow[b]{2}{*}{ Country } & \multirow[b]{2}{*}{$\begin{array}{l}\text { Period of } \\
\text { moderate } \\
\text { inflation }\end{array}$} & \multicolumn{3}{|c|}{ Average annual rate of inflation } \\
\hline & & $\begin{array}{c}\text { During the } \\
\text { period }\end{array}$ & $\begin{array}{l}\text { Three years } \\
\text { before the } \\
\text { period }\end{array}$ & $\begin{array}{c}\text { Three years } \\
\text { after the period }\end{array}$ \\
\hline \multicolumn{5}{|l|}{ Africa } \\
\hline Ethiopia & $1977-79$ & 15.7 & 14.6 & $5.5^{b}$ \\
\hline Liberia & $1973-75$ & 17.5 & 1.6 & $6.4 b$ \\
\hline Seychelles & $1972-75$ & 20.6 & 一 & 13.9 \\
\hline Sierra Leone & $1974-76$ & 17.2 & 3.3 & $13.5^{\mathrm{b}}$ \\
\hline Somalia & $1974-76$ & 17.3 & 1.0 & $15.0^{\mathrm{b}}$ \\
\hline South Africa & $1985-87$ & 17.0 & 12.8 & 13.9 \\
\hline \multirow{2}{*}{ Sudan } & $1973-75$ & 21.8 & 6.3 & 12.7 \\
\hline & $1979-81$ & 25.2 & 22.5 & 36.7 \\
\hline Swaziland & $1979-81$ & 18.3 & 11.0 & 12.0 \\
\hline Zaire & $1972-74$ & 20.3 & 6.7 & 66.0 \\
\hline Zambia & $1976-78$ & 18.3 & 8.2 & 11.4 \\
\hline \multicolumn{5}{|l|}{ Asia and Pacific } \\
\hline \multirow[t]{2}{*}{ Korea, Rep. of } & $1974-76$ & 21.5 & 9.5 & 14.3 \\
\hline & $1979-81$ & 27.8 & 13.3 & 4.3 \\
\hline $\begin{array}{l}\text { Pakistan } \\
\text { Western Samoa }\end{array}$ & $1973-75$ & 23.6 & 5.1 & 7.8 \\
\hline Western Samoa & $1981-83$ & 18.4 & 15.4 & 9.4 \\
\hline \multicolumn{5}{|l|}{ Middle East } \\
\hline Bahrain & $1973-78$ & 18.5 & 4.2 & 5.8 \\
\hline \multirow[t]{2}{*}{ Egypt } & $1982-84$ & 16.0 & 13.6 & 18.6 \\
\hline & $1986-90$ & 20.5 & 15.0 & - \\
\hline \multirow{3}{*}{$\begin{array}{l}\text { Iran, Islamic Rep. of } \\
\text { Israel } \\
\text { Syria }\end{array}$} & $1980-83$ & 20.8 & 16.5 & 11.8 \\
\hline & $1987-90$ & 18.3 & 224.2 & - \\
\hline & $1980-82$ & 17.3 & 7.1 & $10.9 \mathrm{~b}$ \\
\hline \multicolumn{5}{|c|}{ Latin America and Caribbean } \\
\hline Bolivia & $1987-90$ & 15.3 & $4,435.8$ & - \\
\hline Brazil & $1968-72$ & 20.7 & 45.9 & 23.1 \\
\hline \multirow[t]{2}{*}{ Chile } & $1965-68$ & 24.3 & - & 27.6 \\
\hline & $1986-89$ & 17.8 & 26.0 & $-b$ \\
\hline \multirow[t]{2}{*}{ Colombia } & $1973-76$ & 22.1 & 9.7 & 25.2 \\
\hline & $1978-89$ & 23.1 & 25.4 & - \\
\hline Costa Rica & $1987-90$ & 18.3 & 13.0 & - \\
\hline \multirow[t]{2}{*}{ El Salvador } & 1979-81 & 15.6 & 10.7 & 12.2 \\
\hline & $1987-89$ & 20.8 & 21.9 & 25.5 \\
\hline Grenada & $1977-81$ & 19.6 & - & 6.5 \\
\hline Guyana & $1978-83$ & 17.5 & 8.4 & 16.0 \\
\hline Haiti & $1973-75$ & 18.2 & 4.7 & 3.6 \\
\hline Mexico & $1974-76$ & 18.3 & 7.4 & 21.6 \\
\hline Paraguay & $1955-57$ & 20.4 & 69.7 & 8.1 \\
\hline \multirow[t]{2}{*}{ Trinidad and Tobago } & $1973-75$ & 17.9 & 5.1 & 10.9 \\
\hline & $1979-81$ & 15.5 & 10.9 & 13.4 \\
\hline Uruguay & $1969-71$ & 20.4 & 96.0 & 83.6 \\
\hline
\end{tabular}

- Not availabie.

Note: All spells shown as ending in 1988 or earlier were completed. Some that were shown as ending in 1989 may not have been completed (data for 1990 were not available for all countries). Spells shown as ending in 1990 may be continuing.

a. Moderate inflation is defined as an annual inflation rate of 15 to 30 percent for at least three consecutive years.

b. Includes year(s) in which the inflation rate was between 14 and 15 percent.

Source: International Monetary Fund, International Financial Statistics (various issues). 
Table 6. Duration of Episodes of Moderate Inflation since 1950

\begin{tabular}{lcccccccc}
\hline & \multicolumn{7}{c}{ Consecutive years of moderate inflation } \\
\cline { 2 - 9 } Item & 3 & 4 & 5 & 6 & 7 & 8 & 9 & 12 \\
\hline Number of episodes & 31 & 12 & 6 & 2 & 1 & 0 & 1 & 2 \\
Percentage of total & 56.4 & 21.8 & 10.9 & 3.6 & 1.8 & 0 & 1.8 & 3.6 \\
\hline
\end{tabular}

a. Moderate inflation is defined as an annual inflation rate of 15 to 30 percent for at least three consecutive years.

between 15 and 30 percent, and only 6 had annual inflation rates that averaged more than 30 percent.

Table 6 summarizes the persistence of moderate-inflation episodes. The table shows the number of spells listed in table 5 that were of a given duration. Thus, for example, more than half the moderate-inflation spells lasted only three years. The evidence thus shows that most countries that enter the moderateinflation zone do not stay there very long: for most countries moderate inflation is a transitory experience. In very few countries does moderate inflation become a way of life: there are only six spells where inflation is in the 15 to 30 percent range for more than five years. The two longest spells are those of Portugal and Colombia, each lasting 12 years (and Colombia's still continues).

\section{CASe Studies}

In this section we offer several case studies, representing different transitions into or out of moderate inflation, as shown in table 1. We start with the countries that are currently experiencing moderate inflation after stabilizing a high inflation-Chile and Mexico. Other countries in this situation are Israel and Bolivia. We then examine the case of Colombia, which, having reached moderate inflation from low inflation, is the country with the longest-lasting moderate inflation. We turn next to Brazil, which stabilized a high inflation successfully and reached moderate inflation in 1968 , but then failed to stay in this region and returned to high inflation. We conclude with four countries that have successfully reduced moderate inflations and now experience low inflationRepublic of Korea, Indonesia, Ireland, and Spain.

\section{Chile}

Chile is today seen as the example of successful macroeconomic stabilization and structural adjustment. There is no question about the success, but there should also be no illusion about the cost at which these accomplishments were attained-violent political repression for almost two decades and mass unemployment until very recently.

Table 7 reviews key Chilean variables in the 1980 s, and figure 3 shows the path of inflation. 
Table 7. Macroeconomic Variables in Chile, 1980-89

\begin{tabular}{lcccrrrr}
\hline & $\begin{array}{c}\text { General } \\
\text { government } \\
\text { budget } \\
\text { deficita }\end{array}$ & $\begin{array}{c}\text { Real } \\
\text { interest } \\
\text { rate }^{\mathrm{b}}\end{array}$ & $\begin{array}{c}\text { Unem- } \\
\text { ployment } \\
\text { ratec }\end{array}$ & $\begin{array}{c}\text { Real } \\
\text { wage } \\
\text { index }\end{array}$ & $\begin{array}{c}\text { Real } \\
\text { exchange } \\
\text { rate }\end{array}$ & $\begin{array}{c}\text { inflation } \\
\text { rate } \\
\text { (percent) }\end{array}$ & $\begin{array}{c}\text { Seign- } \\
\text { iorage }\end{array}$ \\
\hline 1980 & 5.5 & 12.2 & 14.5 & 88 & 95 & 35.1 & 2.4 \\
1981 & 2.4 & 28.8 & 13.7 & 103 & 108 & 19.7 & -0.7 \\
1982 & -2.2 & 35.1 & 27.2 & 103 & 97 & 9.9 & -1.7 \\
1983 & -2.6 & 15.9 & 36.5 & 92 & 89 & 27.3 & 0.8 \\
1984 & -2.9 & 11.4 & 28.3 & 92 & 90 & 19.9 & 0.9 \\
1985 & -2.3 & 11.1 & 23.9 & 88 & 80 & 30.7 & 0.8 \\
1986 & -0.0 & 7.7 & 18.9 & 90 & 89 & 19.5 & - \\
1987 & 0.5 & 9.4 & 16.2 & 89 & 66 & 19.9 & - \\
1988 & -0.3 & 9.9 & 12.0 & 95 & 61 & 14.7 & - \\
1989 & - & - & - & - & 62 & 17.0 & - \\
\hline
\end{tabular}

- Not available.

a. Percentage of GDP.

b. Realized active rate (percent).

c. Includes participants in government work program.

d. $1980-82=100$.

e. The change in money base as a percentage of GDP.

Source: International Monetary Fund, Government Financial Statistics (various issues); International Monetary Fund, International Financial Statistics (various issues); CIEPLAN (various issues); Morgan Guaranty (various issues).

Figure 3. The Rate of Inflation in Chile, 1978-92

Percent

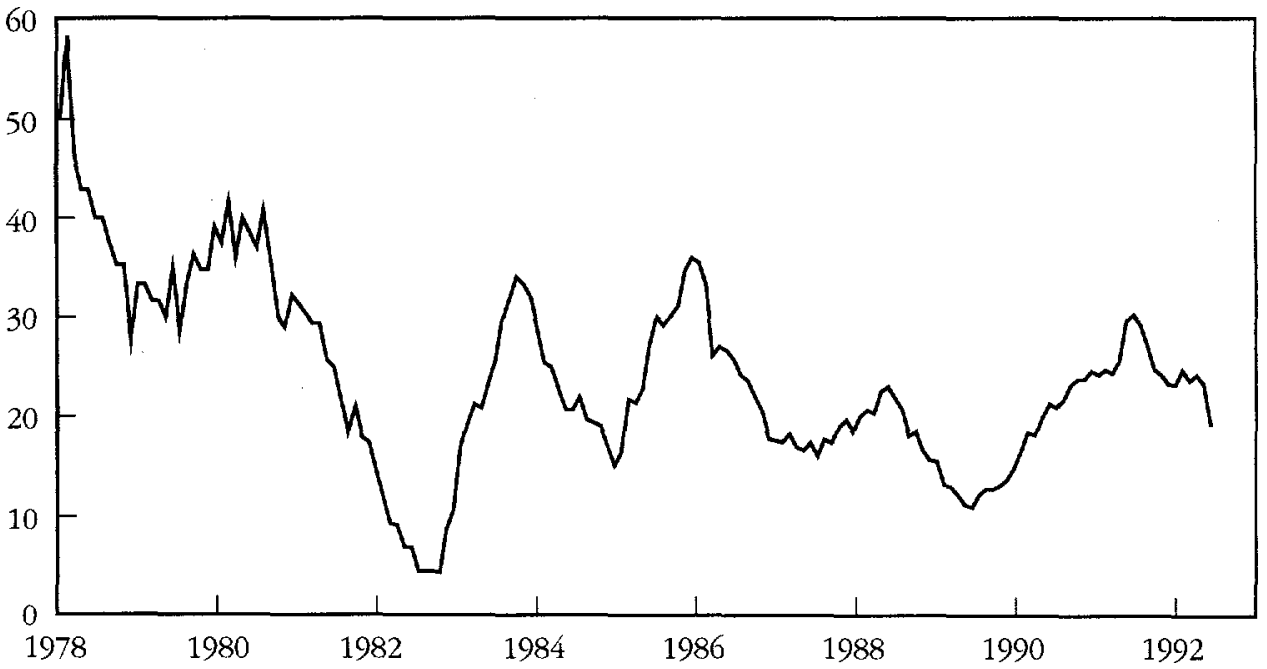

Note: The rate of inflation is measured by the change in the 12 -month consumer price index. Data are monthly from January 1978 to March 1992.

Source: International Monetary Fund, International Financial Statistics (various issues). 
The 1970 s miracle. Following the military coup in September 1973, the Pinochet government rapidly established fiscal austerity and tight monetary control. "Chicago monetarism" was the rule. From the shambles left in the aftermath of Allende's populism, the economy was rebuilt to become, by 1990, the showcase of what a developing economy ought to look like. (See Edwards and Edwards 1987, Ramos 1986, and Foxley 1983. Corbo and Solimano 1991 offer an excellent perspective on the entire experience.) But disinflation was slow, even though unemployment increased sharply. The primary reason was automatic wage increases resulting from full backward-looking indexation provided for by law.

After the initial orthodox stabilization, the next step was an attempt to disinflate by using the exchange rate as a nominal anchor. The government first implemented a preannounced tablita of exchange rate depreciation and then fixed the exchange rate in 1979 , despite an inflation of 30 percent. But as equations 9 to 11 show, with backward-looking indexation, a fixed exchange rate will lead to real appreciation and consequently to unemployment.

The fixed rate was maintained until 1982, resulting in growing real exchange rate appreciation and contributing to Chile's subsequent debt crisis. The fixed exchange rate, combined with a budget surplus and tight money, did succeed in slowing inflation, but because of the backward-linked indexation of wages, the decline in inflation was slow and real wages started rising. (See Edwards and Edwards 1987 and Corbo 1985 on the interaction between disinflation and real wage gains.) By 1982 the overvaluation in conjunction with massive external shocks made an exchange rate collapse certain. The actual abandonment of fixed rates (amid the debt crisis of 1982) was followed by major exchange rate depreciation and the prospect of renewed inflation.

The 1980s. Following the collapse of the fixed-rate regime, very tight monetary policy and a cyclically adjusted budget surplus forced a deep depression of economic activity. Real GNP declined by 14 percent in 1982 and by another 1 percent in 1983.

Unemployment, including a government work program that paid a fraction of market wages, soon accounted for more than 30 percent of the labor force. In the subsequent years, recovery gradually brought down the record unemployment, but until the late 1980 s, unemployment was high enough to keep a firm lid on wage increases and hence on inflation, despite a significant real depreciation of the currency. Even with the collapse of the exchange rate and the real depreciation between 1981 and 1988, inflation never went back to the high levels of the 1970 s, but rather settled in the 15 to 25 percent range.

The government "de-indexed" the economy in 1982, abolishing the formal and legal obligation to pay wage increases of at least the past rate of inflation (see Corbo and Solimano 1991). But, de facto, backward-looking indexation continued to be largely practiced in the private sector. Falling oil prices after 1984 helped cushion the exchange rate depreciation's inflationary impact. 
Unemployment was certainly not the only factor in maintaining inflation stability. Increasingly, the government succeeded in establishing a consensus around economic policy. It came to be believed, more so after unemployment had come down from peak levels, that a demand-driven program of recovery could result in renewed inflation and chaos. That view was reinforced by the unhappy inflationary experience in other Latin American countries, notably Argentina, Brazil, and Peru.

Seigniorage. Table 7 shows that government revenue from the printing of money was quantitatively unimportant in the 1980 s. Seigniorage was more important in earlier periods, in particular amounting to 17 percent of gross domestic product (GDP) in 1973, and remaining close to 5 percent of GDP through 1978. But there is no reason to think that the need for seigniorage played any significant role in the maintenance of moderate inflation in Chile after 1982, especially given the massive fiscal effort that was undertaken during that period.

The 1990 transition. Chile's success in institutionalizing conservative policies is most apparent in the transition to a democratic government in 1990. This was a natural time to fear that the opposition government, more open to the concerns of labor and the left, might quickly give in to pressures for spending and expansion. The risk posed by such policies was all the more real in that Chile had by 1989-90 been taken to the threshold of full employment and inflation acceleration by Pinochet's overheating of the economy. The transition was then an obvious point at which expectations of inflation and institutional instability might return and lead to an escalation of inflation.

Against a background of an acceleration of inflation, the incoming government took a firm stand: in the campaign they assertively endorsed highly conservative economic management. Once in office, they actually practiced it. The year 1990 was one of slower growth, necessary to cool off the economy and set the stage for sustained and stable growth in the years to come. Inflation did rise in the calendar year to 27 percent. But by December the growth-recession had done its work, and inflation rates had been pushed down sharply. The point had been made that inflation at 20 to 25 percent was acceptable, but open-ended inflation was not.

The transition was marked by an important institutional innovation. An independent central bank was established whose legal charter made it responsible for monetary stability and the normal functioning of the payments mechanism. Growth and full employment were not made part of its objectives. The creation of an independent central bank is widely viewed in Latin America today as the key step in stopping inflation-in Chile it was more the final step in assuring that a disinflation process was locked in.

Throughout the 1980 s, Chile never achieved inflation in the single digit range except just before the 1982-83 depression. Today in Chile there appears to be a 
political economy equilibrium with broad support. Inflation in the 15 to 20 percent range is acceptable, but any acceleration will be resisted, if necessary, with an unpopular slowdown. The equilibrium appears also to include the recognition that rapid disinflation to below, say, 10 percent would involve unemployment at levels that are not worth the price.

\section{Mexico}

Mexico, like many other countries, entered the moderate-inflation range during the first oil shock, in 1974. It stayed in that range through 1981, having had to move to a floating exchange rate in 1976. Despite its booming oil exports, Mexico ran large balance of payments and budget deficits at the end of the 1970 s and the beginning of the $1980 \mathrm{~s}$, using real exchange rate appreciation to help keep the lid on inflation.

In the early 1980s Mexico fell apart. Gross mismanagement in the public sector in the late 1970 s and early 1980 s, exchange rate overvaluation, and excessive indebtedness caused a collapse in 1982. The rest of the decade was devoted to rebuilding the country. Real wages fell dramatically as real depreciation was required to finance debt service and capital flight. Growth disappeared. Inflation exploded on two occasions-in 1983, in the aftermath of a typical election-year expansion, and again in 1987-88 (see figure 4).

The reconstruction of financial stability started in the administration of $\mathrm{Mi}$ guel de La Madrid (1982-88). Noninterest budget surpluses were built up (table

Figure 4. The Rate of Inflation in Mexico, 1980-92

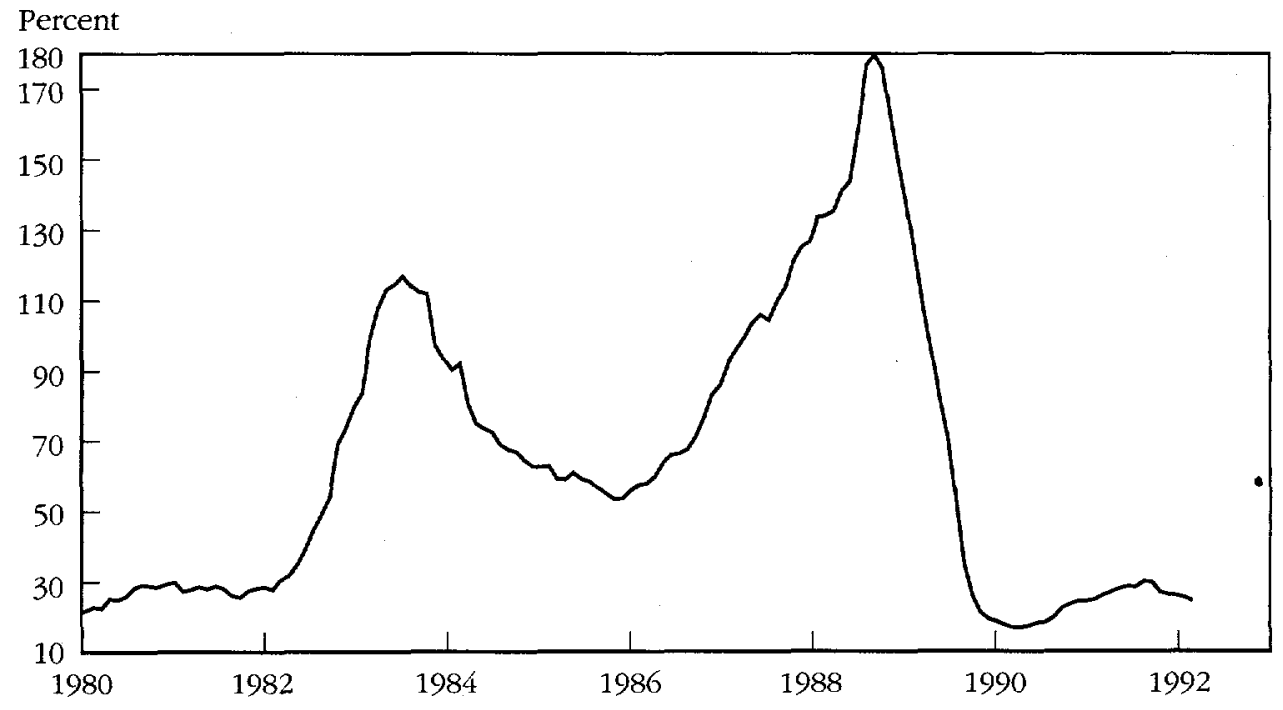

Note: The rate of inflation is measured by the change in the 12-month consumer price index. Data are monthly from January 1980 to February 1992.

Source: International Monetary Fund, International Financial Statistics (various issues). 
Table 8. Stabilization in Mexico, 1985-90

\begin{tabular}{lcccc}
\hline Indicator & $1985-87$ & 1988 & 1989 & 1990 \\
\hline Growth rate of real GDP (annual percent) & 0.2 & 1.3 & 3.1 & 3.9 \\
Inflation rate (annual percent) & 94 & 159 & 20 & 29 \\
Primary budget surplus (percentage of GDP) & 3.2 & 8.1 & 8.3 & 7.5 \\
Real interest rate (annual percent) & -3.3 & 34 & 20.3 & 12.5 \\
Real exchange rate index (1980-82 = 100) & 73 & 77 & 74 & 70 \\
Seigniorage (percentage of GDP) & 2.8 & 1.6 & 0.4 & 1.2 \\
\hline
\end{tabular}

a. $1986-87$.

Source: International Monetary Fund, International Financial Statistics (various issues); Morgan Guaranty (various issues); Government of Mexico data.

8) to finance domestic and external debt service in a noninflationary fashion. Inflation control remained the biggest challenge. The lessons of Argentina, Brazil, Israel, and Peru were closely studied. It was concluded that incomes policy and price freezes worked for a while in Argentina, Brazil, and Peru but succeeded in the longer term only with fiscal consolidation, as in Israel. The right lessons were drawn: that disinflation without fiscal discipline was unsustainable and that disinflation without incomes policy, relying solely on tight money and tight budgets, would be unnecessarily expensive.

The Mexican disinflation program, the Pacto, was initiated in December 1988 and is still under way. The Pacto is a tripartite agreement among the government, unions, and business. The public sector committed itself to fiscal discipline and to specified policies for the exchange rate and public sector prices. As a counterpart, there were agreements for wages and private sector prices. The program was rounded out by pursuing an aggressive trade liberalization that had started even earlier.

Key features of the Pacto were wage agreements that kept a very firm lid on wage increases and an exchange rate policy that reduced the rate of depreciation. From 1989 until mid-1990, the exchange rate was depreciated by 1 peso a day, corresponding to an annual depreciation rate of about 15 percent. Subsequently, the rate of depreciation was cut to 0.8 pesos a day and, more recently, to 0.4 pesos a day. The exchange rate policy was designed to contribute to disinflation. Interestingly, for a while it did not lead to overvaluation, as it did in the Chilean and many other cases. One reason was surely that the wage policy cut decisively into wage inflation. Control of public sector prices, in some areas at the expense of serious misalignment, similarly contributed to maintaining low inflation.

The exchange rate and wage policy were sustained by a very tight monetary policy, reflected in realized real interest rates that were exceptionally high. A decisive decline in real interest rates was achieved when the Mexico Brady debt deal was reached. On the budget side, a large primary surplus was maintained throughout.

The combination of high real interest rates and a tight budget put pressure on 
growth: until 1989 there was practically no growth. But more recently, largely as a result of declining real interest rates, rising real wages, and a gain in confidence, growth has picked up.

Seigniorage. Seigniorage revenue has been small since the inauguration of the Pacto, but in earlier years, after the onset of high inflation, seigniorage amounted typically to 4 to 6 percent of GDP and to about a quarter of total government revenue. Seigniorage was especially large in 1982 and 1983 , the years that inflation jumped from the moderate to high range. Mexico's heavy dependence on seigniorage through 1984 meant that the reduction of inflation required a large fiscal effort, as indeed was made in the second half of the $1980 \mathrm{~s}$.

The next challenge. Mexico, like Chile, has succeeded in forming a consensus around conservative macroeconomic policies and microeconomic reforms. The next question is whether these policies can be carried a step further to bring inflation all the way down and to sustain a fixed exchange rate with the United States. Achievement of a free trade agreement with the United States would surely provide policymakers with a credibility bonus that would help make a fixed rate sustainable.

\section{Colombia}

Colombia is the moderate-inflation country par excellence: it entered the moderate-inflation range in 1973 and has been there since, with the brief exception of 1977, when inflation rose above 30 percent (figure 1). (For accounts of Colombian economic policy, see World Bank 1984, Urrutia 1989, and Hommes 1990.) Colombia's growth performance since 1973 has been good, especially by Latin American standards, and the country avoided rescheduling its debt during the debt crisis. During this period, 30 percent has become a red line for inflation: policy swings into action when the line is about to be breached, as in 1977 and 1990.

Colombia introduced a crawling peg exchange rate in 1967 as part of an export-oriented package to revive growth. Despite the crawling peg and the introduction of indexation of both deposits and loans in the housing finance system in 1971, inflation stayed low until 1971. By 1973 Colombia was in the moderate-inflation range, as were many other countries affected by the worldwide boom and commodities inflation, which included coffee. But Colombia was there to stay, with the assistance of mechanisms for living with inflation: the crawling peg; indexation of the system of housing finance; and indexation of tax brackets and the cost basis for asset taxation, introduced in a 1979 tax reform. The Musgrave Commission, which reported before the 1974 tax reform, recommended against recognizing the distinction between nominal and real returns on assets on the grounds that this would weaken the political will to fight inflation.

The jump in inflation in 1977 is associated with a coffee and external payments boom in 1976. Coffee prices virtually doubled, and money growth was 
allowed to increase. At the beginning of 1977 , a stabilization program was put in place in which fiscal and monetary policy were tightened and devaluation slowed down. By the end of 1977 the program had virtually stopped inflation. This was the first of several episodes in which the upper bound of 30 percent was established for acceptable inflation.

Colombia's economic performance during 1978-82 (the Turbay administration; for data on 1980-90, see table 9) has much in common with that in the rest of Latin America: the government budget moved from a small surplus in 1978 to a deficit of 7.6 percent of GDP in 1982, the real exchange rate appreciated, the current account deteriorated dramatically, and growth slowed. Both the appreciation and the collapse of coffee prices contributed to the worsening of the current account. Although the tax share of GNP increased during this period, expenditures increased more rapidly. The ratio of debt to GDP increased from 28 percent in 1980 to 44 percent in 1985.

A major adjustment program was undertaken in 1984, and over the following two years the budget deficit was reduced by nearly 7 percent of GNP. This reduction was accomplished through increased revenues (obtained in part through tougher collection), reductions in public employment, and reduced public enterprise deficits. At the same time, the rate of depreciation of the exchange rate was sharply increased, although there was no step devaluation. The tightening of fiscal policy moderated the impact of devaluation on inflation. In addition, the government liberalized imports. The real lending interest rate was increased, but there is no other sign in the data of a tightening of monetary policy.

The main aims of the 1984 stabilization program were to end the balance of payments crisis and restore growth. Both these goals were achieved. The adjustment program, aided by the recovery of growth in the world economy, suc-

Table 9. Macroeconomic Performance in Colombia, 1980-90

\begin{tabular}{|c|c|c|c|c|c|c|c|}
\hline \multirow[b]{3}{*}{ Year } & \multirow{2}{*}{\multicolumn{3}{|c|}{ Annual percentage change }} & \multicolumn{3}{|c|}{ Percentage of GDP } & \multirow{3}{*}{$\begin{array}{c}\text { Real } \\
\text { exchange } \\
\text { rate index } \\
(1986=100)\end{array}$} \\
\hline & & & & \multirow[b]{2}{*}{$\begin{array}{c}\text { Budget } \\
\text { deficit }\end{array}$} & \multirow{2}{*}{$\begin{array}{l}\text { Current } \\
\text { account } \\
\text { surplus }\end{array}$} & \multirow[b]{2}{*}{$\begin{array}{l}\text { Seign- } \\
\text { iorage }\end{array}$} & \\
\hline & $\begin{array}{r}\text { Real } \\
\text { GDP }\end{array}$ & $C P I$ & $M 1$ & & & & \\
\hline 1980 & 4.1 & 26.6 & 27.9 & 2.5 & 0.4 & 2.8 & 73.1 \\
\hline 1981 & 2.3 & 27.5 & 19.9 & 6.1 & -6.7 & 2.4 & 70.7 \\
\hline 1982 & 1.0 & 24.6 & 25.4 & 7.6 & -11.3 & 1.7 & 65.6 \\
\hline 1983 & 1.6 & 19.7 & 29.7 & 7.5 & -10.8 & 1.7 & 67.3 \\
\hline 1984 & 3.4 & 16.2 & 23.4 & 6.3 & -7.6 & 2.0 & 71.9 \\
\hline 1985 & 3.1 & 24.0 & 28.2 & 3.5 & -4.9 & 1.4 & 92.4 \\
\hline 1986 & 5.8 & 18.9 & 22.8 & -0.6 & 1.6 & 1.7 & 100.0 \\
\hline 1987 & 5.4 & 23.3 & 33.0 & 1.9 & 0.2 & 1.9 & 99.7 \\
\hline 1988 & 3.6 & 28.1 & 25.8 & 2.1 & -1.0 & 1.6 & 97.7 \\
\hline 1989 & 3.3 & 25.9 & 29.0 & 1.8 & -0.4 & 1.8 & 105.0 \\
\hline 1990 & 3.7 & 29.1 & 25.8 & 0.1 & 1.0 & 1.3 & 117.8 \\
\hline
\end{tabular}

Source: World Bank data; International Monetary Fund, International Financial Statistics (various issues). 
ceeded in reducing the balance of payments deficit to a sustainable level. Growth increased from 1984 but remained below the rates of the previous decade. There is little evidence that the government placed much weight on the goal of significantly reducing inflation, and inflation did not decline. Both the rapid devaluation and the continuance of money growth at previous rates ensured that moderate inflation would continue.

Seigniorage. Throughout the moderate-inflation period, seigniorage revenue accounted for a significant share-on average about 20 percent-of total government revenue. That share declined during the 1980s, as tax reforms were implemented and tax collection improved. Inflation stabilization would require an increase in taxes to offset the decline in seigniorage revenue.

Summary. Since 1985 the Colombian economy has been hit by a variety of shocks, particularly to coffee and oil prices. These shocks have led to fluctuations in the balance of payments and inflation, but with fiscal policy being used actively to prevent inflation rising much above 30 percent. However, between 1974 and 1990, no government made the reduction of inflation a high priority, and the economy was well adapted to living with inflation. The Gaviria administration, which came to power in 1990, has appeared more concerned about inflation than its recent predecessors have, perhaps because the inflation rate has been uncomfortably close to 30 percent. The new administration promises a serious attack on inflation, aiming to get the rate down below 15 percent by 1994. With the exchange rate so depreciated and the current account and fiscal deficit in good shape, the government has some room for maneuver. The administration cannot doubt that a concentrated anti-inflationary policy will temporarily reduce growth, but expresses the view that reducing inflation is worth the cost.

\section{Brazil}

In March 1964 a military coup put an end to the constitutional populist regime of João Goulart. In the preceding few years, inflation had risen from a comfortable 20 percent in the late 1950 s to 144 percent. The inflation was fueled by money printing, especially in the first quarter of 1964 . Threatened by economic instability and radical rhetoric, the middle class supported military intervention. The coup was followed by more than a decade of political repression and an economic miracle.

Disinflation. The Economic Action Program of the new government detailed a plan to reduce inflation gradually over three years by tightening fiscal policy and using an incomes policy. Fiscal consolidation reduced the budget deficit from 4.2 percent of GDP in 1963 to only 1 percent in 1966 . Inflation came down rapidly to the moderate-inflation range (see figure 5 and table 10) and without a major impact on growth. 
Figure 5. The Rate of Inflation in Brazil, 1960-80

Percent

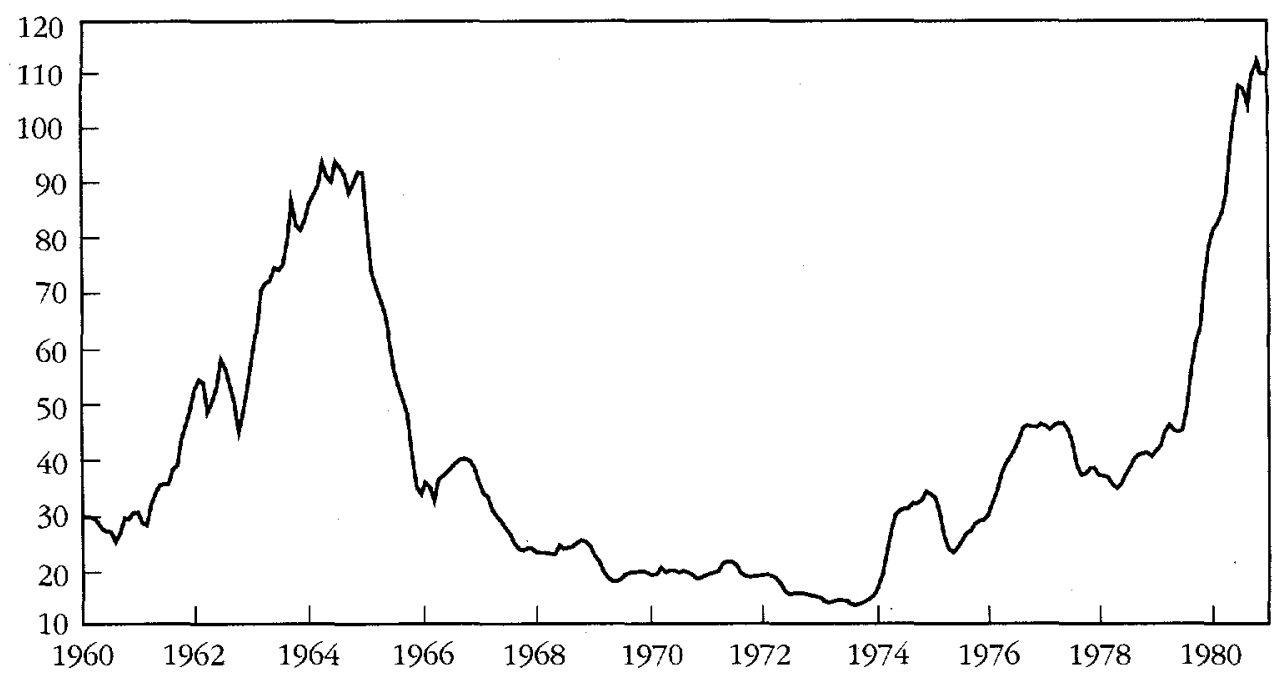

Note: The rate of inflation is measured by the change in the 12-month general price level. Data are monthly from January 1960 to December 1980.

Source: International Monetary Fund, International Financial Statistics (various issues).

A key aspect of the program was a change in the wage indexation formula. From an automatic backward-looking mechanism that built in inertia, the formula was changed to link the current month's wage settlements, lasting 12 months, to "expected" inflation, that is, to a government inflation forecast (see Simonsen 1986, pp. 118-29, and Fishlow 1974). Simonsen (1986, p. 118) notes that the new wage laws were binding, leaving no degrees of freedom in wage setting for the employers or the employees.

The change in the indexation rule operated as a disinflation mechanism be-

Table 10. Inflation and Growth in Brazil, 1960-72

\begin{tabular}{|c|c|c|c|c|c|c|}
\hline Indicator & $1960-63$ & 1964 & 1965 & 1966 & 1967 & $1968-72$ \\
\hline $\begin{array}{l}\text { Rate of inflation (annual } \\
\text { percent) }\end{array}$ & 45 & 92 & 66 & 41 & 31 & 23 \\
\hline $\begin{array}{l}\text { Growth rate of GDP (annual } \\
\text { percent) }\end{array}$ & 6.9 & 2.9 & 2.7 & 5.1 & 4.8 & 12.9 \\
\hline $\begin{array}{l}\text { Budget deficit (percentage } \\
\text { of GDP) }\end{array}$ & 3.7 & 3.2 & 1.6 & 1.1 & 1.7 & 0.5 \\
\hline Seigniorage (percentage of GDP) & $5.4^{\mathrm{a}}$ & 5.0 & 4.7 & 2.1 & 1.9 & 2.0 \\
\hline $\begin{array}{l}\text { Seigniorage as a percentage of } \\
\text { government revenue }\end{array}$ & $40.0^{a}$ & 39.3 & 34.9 & 18.3 & 19.8 & 17.8 \\
\hline
\end{tabular}

a. $1962-63$.

b. Seigniorage to total government revenue (including seigniorage).

Source: Simonsen (1974); International Monetary Fund, International Financial Statistics (various issues); Cardoso and Fishlow (1990). 
cause productivity allowances and inflation forecasts were entirely up to the government. ${ }^{6}$ The productivity allowances for 1965, 1966, and 1967 were, respectively, 25,10 , and 15 percent, but the actual cost of living increases were 46,41 , and 24 percent, respectively, for those years. As a result real wages declined by 25 percent in this period (see Simonsen 1986, p. 119). In terms of our earlier discussion, the deceleration in wage increases provided the initial slowdown in inflation. Thus labor paid for the disinflation process, at least initially.

With almost every aspect of policy, including fiscal policy, pointing in the same direction, it is hard to identify the key element in the disinflation. Three factors contributed: the change of political and economic regime and the accompanying repression of labor militancy; the sharp tightening of the budget; and the change in the indexation formula that effectively produced a disinflation of costs through legislation. It is interesting to note that the disinflation did not cause a recession. However, some impact of the disinflation is evident from the fact that growth was sharply higher both before and after the disinflation than during the period.

Three other points are worth noting. First, there was really no monetary crunch, except possibly in 1966, after disinflation was already well under way. Money growth remained high in 1965, well above the inflation rate, thereby permitting the rebuilding of real money balances to a level consistent with lower inflation. The absence of a monetary crunch in that year suggests that fiscal policy, the credibility of the military government, and perhaps most of all the change in the indexation rule must be given the credit for disinflation.

Second, there was no attempt to move inflation below the moderate-inflation range. The Brazilian stabilization thus presents an early example-and perhaps a warning-of the type of problem that is being faced at present by such countries as Bolivia, Israel, and Mexico, which have successfully reduced extreme inflations but not moved below the moderate-inflation range.

Third, seigniorage accounted for an important share of total government revenue in the early $1960 \mathrm{~s}$, as the inflation accelerated. Seigniorage declined as fiscal consolidation took place but nonetheless still amounted to more than onesixth of government revenue after inflation declined. It continued to represent somewhere between 15 and 30 percent of government revenue through the next decade.

In 1968-70, once disinflation had been put in place, structural reform helped support the program for growth. The exchange rate regime became a crawling peg, and there were frequent minidevaluations. Trade was in some measure

6. The exact formula, as reported in Simonsen (1986, p. 119), was

$$
w=p_{-1}^{*}+0.5 \pi_{i}^{e}+0.5\left(w_{-1}-p_{-1}^{*}+w_{-2}-p_{-2}^{*}\right)+z_{t}
$$

where $p^{*}$ is the cost of living at the end of the year and all variables are in logs except for the inflation forecast, $\pi^{e}$, and the productivity growth allowance, $z_{t}$. 
liberalized by streamlining tariffs and quotas and by putting in place a system of duty rebates for exports. Tax collection was radically improved: receipts were raised from only 15 percent of GDP in the mid-1960s to almost 25 percent in the early 1970 s. These measures helped prolong the boom by preventing the two most common causes of policy reversals: foreign exchange bottlenecks and problems of public finance.

By the early 1970s Brazil had learned to live with inflation, thanks to pervasive indexation (see especially the discussion in Fishlow 1974). In fact, there was a certain pride in managing inflation without tears. ${ }^{7}$ Thus Simonsen (1974, p. 118) notes: "A respectable current of economic thinking admits today that 15 percent inflation a year, in the actual conditions of Brazil, represents a situation far less serious than 5 to 6 percent inflation in a country not equipped to deal with inflation, that is without pervasive indexation and a crawling peg exchange rate policy."

Resurgence of inflation. The reduced inflation of the 1964-68 stabilization program was carried into the early 1970 s. The economic miracle produced record growth rates with falling rates of inflation. In fact, in 1973 "official" inflation fell to only 12.7 percent, and real inflation was not much higher. Pervasive indexation of wages-the formula for which had again become backward-looking - and especially of public sector prices and financial assets ensured that living with inflation was no problem at all. In fact, it was so little a problem that inflation was not taken very seriously even when it increased to 100 percent.

The key fact is that when inflation came down to 20 percent, and when public sector deficits and the misalignment of relative prices had been cured, the doors were open to an extraordinary boom. And the government was in no mind to do anything-such as trying to reduce inflation-that could stop the boom. The early 1970 s, before the oil shocks, would have been the time to make the institutional and policy changes that might have taken inflation all the way down to industrial-country levels, but the problem was not sufficiently pressing for the government to want to make the attempt.

The resurgence of inflation in Brazil occurred in the mid-1970s in the context of an overheating economy-the average growth rate for the period 1967-74 was 10 percent a year! The oil shock in combination with backward-looking indexation-which causes difficulties in the face of supply shocks-rapidly increased inflation. The following table shows the pattern of a doubling of inflation rates every few years (International Monetary Fund, International Financial Statistics [various issues]):

$\begin{array}{lcccc} & 1970-75 & 1976-79 & 1980-82 & 1983-85 \\ \text { Inflation rate (average annual } & 21.4 & 44.3 & 97.8 & 188.3\end{array}$
percent)

7. There was a similar attitude to living with inflation in Israel at that time. 
A key ingredient in the speedup was the progressive shortening of indexation intervals.

The chief lessons from Brazil's experience concern the roles of indexation, demand management, and the need to deal opportunely with inflation. In effect, deindexation of wages was used in the 1964-66 stabilization (in combination with political and wage repression) to sharply decelerate inflation without creating massive unemployment. But indexation was reintroduced, and because it was backward-looking, it served to accelerate inflation when supply shocks appeared in the 1970s (see Dornbusch, Sturzenegger, and Wolf 1990).

Two different types of opportunity were missed in dealing with inflation. First, when conditions were booming in the early 1970s, the government could have attempted to move the inflation rate down below the moderate-inflation range without much fear of a recession. And second, as inflation accelerated in the first oil shock, Brazil could have implemented policies to try to keep inflation in the moderate range. It did neither, and inflation later exploded, with consequences that are still being suffered.

\section{Republic of Korea}

Korea has a long inflationary history (Cole and Park 1983, chapter 8 , describe the history of inflation since the 1860s), which includes an increase of more than 2,300 percent in the wholesale price index in July and August 1945 as price controls were removed at the end of World War II. In the period after the start of the Korean miracle, inflation was in the double digits in every year between 1963 and 1981, except for 1973 (see figure 6 for inflation in the consumer price index [CPI] for 1971-91). In 1973 CPI inflation was 3.0 percent, while the GDP deflator increased by 13.5 percent. The deflator typically increased more rapidly than the CPI; in turn, the CPI usually rose more rapidly than the WPI (wholesale price index). This pattern, familiar from Japan, results from the rapid increase in real wages and hence the price of services. After 1982, the annual inflation rate was comfortably in single digits. Using the CPI as a measure of inflation, Korea suffered two spells of moderate inflation in the period since 1971: 197476 and 1979-81. Measuring inflation by the GNP deflator, Korea was in the moderate-inflation range between 1975 and 1981.

Either way, Korea is one of the few developing countries that has moved decisively from moderate to low inflation. We examine two questions: Why was inflation in the moderate range up to 1981, and how did Korea reduce its inflation rate so decisively?

The 1964 devaluation marked the definitive start of the Korean export promotion drive and the modern Korean growth phenomenon. For the period 1965-71, with growth averaging just under 10 percent and inflation just over 10 percent a year, there was not much reason to worry about the latter. Cole and Park (1983, p. 213) describe $1965-71$ as a golden age, to which foreign capital inflows contributed. Despite the double-digit inflation, there was no wage indexation. Nevertheless, productivity gains produced rising real wages. Inflation 
Figure 6. The Rate of Inflation in the Republic of Korea, 1971-92

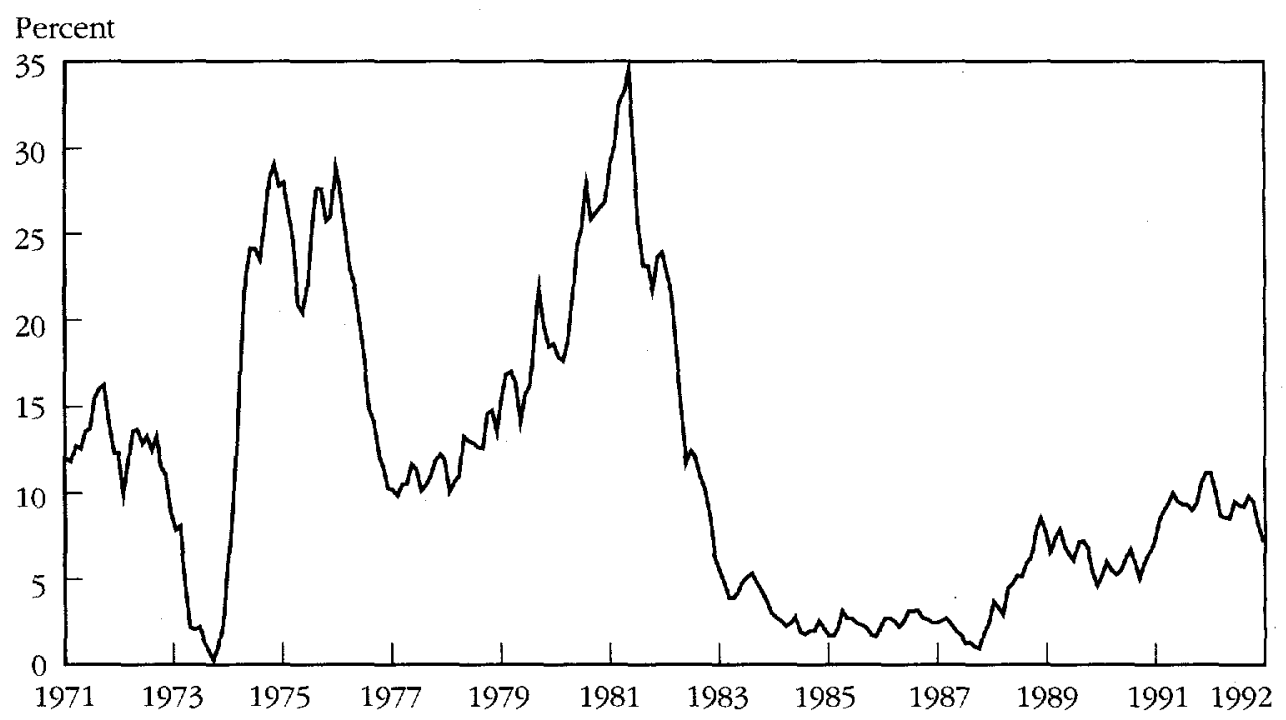

Note: The rate of inflation is measured by the change in the 12-month consumer price index. Data are monthly from January 1971 to February 1992.

Source: International Monetary Fund, International Financial Statistics (various issues).

was not regarded as a policy problem, particularly because it showed no sign of getting out of control.

Korea's first moderate-inflation episode in the modern high-growth era came with the first oil shock. The government responded to the shock by raising taxes on oil but otherwise going for growth by expanding investment, exports (including labor) to the Middle East, and foreign borrowing. The nominal exchange rate, which had been pegged in 1972, was devalued by 20 percent at the end of 1974 , and fiscal and credit policies were expansionary.

The decision to emphasize growth during the first oil shock was also a decision not to fight inflation. On the cost side, the jump in inflation between 1973 and 1974 can be traced to higher import prices and to wage inflation. In the absence of restrictive policy, and because unemployment increased very little, wage inflation continued at 30 percent in 1975 and 1976. The fixed exchange rate and declining import prices, by contrast, tended to reduce the inflation rate.

The growth policy was extremely successful, but the high inflation of 1974 and 1975 , combined with a fixed exchange rate, led to a tightening of credit in 1976 , as well as a shift to a more restrictive fiscal policy. In addition, price controls were imposed on both consumer and producer goods. Inflation slowed appreciably in 1976 and 1977, while growth increased, but wage inflation did not decline, in part because of Middle Eastern demand for Korean labor. In 
1977 the current account was in surplus, and the Korean approach to the oil shock appeared to be entirely successful.

After 1977, however, Korea began to display Latin American symptoms: the currency was increasingly overvalued, foreign borrowing was growing, and inflation was increasing. Despite some tightening of monetary and fiscal policy in late 1978, the investment drive in heavy and chemicals industries pushed the rate of investment above 30 percent.

For the first time in the modern growth era, inflation became a central concern of policy. Nam (1984) explains:

As inflation accelerated, it became clear that sustained economic growth is simply impossible without curbing inflation. Weakening export competitiveness, unproductive activities of businesses preoccupied with inflationary gains, and the growing frustration of workers confronting a widening disparity in the distribution of income and wealth all indicated that growth potential was being seriously undermined by chronic inflation.

Foremost among the reasons to fight inflation was the labor unrest caused by the increasing visibility of speculative incomes, especially in real estate and the stock market. The argument tying export performance to inflation appears to assume a fixed exchange rate; perhaps it is being implicitly argued that devaluation would have worsened inflation. In any case, by the end of the 1970 s, the Korean government had decided to fight inflation.

In April 1979, before the second oil price shock, the government adopted the Comprehensive Measures for Economic Stabilization program (Nam 1984; Corbo and Nam 1992a). The plan was to cut current government expenditures by 5 percent and to cut back on investment. (Corbo and Nam 1992b show a reduction in the full employment deficit of about 1.5 percent of GNP in 1979.) Interest rates were raised and subsidized lending reduced. In addition, a price stabilization program was announced for necessities, including measures to expand domestic supply, improve distribution of foodstuffs, and liberalize imports.

This program was derailed by both the second oil price shock and the assassination of President Park. The oil price shock added to the effects of poor harvests in 1978 and 1979 to worsen the balance of payments. High world interest rates and the deteriorating debt situation meant that this time Korea could not go for growth and borrow its way through the second oil shock. The oil price increase was passed on to domestic prices directly. There was also a widespread diagnosis that the drive in the late 1970s for heavy and chemicals industries had been a mistake and that the economy needed trade and domestic liberalization.

Early in 1980 the won was devalued by 20 percent and shortly thereafter was tied to a basket rather than the dollar. To counteract the inflationary effects of devaluation, interest rates were increased by 5 to 6 percent; the loan rate increased from 19 percent to 25 percent. The aggregate thrust of fiscal policy was 
Table 11. Inflation and Other Indicators for Korea, 1978-84

\begin{tabular}{|c|c|c|c|c|c|c|c|}
\hline Indicator & 1978 & 1979 & 1980 & 1981 & 1982 & 1983 & 1984 \\
\hline GDP growth rate & 9.7 & 7.4 & -2.0 & 6.7 & 7.3 & 11.8 & 9.4 \\
\hline $\begin{array}{l}\text { Inflation } \\
\text { CPI } \\
\text { GDP deflator }\end{array}$ & $\begin{array}{l}14.4 \\
22.7\end{array}$ & $\begin{array}{l}18.3 \\
19.8\end{array}$ & $\begin{array}{l}28.7 \\
24.0\end{array}$ & $\begin{array}{l}21.3 \\
17.0\end{array}$ & $\begin{array}{l}7.2 \\
6.9\end{array}$ & $\begin{array}{l}3.4 \\
4.9\end{array}$ & $\begin{array}{l}2.3 \\
4.0\end{array}$ \\
\hline $\begin{array}{l}\text { M2 growth } \\
\text { Credit growth }\end{array}$ & $\begin{array}{l}35.0 \\
45.4\end{array}$ & $\begin{array}{l}24.6 \\
35.7\end{array}$ & $\begin{array}{l}26.9 \\
40.6\end{array}$ & $\begin{array}{l}25.0 \\
31.1\end{array}$ & $\begin{array}{l}27.0 \\
25.1\end{array}$ & $\begin{array}{l}15.2 \\
16.0\end{array}$ & $\begin{array}{r}7.7 \\
13.1\end{array}$ \\
\hline $\begin{array}{l}\text { Budget deficit } \\
\text { (percentage of GDP) } \\
\text { Seigniorage }\end{array}$ & 2.5 & 1.4 & 3.2 & 4.6 & 4.3 & 1.6 & 1.4 \\
\hline (percentage of GDP) & 3.0 & 2.1 & -0.6 & -0.9 & 1.9 & 0.4 & 0.2 \\
\hline Nominal exchange rate & 0.0 & 0.0 & 36.3 & 6.2 & 6.9 & 6.2 & 4.0 \\
\hline $\begin{array}{l}\text { Current account deficit } \\
\text { (percentage of GDP) }\end{array}$ & 2.2 & 6.4 & 8.5 & 6.7 & 3.6 & 2.0 & 1.5 \\
\hline $\begin{array}{l}\text { Nominal wages } \\
\quad \text { (growth rate) } \\
\text { Productivity (growth rate) }\end{array}$ & $\begin{array}{l}35.0 \\
11.6\end{array}$ & $\begin{array}{l}28.3 \\
15.3\end{array}$ & $\begin{array}{l}23.4 \\
10.7\end{array}$ & $\begin{array}{l}20.7 \\
16.8\end{array}$ & $\begin{array}{r}15.8 \\
7.3\end{array}$ & $\begin{array}{l}11.0 \\
12.9\end{array}$ & $\begin{array}{r}8.7 \\
10.0\end{array}$ \\
\hline $\begin{array}{l}\text { Import prices } \\
\text { All items } \\
\text { Petroleuma }\end{array}$ & $\begin{array}{r}4.1 \\
-4.6\end{array}$ & $\begin{array}{l}26.6 \\
47.0\end{array}$ & $\begin{array}{l}27.5 \\
12.8\end{array}$ & $\begin{array}{r}2.4 \\
-4.1\end{array}$ & $\begin{array}{l}-5.3 \\
-2.8\end{array}$ & $\begin{array}{l}-4.2 \\
-3.3\end{array}$ & $\begin{array}{l}0.3 \\
0.1\end{array}$ \\
\hline
\end{tabular}

a. Chemicals, petroleum, and coal products.

Source: International Monetary Fund, International Financial Statistics (various issues); Government of Korea (1990).

essentially unchanged, but its microeconomic details changed from supporting heavy industry toward supporting small and medium-size firms and residential construction. A poor rice crop and the collapse of external markets made 1980 the first year of negative growth in more than two decades, while the price shocks kept inflation high. ${ }^{8}$ The sharp decline in agricultural output alone reduced GNP by 4 percent.

There is little sign in table 11 of a tightening of fiscal and monetary policies between 1979 and 1982, except for the reduction in seigniorage revenue. Interest rates were raised in 1979 and money growth declined, but the real volume of credit expanded in 1980 and 1981. Fiscal policy tightened only in 1981 (see Corbo and Nam 1992b, table 3-8; Aghevli and Marquez-Ruarte 1985, table 8). The extra ingredient was incomes policy: wage increases in the government sector were reduced in 1981 and 1982; by convention, and with the assistance of jawboning, the private sector followed. In addition, a mass education campaign, undertaken at the end of 1980 , "stressed the need for restraining the demand for excessive wage increases and for a higher government purchase price of rice" (Nam 1984). 
Nominal wage growth and inflation continued to decline after 1982, along with the rates of growth of money and credit; at the same time, the Korean growth machine revived. Inflation has stayed low, and, corresponding to the decline in inflation, seigniorage now accounts for only a small share of government revenue.

It took almost three years from the beginning of the comprehensive stabilization program in 1979 until inflation came down to the single digit range. That lag was in large part caused by the massive international shocks, as well as the domestic agricultural shock, that hit Korea between 1979 and 1982. By any standards-and especially by Korean standards- 1980 was a recession year. This invites the question of how much of the recession was the result of antiinflationary policies. To estimate the answer, we would need to specify both the alternative policy and a model to calculate the impact. One alternative would have been to accommodate the inflation, allowing inflation to rise by the extent of the price shocks of 1980 . Such a policy would have produced a smaller recession in 1980 , but we do not have a model that would allow us to calculate the tradeoff between the alternative policies. ${ }^{9}$

Contrasting the results of Korea's economic policies in the 1980-82 period with those of Latin American countries that accommodated the inflation, it is hard to believe there would have been a significant tradeoff over any long period. It is clear also that the authoritarian structure of policymaking in Korea significantly reduced the output sacrifice needed to reduce inflation.

\section{Indonesia}

After extreme inflation and a violent revolution in the mid-1960s, Indonesia was growing fast by 1968 and had single digit inflation by 1971 (table 12 and figure 7). ${ }^{10}$ The stabilization was orthodox, both the budget deficit and monetary growth being reduced rapidly. (For descriptions of the Indonesian economy, see Glassburner 1971, Papanek 1980, Booth and McCawley 1981, Gillis 1984, Gelb and Glassburner 1988, and the regular reports on recent economic developments in the Bulletin of Indonesian Economic Studies.)

The restoration of real balances after the hyperinflation, financial reform, and growing monetization in Indonesia in the period of rapid growth permitted rates of money growth well in excess of the rate of growth of nominal GNP after 1968 and meant that seigniorage typically accounted for about 15 percent of total government revenue. In the early stages of the stabilization, until the end of 1968 , the exchange rate floated; it was then pegged to the dollar, but with large devaluations in 1970 and 1971. Remarkably, capital movements were freed,

9. Corbo and Nam present a wage-price model, but it does not explicitly include monetary and fiscal policy. Unemployment is treated as exogenous, but the estimates of their Phillips curve show only small effects of higher unemployment on inflation.

10. Both GNP and inflation data for this period are of poor quality; the CPI is based on Jakarta prices, but differences in inflation rates in different parts of the country are frequently large. 
Table 12. Inflation and Growth in Indonesia, 1965-72 (percent)

\begin{tabular}{lcccccccc}
\hline Indicator & 1965 & 1966 & 1967 & 1968 & 1969 & 1970 & 1971 & 1972 \\
\hline GDP growth $^{\text {Inflation }}$ & 0.0 & 2.3 & 2.3 & 11.1 & 6.0 & 7.5 & 7.0 & 9.4 \\
& 596 & 636 & 111 & 84 & 10 & 9 & 4 & 26 \\
\hline
\end{tabular}

a. The rate of inflation is the year-end to year-end change in the Jakarta CPI.

Source: GNP growth from International Monetary Fund, International Financial Statistics (various issues); inflation rate from Gillis (1984), p. 237.

and they have remained free since 1970 , despite an adjustable peg exchange rate.

Given its inflationary history, it is easy to imagine that Indonesia could have gone into a prolonged inflation as a result of the oil price shocks. We therefore study the first oil shock episode to discover how it avoided the inflation trap. Because it is an oil exporter, Indonesia's budget benefited from the oil price increase (table 13). It is clear from the table that in Indonesia, as in much of the rest of the world, inflation was on the rise before the oil price shock, which hit only at the end of 1973 . Increasing rice prices-a result of rising import prices, inefficient domestic procurement policies, and a poor domestic crop-were a

Figure 7. The Rate of Inflation in Indonesia, 1961-90

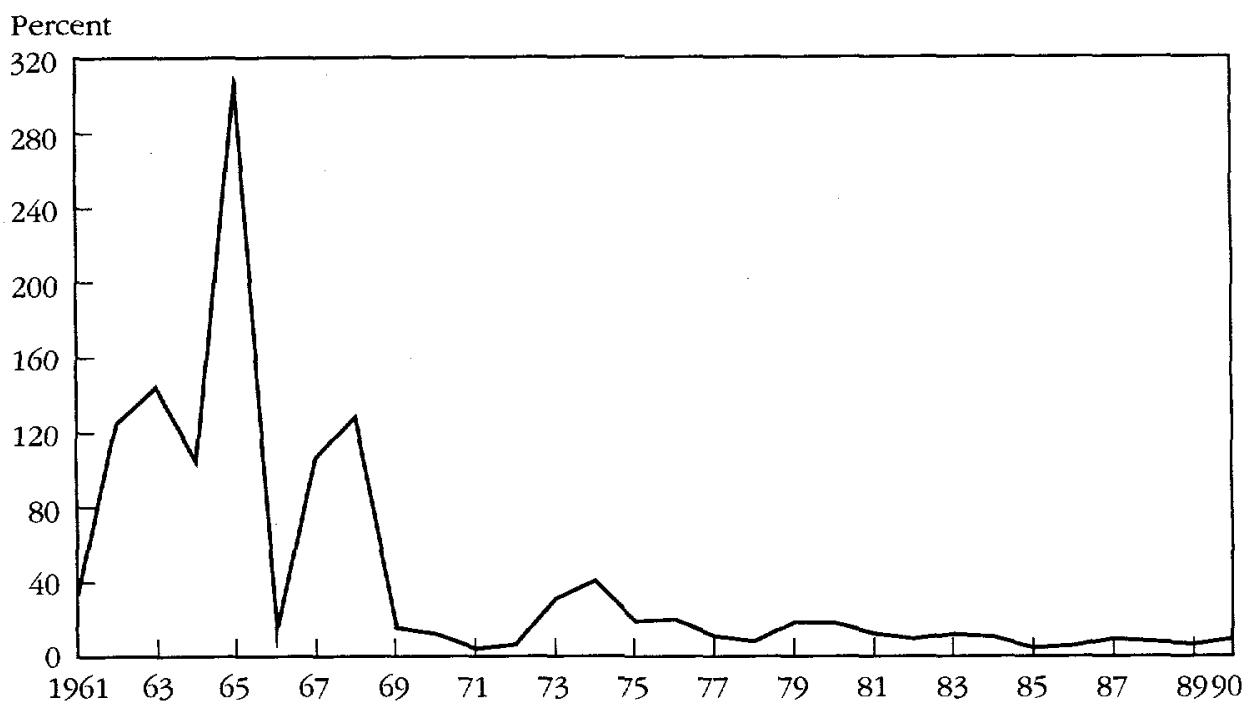

Note: The rate of inflation is measured by the change in the 12-month consumer price index. Data are yearly.

Source: International Monetary Fund International Financial Statistics (various issues). 
Table 13. The Effects of the First Oil Shock in Indonesia, 1972-78 (percent)

\begin{tabular}{|c|c|c|c|c|c|c|c|}
\hline \multirow[b]{3}{*}{ Year } & \multirow{2}{*}{\multicolumn{4}{|c|}{ Annual rate of change }} & \multicolumn{3}{|c|}{ Percentage of GDP } \\
\hline & & & & & \multirow{2}{*}{$\begin{array}{l}\text { Budget } \\
\text { deficit }\end{array}$} & \multirow{2}{*}{$\begin{array}{l}\text { Seign- } \\
\text { iorage }\end{array}$} & \multirow{2}{*}{$\begin{array}{l}\text { Curren } \\
\text { accoun } \\
\text { deficit }\end{array}$} \\
\hline & Real GDP & $C P I$ & $M 2$ & Credit & & & \\
\hline 1972 & 9.4 & 6.5 & 48.6 & 33.7 & 2.7 & 2.7 & 3.0 \\
\hline 1973 & 11.3 & 31.0 & 41.6 & 64.7 & 2.5 & 2.3 & 2.9 \\
\hline 1974 & 7.6 & 40.6 & 40.4 & 41.3 & 1.6 & 2.9 & -2.3 \\
\hline 1975 & 5.0 & 19.0 & 35.2 & 47.6 & 3.9 & 2.2 & 3.6 \\
\hline 1976 & 6.9 & 19.9 & 25.7 & 18.5 & 4.6 & 1.6 & 2.4 \\
\hline 1977 & 8.8 & 11.1 & 25.3 & 45.2 & 2.1 & 1.8 & 0.2 \\
\hline 1978 & 7.8 & 8.1 & 24.0 & 4.5 & 3.5 & 0.7 & 4.5 \\
\hline
\end{tabular}

Source: International Monetary Fund, International Financial Statistics (various issues).

major factor in the 1973 inflation. ${ }^{11}$ Rising export prices, the boom, and accommodating monetary policies added to the inflation.

Indonesia is distinguished from other oil exporters by its relatively careful budget policies. ${ }^{12}$ The budget deficit was not allowed to rise above 5 percent of GNP, even in 1976, when the real price of oil was 15 percent below its 1974 level. Equally important, Indonesia used the oil windfalls mainly to finance investment spending. Thus while government spending was procyclical, it was the investment component that fluctuated most.

A major stabilization program was initiated in April 1974. The monetary measures were conventional: interest rates were raised, reserve requirements were doubled, foreign borrowing was taxed, and credit ceilings were imposed. ${ }^{13}$ Fiscal measures were more complex: sales taxes on luxuries were raised and those on essentials reduced; imports of rice and fertilizer were heavily subsidized; and it was decided to aim for a budget surplus (Arndt 1974). Although Indonesia did not achieve a budget surplus, the deficit never rose out of control, and dependence on seigniorage was reduced.

In 1974 the national oil company, Pertamina, which had borrowed extensively, was unable to service its debts. The government assumed the debts and allocated nearly half of one year's oil revenue to servicing them, thereby in effect using oil revenue to increase net foreign assets at the time when real oil prices were close to peak.

The anti-inflation policy implemented in 1974 gradually took effect during the next two years, although a budget surplus was not achieved. By 1978 the inflation rate was back to single digits. However, the real exchange rate had appreciated since 1973, and a major devaluation was undertaken in November 1978 , both to improve incentives for non-oil exports and to increase the rupiah value of government oil revenue. This devaluation set off another round of

11. This episode is discussed in McCawley (1973).

12. Gillis (1984) interprets the balanced budget rule that has been a principle of policy followed by the long-lasting Indonesian economic team.

13. A 30 percent non-interest-bearing deposit at the central bank was imposed against private sector foreign borrowing except for financing imports and for long-term borrowing. 
inflation, but careful macroeconomic policies kept inflation at 18 percent in 1979 and 1980 , close to 10 percent through 1984 , and in single digits since then.

The Indonesian experience shows a government that both brought hyperinflation under control and prevented prolonged moderate inflation by following mostly orthodox monetary and fiscal policies, with some supply-side fiscal elements thrown in. No doubt Indonesia benefited from being an oil exporter, but as Mexican experience shows, being an oil exporter was not sufficient to avoid the inflationary virus. There was a slight slowdown in growth in 1975 as inflation declined, but, essentially, Indonesia was able to maintain high growth rates even while inflation came down. In 1982 and 1985 there was some sign that counterinflationary policy helped reduce growth-but growth has not fallen below 2 percent a year in the period since 1966 .

\section{Ireland}

Ireland's inflation entered the double-digit range during the 1970 s, when increased oil prices and a tight link to the falling pound sterling were the main sources of higher inflation. The chief mechanism for translating supply shocks into increased inflation was sticky real wages. National Wage Agreements and National Understandings did more to protect real wages and relative wages than to help absorb real shocks without sharply raising inflation. The situation was aggravated by substantial wage gains in the public sector, which made it difficult for the private sector to resist wage inflation. Moreover, exchange rate policy was broadly accommodating. Rounds of inflation were followed by depreciation. And inflation accelerated sharply, reaching more than 20 percent in 198182 (see figure 8 ).

Having pegged to sterling since 1922, Ireland abandoned the currency link with the United Kingdom and joined the Ems in 1979 . Until the early 1980 s the EMS had relatively little effect: frequent realignments were needed because the inflation differentials with Germany and other EMS partners were substantial. In fact, there were seven EMs realignments in the 1980-84 period. But, increasingly, the ems became more of a constraint, or at least was used as such by policymakers. Early 1982 marked the first case of an EMs realignment in which the Irish pound was not devalued (in relation to the European currency unit). The exchange rate peg became progressively firmer.

Among the sources of disinflation was the decline of external inflation. Specifically, Ireland's main trading partners experienced a major decline in their inflation rates, and this decline helped reduce inflation in Ireland. But most of the work was clearly domestic. There was a decisive turnaround on the budget in 1982: after one government fell on the budget issue, the new government returned the same budget and got it passed. Increasingly, the view that fiscal discipline and stable exchange rates were essential ingredients for macroeconomic stabilization gained acceptance. Tight money supported the move to lower inflation.

Inflation stabilization did not come cheaply. As table 14 shows, the unem- 
Figure 8. The Rate of Inflation in Ireland, 1971-91

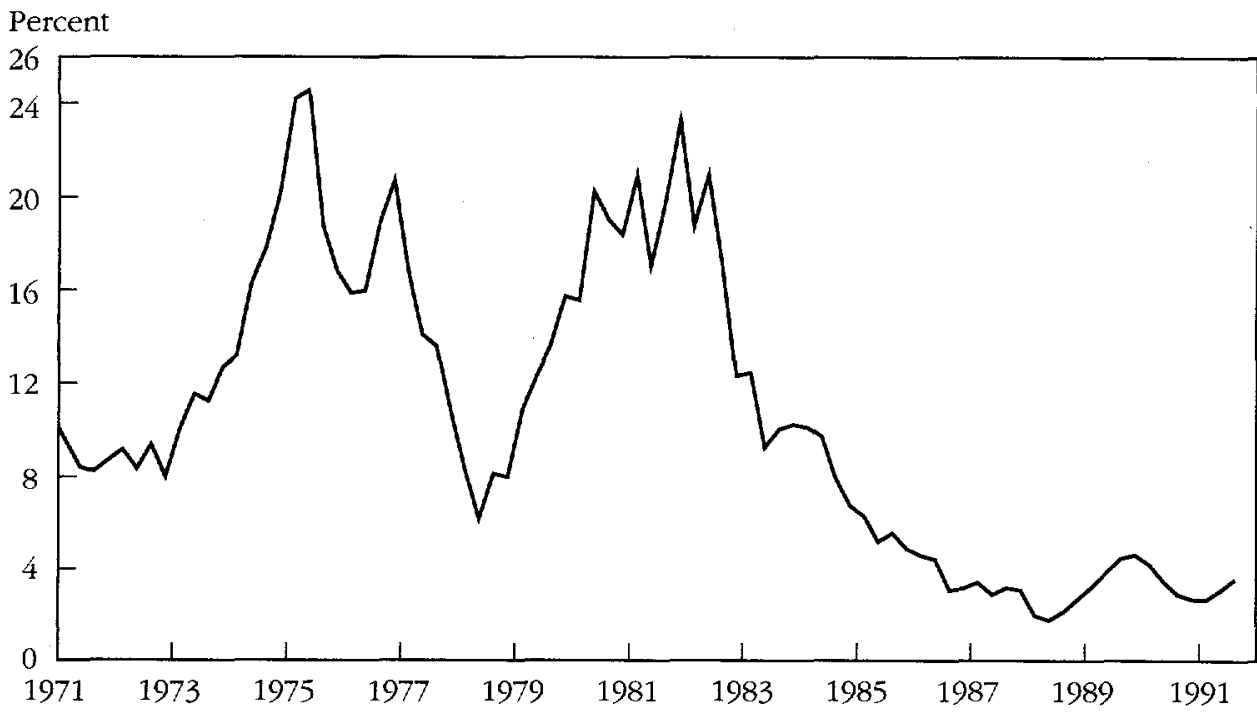

Note: The rate of inflation is measured by the change in the 12 -month consumer price index. Data are quarterly from the first quarter of 1971 to the fourth quarter of 1991.

Source: International Monetary Fund, International Financial Statistics (various issues).

ployment rate rose from 9.5 percent to more than 17 percent between the early 1980 s and 1987. A massive shift in the primary budget from a deficit of 4 to 8 percent to a surplus of 4 percent was behind the sharp cooling off in economic activity. ${ }^{14}$ And the fiscal tightening was accompanied by a major increase in realized real interest rates, a result of both declining inflation and tight money. With a stable exchange rate, budget tightening, and increased real interest, there could be no crowding-in; the outcome was high unemployment.

The unwavering commitment to disinflation did pay off: inflation came down to German levels by the beginning of the $1990 \mathrm{~s}$, after almost 10 years of disinflation. Even then, unemployment remained high and helped reinforce the antiinflationary discipline of monetary and fiscal policy.

An interesting question to which no definitive answer is as yet available is: Did EMS participation help disinflation over and above what monetary and fiscal policy accomplished? ${ }^{15}$ There is no ready evidence of a clear-cut, irreversible change in regime, such as an immediate drop in long-term interest rates reflecting a collapse of inflationary expectations. Rather, disinflation was a day-by-day affair and the question of whether the currency would be devalued was always

14. Seigniorage revenue was small throughout, suggesting that seigniorage cannot have been a significant factor underlying inflation in Ireland.

15. This is the argument Kremers (1990) advances and supports; see, too, Dornbusch (1989). 
Table 14. Stabilization in Ireland, 1980-91 (percent)

\begin{tabular}{lccccc}
\hline Year & $\begin{array}{c}\text { Rate of } \\
\text { inflation }\end{array}$ & $\begin{array}{c}\text { Rate of } \\
\text { unemploy- } \\
\text { ment }\end{array}$ & $\begin{array}{c}\text { Primary } \\
\text { budget } \\
\text { deficita }\end{array}$ & $\begin{array}{c}\text { Seign- } \\
\text { iorage }\end{array}$ & $\begin{array}{c}\text { Real interest } \\
\text { rate }\end{array}$ \\
\hline $1980-82$ & 18.6 & 9.5 & 7.8 & 0.8 & -1.7 \\
$1983-85$ & 8.1 & 15.6 & 4.3 & 0.8 & 4.7 \\
$1986-88$ & 5.2 & 17.5 & -0.9 & 0.5 & 5.9 \\
$1989-90$ & 3.7 & 14.7 & -4.4 & $0.8^{\mathrm{b}}$ & 6.4 \\
1991 & 3.2 & 15.8 & -4.2 & -0.9 & 6.9 \\
\hline
\end{tabular}

a. Percentage of GDP.

b. 1989.

Source; OECD (various issues); International Monetary Fund, International Financial Statistics (various issues).

alive when EMS realignments came up. The claim that EMS membership helped to secure the disinflation is certainly plausible: without the EMS commitment, the government might at a number of points have been more inclined to accommodate inflationary pressures or relent in its restrictive policies-in brief, the EMS commitment served as a nominal anchor for policy.

This claim may well be right, but it must not obscure the basic message: Ireland spent nearly a decade with record unemployment despite an extraordinary shift in monetary and fiscal policy. And even by 1992, unemployment was still extremely high. Although Ireland undoubtedly always had high unemployment, and although it did change the policy regime, there was no obvious credibility bonus for the government.

The Programme for National Recovery. By 1987 inflation had come down substantially, but the cost in unemployment was extremely high. The Programme for National Recovery (PNR) was intended to substitute incomes policy for unemployment as a means of further disinflation. To keep inflation low, exchange rate depreciation had to be avoided, but inflation was still too high to sustain a fixed rate indefinitely. The PNR addressed this issue through an agreement between the Irish Congress of Trade Unions and the Federated Union of Employers that cut rates of wage increases in half. These pay agreements were widely followed in private settlements. A 1989 survey showed that 97 percent of agreements were within the guidelines and that 78 percent of these agreements covered a three-year period. In the public sector the pay agreements paralleled those for the private sector, except that they included a front-end six-month pay pause.

Incomes policy became a powerful means of combining lower inflation with economic recovery at the end of the 1980s. Exchange rate policy fully supported the incomes policy: because the exchange rate on the deutsche mark suffered no further realignment, Ireland now had a hard currency. In 1988 it seemed questionable whether the policy could be called successful. (For a highly pessimistic assessment of Ireland's prospects, written at the trough in 1988, see Dornbusch 
Table 15. Macroeconomic Indicators for Spain, 1979-90 (percent)

\begin{tabular}{|c|c|c|c|c|c|c|c|c|}
\hline & Year & $\begin{array}{l}\text { Rate of } \\
\text { inflation }\end{array}$ & $\begin{array}{c}\text { Real interest } \\
\text { rate }\end{array}$ & $\begin{array}{c}\text { Primary } \\
\text { budget } \\
\text { deficit }^{\mathrm{b}}\end{array}$ & Seigniorage ${ }^{\mathrm{b}}$ & $\begin{array}{c}\text { Real } \\
\text { exchange } \\
\text { ratec }\end{array}$ & $\begin{array}{l}\text { Unemploy- } \\
\text { ment rated }\end{array}$ & $\begin{array}{c}\text { Employment } \\
\text { growth }\end{array}$ \\
\hline \multirow{9}{*}{$\tilde{\sigma}$} & $1979-82$ & 15.3 & 1.5 & n.a. & 2.4 & 100 & 12.2 & - \\
\hline & 1983 & 12.1 & 7.4 & -4.2 & —e & 91 & 17.0 & - \\
\hline & 1984 & 11.2 & 4.0 & -4.1 & 0.9 & 96 & 19.7 & -1.8 \\
\hline & 1985 & 8.8 & 2.2 & -4.5 & 0.8 & 98 & 21.1 & -0.9 \\
\hline & 1986 & 8.8 & 2.5 & -3.0 & 1.5 & 97 & 20.8 & 2.2 \\
\hline & 1987 & 5.2 & 6.2 & -0.5 & 4.9 & 100 & 20.1 & 3.1 \\
\hline & 1988 & 4.8 & 4.6 & -1.0 & 1.4 & 104 & 19.1 & 2.7 \\
\hline & 1989 & 6.8 & 6.3 & -0.1 & 3.1 & 109 & 16.9 & 2.2 \\
\hline & 1990 & 6.7 & 7.5 & -0.9 & 3.5 & 116 & 15.9 & 1.2 \\
\hline
\end{tabular}

n.a. Not applicable.

- Not available.

a. Realized real Treasury bill rate.

b. Percentage of GDP.

c. Index, $1980-82=100$.

d. OECD measure of the standardized unemployment rate.

e. Change in data series.

Source: International Monetary Fund, International Financial Statistics (various issues); OECD (various issues); Morgan Guaranty (various issues). 
1989.) Unemployment was extremely high, real interest rates remained very high, and the ratio of debt to GDP was steadily climbing. By 1991 it was quite clear that Ireland had indeed started turning the corner: growth was strong, inflation continued to be low, and a consensus had formed around the new macroeconomic policies. By 1992 the EMs crisis put success in question.

\section{Spain}

In the 1970s Spain had to grapple with the economic implications of the advent of democracy, the introduction of modern labor market institutions, and the oil shocks. As a result, in 1977 inflation reached 25 percent (see figure 9). Social agreements combining politics and the labor market started with the Moncloa Agreements in 1977 (see especially Blanchard and Bentolila 1990, Coricelli 1990, and Jimeno and Toharia 1991). Since then disinflation in Spain has brought into play the full range of instruments, from incomes policy to tight fiscal management, tight money, trade opening, and a real appreciation (see table 15). Joining the EMS in 1989 represented what was hoped to be the final measure to lock in disinflation.

As in the case of Ireland, it is difficult to disentangle which of the policy instruments played the dominant role. It is clear from table 15 that unemployment was certainly a major factor, however imperfectly the unemployment rate measures slack in the labor market. With high growth of the labor force, nega-

Figure 9. The Rate of Inflation in Spain, 1973-92

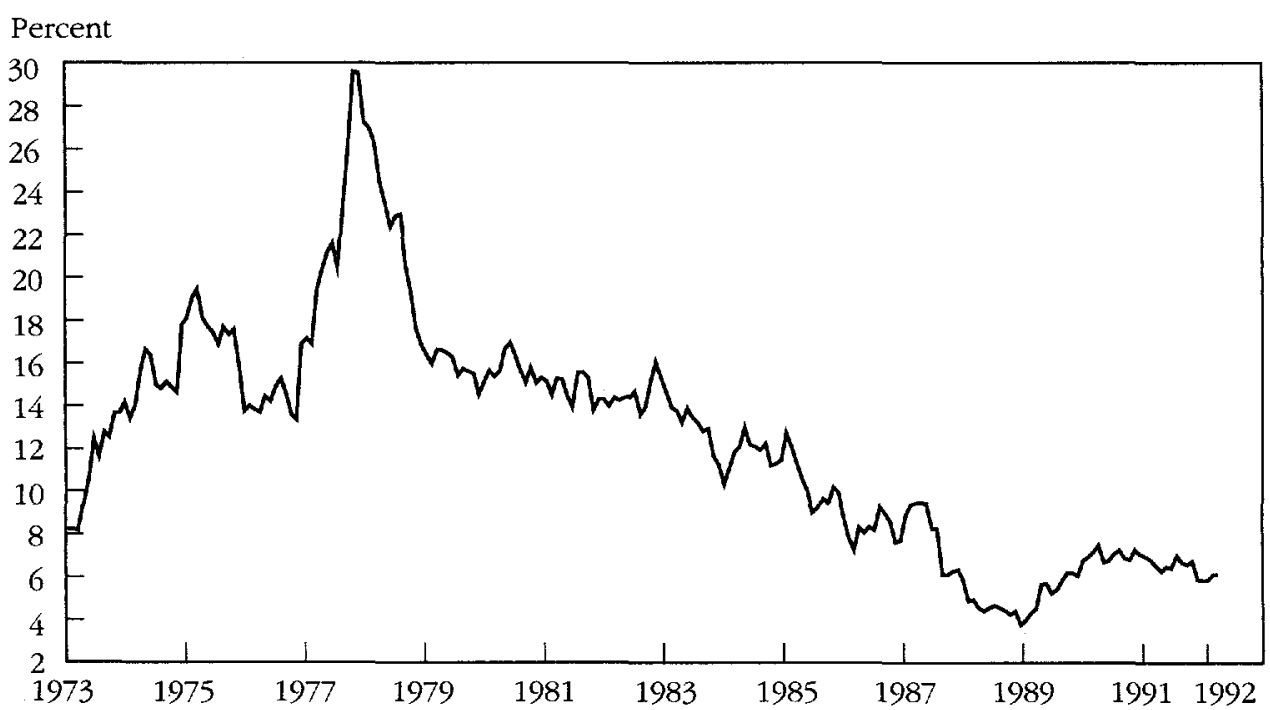

Note: The rate of inflation is measured by the change in the 12-month consumer price index. Data are monthly from January 1973 to February 1992.

Source: International Monetary Fund, International Financial Statistics (various issues). 
tive or moderate rates of employment growth directly add to unemployment. But special features of the labor market, notably significantly rising female labor force participation, make it difficult to compare the unemployment rate over time.

The rise in unemployment is not difficult to understand: monetary policy tightened very sharply with a shift, paralleling that in other countries, to realized real interest rates on Treasury bills from 1.5 percent in 1979-82 to more than 5 percent on average in the 1983-90 period. After 1985-86 a sharp tightening of fiscal policy reinforced the disinflationary stance of aggregate demand policies. Exchange rate policy also shifted to an unaccommodating stance in 1985 , when the sustained real appreciation started.

Observers of Spain's disinflation place importance on the neo-corporatist industrial relations structure (see Coricelli 1990 and Jimeno and Toharia 1991). The basic proposition is that in a centralized industrial relations setting that involves joint bargaining among labor, the government, and firms, better tradeoffs between inflation and unemployment can be realized than in a less structured setting, where essential coordination issues may go unresolved. In Spain's case, explicit wage agreements as part of the concertación social were particularly important in the period 1985-86. Wage agreements sharply reduced the rate of wage increases to below the level of inflation in the preceding year, thus making it possible to push disinflation ahead, as in equation 10 (see table 16). The cut in real wages, as a result of unemployment and wage agreements, thus served as the disinflation mechanism.

Wage agreements were supported by a disinflation strategy involving exchange rate management on the trade side. Figure 10 shows the real appreciation of the peseta since 1985. The progressive opening of trade required by Common Market membership created import competition that, along with the exchange rate commitment, increased domestic disinflationary pressure.

Spanish disinflation, like the Irish, involved a long, hard slog. The exchange rate commitment no doubt helped maintain the resolve of the Spanish government, and concertación made the need for coordinated reductions in price and

Table 16. Wage Contracts and Inflation in Spain, 1983-89 (percent)

\begin{tabular}{lcccc}
\hline & Increase & \multicolumn{2}{c}{ Rate of inflation } \\
\cline { 4 - 5 } Year & in wage & & Former \\
\cline { 3 - 4 } & contract & Current & year \\
\hline 1983 & 11.4 & 12.1 & 14.4 \\
1984 & 7.8 & 11.2 & 12.1 \\
1985 & 7.9 & 8.8 & 11.2 \\
1986 & 8.2 & 8.8 & 8.8 \\
1987 & 6.5 & 5.2 & 8.8 \\
1988 & 6.4 & 4.8 & 5.2 \\
1989 & 6.7 & 6.8 & 4.8 \\
\hline
\end{tabular}

Source: Jimeno and Toharia (1991). 
Figure 10. The Real Exchange Rate in Spain, 1970-92

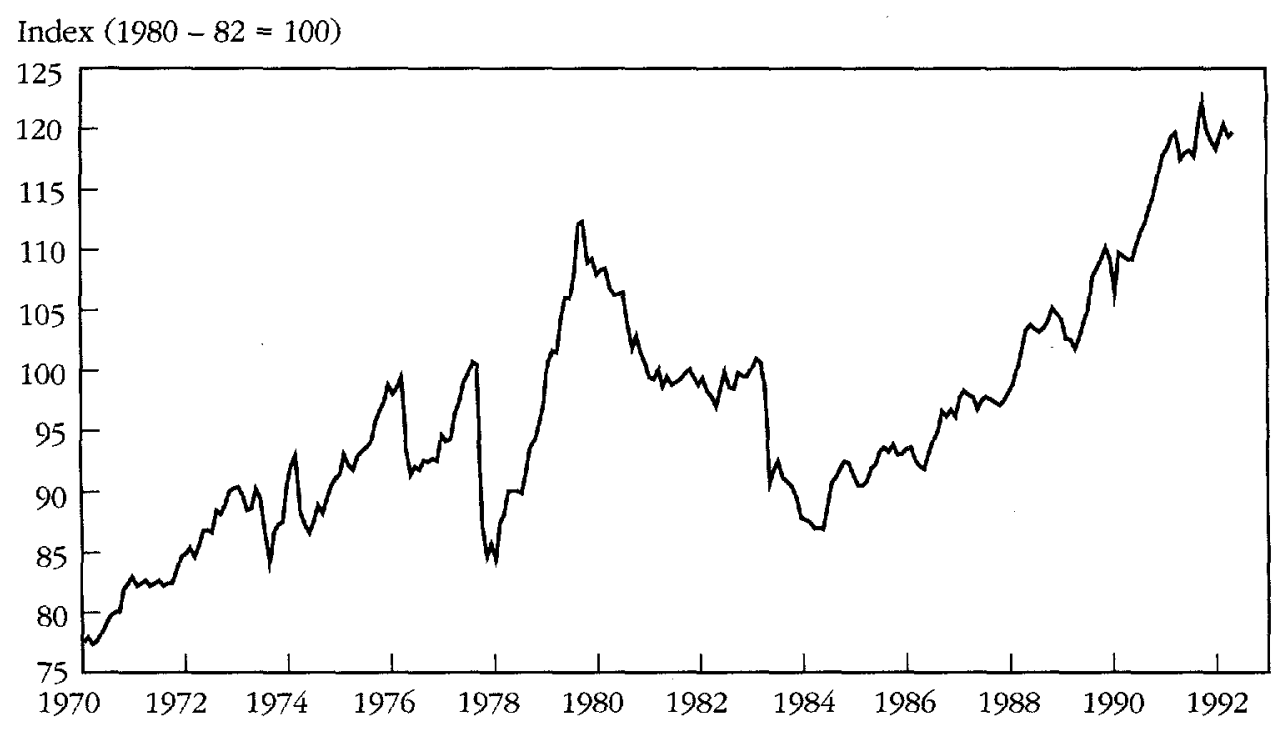

Note: Data are monthly from January 1970 to April 1992.

Source: International Monetary Fund International Financial Statistics (various issues).

wage inflation explicit, but these measures did not make possible a disinflation without tears.

\section{Conclusions}

Most of the countries whose experiences are studied here reached moderate or high inflation as a result of external shocks, particularly in commodity prices. Countries that remained in the moderate-inflation range after arriving there, notably Colombia, Chile, and, for a shorter time, Mexico, did so only by taking decisive action to prevent inflation from rising at certain specific points. Brazil, which was not willing to slow growth to stay in the moderate-inflation range, found itself as a result with high, sometimes extreme, inflation.

Three of the countries that successfully disinflated to low inflation-Ireland, Korea, and Spain-did so at a significant cost to output. Each of those countries used nonmarket measures-the equivalent of an incomes policy-to assist the disinflation. In Korea wage growth was reduced through restraints on public sector wages and by exercising moral suasion on the private sector. Even in Indonesia subsidization of rice constituted an unorthodox, incomes-type policy. There is little evidence in the data that the Indonesian disinflation imposed significant output costs.

Each of the disinflations was accompanied by a very strong fiscal contraction. Fiscal contractions were also undertaken in Chile and Mexico to reduce high inflation to the moderate range, and in Colombia to keep inflation moderate. 
Countries in the moderate-inflation range typically had exchange rates that were managed, such as crawling pegs or rates with intermittent depreciation. The European disinflators, Ireland and Spain, used an exchange rate commitment as part of their disinflationary strategy. Mexico likewise relied on an exchange rate anchor in bringing down high inflation. None of the evidence reviewed for this article, nor evidence in other studies, establishes firmly that the exchange rate commitment significantly reduced the costs of disinflation.

Indexation and disindexation appear to have played an important role in the Latin American inflations and disinflations. ${ }^{16}$ In Mexico, in the context of the Pacto, the departure from backward-looking pay increases was an essential part of the stabilization. Colombia in effect decided to live with inflation by permitting the introduction of indexation. Neither Korea nor Indonesia used explicit indexation widely, nor did Spain or Ireland. Whether disinflation is easier in the absence of indexation, or whether the absence of indexation indicates a government's commitment not to live with inflation, is difficult to say at this point.

Seigniorage revenue accounted for a significant share of government revenue in most of the moderate-inflation countries. Seigniorage was especially high at the start of most of the inflationary episodes. This affected the fiscal effort that had to be made to reduce inflation, but there is little evidence in the literature that seigniorage considerations played an important role in the thinking of any government. This absence may reflect a general lack of understanding of the inflationary process, or may rather mean that seigniorage is rarely an explicit reason for a government to pursue inflationary policies. We believe the latter interpretation.

In summary, there is unfortunately little encouragement in these case studies for the view that an exchange rate commitment, or incomes policy, allows a country to move at low cost from moderate to low inflation. ${ }^{17}$ Governments have successfully reduced moderate inflations to low inflations through a combination of tight fiscal policy, incomes policy, and generally some exchange rate commitment-and by taking advantage of favorable supply shocks to ratchet the inflation rate down.

\section{REFERENCES}

The word "processed" describes informally reproduced works that may not be commonly available through library systems.

Aghevli, Bijan, and Jorge Marquez-Ruarte. 1985. A Case of Successful Adjustment: Korea's Experience during 1980-84. IMF Occasional Paper 39. Washington, D.C.: International Monetary Fund.

16. In Italy (not reviewed here), disindexation of wages played a critical role.

17. We say "little" rather than "no" encouragement because Indonesia in fact stabilized at apparently low cost. The governmental structure, level of economic development, and relative unimportance of industry in Indonesia mean that the precedent is not especially relevant to more industrialized and developed economies. 
Andersen, Torben. 1989. "Credibility of Policy Announcements." European Economic Review 33(1): 13-20.

Arndt, H. W. 1974. "Survey of Recent Developments." Bulletin of Indonesian Economic Studies 10 (2, July): 1-34.

Bailey, Martin. 1956. "The Welfare Cost of Inflationary Finance." Journal of Political Economy 64 (2, April): 93-110.

Ball, Laurence. 1990. Credible Disinflation with Staggered Price Setting. NBER Working Paper 3555. Cambridge, Mass.: National Bureau of Economic Research.

- 1991. The Genesis of Inflation and the Costs of Disinflation. NBER Working Paper 3621. Cambridge, Mass.: National Bureau of Economic Research.

Barro, Robert. 1983. "Inflationary Finance under Discretion and Rules." Canadian Journal of Economics 16(1): 1-16.

Barro, Robert, and David Gordon. 1983. "A Positive Theory of Inflation in a Natural Rate Model." Journal of Political Economy 91 (4, August): 589-610.

Blackburn, Keith, and Michael Christensen. 1989. "Monetary Theory and Policy Credibility: Theories and Evidence." Journal of Economic Literature 27 (March): 1-45.

Blanchard, Olivier, and Samuel Bentolila. 1990. "Spanish Unemployment." Economic Policy 10 (April): 234-81.

Booth, Anne, and Peter McCawley. 1981. The Indonesian Economy During the Soeharto Era. New York: Oxford University Press.

Bruno, Michael. 1991. "High Inflation and the Nominal Anchors of an Open Economy." Princeton Essays in International Finance 183. International Finance Section, Princeton University. Processed.

Bruno, Michael, ed. 1988. Inflation and Stabilization. Cambridge, Mass.: MIT Press.

-1991. Lessons of Economic Stabilization and Its Aftermath: Inflation and Stabilization. Cambridge, Mass.: MIT Press.

Cagan, Phillip. 1956. "The Monetary Dynamics of Hyperinflation." In Milton Friedman, ed., Studies in the Quantity Theory of Money. Chicago: University of Chicago Press.

Calvo, Guillermo. 1983a. "Staggered Contracts and Exchange Rate Policy." In Jacob Frenkel, ed., Exchange Rates and International Macroeconomics. Chicago: University of Chicago Press.

—. 1983b. "Staggered Contracts in a Utility-Maximizing Framework." Journal of Monetary Economics 12 (3, September): 383-98.

Cardoso, Eliana, and Albert Fishlow. 1990. "The Macroeconomics of the Brazilian External Debt." In Jeffrey Sachs, ed., Developing Country Debt and Economic Performance, vol. 2. Chicago: University of Chicago Press.

CIEPLAN. Various issues. Estadísticas Económicas. Santiago, Chile.

Cole, D. C., and Y. C. Park. 1983. Financial Development in Korea, 1945-1978. Cambridge, Mass.: Harvard University Press.

Corbo, Vittorio. 1985. "International Prices, Wages, and Inflation in the Open Economy." Review of Economics and Statistics 67 (November): 564-73.

Corbo, Vittorio, and Sang-Woo Nam. 1992a. "Recent Experience in Controlling Inflation." In Vittorio Corbo and Sang-Mok Suh, eds., Structural Adjustment in a Newly Industrialized Country: The Korean Experience. Baltimore: Johns Hopkins University Press. 
1992b. "Recent Evolution of the Macroeconomy." In Vittorio Corbo and SangMok Suh, eds., Structural Adjustment in a Newly Industrialized Country: The Korean Experience. Baltimore: Johns Hopkins University Press.

Corbo, Vittorio, and Andres Solimano. 1991. "Chile's Experience with Stabilization Revisited.” PRE Working Paper 579. World Bank, Country Economics Department, Washington, D.C. Processed.

Coricelli, Fabrizio. 1990. "Industrial Relations and Macroeconomic Performance: An Application to Spain." wp/90/93. International Monetary Fund, Washington, D.C.

Dornbusch, Rudiger. 1980. Open Economy Macroeconomics. New York: Basic Books.

—. 1989. "Credibility, Debt, and Unemployment: Ireland's Failed Stabilization." Economic Policy (April): 174-209.

Dornbusch, Rudiger, Federico Sturzenegger, and Holger Wolf. 1990. "Extreme Inflation: Dynamics and Stabilization." Brookings Papers on Economic Activity 2: 2-84.

Driffill, John. 1989. “Macroeconomic Policy Games with Incomplete Information.” European Economic Review 32: 533-41.

Edwards, Alejandra, and Sebastian Edwards. 1987. Monetarism and Liberalization. Cambridge, Mass.: Ballinger.

Fellner, William. 1981. "Shock Therapy or Gradualism." In William Fellner, ed., Shock Therapy or Gradualism? A Comparative Approach to Anti-inflation Policies. New York: Group of Thirty.

Fischer, Stanley. 1977. "Long-Term Contracts, Rational Expectations, and the Optimal Money Supply Rule." Journal of Political Economy 85(1): 191-205.

—_. 1983. "Seigniorage and Fixed Exchange Rates: An Optimal Inflation Tax Analysis." In Pedro Aspe Armella, Rudiger Dornbusch, and Maurice Obstfeld, eds., Financial Policies and the World Capital Market: The Problem of Latin American Countries. Chicago: University of Chicago Press.

. 1986. "Contracts, Credibility, and Disinflation." In Indexing, Inflation, and Economic Policy. Cambridge, Mass.: MIT Press.

- 1988. "Real Balances, the Exchange Rate, and Indexation: Real Variables in Disinflation." Quarterly Journal of Economics 103(1): 27-50.

Fishlow, Albert. 1974. "Indexing Brazilian Style: Inflation without Tears." Brookings Papers on Economic Activity 1: 261-80.

Foxley, Alejandro. 1983. Latin American Experiments in Neo-Conservative Economics. Berkeley: University of California Press.

Friedman, Milton. 1971. “Government Revenue from Inflation.” Journal of Political Economy 79 (4, July-August): 846-56.

Fuhrer, J., and G. Moore. 1990. "Monetary Policy Rules and the Indicator Properties of Asset Prices." In Richard Porter, ed., Asset Prices and the Conduct of Monetary Policy. Washington, D.C.: Board of Governors of the Federal Reserve.

Gelb, Alan, and Bruce Glassburner. 1988. "Indonesia: Windfalls in a Poor Rural Economy." In Alan Gelb, ed., Oil Windfalls: Blessing or Curse? New York: Oxford University Press.

Gillis, Malcolm. 1984. "Episodes in Indonesian Economic Growth." In Arnold Harberger, ed., World Economic Growth. San Francisco: Institute of Contemporary Studies.

Glassburner, Bruce, ed. 1971. The Economy of Indonesia. Ithaca, N.Y.: Cornell University Press. 
Government of Korea. 1990. Major Statistics of the Korean Economy. Seoul: National Bureau of Statistics, Economic Planning Board.

Hommes, Rudolfo. 1990. "Colombia." In John Williamson, ed., Latin American Adjustment. Washington, D.C.: Institute for International Economics.

International Monetary Fund. Various issues. International Financial Statistics. Washington, D.C.

- Various issues. Government Financial Statistics. Washington, D.C.

Jimeno, J., and Luis Toharia. 1991. "Spanish Labor Markets: Institutions and Outcomes." Universidad de Alcala de Henares, Madrid. Processed.

Keynes, J. M. 1923. A Tract on Monetary Reform. Reprinted by the Royal Economic Society, London, 1971.

Kiguel, Miguel, and Nissan Liviatan. 1990. "Some Implications of Policy Games for High Inflation Economies.” PRE Working Paper 379. World Bank, Country Economics Department, Washington, D.C. Processed.

Kremers, J. J. M. 1990. "Gaining Policy Credibility for a Disinflation: Ireland's Experience in the EMs." IMF Staff Papers 37 (1, March): 116-45.

Lipsey, Richard, ed. 1990. Zero Inflation: The Goal of Price Stability. Toronto: C. D. Howe Institute.

McCawley, Peter. 1973. "Survey of Recent Developments." Bulletin of Indonesian Economic Studies 9 (3, November): 1-27.

Modigliani, Franco, and Tommaso Padoa-Schioppa. 1978. "The Management of an Open Economy with ' $100 \%$ Plus' Indexing." Princeton Studies in International Finance.

Morgan Guaranty. Various issues. World Financial Markets.

Nam, Sang-woo. 1984. "Korea's Stabilization Efforts since the Late 1970s." Working Paper 8405 (March). Korea Development Institute.

OECD (Organisation for Economic Co-operation and Development). Various issues. Economic Outlook.

Papanek, Gustav F., ed. 1980. The Indonesian Economy. New York: Praeger.

Persson, Torsten. 1988. "Credibility of Macroeconomic Policy: An Introduction and a Broad Survey." European Economic Review 32: 519-32.

Persson, Torsten, and Guido Tabellini. 1989. "Macroeconomic Policy, Credibility, and Politics." University of California at Los Angeles. Processed.

Phelps, Edmund S. 1973. "Inflation in a Theory of Public Finance." Swedish Journal of Economics 75(1): 67-82.

Ramos, Joseph. 1986. Neo-conservative Economics in the Southern Cone of Latin America, 1973-83. Baltimore: Johns Hopkins University Press.

Sargent, Thomas. 1982. "The Ends of Four Big Inflations." In Robert Hall, ed., Inflation. National Bureau of Economic Research and University of Chicago Press. 1986. Rational Expectations and Inflation. New York: Harper and Row.

Selody, Jack. 1990. "The Goal of Price Stability: A Review of the Issues." Technical Report 54. Ottawa: Bank of Canada.

Simonsen, Mario. 1974. A Nova Economia Brasileira. Rio de Janeiro: Jose Olympio.

- 1986. "Indexation: Current Theory and the Brazilian Experience." In Rudiger Dornbusch and Mario Simonsen, eds., Inflation, Debt, and Indexation. Cambridge, Mass.: MIT Press. 
Taylor, John B. 1980. "Aggregate Dynamics and Staggered Contracts." Journal of Political Economy 88 (1, February): 1-23.

- 1982. "The Role of Expectations in the Choice of Monetary Policy." In Federal Reserve Bank of Kansas City, Monetary Policy Issues in the 1980s. Kansas City.

—. 1983. "Union Wage Settlements during a Disinflation." American Economic Review 73 (5, December): 981-93.

Tobin, James. 1980. "Stabilization Policy Ten Years Afterwards." Brookings Papers on Economic Activity 1:18-71.

Urrutia, Miguel. 1989. "The Politics of Fiscal Policy in Colombia." In Miguel Urrutia, ed., The Political Economy of Fiscal Policy. Tokyo: United Nations University.

World Bank. 1984. "Colombia: Economic Development and Policy under Changing Conditions." Washington, D.C. Processed. 


\title{
External Shocks, Purchasing Power Parity, and the Equilibrium Real Exchange Rate
}

\author{
Shantayanan Devarajan, Jeffrey D. Lewis, and Sherman Robinson
}

Two approaches are commonly used to determine the equilibrium real exchange rate in a country after external shocks: purchasing power parity (PPP) calculations and the Salter-Swan, tradables-nontradables model. There are theoretical and empirical problems with both approaches, and tensions between them. In this article we resolve these theoretical and empirical difficulties by presenting a model which is a generalization of the Salter-Swan model and which incorporates imperfect substitutes for both imports and exports. Within the framework of this model, the definition of the real exchange rate is consistent both with that of the PPP approach and with that of the Salter-Swan model (suitably extended). Our model, however, is capable of capturing a richer set of phenomena, including terms of trade shocks and changes in foreign capital inflows. It also provides a practical way to estimate changes in the equilibrium real exchange rate, requiring little more information than is required to do PPP calculations. The results are consistent with those of multisector computable general equilibrium models, which generalize the trade specification of the small model.

Faced with sharp increases in real interest rates, cutbacks in foreign lending, and deteriorating terms of trade-all of which lower the sustainable level of a country's current account balance-developing countries since the mid-1970s have been forced to reduce their trade deficits or, in some cases, to run surpluses. They have adopted structural adjustment programs, often with the assistance of the International Monetary Fund or World Bank, aimed at facilitating the transition to lower current account deficits. A common ingredient in all these programs is a real depreciation of the exchange rate. A depreciated exchange rate, it is argued, will increase the competitiveness of exports, make imports more expensive, and shift resources from sectors producing nontradables to those producing tradables.

Shantayanan Devarajan is with the Country Economics Department at the World Bank and the John F. Kennedy School of Government at Harvard University; Jeffrey D. Lewis is with the Harvard Institute for International Development at Harvard University; and Sherman Robinson is with the Department of Agricultural and Resource Economics at the University of California at Berkeley. The authors are grateful to Ravi Kanbur, three referees, and two members of the editorial board of this journal for useful comments.

(C) 1993 The International Bank for Reconstruction and Development/THE WORLD BANK 
Implicit in the recommendation of a devaluation is the view that the real exchange rate is out of equilibrium. But by how much is it out of equilibrium? What is the equilibrium exchange rate? Policymakers need answers to these questions to determine how large the exchange rate adjustment must be and how large a shock the domestic price system must sustain. The most common approach is to calculate the purchasing power parity (PPP) equilibrium exchange rate (Dornbusch 1987; Edwards 1989; Cavallo and Cottani 1986). Following this approach, we define the real PPP exchange rate $\left(R^{r}\right)$ as the ratio of the nominal exchange rate $(R)$ multiplied by the ratio of an aggregate index of world prices $(\pi)$ divided by an index of domestic prices $(P)$ :

$$
R^{r}=R \frac{\pi}{P}
$$

The PPP approach is to find a prior benchmark year when the current account was in equilibrium at some sustainable level (perhaps, but not necessarily, zero). The real exchange rate for that year is assumed to be the desired equilibrium real rate for the postshock period. The equilibrium nominal rate is then calculated by computing the inflation differential between the country and its trading partners since the benchmark year. Because $\hat{R}^{r}=0$ by assumption, the required nominal rate of depreciation or appreciation is given by $\hat{R}=\hat{P}-\hat{\pi}$, where a hat over a variable indicates a rate of change. Note that $R$ is defined as the price in domestic currency of a unit of foreign exchange. An increase in $R$ denotes a depreciation of the exchange rate.

The PPP approach has been criticized on both theoretical and empirical grounds. An obvious problem is that the external environment and structure of the economy will have likely changed since the last time the current account was in equilibrium. Consequently, the real exchange rate for the benchmark year will not be an equilibrium value in the postshock period. Another strand of criticism has focused on the appropriate empirical definition of the real exchange rate. In neoclassical trade theory, the real exchange rate is defined as the relative price of tradable to nontradable goods. In the empirical application of the PPP approach, however, the usual practice is to measure domestic prices using an aggregate price index such as the gross domestic product (GDP) deflator and to measure world prices using a similar aggregate index for the trading partners. One problem with this empirical practice is that the measure of domestic prices includes not only nontradables but also tradables produced or bought by the country, and the measure of world prices includes not only tradables but also nontradables produced by the trading partners. As Edwards (1989) points out, the inclusion of both tradables and nontradables in the index of domestic prices is not a problem for reflecting the direction of change of the relative price of tradables to nontradables. If $P=P_{T}^{\alpha} P_{N}^{1-\alpha}$, then $\hat{R}=(1-\alpha)\left[\hat{P}_{T}-\hat{P}_{N}\right]$ (where $P_{T}$ is the price index for tradable goods and $P_{N}$ is the price index for nontradable goods). Thus the rate of change of the nominal exchange rate, $\hat{R}$, represents 
$(1-\alpha)$ times the change in the ratio of the price index of tradables to the price index of nontradables $\left(P_{T}\right.$ to $\left.P_{N}\right)$.

An alternative approach is not to use standard aggregate price indexes but, instead, to define separate indexes for tradable and nontradable goods produced or sold in the country. Here the difficulty is with the definition of nontradables. Based on the Salter-Swan model of a small open economy, the proper definition of a nontradable sector is one in which there are neither exports nor competing imports (Salter 1959; Swan 1960). In addition, a sector might be tradable even if there is no trade observed. Using this definition, even looking at very disaggregated data, there are only a few nontraded sectors. Any resulting price index for nontraded goods reflects only a tiny share of GDP.

Furthermore, the Salter-Swan model does not distinguish between exports and imports. At the sectoral level, exportables and import substitutes are quite different. In developing countries, for example, exportables are usually primary goods or light manufactures whereas imports consist largely of intermediates and capital goods for which there are limited domestic substitutes. Aggregating these two types of goods into a single tradables sector will distort the view of how such a country adjusts, say, to a change in its international terms of trade.

The approach we present in this article resolves these theoretical and empirical difficulties in defining the equilibrium real exchange rate (ERER). We extend the Salter-Swan model to incorporate imperfect substitutes for both exports and imports, an approach we feel is especially realistic for developing countries. Both the PPP and Salter-Swan approaches are special cases of this extended model, under restrictive assumptions, and the extended model provides a practical alternative to estimating changes in the equilibrium exchange rate that is both theoretically and empirically superior to the PPP approach.

In section I, we present the extension of the Salter-Swan model. In section II, we derive the equilibrium real exchange rate for the model and show how it responds to changes in foreign capital inflows and the international terms of trade. In section III we discuss alternative approaches and, applying the model to Cameroon and Indonesia, present some illustrative calculations comparing how the different approaches measure changes in the equilibrium exchange rate.

\section{A Single-Country, Two-Activity, Three-Commodity Model}

In a small economy in which all goods are traded, domestic relative commodity prices are completely determined by world prices (and the trade policy regime). In such a country, changes in the exchange rate have no effect on relative prices and hence on sectoral resource allocation. It is convenient and common in trade theory to work with analytic models that assume all goods are tradable. Disaggregated theoretical models in this tradition, however, are not well suited for the analysis of structural adjustment. In countries adjusting to external shocks, such as changes in foreign capital inflows or movements in world prices, 
the response of domestic relative prices to changes in the equilibrium exchange rate and trade policy are central to the analysis. In addition, empirical multisector models that start from the assumption that all goods are tradable tend to yield wildly unrealistic sectoral specialization in production and also greatly overstate the empirical response of domestic prices to external shocks.

As an alternative, consider a country that produces two goods-a nontraded domestic good, $D$, and an export, $E$. The country also consumes two goodsthe domestic good and an import, $M$. The corresponding prices are $P^{d}, P^{e}$, and $\mathrm{P}^{m}$. We assume that the country does not consume the export good. (This assumption is not restrictive; if, in fact, the citizens of the country do consume the export commodity, we classify the domestic consumption under $D$.) We will call this one-country, two-activity, three-commodity model the 1-2-3 model. The equations are set out in table 1.

The domestic and export goods are assumed to be imperfect substitutes. Therefore it is costly to change the allocation of goods between the domestic and export markets. The imperfect substitutability is captured by the economy's production possibility frontier, for convenience specified as a constant elasticity of transformation (CET) function (equation 1). Alternatively, the domestic and export goods can be viewed as being produced by two different sectors that compete for the same factor that is in fixed supply. If the production functions of the two sectors are Cobb-Douglas, then the resulting production possibility frontier has a constant elasticity of transformation. Devarajan, Lewis, and Robinson (1990) provide a more complete discussion of the properties of the model and its relationship to multisector models. Profit-maximization by producers, given the CET transformation frontier, yields the first-order conditions of equation 3 . The relative supplies of the domestic good and exports depend on their relative domestic prices, $P^{d}$ and $P^{e}$, and on the elasticity of transformation, $\Omega$.

The output of the domestic good is also assumed to be an imperfect substitute for imports in consumption, with a constant elasticity of substitution (CES) function (equation 2). ${ }^{1}$ The first-order condition for utility-maximizing consumers is given by equation 4 , which defines the import demand function. The relative demands for imports and the domestic good depend on their relative domestic prices, $P^{m}$ and $P^{d}$, and on the elasticity of substitution, $\sigma$. In this model the domestic good sector is both the nontradable (as in the Salter-Swan model) and the import substitute.

Equations 5 and 6 define the domestic prices of the two traded goods. We take $\pi^{e}$ and $\pi^{m}$, the world prices of exports and imports, to be fixed exogenously (the small-country assumption). The variable $R$ is the nominal exchange rate and will serve as the numeraire price (equation 8 ). Finally, we impose a balance-of-

1. The constant elasticity assumptions are by no means innocuous. Tests of the homotheticity of preferences, for example, have proven quite inconclusive. Hinojosa and Robinson (1991) extend the model to incorporate more general utility functions. For our purposes, however, these functions can be thought of as local approximations. 
Table 1. The 1-2-3 Model

\begin{tabular}{ll}
\hline Item or symbol & Equation or definition \\
\hline Production possibility frontier & $(1) \bar{X}=G(E, D ; \Omega)$ \\
Import aggregation function & $(2) \quad Q=F(M, D ; \sigma)$ \\
Export supply function & $(3) \quad \frac{E}{D}=g(P e, P d ; \Omega)$ \\
& $(4) \quad \bar{D}=f(P m, P d ; \sigma)$ \\
Import demand function & $(5) P^{m}=R \cdot \pi^{m}$ \\
Domestic price of imports & $(6) P^{e}=R \cdot \pi^{e}$ \\
Domestic price of exports & $(7) \pi^{m} \cdot M-\pi^{e} \cdot E=\bar{B}$ \\
Balance of trade & $(8) R \equiv 1$ \\
Numeraire & \\
Endogenous variables & Exports \\
$E$ & Imports \\
$M$ & Domestic good sold on domestic market \\
$D$ & Composite good (absorption) \\
$Q$ & Domestic price of exports \\
$P^{e}$ & Domestic price of imports \\
$P^{m}$ & Domestic price of domestic good \\
$P^{d}$ & Nominal exchange rate \\
$R$ & \\
$E x o g e n o u s$ variables & Aggregate output (or GDP) \\
$\bar{X}$ & World price of exports \\
$\pi^{e}$ & World price of imports \\
$\pi^{m}$ & Balance of trade \\
$\bar{B}$ & Elasticity of transformation in supply \\
$\Omega$ & Elasticity of substitution in demand \\
$\sigma$ &
\end{tabular}

trade constraint, equation 7 . This states that the trade balance (written as imports minus exports) is fixed exogenously at $\bar{B}$.

The system of equations 1 to 8 has eight unknowns: exports, domestic goods sold on the domestic market, imports, the domestic price of exports, the domestic price of the domestic good, the domestic price of imports, the nominal exchange rate, and the composite good (absorption). Note that any solution to the system depends only on relative prices. The system is a general equilibrium model with two production activities (exports and domestic goods) and three distinct goods (export, domestic, and import). We have implicitly introduced the equilibrium condition on the domestic market by using the same domestic good variable for both supply (in equations 1 and 3) and demand (equations 2 and 4). Furthermore, Walras's law is satisfied because, by premultiplying equation 7 by the nominal exchange rate and adding $P^{d} \cdot D$ on both sides, we obtain $P e \cdot E+$ $P^{d} \cdot D+R \cdot \bar{B}=P^{m} \cdot M+P^{d} \cdot D$, which states that income equals expenditure.

The 1-2-3 model contains no monetary elements: it only determines relative prices; the balance of trade is exogenous; and there are neither assets nor any financial variables. It is a "real" model that identifies an equilibrium relationship (between the real exchange rate and the trade balance) which should be an essential feature of any macroeconomic model concerned with structural adjust- 
ment. As described here, the 1-2-3 model contains no explicit policy instruments, but it can be-and has been-extended to include, for example, taxes and government expenditure (Devarajan and de Melo 1987; Devarajan, Lewis, and Robinson 1990).

\section{The Analytics of the Equilibrium Real Exchange Rate}

In the 1-2-3 model, assuming that equations 1 and 2 are CET and CEs functions allows us to rewrite the first-order conditions:

$$
\begin{aligned}
& \frac{M}{D}=k_{1}\left[\frac{P^{d}}{P^{m}}\right]^{\sigma} \\
& \frac{E}{D}=k_{2}\left[\frac{P^{e}}{P^{d}}\right]^{\Omega} .
\end{aligned}
$$

The various share parameters in the CES and CET functions have been gathered into the constant terms in equations 9 and 10. Alternatively, equations 9 and 10 can be seen as local approximations of arbitrary import-demand and exportsupply functions. If a nonhomothetic function is used, equations 9 and 10 will include an income effect.

In addition, we rewrite the balance of trade equation, specifying the balance of trade, $B$, as a share of export earnings $(\lambda-1)$ :

$$
\pi^{m} \cdot M=\lambda \cdot \pi^{e} \cdot E
$$

where

$$
B=(\lambda-1) \cdot \pi^{e} \cdot E=\pi^{m} \cdot M-\pi^{e} \cdot E .
$$

The parameter $\lambda$ can be interpreted as the country's sustainable balance of trade, or the proportion by which imports can exceed exports. Thus, a trade balance of zero corresponds to a $\lambda$ of 1 . This treatment is convenient when considering proportional changes, because the rate of growth of $\lambda$ is well defined, even when the balance of trade is initially zero. Note that when the balance of trade is initially different from zero, a fixed $\lambda$ does not correspond to a fixed balance of trade, because the balance of trade will vary with the value of exports.

$\log$ differentiation $(\mathrm{d} \log (X)=\hat{X}=d X / X)$ of equations 9 to 11 yields:

$$
\begin{gathered}
\hat{M}-\hat{D}=\sigma\left(\hat{P}^{d}-\hat{P}^{m}\right) \\
\hat{E}-\hat{D}=\Omega\left(\hat{P}^{e}-\hat{P}^{d}\right) \\
\hat{\pi}^{m}+\hat{M}=\hat{\lambda}+\hat{\pi}^{e}+\hat{E}
\end{gathered}
$$

Note that because $R$ is the numeraire, $\hat{R} \equiv 0$, so that $\hat{P}^{m}=\hat{\pi}^{m}$ and $\hat{P}^{e}=\hat{\pi}^{e}$.

Unlike simple models with a single tradable good, this model recognizes that the incentive to consume imports versus domestic goods is different from the 
incentive to produce for exports versus the domestic market. In effect, there are two real exchange rates in this model. The first is the import or demand real exchange rate, $R^{m}=R \cdot \pi^{m} / P^{d}=P^{m} / P^{d}$, which captures the incentives to consume tradables versus nontradables. The second is the export or supply real exchange rate, $R^{e}=R \cdot \pi^{e} / P^{d}=P^{e} / P^{d}$, which captures the relative profitability of producing for the domestic or export markets. The 1-2-3 model thus extends the Salter-Swan model in distinguishing between two kinds of tradables, with separate demand and supply real exchange rates. With the nominal exchange rate as the numeraire price, the numerator in both measures is fixed by world prices. The only endogenous price in the model is the domestic price of the domestic good, which is common to both. Shocks that do not involve changes in world prices (such as a change in foreign capital inflow) will only affect the domestic price of the domestic good and hence will affect both real exchange rate measures identically.

Because the price of the domestic good is the important relative price determining the real exchange rate, we want to solve for it in terms of the rates of change in the world price of imports and the world price of exports $\left(\hat{\pi}^{m}\right.$ and $\left.\hat{\pi}^{e}\right)$, and changes in the sustainable trade balance $(\hat{\lambda})$. Subtracting equation 14 from equation 13 , substituting for $\hat{M}-\hat{E}$ in equation 15 , and manipulating yields

$$
\hat{P}^{d}=\frac{1}{\sigma+\Omega}\left[(\sigma-1) \cdot \hat{\pi}^{m}+(1+\Omega) \cdot \hat{\pi}^{e}+\hat{\lambda}\right] .
$$

Equation 16 is the core result. It gives the equilibrium change in the price of the domestic good for a given change in world prices or in foreign capital inflows, under the assumption that $\hat{R}=0$. Note that we are assuming that the changes in terms of trade are permanent and that the shift in $\lambda$ will persist. ${ }^{2}$ To facilitate comparison with the PPP approach, equation 16 can be rewritten with the rate of change in the nominal exchange rate included explicitly through a calculation of the price level deflated (PLD) exchange rate. The price level deflated exchange rate is defined in Krueger (1978) and Bhagwati (1978); here we specify a particular choice of price index for deflating the nominal exchange rate. Rearranging the terms from equation 16, the equilibrium PLD exchange rate is defined as:

$$
\begin{gathered}
\hat{R}-\hat{P} d=-\frac{\left(\sigma \cdot \hat{\pi}^{m}+\Omega \cdot \hat{\pi}^{e}\right)}{\sigma+\Omega}+\frac{\left(\hat{\pi}^{m}-\hat{\pi}^{e}\right)}{\sigma+\Omega}-\frac{\hat{\lambda}}{\sigma+\Omega} . \\
\text { PLD exchange rate } \quad \text { World inflation } \quad \text { Terms of trade } \begin{array}{r}
\text { Balance } \\
\text { of trade }
\end{array}
\end{gathered}
$$

The first term on the right of equation 17 adjusts the equilibrium PLD exchange rate for world inflation, the second term accounts for any change in the interna-

2. If nonhomothetic import-demand or export-supply functions are used, equation 16 will include an additional income-related term reflecting the difference in expenditure elasticities of import demand and export supply. 
tional terms of trade, and the third term accounts for any change in the sustainable balance of trade, where the sustainable level of foreign capital inflow is defined as a share of exports rather than as a fixed value.

Equation 17 can be rearranged to define a real PPP exchange rate variable, $R^{r}$, whose rate of change, $\hat{R}^{r}$, equals the change in the nominal exchange rate minus the inflation differential between the home country and its trading partners. The change in the equilibrium real exchange rate is given by

$$
\begin{gathered}
\hat{R}^{r}=\hat{R}-\left[\hat{P}^{d}-\frac{\left(\sigma \cdot \hat{\pi}^{m}+\Omega \cdot \hat{\pi}^{e}\right)}{\sigma+\Omega}\right]=\frac{\left(\hat{\pi}^{m}-\hat{\pi}^{e}\right)}{\sigma+\Omega}-\frac{\hat{\lambda}}{\sigma+\Omega} . \\
\text { Inflation differential }
\end{gathered}
$$

The usual PPP approach seeks to correct for the effect of differential inflation. In practice, the PPP approach ignores the terms of trade effect and handles the balance of trade effect by starting from a base in which the balance of trade is assumed to be in equilibrium (hence $\hat{\lambda}=0$ ). Equation 18 indicates that in the 1-2-3 model the equilibrium real PPP exchange rate will change only when there are changes in the international terms of trade or in the balance of trade. There is a conceptual similarity between equation 18 and the standard PPP approach, because the term in brackets in equation 18 measures the differential between domestic and world-price inflation rates, measured by a weighted average of the growth rates of the world prices of imports and exports. The weights in equation 18, however, are substitution and transformation elasticities, not trade shares, which are commonly used in defining world price indexes in the PPP approach.

In equation 16 , if $\hat{\pi}^{m}=\hat{\pi}^{e}=\hat{\pi}$ and $\hat{\lambda}=0$, then $\hat{P}^{d}=\hat{\pi}^{m}=\hat{\pi}^{e}$. Alternatively, in equation $18, \hat{R}^{r}=0$ and $\hat{R}=\hat{P}^{d}-\hat{\pi}$. The equilibrium real exchange rate does not change and the equilibrium nominal exchange rate is adjusted for differential domestic and (uniform) foreign inflation rates. In this case, the usual PPP approach also works, provided that the domestic price index is $P^{d}$ and the index of world prices contains only exportables and importables. With no terms of trade effect, the fact that the appropriate weights for defining the real exchange rate differ from the standard PPP approach does not matter. Put another way, at best, the standard PPP approach to computing changes in the equilibrium exchange rate is valid if, and only if there is no change in the international terms of trade and in the equilibrium, or sustainable, level of foreign capital inflow.

As either the elasticity of substitution in demand or the elasticity of transformation in supply ( $\sigma$ or $\Omega$ ) approaches infinity, the model collapses to the standard small-country model, in which all goods are tradable. In the limit, $\hat{P}^{d}=\hat{P}^{m}$ as $\sigma$ approaches infinity, and $\hat{P}^{d}=\hat{P}^{e}$ as $\Omega$ approaches infinity. In both cases the real exchange rate is independent of the balance of trade because the domestic price of the perfect substitute (either for exports or imports) is determined by the exogenous world price. In such models, the exchange rate has no role in determining relative prices. 
Consider now the impact of a change only in foreign capital inflow $(\hat{\lambda} \neq 0$, $\hat{\pi}^{m}=\hat{\pi}^{e}=0$ ) with elasticities less than infinity. An increase in the balance of trade deficit $(\hat{\lambda}>0)$ always generates a real appreciation $\left(\hat{P}^{d}>0\right.$ or, in equation $18, \hat{R}^{r}<0$ ). The model faithfully generates a "Dutch disease" scenario, whereby the real exchange rate appreciates when the economy acquires a windfall increase in foreign exchange earnings.

Next, consider an increase in the world price of imports, which corresponds to a worsening in the international terms of trade facing the country $\left(\hat{\pi}^{m}>0, \hat{\pi}^{e}\right.$ $=0$, and $\hat{\lambda}=0$ ). In this case, whether or not the price of the domestic good rises or falls depends on the value of the elasticity of substitution between imports and domestic goods. If the elasticity is less than one, a typical case for developing countries, there is a fall in the equilibrium price of nontradables. As $P^{e} / P^{d}$ rises, the country will shift resources into exports and away from nontradables in order to generate foreign exchange earnings to pay for the more expensive, crucial imports. Conversely, if the elasticity is greater than one, then an increase in import prices generates an increase in the price of nontradables. In this case, perhaps more typical of developed countries, an increase in the price of imports leads to a diversion of resources away from exportables into the production of domestic substitutes for the imported goods. The volume of trade also falls. The effects of balance-of-trade and terms of trade shocks on the equilibrium real exchange rate in the 1-2-3 model have also been analyzed by de Melo and Robinson (1989). The authors derive an explicit expression for the country's offer curve, solving for quantity as well as price effects.

In practice, it is common to define a single real exchange rate by using either some consumer price index or the GDP deflator rather than an index of the price of domestically produced goods sold on the domestic market, as called for in equation 16. These alternative indexes, however, include tradables. In the 1-2-3 model, the consumer price index corresponds to the price of the composite good purchased by consumers, and the GDP deflator corresponds to the price of domestic output. An index of composite good prices includes imports but excludes exports, and a domestic output index includes exports but excludes imports. However, it is straightforward to construct an appropriate index for domestically produced goods that are consumed domestically, based on national accounts data. The index can be constructed by removing export prices from the GDP deflator, using the expenditure identity

$$
\begin{aligned}
P^{x} \cdot X & =P^{d} \cdot D+P^{e} \cdot E \\
P^{d} & =\frac{P^{x}-S^{e} \cdot P^{e}}{1-S^{e}}
\end{aligned}
$$

where $S^{e}$ is the export share in real GDP.

The 1-2-3 model can also be linked with other approaches to calculating the real exchange rate. For example, the elasticities approach (see Krueger, Schiff, and Valdés 1988; Mundlak, Cavallo, and Domenech 1990; Dixit and Norman 
1980) extends earlier work applying the elasticities approach to the balance of payments to argue that the real exchange rate should be related to the elasticities of demand for and supply of foreign exchange.

Krueger, Schiff, and Valdés (1988) present a formula that is similar to equation 16 , but based on very different underlying theory. In the 1-2-3 model, the elasticities are parameters in the underlying structural import-demand and export-supply functions. The elasticities approach relies on a reduced-form equation without specification of the underlying structural model, which can lead to varying views of the appropriate structural model. For example, Krueger, Schiff, and Valdés (1988) assume that the entire nonagricultural sector consists of nontradable goods and services. Such an assumption, although convenient in their analysis, is at odds with the stylized facts characterizing most developing countries and plays no part in the structural underpinnings of the 1-2-3 model.

Mundlak, Cavallo, and Domenech (1990) employ a three-good model to look at the effects of macroeconomic policies on sectoral prices. The 1-2-3 model provides the general equilibrium model underlying their reduced-form specification. As in the 1-2-3 model, they specify different real exchange rates for supply and demand. They also obtain results that are similar to those obtained from the 1-2-3 model: the responses to a terms of trade shock are different on the real exchange rates for supply and demand. Indeed, the response parameter (called $\omega$ in their article), which gives the response of the real exchange rate to a change in the price of imports, is equal to $(\sigma-1) /(\sigma+\Omega)$ in the 1-2-3 model. Although Mundlak, Cavallo, and Domenech $(1990,57)$ note the possibility that the exchange rate will appreciate when there is a "low value of $\omega$," the 1-2-3 model decomposition using equation 16 enables us to describe the precise conditions under which tariff liberalization will result in an appreciation of the real exchange rate-namely, that $\sigma<1$. Moreover, they specify all three goods as domestically produced, and although they acknowledge that in Argentina "almost no domestically produced agricultural products are also imported", their framework makes it difficult for them to estimate the price of the home good; they argue that “. . . by the very fact that the home sector is not well defined, there are no direct observations on [its price]" (Mundlak, Cavallo, and Domenech 1990,64$)$. As the 1-2-3 model demonstrates, not only is the home sector well defined, but, in addition, its aggregate price is obtainable from national accounts data.

The 1-2-3 model also resembles the "fundamentals" approach to calculating the ERER (Williamson 1983). The fundamentals approach incorporates changes in external circumstances and domestic policy in determining the ERER, and is based on a reduced-form model. It also seeks to capture intertemporal elements that our static model ignores.

\section{EMPIRICAL EXAMPLES}

We illustrate our method of calculating the equilibrium real exchange rate (ERER) by applying the 1-2-3 model to Cameroon and Indonesia. Both countries 
are oil producers and suffered a major terms of trade shock in 1986 when the world price of oil plummeted. We compute the ERER in light of this shock and compare it with what would have been obtained using the standard PPP approach. Of course, neither method represents the true ERER, because the 1-2-3 model is highly aggregated and the price shock hit only a few sectors in each country. To capture these sectoral effects, we also calculate the ERER using a multisector computable general equilibrium (CGE) model of each country. The CGE model has the virtue of providing a more disaggregated picture of the economy, at the cost of added data requirements and complexity. We then compare the calculations based on the 1-2-3 model with those from the CGE model. The comparison provides some indication of the extent of error introduced by using a highly aggregated model.

Trade-focused, multisector CGE models, which generalize the trade specification of the 1-2-3 model, have been used to analyze structural adjustment in developing countries. A few studies used CGE models to explore the impact on the equilibrium exchange rate of various exogenous world-price shocks, changes in capital inflows, and domestic policy changes. The models serve as empirical laboratories for computing the decomposition presented in equation 18 . The results from multisector CGE models of Turkey (Dervis and Robinson 1982; Lewis and Urata 1984), Yugoslavia (Robinson and Tyson 1985), and Hungary (Kis, Robinson, and Tyson 1990) indicate that standard PPP calculations of the change in the equilibrium exchange rate can be badly off the mark, greatly underestimating the required devaluation. While supporting the arguments made in this article, these studies represent major research efforts and do not offer a simple alternative to the PPP approach. The question addressed below is, instead, whether calculations of changes in the equilibrium exchange rate based on the 1-2-3 model, which require little more information than that required to do PPP calculations, provide a feasible alternative that significantly improves on the PPP approach while at the same time remaining compatible with more disaggregated CGE models.

\section{Cameroon}

From 1982 to 1986, Cameroon's international terms of trade deteriorated significantly: its average export price fell by 28 percent, while the average import price rose by 12 percent. (Unless otherwise indicated, all data in this subsection are from World Bank 1989.) Most observers agreed that the country's real exchange rate in 1986 was out of equilibrium. But by how much?

Consider, first, what the application of the PPP approach would have yielded. In 1982 Cameroon's resource balance (the balance of trade in goods and nonfactor services) was zero. Thus 1982 would be an appropriate choice for the benchmark year. Between 1982 and 1986 the domestic price level in Cameroon (represented by the GDP deflator) rose by 31 percent. The price level in France (represented by the French consumer price index [CPI]) also rose by 31 percent during this period, and the exchange rate between the two countries was fixed (International Monetary Fund 1989). Honohan (1990) shows that inflation in 
the CFA countries as a whole was not significantly different from French inflation during 1965-88. In terms of domestic versus foreign inflation, Cameroon's real PPP exchange rate was evidently in equilibrium in 1986, despite the sizable deterioration in the terms of trade.

Even with no change in the balance of trade, the PPP calculation can be very misleading when there are changes in the international terms of trade. With the 1-2-3 model, we can take the relative price shock into account when estimating the change in the ERER. In doing so for Cameroon, we assume that the only shock facing the country was the change in international prices. Table 2 shows the change in the domestic price level during 1982-86 for different values of the export transformation and import substitution elasticities, given the actual changes in average export and import prices $(-28$ and +12 percent, respectively). The calculations use equation 16 .

The estimation of the export transformation and import substitution elasticities is clearly difficult in countries with limited data. Furthermore, as table 2 shows, numerical results from the 1-2-3 model are quite sensitive to these values, with the equilibrium changes in the domestic price level ranging from -28 to -88 percent, depending on the elasticities. One approach to estimating elasticities is to use values that represent the weighted average of sector-specific elasticities. Using sectoral values for the export transformation and import substitution elasticity for Cameroon presented in table 3 (taken from an 11-sector model of Cameroon) yields an average export elasticity of 0.5 and an import elasticity of 0.6 .

Using these average elasticities, the decline in the domestic price level required to achieve equilibrium is 46.2 percent. Using the decomposition in equation 18 , the equilibrium real devaluation is 36.4 percent, which is a far cry from the 0 percent prescribed by the usual PPP approach. Assuming that $\hat{R}$ is equal to zero, 36.4 percentage points of the 46.2 percent required fall in domestic prices is attributable to the deterioration in the terms of trade (changes in relative international prices). The required adjustment for differential inflation based on

Table 2. Changes in the Equilibrium Domestic Price Level in Cameroon, 1982-86 (percent)

\begin{tabular}{llccc}
\hline & \multicolumn{4}{c}{ Import substitution elasticity $(\sigma)$} \\
\cline { 2 - 5 } export transformation & 0.25 & 0.50 & 0.75 & 1.00 \\
\hline 0.25 & -88.0 & -54.7 & -38.0 & -28.0 \\
0.50 & -68.0 & -48.0 & -36.0 & -28.0 \\
0.60 & -63.3 & -46.2 & -35.4 & -28.0 \\
0.75 & -58.0 & -44.0 & -34.7 & -28.0 \\
1.00 & -52.0 & -41.3 & -33.7 & -28.0 \\
\hline
\end{tabular}

Note: Values are the percentage change in the domestic prices caused by a 12 percent change in import prices and a -28 percent change in export prices. The nominal exchange rate and the balance of trade are assumed to be unchanged. 
Table 3. Sectoral Shocks and Initial Trade Data, CGE Model for Cameroon

\begin{tabular}{|c|c|c|c|c|c|}
\hline \multirow[b]{2}{*}{ Sector } & \multicolumn{2}{|c|}{$\begin{array}{l}\text { Percentage change in } \\
\text { world price, 1982-86 }\end{array}$} & \multicolumn{2}{|c|}{$\begin{array}{c}\text { Base-year level } \\
\text { (billions of } 1985 \\
\text { CFA francs) }\end{array}$} & \multirow[b]{2}{*}{ Elasticity } \\
\hline & Imports & Exports & Imports & Exports & \\
\hline Capital goods & 20 & - & 448.9 & 20.6 & 0.40 \\
\hline Cash crops & - & -40 & 11.8 & 232.5 & 0.90 \\
\hline Cement & - & - & 65.8 & 35.9 & 0.75 \\
\hline Construction & - & - & 0.0 & 0.0 & 0.00 \\
\hline Consumer goods & 25 & - & 37.2 & 12.4 & 1.25 \\
\hline Food crops & - & - & 11.1 & 5.5 & 1.50 \\
\hline Food processing & - & - & 22.9 & 15.8 & 1.25 \\
\hline Forestry & - & - & 0.0 & 24.9 & 0.40 \\
\hline Intermediate goods & 20 & -50 & 208.6 & 379.6 & 0.50 \\
\hline Private services & - & - & 245.6 & 222.2 & 0.40 \\
\hline Public services & - & - & 0.0 & 0.0 & 0.00 \\
\hline
\end{tabular}

- No change.

Note: Import substitution and export transformation elasticities are the same in each sector.

world export and import prices (rather than on measures of general inflation for the trading partners) is 9.8 percentage points. Even using an appropriate PPP measure, the inflation differential accounts for only a small part $(21$ percent $=$ 9.8/46.2) of the equilibrium change in the domestic price level.

Given that the terms of trade shock affects only a few sectors, is there significant aggregation bias in using such an aggregated model? How different would the results be if we used a more disaggregated multisector model? We explore this issue by simulating the terms of trade shock with an 11-sector CGE model of Cameroon. (The CGE model of Cameroon is described in detail in Benjamin, Devarajan, and Weiner 1989.) Table 3 describes the sector-specific world-price shocks that Cameroon faced. In the aggregate, they closely approximate the terms of trade shock we assumed for the 1-2-3 model. The table also provides trade data and the sectoral elasticities of import substitution and export transformation.

A simulation of the CGE model with the shocks described in table 3 results in a decrease in the equilibrium domestic price level in Cameroon of 44.5 percent. The 1-2-3 model yielded a decrease of 46.2 percent. Of course, the disaggregated model provides a great deal more information, especially regarding the structural adjustment process at the sectoral level. However, the 1-2-3 model does an excellent job determining the equilibrium exchange rate.

\section{Indonesia}

The combination of plummeting oil prices and international currency realignment that began in late 1985 signaled an abrupt and painful end to the boom years in Indonesia. Not only did the price of oil drop from more than $\$ 30$ a barrel to $\$ 10$ a barrel within a few months, but also the weakening of the dollar 
against other currencies drastically raised the dollar servicing cost of Indonesia's debt (60 percent of which is in nondollar currencies, including 40 percent denominated in yen).

Faced with a terms of trade shock of this magnitude, the exchange rate came under pressure. In late 1986, policymakers responded with a 45 percent devaluation against the dollar. In an effort to forestall the rate creep that had followed earlier adjustments, they concurrently adopted a more flexible policy that allowed for frequent (even daily) adjustments in the nominal exchange rate in order to preserve the "real" benefits of the devaluation and maintain adequate incentives for exports.

With the PPP approach, the appropriate exchange rate adjustment depends only on the size of the inflation differential between Indonesia and the rest of the world. The first and most difficult task is to choose an appropriate benchmark for the PPP calculation. In no year since 1974 did Indonesia's current account come close to being balanced (that is, equal to zero). During the period, it vacillated between a $\$ 2.2$ billion surplus $(1979 / 80)$ and a $\$ 7.0$ billion deficit $(1982 / 83) .{ }^{3}$ An alternative way to choose a benchmark is to define a sustainable deficit as that of a "normal" year and base the Ppp from that point. From this perspective, the best choice would seem to be $1984 / 85$, when the deficit was around $-\$ 2.0$ billion. In the two years between $1985 / 86$ and $1987 / 88$, the Indonesian CPI changed by 18.6 percent, while the U.S. CPI changed by 7.0 percent. This would suggest a PPP nominal depreciation of 11.6 percent. Alternatively, the domestic price level will have to decline by 11.6 percent to restore the real exchange rate to its equilibrium value. But focusing only on dollar inflation seems incorrect because Indonesia's major export market (and creditor) is Japan. To make a rough correction, we average U.S. and Japanese inflation over the period, which lowers "world" inflation to 4 percent and consequently raises the PPP depreciation to 14.6 percent.

Table 4. Changes in the Equilibrium Domestic Price Level in Indonesia, 1985-87

(percent)

\begin{tabular}{lcccccc} 
& \multicolumn{6}{c}{ Import substitution elasticity $(\sigma)$} \\
\cline { 2 - 6 } $\begin{array}{l}\text { Export transformation } \\
\text { elasticity }(\Omega)\end{array}$ & 0.25 & 0.50 & 0.59 & 0.75 & 1.00 \\
\hline 0.25 & -64.8 & -37.1 & -31.0 & -23.2 & -14.9 \\
0.50 & -47.5 & -31.0 & -26.8 & -21.1 & -14.5 \\
0.57 & -44.4 & -29.7 & -25.9 & -20.6 & -14.4 \\
0.75 & -38.8 & -27.3 & -24.2 & -19.7 & -14.3 \\
1.00 & -33.6 & -24.9 & -22.4 & -18.7 & -14.1 \\
\hline
\end{tabular}

Note: Values are the percentage change in the domestic price caused by an 18 percent increase in import prices, a 13 percent decrease in export prices, and a 2.6 percent decline in the sustainable balance of trade. The nominal exchange rate is assumed to be unchanged.

3. All data are presented for Indonesian fiscal years, which run from April 1 to March 31 . Thus, $1979 / 80$ refers to April 1, 1979, to March 31, 1980, and is also called "fiscal year 1979." 
Table 5. Sectoral Shocks and Initial Trade Data, CGE Model for Indonesia

\begin{tabular}{|c|c|c|c|c|c|c|}
\hline \multirow[b]{3}{*}{ Sector } & \multirow{2}{*}{\multicolumn{2}{|c|}{$\begin{array}{l}\text { Percentage change in } \\
\text { world price, } 1985-87\end{array}$}} & \multirow{2}{*}{\multicolumn{2}{|c|}{$\begin{array}{c}\text { Base-year value, } \\
1985 \text { (millions } \\
\text { of dollars) }\end{array}$}} & \multicolumn{2}{|c|}{ Trade elasticities } \\
\hline & & & & & \multirow{2}{*}{$\begin{array}{l}\text { Imports } \\
(\sigma)\end{array}$} & \multirow{2}{*}{$\begin{array}{c}\text { Exports } \\
(\Omega)\end{array}$} \\
\hline & Imports & Exports & Imports & Exports & & \\
\hline Basic metals & 17.7 & 16.4 & 885.8 & 587.0 & 0.6 & 0.6 \\
\hline $\begin{array}{l}\text { Chemicals and } \\
\text { ferrilizer }\end{array}$ & 17.7 & 16.4 & 2.468 .3 & 930.8 & 0.6 & 0.5 \\
\hline Construction & - & 10.7 & 0.0 & $\begin{array}{r}0.0 \\
0.0\end{array}$ & - & 0.3 \\
\hline $\begin{array}{l}\text { Electricity, gas, } \\
\text { and water }\end{array}$ & $\overline{17}$ & $\overline{164}$ & 0.0 & 0.0 & $\bar{a}$ & - \\
\hline Food agriculture & 17.7 & 16.4 & 442.7 & 147.6 & 0.6 & \\
\hline $\begin{array}{l}\text { Food, beverages, } \\
\text { and tobacco }\end{array}$ & 17.7 & 16.4 & 235.0 & 190.7 & 0.9 & 1.2 \\
\hline $\begin{array}{l}\text { Metal products } \\
\text { and machinery }\end{array}$ & 17.7 & 16.4 & $6,724.0$ & 161.5 & 0.6 & 0.6 \\
\hline $\begin{array}{l}\text { Nonmetallic } \\
\text { minerals }\end{array}$ & 17.7 & 16.4 & 236.1 & 23.6 & 0.6 & 2.0 \\
\hline Oil, LNG $^{\mathrm{a}}$ and coal & 27.6 & -31.3 & $1,532.3$ & $13,165.5$ & 0.9 & 0.6 \\
\hline Other mining & 17.7 & 16.4 & 201.4 & 184.0 & 0.9 & 0.6 \\
\hline $\begin{array}{l}\text { Paper and other } \\
\text { industry }\end{array}$ & 17.7 & 16.4 & 348.4 & 40.2 & 0.9 & 2.0 \\
\hline $\begin{array}{l}\text { Public } \\
\text { administration }\end{array}$ & - & - & 0.0 & 0.0 & - & - \\
\hline Services & 17.7 & 16.4 & $5,977.3$ & 596.5 & 0.4 & 0.4 \\
\hline Textiles and leather & 17.7 & 16.4 & 167.3 & 705.5 & 0.9 & 0.6 \\
\hline Trade and storage & 17.7 & 16.4 & 117.6 & $1,357.8$ & 0.4 & 0.4 \\
\hline Traded agriculture & 17.7 & 16.4 & 381.5 & $1,376.5$ & 1.7 & 0.5 \\
\hline Transport & 17.7 & 16.4 & 530.8 & 625.8 & 0.4 & 0.4 \\
\hline Wood and furniture & 17.7 & 16.4 & 4.1 & $1,009.5$ & 0.9 & 0.6 \\
\hline Sum or average & 18.4 & -13.4 & $20,252.6$ & $21,102.5$ & 0.59 & 0.57 \\
\hline
\end{tabular}

- Not applicable.

a. Liquified natural gas.

The PPP calculation does not reflect the sharp deterioration in the international terms of trade experienced during this period. To take this shock into account, we turn to the 1-2-3 model. As in the Cameroon example, we assume that the terms of trade shock was the only one facing the country. Moreover, for Indonesia, we focus only on the movement in oil prices, ignoring movements in other international prices. For 1985 through 1987, available data suggest that Indonesia's average export prices fell by 13 percent (with oil prices dropping by 31 percent), while its average import prices rose by 18 percent (World Bank data).

Table 4 shows the change in the domestic price level $\left(\hat{P}^{d}\right)$ for different values of the CET export and CES import elasticities, using the average price changes cited above and applying equation 16 . The nominal exchange rate is assumed unchanged, and the balance of trade declines by 2.6 percent (measured by $\hat{\lambda}$ ). The equilibrium domestic price movements range from -65 to -14 percent, depending on the elasticities. The middle row and column $(\Omega=0.57$ and $\sigma=$ 
$0.59)$ are reasonable elasticity values for Indonesia and were obtained through a traded-weighted average of the sectoral elasticities presented in table 5 . With these average parameter values, the domestic price is estimated to decline by 26 percent (assuming $\hat{R}=0$ ). Of this 26 percent, 27 percent is due to the terms of trade shock, 2 percent to the change in the trade balance, and -3 percent to the change in world prices.

To facilitate comparison of these results with the PPP model, table 6 summarizes the real depreciation $\left(\hat{R}^{r}\right)$ suggested by the 1-2-3 model, using the formulation of equation 18. Estimates of the real depreciation range from 17 to 68 percent. With average Indonesian elasticities, the 1-2-3 model requires depreciation of the real exchange rate of 29 percent, compared with the constant real rate based on the PPP approach. Of the 29 percent real devaluation, 27 percentage points are due to changes in the international terms of trade, and only 2 percentage points are due to the change in the balance of trade.

Finally, we address the question of how much our results have been affected by the use of an aggregated model. For this purpose we examine the same terms of trade shock using an 18-sector CGE model of Indonesia, a model described in detail in Devarajan and Lewis (1991) and Lewis (1991). Table 5 summarizes the sectoral structure of Indonesian trade, as well as the sector-specific price shocks and the export and import elasticities. The assumption of a fixed nominal exchange rate is not appropriate for Indonesia. The CGE model for Indonesia solves for the nominal exchange rate endogenously, with the aggregate price level set as numeraire. Both models, of course, determine the equilibrium real exchange rate. In the 1-2-3 model, we move to equation 17 , which includes both domestic inflation and the nominal exchange rate.

Table 7 compares the CGE model results with those from the PPP and 1-2-3 models. The CGE model yields a real depreciation of 28 percent, which is quite close to the 29 percent figure yielded by the 1-2-3 model. As with the Cameroon example, the 1-2-3 model performs remarkably well in determining the size of the required real exchange rate adjustment, although without the structural detail provided by the CGE model. Note that the inflation adjustment figures for the 1-2-3 and CGE models are quite close, even though the foreign price move-

Table 6. Equilibrium Real Exchange Rate Depreciation in Indonesia, 1985-87 (percent)

\begin{tabular}{llllll}
\hline \multirow{2}{*}{$\begin{array}{l}\text { Export transformation } \\
\text { elasticity }(\Omega)\end{array}$} & \multicolumn{5}{c}{ Import substitution elasticity $(\sigma)$} \\
\cline { 2 - 6 } & 0.25 & 0.50 & 0.59 & 0.75 & 1.00 \\
\hline 0.25 & 67.7 & 45.1 & 40.2 & 33.8 & 27.1 \\
0.50 & 45.1 & 33.8 & 31.0 & 27.1 & 22.6 \\
0.57 & 41.1 & 31.5 & 29.0 & 25.6 & 21.5 \\
0.75 & 33.8 & 27.1 & 25.2 & 22.6 & 19.3 \\
1.00 & 27.1 & 22.6 & 21.3 & 19.3 & 16.9 \\
\hline
\end{tabular}

Note: Values are the percentage change in the equilibrium real exchange rate caused by an 18 percent increase in import prices, a 13 percent decrease in export prices, and a 2.6 percent decline in the sustainable balance of trade. 
Table 7. Equilibrium Exchange Rate Devaluation, Calculations

for Indonesia, 1985-87

(percent)

\begin{tabular}{lccccc}
\hline & \multicolumn{2}{c}{ Ppp approach } & & \\
\cline { 2 - 3 } & $\begin{array}{c}\text { Dollar } \\
\text { only }\end{array}$ & $\begin{array}{c}\text { Dollar } \\
\text { and yen }\end{array}$ & $\begin{array}{c}1-2-3 \\
\text { model }\end{array}$ & $\begin{array}{c}\text { CGE } \\
\text { model }\end{array}$ \\
\hline Nominal devaluation & 11.5 & 14.6 & 45.4 & 45.4 \\
Differential inflation adjustment & 11.5 & 14.6 & 16.4 & 17.3 \\
Real devaluation & 0.0 & 0.0 & 29.0 & 28.1 \\
\hline
\end{tabular}

Note: For PpP calculations, real devaluation is zero by assumption, and nominal devaluation equals the inflation adjustment. For the 1-2-3 and CGE models, nominal devaluation is the sum of real devaluation and an inflation adjustment, using the same domestic price inflation figure for both (19.5 percent). The price inflation figure is derived from GDP accounts data.

ments are calculated differently. The 1-2-3 world inflation rate comes from equation 17 , where the movement in foreign prices is obtained as a weighted sum of export and import inflation, the weights depending on the average elasticities. The CGE world inflation rate is also a weighted sum of export and import inflation, but with weights based on the base year value of imports and exports. Because trade is nearly balanced and the average elasticities are nearly equal, the weights in each case are approximately the same. Therefore the inflation numbers are quite close.

\section{CONCLUSION}

In this article, we discuss the theoretical and empirical shortcomings of different approaches to computing the equilibrium real exchange rate. We present a small model that distinguishes between imports, exports, and domestic goods and incorporates imperfect substitutability between imports and domestic goods in demand and imperfect transformability between exports and domestic goods in supply. We argue that this 1-2-3 model is an extension of the Salter-Swan model, and that it reconciles the tradable-nontradable goods model with the purchasing-power-parity approach.

We show how the 1-2-3 model can be used to compute the equilibrium real exchange rate when there are changes in the sustainable balance of trade and in international prices. Estimates using this model depart quite substantially from those using the PPP approach, which neglects terms of trade shocks-arguably the main cause of changes in the equilibrium real exchange rate since the 1970s. The results from the 1-2-3 model agree closely with the results from larger computable general equilibrium (CGE) models. The 1-2-3 model estimates of changes in the equilibrium real exchange rate agree closely with those obtained from larger, more elaborate CGE models, such as have been used to analyze issues of structural adjustment in Cameroon and Indonesiä. In practice, using the 1-2-3 model to compute changes in the equilibrium real exchange rate requires little more information than is required to make PPP calculations. 
The 1-2-3 model does require information to calculate two elasticities whose values are difficult to estimate with limited data. And the required real exchange rate depreciation can be quite sensitive to these elasticities. Nevertheless, experience with larger models as well as empirical estimation in some countries helps us narrow the range of values for these elasticities, thereby narrowing the range of estimates of the required depreciation.

\section{REFERENCES}

The word "processed" describes informally reproduced works that may not be commonly available through library systems.

Benjamin, Nancy, Shantayanan Devarajan, and Robert Weiner. 1989. "The 'Dutch Disease' in a Developing Country: Oil Reserves in Cameroon." Journal of Development Economics 30 (1, January): 71-92.

Bhagwati, Jagdish. 1978. Foreign Trade Regimes and Economic Development: Anatomy and Consequences of Exchange Control Regimes. Cambridge, Mass.: Ballinger Publishing Co.

Cavallo, Domingo, and Joaquin Cottani. 1986. "The Timing and Sequencing of Trade Liberalization Policies: The Case of Argentina." World Bank, Country Economics Department, Washington, D.C. Processed.

de Melo, Jaime, and Sherman Robinson. 1989. "Product Differentiation and the Treatment of Foreign Trade in Computable General Equilibrium Models of Small Economies." Journal of International Economics 27: 47-67.

Dervis, Kemal, and Sherman Robinson. 1982. "A General Equilibrium Analysis of the Causes of a Foreign Exchange Crisis: The Case of Turkey." Weltwirtschaftliches Archiv 118 (2): $259-80$.

Devarajan, Shantayanan, and Jeffrey D. Lewis. 1991. "Structural Adjustment and Economic Reform in Indonesia: Model-Based Policies versus Rules of Thumb." In Dwight Perkins and Michael Roemer, eds., Reforming Economic Systems in Developing Countries. Cambridge, Mass.: Harvard University Press.

Devarajan, Shantayanan, and Jaime de Melo. 1987. "Adjustment with a Fixed Exchange Rate: Cameroon, Côte d'Ivoire, Senegal." The World Bank Economic Review 1 (3, May): 447-88.

Devarajan, Shantayanan, Jeffrey D. Lewis, and Sherman Robinson. 1990. "Policy Lessons from Trade-Focused, Two-Sector Models." Journal of Policy Modeling 12 (4): 1-33.

Dixit, Avinash K., and Victor Norman. 1980. Theory of International Trade. Cambridge, U.K.: Cambridge University Press.

Dornbusch, Rudiger. 1987. "Purchasing Power Parity." In John Eatwell, Murray Milgate, and Peter Newman, eds., The New Palgrave: A Dictionary of Economics, vol. 3. London: Macmillan Press, 1987.

Edwards, Sebastian. 1989. Real Exchange Rates, Devaluation, and Adjustment: Exchange Rate Policy in Developing Countries. Cambridge, Mass.: MIT Press.

Hinojosa, Raul, and Sherman Robinson. 1991. "Alternative Scenarios of U.S.-Mexico Integration: A Computable General Equilibrium Approach." Working Paper 609. University of California at Berkeley, Department of Agricultural and Resource Economics. Processed. 
Honohan, Patrick. 1990. "Price and Monetary Convergence in Currency Unions: The Franc and Rand Zones." PRE Working Paper 390. World Bank, Country Economics Department, Washington, D.C. Processed.

International Monetary Fund. 1989, various issues. International Financial Statistics. Washington, D.C.

Kis, Peter, Sherman Robinson, and Laura D. Tyson. 1990. "Computable General Equilibrium Models for Socialist Economies." In L. Bergman, D. W. Jorgenson, and E. Zalai, eds., General Equilibrium Modeling and Economic Policy Analysis. Oxford: Basil Blackwell.

Krueger, Anne O. 1978. Foreign Trade Regimes and Economic Development: Liberalization Attempts and Consequences. Cambridge, Mass.: Ballinger Publishing Co.

Krueger, Anne O., Maurice Schiff, and Alberto Valdés. 1988. "Agricultural Incentives in Developing Countries: Measuring the Effect of Sectoral and Economywide Policies." The World Bank Economic Review 2 (3, September): 255-72.

Lewis, Jeffrey D. 1991. "A Computable General Equilibrium (CGE) Model of Indonesia." Development Discussion Paper 378. Harvard University, Harvard Institute for International Development, Cambridge, Mass. Processed.

Lewis, Jeffrey D., and Shujiro Urata. 1984. "Anatomy of a Balance of Payments Crisis: An Application of a Computable General Equilibrium Model to Turkey, 1978-1980." Economic Modelling 1 (3): 281-303.

Mundlak, Yair, Domingo Cavallo, and Roberto Domenech. 1990. "Effects of Macroeconomic Policies on Sectoral Prices." The World Bank Economic Review 4 (1, January): $55-79$.

Robinson, Sherman, and Laura D. Tyson. 1985. "Foreign Trade, Resource Allocation, and Structural Adjustment in Yugoslavia: 1976-1980." Journal of Comparative Economics 9: 46-70.

Salter, W. E. 1959. "Internal and External Balance: The Role of Price and Expenditure Effects." Economic Record 35: 226-38.

Swan, Trevor. 1960. "Economic Control in a Dependent Economy." Economic Record 36: 51-66.

Williamson, John. 1983. The Exchange Rate System. Cambridge, Mass.: MIT Press.

World Bank. 1989. African Economic and Financial Data. Washington, D.C. 

THE WORLD BANK ECONOMIC REVIEW, VOL. 7, NO. 1: 65-83

\title{
Obstacles to Developing Indigenous Small and Medium Enterprises: An Empirical Assessment
}

\author{
Brian Levy
}

\begin{abstract}
The article reports the results of field surveys conducted in Sri Lanka's leather industry and Tanzania's furniture industry. It outlines an approach to learning how small and medium enterprises (SMEs) perceive the impact of financial, regulatory, technical, marketing, and other input constraints, and to evaluating the results in relation to other empirical indicators. Lack of access to finance emerges as the binding constraint for smaller, less established firms in Sri Lanka and for all of Tanzania's sMEs-not only is informal financing limited for Tanzania's firms, even firms of adequate size and experience have difficulty borrowing from banks, and, if they do borrow, have difficult relations with their lenders. In Tanzania, regulatory and tax constraints appear largest for the smallest firms, declining somewhat as firms grow: because enforcement is comprehensive, the bureaucratic burden of negotiating with government officials is greatest for small firms. By contrast, in Sri Lanka the regulatory burden rises with firm size, because enforcement is more stringent for the larger and more visible firms. Constraints on physical inputs continue to inhibit Sri Lankan SMEs-a legacy of excessive vertical integration by parastatals. Technical constraints are appraised as most significant by relatively educated entrepreneurs with some involvement in high-quality market niches.
\end{abstract}

This article reports on field research on constraints confronting small and medium enterprises (sMEs) in Sri Lanka and Tanzania and draws some lessons for reforms to help develop an efficient indigenous private sector in developing countries. Although the choice of Sri Lanka and Tanzania was dictated by operational considerations, together these countries richly depict the constraints SMEs face in the transition from failed experiments with state control of economic activity to less interventionist economic policies. Other recent World Bank studies have sought to learn what sMes in Ghana, Mali, Malawi, and Senegal perceive as major constraints on operation and expansion; see, for example, Steel and Webster (1990). For some recent surveys of empirical work on SMEs, see Liedholm and Mead (1987), Liedholm (1990), and Schmitz (1982).

Brian Levy is with the Country Economics Department at the World Bank.

(C) 1993 The International Bank for Reconstruction and Development/THE WORLD BANK 


\section{The EMpirical Approach}

Field research was conducted in Sri Lanka and Tanzania in 1989-90. Reforms had been initiated in Sri Lanka in 1977, and by 1990 the embrace of liberal, pro-private sector policies was virtually complete. Tanzania's policy reforms had begun in 1984 and had proceeded only haltingly. Even so, the reforms had eased binding SME constraints of access to foreign exchange and to imported inputs.

\section{Sample Selection}

Firm-level interviews in both countries sought to learn what sMEs viewed as the major constraints on enterprise operation and expansion. All interviews combined open-ended and survey approaches. Interview protocols (revised after the initial interviews) were used to guide the discussion and to gather data usable in quantitative analysis. Because research based on interviews can be expensive, a number of compromises had to be made. Each of these compromises implies a need for caution in generalizing from the results.

The first compromise was that the sample size was small and the measures were often qualitative; thus the data lend themselves more to cross-tabulation than to rigorous tests of hypotheses. The second was that the interviews were conducted only in the two capital cities and their environs, so the results may not apply to smaller towns or to rural areas. The third was that the surveys focused on a narrow group of subsectors in which the country had some potential for comparative advantage, small-scale entry was possible at the smallest scale, and enterprises could expand incrementally to quite large size. This subsectoral approach enables the interviewer to learn in some detail about the setting in which the SMEs operate, and penetrate beyond superficial responses. The risk is that results might not apply broadly, and there would be sharp differences in constraints across sectors. In practice, as the empirical analysis below reveals, input constraints, regulations targeted to individual sectors, and technical and marketing constraints tend to be sector-specific, whereas constraints associated with imperfections in the market for finance and with industry-wide regulations are likely to be similar across sectors.

To balance the strengths and weaknesses of subsectoral and broadly based approaches, interviews were conducted in three subsectors in each countryleather products, ceramics, and gemstone calibration in Sri Lanka, and furniture, construction, and horticulture in Tanzania. For Sri Lankan leather products and Tanzanian furniture, the enterprise sample was large enough to permit the quantitative analysis reported below. Analysis in the remaining subsectors was qualitative, but suggested that the impacts of financial and (non-sectorspecific) regulatory constraints were broadly similar to those observed in the sectors analyzed in more detail. 


\section{Leather Products Enterprises in Sri Lanka}

As of mid-1990, Sri Lanka's leather industry comprised a diverse array of participants, both upstream and downstream. Upstream there were a dozen or so tanners. The state-owned Leather Corporation (accounting for about 35 percent of the 11 million square feet of leather tanned each year) was the largest, followed by two midsized firms (together accounting for an additional 35 percent) and an additional nine, smaller, private tanners. Downstream enterprises, most of which produced footwear for the local market, comprised three major suppliers (the multinational enterprise Bata, a downstream division of the Leather Corporation, and a private Sri Lankan firm), some medium-sized enterprises (some producing for their own retail outlets, and others engaged in subcontracting), and a host of smaller producers, including thousands of cobblers. Two enterprises-one Japanese, the other Korean-exported leather footwear from Sri Lanka's export processing zone. The subsector included producers of other leather products, largely for exports and the local tourist market; these enterprises varied in size from quite large operations to SMEs with fewer than 30 employees. Interviews were conducted with the Leather Corporation, two private tanners, Bata, and 38 locally owned producers of leather products and footwear in greater Colombo.

Sri Lanka's competitive advantage in the leather industry lies in an abundant supply of labor skilled in the fabrication of high-value added, labor-intensive products. Exports of these goods-by the two enterprises located in the export zones, by two other large producers, and by a half dozen or so sMEs-accounted for more than 90 percent of Sri Lanka's leather exports in 1987. However, with total leather exports under $\$ 15$ million, Sri Lanka had barely begun to tap its export potential. Aside from the two firms in the export zones, no Sri Lankan producer had yet begun to export footwear, although Bata apparently was beginning to explore export markets, and had set an export target of 10 percent of total sales by 1992 . The analysis that follows identifies some of the reasons for this limited export performance.

\section{Furniture Enterprises in Tanzania}

Field research on Tanzania's furniture industry concentrated on Dar es Salaam and its environs. At the time of the interviews, the industry comprised five medium-to-large enterprises whose owners were of Indian origin (or-in one case-an expatriate European) and that employed up to 200 workers each; five to ten medium-sized firms (also Indian-owned); about half a dozen longestablished, indigenously owned small-to-medium ventures; and hundreds of indigenous enterprises that entered the industry in the 1980s, apparently with some acceleration in entry since the initiation of structural adjustment reforms in 1985. Some of the newer, indigenous SMEs had grown quite fast and at the time 
of the interviews employed up to 70 workers. Twenty-four firms were interviewed, including three that were medium-to-large.

Tanzania's furniture enterprises served submarkets that ranged from largevolume orders for government agencies and the export of processed wood products at the top end of the market, to roadside sales of household furniture at the bottom end. Between these extremes, firms produced furniture for sale in their own retail showrooms, supplied high-quality custom-designed furniture to higher-income consumers, and produced household furniture on tender to government agencies and parastatals (the agencies, in turn, distributed the furniture as a fringe benefit to higher-level employees). Interviews uncovered quite substantial mobility among submarkets: seven indigenous SME interviewees won their first tenders to supply government agencies in the $1980 \mathrm{~s}$, all but one winning their first tenders in the two years prior to the interviews. Although very few retailers purchased from independent manufacturers for subsequent resale, at least one expanding enterprise established a makeshift showroom some distance from the workshop. One reason for the absence of intermediation at the retail level may be the prevailing sales tax regime, which treated a sale from manufacturer to retailer and then from retailer to final customer as two, separate taxable transactions, but a sale from a manufacturer through his own showroom to a final consumer as only one transaction.

Some larger enterprises were moving from the midrange of the market to the top end. One enterprise had recently abandoned furniture manufacture for the production for export of parquet flooring and other wood products; a second enterprise had reduced the share of wood furniture in total sales from 50 percent to 10 percent and had shifted into metal office furniture for the domestic market and exports of other wood products. So, rather than being "crowded out," new market opportunities continually emerged for expanding SMEs.

\section{An Overview of the Constraints}

Table 1 groups into four categories the constraints on expansion identified by survey respondents in Sri Lanka's leather SMEs and Tanzania's furniture SMEs: financing constraints; regulatory constraints; constraints on physical, technical, and marketing inputs; and cost constraints. Entrepreneurs were asked to rank each constraint on a scale of 1 to 5 according to its degree of severity. They were encouraged to score across the full 1-5 range, and special care was taken to ensure that there was at least some dispersion.

The rankings in table 1 provide information on the respondents' perceptions of both the absolute and the relative severity of individual constraints. One entrepreneur might rank the entire set of obstacles within the 1-3 range (signifying a judgment that the absolute severity of even the most binding constraint is only moderate), and another-with identical perceptions of the relative severity of the obstacles-might rank the entire set in the 3-5 range. Because nothing useful for policy can be learned from differences among entrepreneurs in their perceptions of the absolute magnitude of obstacles, the scores were normalized 
Table 1. The Constraints on Expansion Identified by Leather SMEs in Sri Lanka and Furniture SMEs in Tanzania (average normalized score)

\begin{tabular}{lll} 
Constraint & $\begin{array}{c}\text { Sri Lankan } \\
\text { SMEs }\end{array}$ & $\begin{array}{c}\text { Tanzanian } \\
\text { SMEs }\end{array}$ \\
\hline Lack of access to finance & 0.58 & 0.97 \\
Regulatory constraints & & \\
$\quad$ Potential changes in tax status & 0.25 & n.a. \\
Bureaucratic procedures & 0.09 & 0.67 \\
Labor regulations & 0.07 & n.a. \\
Policy uncertainty & 0.10 & n.a. \\
Lack of access to industrial sites & n.a. & 0.64 \\
Constraints on access to nonfinancial inputs & & \\
Physical inputs & & \\
Lack of access to materials & 0.41 & n.a. \\
Lack of access to spare parts & n.a. & 0.38 \\
Lack of access to wood & n.a. & 0.16 \\
Lack of access to equipment & n.a. & 0.26 \\
Technical and marketing inputs & & \\
Scarcity of competent workers & 0.21 & 0.14 \\
Lack of technical skills & 0.19 & 0.11 \\
Not enough domestic buyers & 0.11 & 0.28 \\
Cost constraints & & \\
Cost of finance & 0.73 & 0.72 \\
Cost of materials & 0.61 & 0.63 \\
Cost of equipment & 0.49 & 0.58 \\
\hline
\end{tabular}

n.a. Not applicable.

Note: Survey respondents' scores were normalized along a scale of 0 to 1 , in which constraints ranked close to 0 are least severe and those ranked close to 1 are most severe. Figures are averages for all firms surveyed. The number of firms in the sample was 38 for Sri Lanka and 20 for Tanzania, but one firm in Tanzania did not provide usable responses to the relevant questions.

along a scale of 0 (least severe) to 1 (most severe), and the normalized scores for each constraint were averaged across entrepreneurs. The normalization, aggregation, and averaging of individual scores provided cardinal estimates of the severity of the constraints in relation to one another for a given country and subsector: an average score of 1 implies that the relevant constraint was ranked most binding and a score of 0 that it was ranked least binding by all sample firms.

Before reviewing and interpreting the results for each constraint group, three preliminary points need to be made. First, the entrepreneurs' perceptions as to the impact of different constraints represent an important-but not definitivesource of information. To cross-check, the field research examined other, complementary data sources. By and large the results were mutually reinforcing, as the analysis that follows makes clear.

Second, although all of the various cost constraints scored relatively high for both industries, they will not receive any further attention here, because their high scores need not signal any government or market imperfection. On the 
contrary, SMEs' reports of high prices on inputs can be interpreted as a signal of significant competitive pressure and an associated squeeze on profits, both of which are desirable if they induce enterprises to innovate and become more efficient.

Third, there is much more variation in the average scores for individual constraints for Tanzania than for Sri Lanka. And the three most binding noncost Tanzanian constraints (lack of access to finance, lack of access to industrial sites, and bureaucratic procedures) all score higher than the most binding (noncost) Sri Lankan constraint (lack of access to finance). As will become apparent below, these differences reflect the contrast between the Tanzanian environment, which is characterized by a few, rigidly binding nonprice constraints inhibiting SME expansion, and the significantly less restrictive environment for sMEs in Sri Lanka.

\section{Financial Access Constraints and Reforms}

As the constraint scores in table 1 reveal, lack of access to finance emerged as the leading (nonprice) constraint on SMEs in both Sri Lanka and Tanzania, albeit with a significantly higher absolute score in Tanzania. Lack of access to finance was identified as the most severe constraint on expansion by 18 of 19 Tanzanian furniture firms, accounting for the score of 0.97 (out of a feasible maximum of 1). Yet evidence of financing constraints need not imply that there exist imperfections in financial markets that warrant attention by policymakers; there are some financially constrained enterprises to which it would be imprudent for any financial intermediary to lend. Additional empirical analysis is required to evaluate whether the constraint scores signify a serious market failure.

\section{Sources of SME Finance and Their Difficulties}

Table 2 summarizes the sources of finance for the Sri Lankan and Tanzanian SMEs. Consistent with the pattern observed worldwide, the entrepreneurs' own savings represent a dominant source of SME finance in both countries; all but one

Table 2. Sources of Finance for Leather SMEs in Sri Lanka and Furniture SMES in Tanzania

(percentage of sample firms that obtained finance from each source)

\begin{tabular}{lcc} 
Source of finance & $\begin{array}{c}\text { Sri Lankan } \\
\text { leather SMES }\end{array}$ & $\begin{array}{c}\text { Tanzanian } \\
\text { furniture SMEs }\end{array}$ \\
\hline Own savings or retained earnings & 100.0 & 95.0 \\
Family & 34.2 & 25.0 \\
Partners & 2.6 & 45.0 \\
Formal financial institutions & 42.1 & 45.0 \\
Informal financial institutions & 28.9 & 0.0 \\
Trade credit & 28.9 & 0.0 \\
\hline
\end{tabular}

Note: The number of firms in the sample was 38 for Sri Lanka and 20 for Tanzania. 
Table 3. Percentage of SMEs that Ever Received Formal Bank Credit, by Size and Age of Firm

(number of firms is in parentheses)

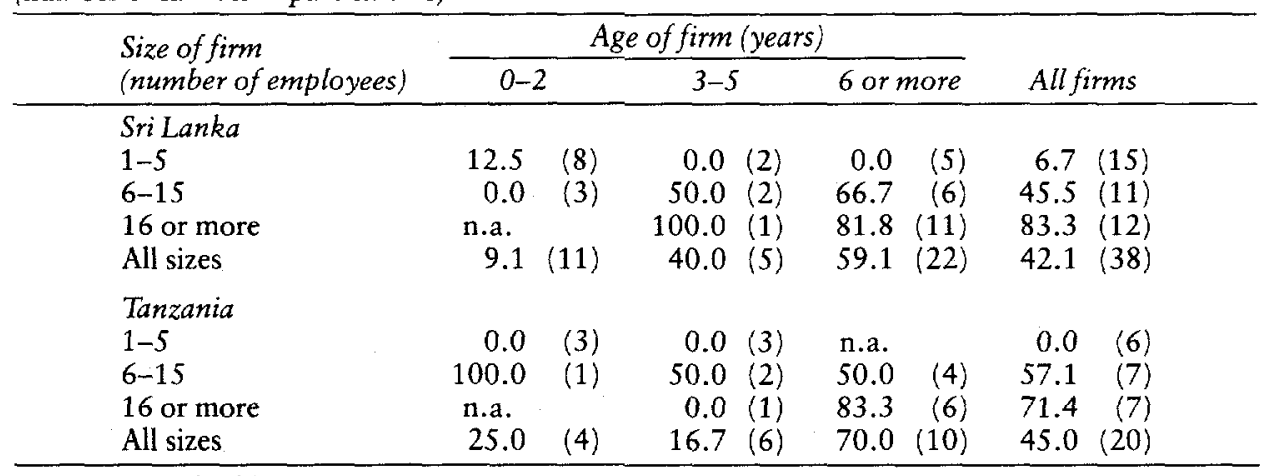

n.a. Not applicable.

of 58 SMEs drew on the savings of the proprietor. Trade credits and informal financial intermediaries were each used by about 30 percent of the Sri Lankan firms sampled, also paralleling patterns observed worldwide. Interestingly, 12 firms ( 32 percent of the sample for Sri Lanka) reported using at least one of these sources of informal credit prior to securing finance from the formal banking sector.

By contrast, none of the indigenous Tanzanian enterprises used either trade credits or informal intermediaries. (The picture is quite different for Tanzania's entrepreneurs of Indian origin, who apparently have well-developed informal mechanisms of financial intermediation.) Widespread use of partnerships in Tanzania could represent a substitute channel of informal financing. The absence of trade credit can in part be accounted for by Tanzania's pervasive banking inefficiencies (on which there is more below) and a legal system that affords only protracted and uncertain recourse (Biggs 1988; Stone, Levy, and Paredes 1992). The absence of other informal lending mechanisms for indigenous enterprises signals a gap evident throughout East Africa.

As table 2 shows, more than 40 percent of firms in the two countries enjoyed access to formal finance. Table 3 disaggregates all Sri Lankan and Tanzanian SMEs and those with access to formal bank loans by the size and age of the enterprises. In Sri Lanka there were eighteen firms that had five or fewer employees or were less than three years old; only one of these had access to formal bank credit. Of the seven SMEs in Tanzania with five or fewer employees or that were less than three years old, only one had access to formal bank credit. These patterns are consistent with the finding that incentives for formal financial institutions to lend to SMEs are weak (Little, Mazumdar, and Page 1987). Because loan sizes are small, the costs of processing are high in relation to loan amounts. In addition, the track record and reputation of a putative SME borrower is likely to be limited (as is the system of financial accounting), which adds to the costs of 
loan processing. And the probability of failure is high even for well-conceived new ventures. Only after an SME has some record of success is it generally able to tap into the resources of the formal financial system.

Within the pool of "qualified" enterprises (those with more than five employees and at least three years of operation), coverage was similar in the two countries. Loans had been extended to 75 percent of such firms in Sri Lanka and about 60 percent of such firms in Tanzania. Yet there were sharp differences between the countries in the characteristics of qualified SMEs without loans. Four of the five qualified Sri Lankan SMEs without loans reported that they were not financially constrained and had no interest in borrowing from banks. Each of these four SMEs recorded 0 as their normalized score for access to finance as a constraint on expansion.

By contrast, all five of the qualified Tanzanian firms without loans identified lack of access to finance as among their leading constraints. The constraint score for lack of access to finance was the maximum possible-1-1-for four of the five firms, and 0.75 for the fifth. Three of the five were among the most successful and rapidly expanding sMes sampled; all three had made initial approaches to the banks for loans, but without success. According to interviewees, loan applicants were required to provide fixed property as collateral. However, because the banks refused to recognize leasehold land title (the only form of land title permitted in Tanzania) as collateral, individuals could borrow no more than the value of the physical structures they owned. In addition, applicants had to provide detailed feasibility studies of their projected investments (even for overdraft facilities), as well as detailed financial statements. Even with collateral, feasibility studies, and financial statements in hand, firms reported that the processing of loan applications took an average of six months and might still require side payments as a precondition for processing.

All 16 of the Sri Lankan borrowers sampled appeared satisfied with bank service, but 8 of the 9 Tanzanian SMEs with loans complained bitterly about their relationship with the banks. The difficulties of three of the firms were related to the precarious financial condition of the enterprises themselves. But of the remaining six (healthy) firms, two reported that the bank disrupted the enterprise's business plan by imposing its own arbitrary loan ceiling even though all prerequisites for a larger loan had been fulfilled. Two others reported that their banker temporarily shut down their overdraft facilities over disputes that were peripheral to the lending relationship itself. In all, Tanzania's sMEs felt they were viewed by banks as unwelcome supplicants, to be dealt with only so long as stringent conditions were met and, even then, only so long as the enterprise respected without question the omniscient authority of the lending agency.

\section{Enhancing Access to Finance}

Sri Lanka offers a useful guide to the features of a formal banking sector that can lend effectively to SMEs (see Webster 1991). Some of these features are the familiar virtues of a well-functioning financial system: competition among inde- 
pendent banks for borrowers (Sri Lanka has more than 30 independent financial institutions), positive real interest rates, and determined efforts at collecting outstanding loans (even with ongoing civil unrest, the recovery rate of Sri Lankan banks for loans to SMEs has been in the 75 to 90 percent range).

But other features of formal bank lending in Sri Lanka are less consistent with laissez-faire dogmas of financial sector reform. The bulk of SME lending has come from targeted, World Bank-supported SME loans. Although both public and private institutions participate in the Bank-supported project, the largest lender has been the state-owned Bank of Ceylon, followed by the (also stateowned) People's Bank. Furthermore, although there is little difference in the recovery rates of the public and private banks, the public banks have more aggressively sought out borrowers that do not ordinarily have access to formal credit than have the private banks, which have serviced only the most obviously creditworthy SME borrowers. Finally, the Central Bank of Sri Lanka operates a credit guarantee scheme that provides partial coverage for SME lending and apparently was widely used at least in the initial years of SME lending. The Sri Lankan experience suggests it is premature to conclude that the unsupported, market-driven provision of nontargeted credit by competing private banks will be sufficient to secure access by SMEs to formal finance.

\section{Regulatory CONSTRAINTS AND Reforms}

Table 1 disaggregates Sri Lanka's regulatory constraints, separating labor and tax regulation from "bureaucratic procedures" (which includes local licensing and relations with public utilities). Access to adequate industrial premises is not included in the category of bureaucratic procedures; although scattered anecdotal information suggests that this lack of access might indeed represent a constraint for some SMEs, the Sri Lankan survey was not implemented in a way that could systematically shed light on the issue. Scores are relatively low for all three Sri Lankan regulatory constraints.

The Tanzanian firms reported regulatory constraints to be significant obstacles to expansion; scores were 0.64 and 0.67 , respectively, for lack of access to industrial sites and bureaucratic procedures. The category "bureaucratic procedures" subsumes the relations of Tanzanian SMEs with a range of regulatory authorities, including sales and income tax authorities, town councils (which issue licenses), public utilities (power, telephone, and water), the National Provident Fund, and the Labor Ministry.

\section{Regulatory Constraints and Firm Size}

Table 4 decomposes the constraint scores by the SME's size and (for Sri Lanka) legal status and uncovers systematic variation in the impact of regulation among SMEs and across the two countries. In Sri Lanka the scores rise with firm size, the rise being somewhat larger for the tax constraint than for the others. In Tanzania the scores are largest for the smallest firms. To account for these divergent 
Table 4. Average Normalized Scores for Decomposed Regulatory Constraints by SME Size and Legal Status (number of firms is in parentheses)

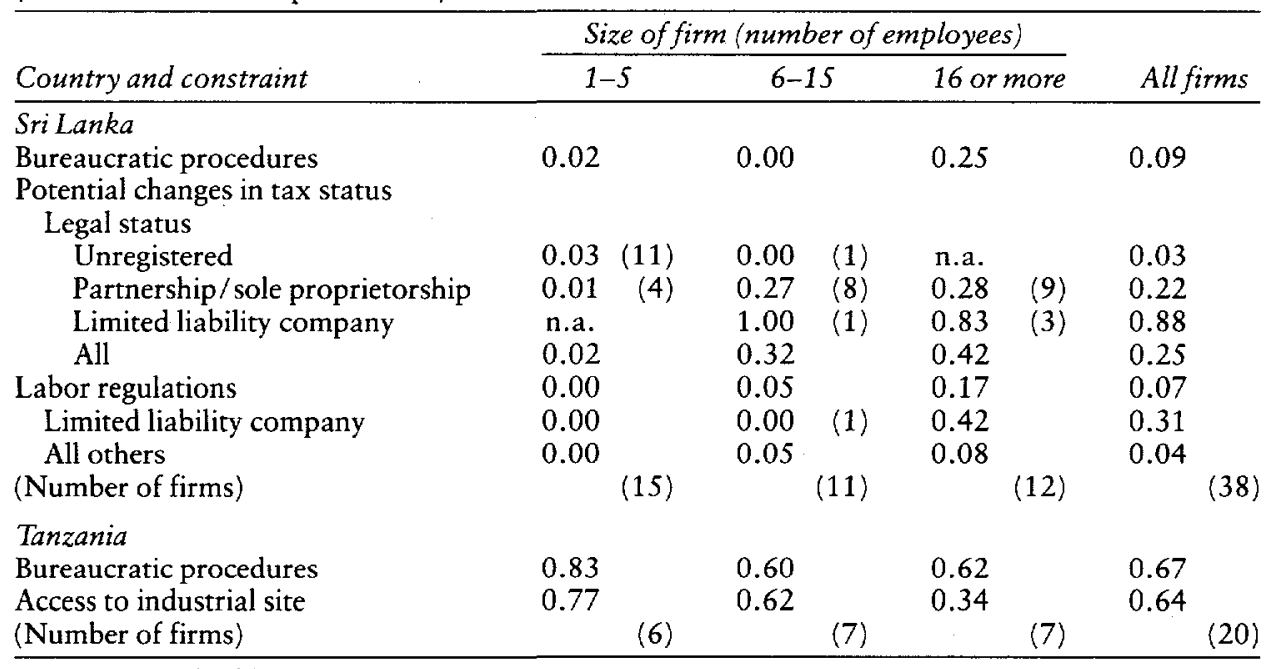

n.a. Not applicable.

Note: The figure in parentheses is the number of firms in that category, if it is less than the total number of firms of that size. Survey respondents' scores were normalized along a scale of 0 to 1 , in which constraints ranked close to 0 are least severe and those ranked close to 1 are most severe. Figures are averages for all firms surveyed in each category. The number of firms in the sample was 38 for Sri Lanka and 20 for Tanzania.

patterns, it is useful to distinguish among three distinct burdens-fiscal, bureaucratic, and threshold.

The fiscal burden is the amount of tax that firms actually pay. The bureaucratic burden is the cost to SMEs of dealing with government agencies, importantly the opportunity cost of entrepreneurial effort diverted away from wealthgenerating activities. The size of the bureaucratic burden is inversely proportional to the agencies' efficiency. Because governments presumably do not impose bureaucratic tasks only to torment entrepreneurs, the bureaucratic burden is produced jointly with the fiscal burden-or jointly with some other public task. It is likely to be disproportionately large for the smallest enterprises-in part because its fixed-cost elements are invariant with firm size, and in part because large, but not small, enterprises can hire managers to handle dealings with government officials. Even as a fixed cost, the bureaucratic burden can inhibit the expansion of operating enterprises that are too small to hire a manager. With entrepreneurship complementary to other inputs in production, a reduction of bureaucratic costs would free up the entrepreneur's time and lead to a downward shift of both fixed and variable cost schedules. The threshold burden is the discontinuity in the structure of costs that results. when some fiscal or bureaucratic burden is imposed only on firms above a minimum size. This discontinuity can lead some firms to rein in expansion-or to expand ineffi- 
ciently by creating quasi-independent enterprises, each smaller than the threshold at which the tax and regulatory requirements are imposed.

Regulatory constraints and firm size in Sri Lanka. In Sri Lanka the threshold burden accounts for the increase with firm size in the scores in table 4 for tax and labor regulation constraints. The increase with firm size in the constraint score for bureaucratic procedures is the result of administrative obstacles to exporting-the average constraint score was 0.6 for the five exporting firms (all in the largest category) but 0.0 for the remaining seven larger enterprises.

Taxes on manufacturers of footwear and leather products are relatively high: turnover taxes of 15 percent of gross revenues, and a tax of 33 to 50 percent on net income. (Officials at the Ministry of Finance reported that the 15 percent rate had recently been increased to 20 percent; even so, interviewees continued to report that they were subject to a 15 percent rate.) In practice, interviewees of all sizes and legal statuses conceded that their tax payments were substantially below the formally mandated levels. Unregistered firms paid no taxes. Where partnerships and sole proprietorships were officially registered, they were not required to maintain accounts; consequently they enjoyed significant discretion as to their declared levels of revenue and profits.

Interviewees volunteered that enterprise size was an important determinant of how thoroughly they might be investigated by the tax authorities. Limited liability companies have less room for maneuver, because they must maintain audited accounts. But even these companies implied in interviews that a combination of a low profile and creative accounting could help to limit their tax burden. As table 4 suggests, the increased visibility of limited liability companies also makes them potential targets of enforcement of labor regulations. In all, the field research suggests that as Sri Lankan enterprises grow (or shift to limited liability status) they become vulnerable to large increases in tax and to other regulatory strictures. As a result, many entrepreneurs rationally limit expansion. One important exception is expansion into export markets, where earnings presently are tax free.

Regulatory constraints and firm size in Tanzania. As in Sri Lanka, Tanzania's formal tax and regulatory requirements are demanding. However, unlike Sri Lanka, there is no threshold burden, because enforcement is comprehensive, albeit with pervasive lubrication and renegotiation of formal obligations. In Tanzania the bureaucratic burden (enterprise licensing and taxation) imposes substantial entry and expansion-deterring costs on all enterprises, having an especially severe impact on the smallest firms.

Irrespective of size, all Tanzanian furniture enterprises must be licensed by local authorities and are liable for very substantial payments of taxes. Enterprises with fewer than ten employees need a trading license; enterprises with more than ten employees and enterprises that sell to government agencies need a business license. The sales tax on furniture, payable by manufacturers (and 
again by retailers if they operate independently of the producers), is formally set at a rate equal to 25 percent of sales revenue; income taxes are set at 50 percent of enterprise profits. In practice, all interviewees were licensed to operate by the Dar es Salaam City Council. Similarly, even the smallest furniture enterprises in the sample were regularly held liable for tax payment.

The combination of cumbersome and punitive formal tax and licensing requirements and ubiquitous enforcement create substantial opportunities for officials to extract side payments from even the smallest Tanzanian sMEs. Licenses must be renewed annually. Although the fee is modest and is calculated on a sliding scale according to the size of the enterprise, each renewal is dependent on a host of prior clearances. In the best of circumstances, obtaining clearances and renewal eats into the scarce time of the proprietor. In circumstances in which not all clearances have been obtained, the proprietor is at the mercy of the licensing official. Although incomplete compliance has not been used to obstruct entry or to shut down enterprises, it is a vehicle for officials to extract side payments. Hence 7 of 13 interviewees reported that "lubrication" is needed each year to complete license formalities.

Side payments also are ubiquitous in the implementation of tax laws: only 1 of 13 firms characterized the system of tax collection (of both sales and income taxes) as legitimate; the remaining 12 firms confirmed instead that lubrication is pervasive. Because sales taxes are legally payable on a monthly basis, tax officials can visit enterprises and "negotiate" their tax burden 12 times annually. In practice, the number of negotiations is somewhat fewer: the number of sales tax visits to interviewees over a 12 -month period ranged from a low of two to a high of ten, the average being five a year. Although income tax is payable annually, individual tax assessors can reexamine the accounts of any enterprise at any time on the grounds that inaccurate information has been filed-hence a reported average of two visits a year from income tax officials.

\section{Reforming the Regulatory and Tax Regime}

A well-functioning regulatory and tax regime is characterized by a minimum of bureaucratic requirements and by transparent, moderate obligations imposed across a broad spectrum of enterprises. Where the regime falls short of these desiderata, interactions among the fiscal, bureaucratic, and threshold burdens can offset the most egregiously harmful effects. So, in circumstances such as Tanzania's, where an excessive fiscal burden is offset by pervasive lubrication, the environment for SMEs could be worsened by introducing measures to make regulatory and tax enforcement transparent-thereby exposing SMEs to their full (exorbitant) tax obligations. Conversely, moves in Sri Lanka toward universal coverage would eliminate the threshold burden, but replace it instead with a new bureaucratic and fiscal burden for the smallest enterprises.

Given these interactions, regulatory and tax reform needs to proceed simultaneously on four fronts. First, the prevailing web of regulations should be 
scrutinized, and those that serve no social purpose should be eliminated. Second, where formal tax obligations are too high, they should be reduced. Third, measures should be taken to secure increased transparency of the regulatory and bureaucratic apparatus. Fourth, in parallel with fiscal and bureaucratic reform, decisions should be made on the appropriate coverage of tax and regulatory obligations.

How universal should coverage be? One common argument is that coverage should be wholly universal as a way of eliminating the threshold burden. However, universal coverage would transform the threshold burden from one that inhibits expansion into one that inhibits entry, and the effects would be equally pernicious-if less visible. A second argument is that universal coverage (especially of tax obligations) would broaden the revenue base and thereby permit lower tax rates and less disincentive to growth by taxpaying enterprises. The difficulty is that any new fiscal burden necessarily brings with it a corresponding bureaucratic burden. And universal coverage would extend this burden to small firms-precisely those firms for which the effects are most harmful.

Two implications follow as to the appropriate extent of coverage. First, the case for extending the regulatory net to encompass all enterprises is unambiguous only if the implausible assumption that bureaucracy is frictionless is a given. Put differently, the presence of "informal" firms may not only be a symptom of some underlying policy distortion, but may also signify a wise recognition that some costs of regulation fall disproportionately on the smallest enterprises. Second, there is no single optimal firm size below which tax and regulatory obligations should be excused. Rather, the reach of the regulatory net should vary with the administrative capabilities of individual countries: the weaker a country's administrative capability is, the narrower the reach should be.

In both Sri Lanka and Tanzania the first task is to eliminate regulations that serve no useful social purpose. Subsequently, the agendas for regulatory and tax reform are entirely different in the two countries. In Tanzania, the priority for reform should be to eliminate the bureaucratic and fiscal burdens on the smallest enterprises by exempting them from regulatory and tax obligations. As a secondary measure, more transparent administrative procedures should be introduced; even with lower tax rates, this last measure could increase the fiscal burden for taxpaying firms. In Sri Lanka the priority should be to reduce taxes and the associated fiscal burden on large enterprises and thereby to reduce the disincentives for formality. To maintain the level of tax revenues, this reduction needs to be accompanied by a broadening of the reach of the tax and regulatory apparatus, thereby imposing new fiscal and bureaucratic burdens on previously informal SMEs. Even subsequent to reform, the smallest Sri Lankan firms should remain outside the regulatory and tax net. Because Tanzania's bureaucracy is less efficient than Sri Lanka's, the reach of the regulatory and tax apparatus should extend to smaller enterprises in Sri Lanka than in Tanzania-precisely the reverse of what is now the case. 


\section{Constraints on Physical Inputs and Reforms}

Unlike regulatory or financial constraints, constraints in access to physical inputs tend to be sector-specific. Therefore, in addition to leather in Sri Lanka and furniture in Tanzania, this section will draw on the surveys of the gemstone calibration sector in Sri Lanka and the construction sector in Tanzania.

\section{Constraints on Pbysical Inputs in Sri Lanka}

For the 15 leather SMEs in Sri Lanka with five or fewer employees, the average score for constraints on physical inputs was a low 0.16 , reflecting the firms' willingness to make do with odd lots of low-quality leather. The average for the 23 remaining (larger) enterprises was 0.55 . Indeed, only 17 percent of firms with more than five employees reported that there was sufficient leather of adequate quality available.

Underlying the high constraint scores are some serious imperfections in Sri Lanka's market for leather. Historically, the expansion of footwear and leather products has been tied to the expansion of local tanning-despite a manifest absence of any comparative advantage in tanned leather. Prior to 1983 , this policy took the form of indiscriminate support for the state-owned Leather Corporation, which was afforded preferential access to local hides, was provided a veto on the entry of potential private competitors, and was protected from foreign competition via a bar on imports. Furthermore, the corporation channeled two-thirds of its production to its own downstream footwear and leather products divisions. After 1983 the restrictions on entry and on access to hides and imported leather were liberalized, but a 60 percent nominal tariff was imposed on leather imports. Because of a 200 percent export tax on raw hides, the effective subsidy for tanners was substantially in excess of 60 percent. Interestingly, none of the sMEs interviewed reported that they used imported leather, raising the possibility that nontariff obstacles to the importation of leather continued to exist. Although some private tanners started up new businesses, most used their leather in their own downstream operations or sold on contract to two leading private producers of footwear. Only 25 to 30 percent of domestically tanned leather was sold at arm's length-that is, through more-or-less anonymous market transactions-to independent producers.

Although the imperfections detailed above are specific to leather, lack of access to materials emerged also in Sri Lanka's ceramics and calibrated gemstone sectors as leading constraints on SME expansion. This conclusion is a qualitative one, because the number of SMEs surveyed in the two sectors was too small for quantitative constraint scores to be useful. The state-owned Ceramics Corporation has a legal monopoly to mine the inputs for ceramics and has used that monopoly to shape the structure of the industry in favor of large enterprises. The State Gem Corporation controls both gemstone exports and imports of uncut stones for calibration and reexport. It regulates in a way that imposes a disproportionately severe administrative burden for smaller enterprises involved 
in the export of calibrated gemstones, especially new entrants. One sME exporter whose experience apparently is not atypical reported that he personally spends two days processing the shipment of an export order and three days processing the clearance requirements prior to receipt of a parcel of gemstones sent by a foreign buyer on a no-foreign-exchange basis for calibration and reexport. In a typical month, he reported, he has no alternative but to devote fully 50 percent of his time to overcoming bureaucratic hurdles set up by the State Gem Corporation and by Customs (which operates a parallel apparatus to regulate international trade in gemstones).

\section{Constraints on Physical Inputs in Tanzania}

In table 1 the low constraint scores reported by Tanzanian SMEs for lack of access to equipment, spare parts, and wood signify the existence of relatively well-functioning input markets for producers of furniture. Input markets did not operate as well in Tanzania's construction industry, where lack of access to equipment was identified as the most binding nonprice constraint after access to finance and where lack of access to building materials also was reported as a significant obstacle. Even so, both construction and furniture firms reported that problems of access to physical inputs declined between the time of entry and of the interviews-most likely a result of the greater availability of imported items subsequent to adjustment reforms.

The constraint scores (calculated from a sample of 14 construction firms) for lack of access to equipment and lack of access to building materials as obstacles to expansion were 0.71 and 0.51 , respectively; their respective scores as obstacles to entry were 0.94 and 0.86 , the leading and second constraints at entry. For the furniture firms, the scores for lack of access to spare parts and to equipment as constraints on entry were 0.49 and 0.45 , respectively.

\section{Potential Reforms to Ease Constraints on Physical Inputs}

By the time of the interviews, trade policy reforms in both countries had eased the most egregious constraints on access to imported inputs. Trade policy aside, the Sri Lankan research in particular points to another relevant constraint: in all three sectors a dominant state-owned enterprise has directly or indirectly promoted the emergence of large-scale, vertically integrated operations and thereby shaped industrial organization in a way that discriminates against SMEs. The question arises whether ongoing efforts at privatization (in Sri Lanka and elsewhere) can be carried out in a manner that redresses this bias.

More attention should be paid to how privatization could vertically restructure industry in a way that substitutes more-or-less arm's length transactions for hierarchical relationships within integrated firms. Vertically integrated ties established to take advantage of transactional or technological efficiencies of integration or to capture economies of scope should not be disrupted. But vertical integration that emerged arbitrarily as a result of the decisions of state-owned entities, that is no more (although sometimes perhaps no less) efficient than 
arm's length arrangements, and that inhibits the participation of sMEs should not be maintained. Levy (1991a and 1991b) illustrates how the same industries have entirely different patterns of vertical integration in Korea and Taiwan.

\section{Technical and Marketing Constraints and Reforms}

The scores in table 1 for lack of technical skills, scarcity of competent workers, and not enough domestic buyers are low for both Sri Lanka and Tanzania. However, sample firms often evaluated the obstacles in relation to their existing markets, even though the relevant constraints are those that enterprises confront in relatively demanding markets.

\section{The Impact of Market and Entrepreneur Characteristics on Technical and Marketing Constraints}

Perceptions of technical and marketing constraints might be hypothesized to vary according to both the (market-driven) price and quality requirements of the specific market niches that enterprises seek to serve and the (entrepreneurdriven) ambition and market awareness of the enterprise proprietors. As table 5 summarizes, scores for lack of technical skills indeed vary systematically according to the size of the enterprise, the entrepreneur's education, and the quality of the market niche served.

Reflecting overall differences between the two countries in levels of education, interviewees in Sri Lanka considered entrepreneurs with 13 or more years of schooling to be educated, whereas interviewees in Tanzania considered entrepreneurs with 10 or more years of schooling to be educated. As for the classification of market niches, Sri Lankan enterprises were classified as serving a high-quality niche if they subcontracted to Bata or the second largest private producer and distributor of footwear (there were six firms in this category); if they had made some effort to export (five firms); or if they sold their products through established, relatively high-volume and high-quality retail footwear outlets (four firms). The remaining 22 enterprises in the sample-including nine enterprises with five or fewer workers that sold all of their output directly from their workshops-were classified as serving low-quality niches. The Tanzanian enterprises serving high-quality niches were defined as those that sold furniture to government agencies (there were ten firms in this category) or through retail outlets that were physically independent of the workshop (all four firms in this category also sold to the government); the remaining nine (low-quality niche) firms all sold their entire output directly from their workshops.

Most clearly for Sri Lanka, the sample enterprises fall overwhelmingly into one of two quite distinct groups: educated entrepreneurs that employ more than five workers, have some involvement in high-quality market niches, and appraise technical constraints as quite significant; and uneducated entrepreneurs with 15 or fewer employees, no involvement in high-quality market niches, and no perception that weak technical capabilities limit their expansion efforts. 
Table 5. Average Normalized Scores for Lack of Technical Skills for SMEs in Sri Lanka and Tanzania

(number of firms is in parentheses)

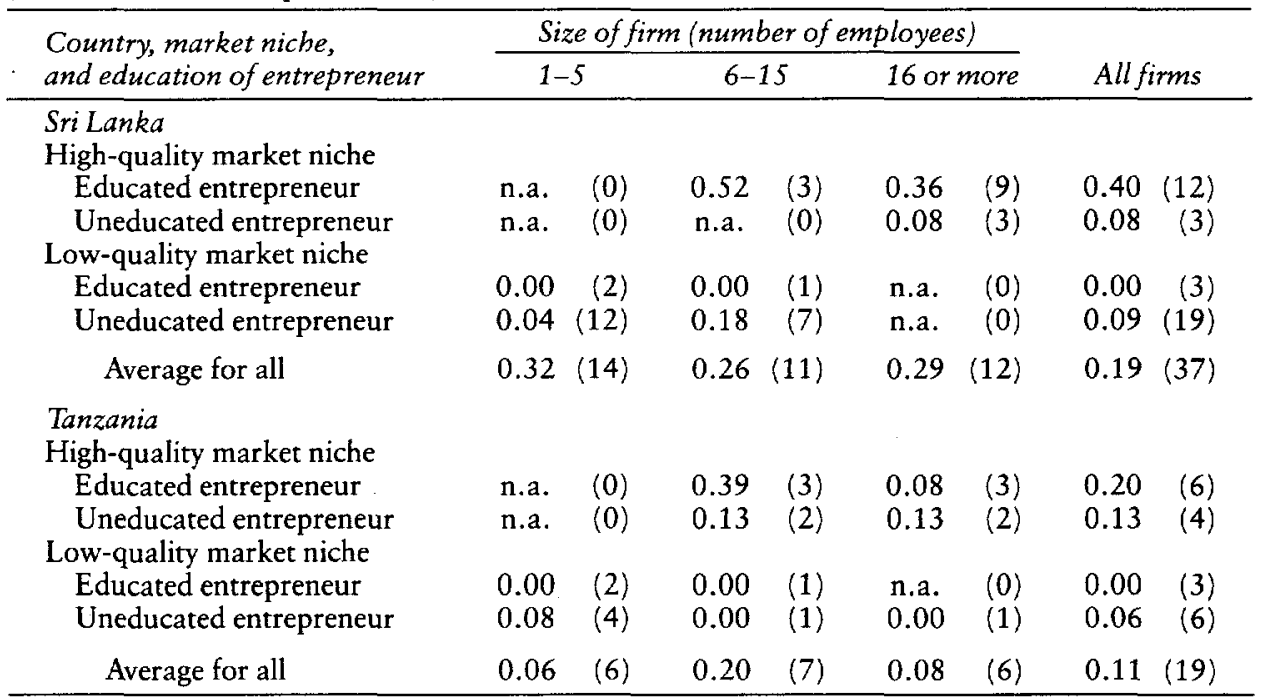

n.a. Not applicable.

Note: Survey respondents' scores were normalized along a scale of 0 to 1 , in which constraints ranked close to 0 are least severe and those ranked close to 1 are most severe. Figures are averages for all firms surveyed. The number of firms interviewed was 38 for Sri Lanka and 20 for Tanzania, but one firm in each country did not provide usable responses to the relevant questions.

Furthermore, market- and entrepreneur-driven influences each appear to have some independent effect: the perception of technical constraint among the SMEs that serve high-quality niches is greater for the educated entrepreneur than for the uneducated one. Correspondingly, among the SMEs with educated entrepreneurs, the perception of technical constraint is greater among those that serve high-quality rather than low-quality market niches.

\section{Reform of Technical and Marketing Constraints}

Interviews revealed that technical and marketing support systems-market and institutional networks (both private and public) external to the firm-were weak in both Sri Lanka and Tanzania. But how to strengthen these support systems remains unresolved. One possibility is that support systems are endogenous-that the weakness of these systems in Sri Lanka and Tanzania is a reflection rather than a cause of the rather simple market niches in which SMES are active, and that as sMEs respond to new opportunities created by policy reform, the private provision of technical and marketing support will increase spontaneously. Alternatively, the weakness of support systems may signal some underlying market failure, which can be overcome only through government intervention. The putative market failure could plausibly be traced to the publicgood character of technical and marketing information and its consequent 
undersupply by private providers. Alternatively, the market failure could be traced to coordination problems that undermine the incentive to be the first entrant in circumstances in which participation on one side of a market creates positive externalities for participants on the other side; here the appropriate role for government is as a catalyst that provides the initial stimulus. Careful empirical analysis of successful experiences of SME and support system development can reveal which of these competing alternatives is closer to the truth.

\section{SME Constraints and the Sequencing of Reforms}

As the empirical analysis has shown, SMEs operate in a complex environment and confront a diverse array of constraints; it is chimerical to search for a single constraint, common across countries, that, once released, will lead to rapid development of sMEs. Not only is there substantial variation among countries as to which constraint is binding, but the release of one constraint is likely to bring to the forefront some other constraint whose inhibiting influence had not previously been evident. Yet for all of this complexity, the analysis has outlined an approach to learning how SMES perceive the impact of the various nonprice constraints and to evaluating the results in relation to other empirical indicators.

The applications of the approach uncovered quite different patterns of SME constraints in Tanzania and Sri Lanka and, within Sri Lanka, between relatively large and small SMEs. The evidence seems unambiguous that lack of access to finance represents the binding constraint on expansion for all classes of sMEs in Tanzania, as well as for smaller, less established firms in Sri Lanka. Furthermore, this constraint appears more severe for the smallest Tanzanian SMEs than for their Sri Lankan counterparts: although formal banks do not lend to the smallest firms in either country, both informal finance and trade credits appear to be more readily available in Sri Lanka. In Tanzania, the financing constraint was followed-again for all SMEs, but with a disproportionately severe impact on the smallest-by the burdens of pervasive and nontransparent tax and regulatory obligations. By contrast, the smallest and least established Sri Lankan enterprises remained informal and reported no difficulties with regulatory authorities. Neither the smallest Sri Lankan nor any of the Tanzanian firms reported technical, marketing, or input constraints to be significant obstacles to expansion, although this appears to reflect more their narrow market and limited information than any underlying capabilities.

Which constraints are most binding is less clear for the larger, established SMEs in Sri Lanka. Although the financing constraint appears to ease as firms grow, a host of new obstacles-no one of which appears to be dominant-come to the fore. Larger Sri Lankan SMEs felt constrained by the limited availability of inputs, vulnerable to heightened scrutiny by tax and other government authorities, limited by weaknesses in their technical skills, and-for the subsample of enterprises that sought to export-frustrated by cumbersome bureaucratic procedures and weak linkages to the international marketplace. 
Learning which constraints bind enterprises is only a first step in setting priorities for reform to promote efficient SME development. Some constraints may not be susceptible to reform. For others, the costs of effective reform may be too high to justify the resultant benefits. Finally, the absence of constraint may signal some undesirable weaknesses in, say, the regulatory environment. Even so, analysis of the kind described in this paper helps to ensure that SME reforms are not driven by preconceived views as to the obstacles to an indigenous supply response, but that the reforms target the constraints that are most binding in practice.

\section{REFERENCES}

The word "processed" describes informally reproduced works that may not be commonly available through library systems.

Biggs, Tyler. 1988. "Financing the Emergence of smes in Taiwan: Heterogenous Firm Size and Efficient Intermediation." EEPA Discussion Paper Number 16. Harvard University, Harvard Institute for International Development, Cambridge, Mass. Processed.

Levy, Brian. 1991a. "Transactions Costs, the Size of Firms, and Industrial Policy." Journal of Development Economics 34: 151-78.

. 1991b. "Strategic Orientations of Firms and the Performance of Korea and Taiwan in Frontier Industries." World Development 19: 4.

Liedholm, Carl. 1990. "The Dynamics of Small-Scale Industry in Africa and the Role of Policy." Gemini Technical Report 2. Washington, D.C.

Liedholm, Carl, and Donald Mead. 1987. "Small-Scale Industries in Developing Countries: Empirical Evidence and Policy Implications." International Development Paper Number 9. Michigan State University, East Lansing. Processed.

Little, I. M. D., Dipak Mazumdar, and John M. Page, Jr. 1987. Small Manufacturing Enterprises. New York: Oxford University Press.

Schmitz, Hubert. 1982. "Growth Constraints on Small-Scale Manufacturing in Developing Countries: A Critical Review." World Development 10: 429-50.

Steel, William, and Leila Webster. 1990. "Ghana's Small Enterprise Sector: Survey of Adjustment Response and Constraints." Industry Series Paper Number 41. World Bank, Industry and Energy Department, Washington, D.C. Processed.

Stone, Andrew, Brian Levy, and Ricardo Paredes. 1991. "Public Institutions and Private Transactions: The Legal and Regulatory Environment for Business Transactions in Brazil and Chile." Policy Research Working Paper 891. World Bank, Country Economics Department, Washington, D.C. Processed.

Webster, Leila. 1991. World Bank Lending for SMEs: Fifteen Years of Experience. World Bank Discussion Paper 113. Washington, D.C. 



\title{
Estimating Returns to Scale with Large, Imperfect Panels: An Application to Chilean Manufacturing Industries
}

\author{
M. Daniel Westbrook and James R. Tybout
}

\begin{abstract}
This study exploits plant-level panel data from Chile to provide new evidence on the empirical significance of scale economies in manufacturing sectors. Particular emphasis is given to econometric problems induced by the presence of unobservable plant heterogeneity, measurement error, and selectivity. An analysis of the results suggests that estimates based on generalized method of moments (GMM) estimators that pool long differences (which eliminate heterogeneity effects) are robust to measurement error in the capital stock, heteroscedasticity, and selectivity. Returns to scale for three-digit industries are fairly evenly distributed over the plausible range of 0.8 to 1.2 , and none is statistically significantly different from constant returns. Similar results bold for the four-digit industries for which sufficient data are available. Although general expansion of the manufacturing sector cannot be expected to yield strong plant-level scale economies, our results do not rule out scale economies from other sources, such as the spreading of start-up costs and external returns to scale. Finally, the analysis has generated several findings of methodological interest, including the notion that Stigler's survival test may indeed be useful as a quick first pass on the empirical importance of returns to scale.
\end{abstract}

Domestic markets for industrial products are often small in developing countries. Accordingly, scale economies in manufacturing sectors can critically influence market structures, growth prospects, and trading patterns. Although the potential importance of these effects has long been recognized by students of development, there has been very little convincing research on their empirical significance. Berry (1992) and Bhagwati (1988) share the concern of Rodrik (1988), who notes that "there is practically no direct evidence on the importance of scale economies in specific industrial sectors of the developing countries." In

M. Daniel Westbrook and James R. Tybout are in the Department of Economics at Georgetown University. This article was prepared for the World Bank research project "Industrial Competition, Productive Efficiency, and Their Relation to Trade Regimes" RPO 674-46. The authors are grateful to John Cuddington, Zvi Griliches, three anonymous referees, and participants in workshops at the National Bureau of Economic Research and at Georgetown for their comments.

(C) 1993 The International Bank for Reconstruction and Development / THE WORLD BANK 
this study we exploit plant-level panel data from Chile to provide direct evidence on the empirical significance of scale economies in manufacturing sectors.

The existing empirical literature is limited, partly because in developing countries data are scarce. More important, the methodologies that have been used to document returns to scale in various countries are subject to a variety of problems. There are at least four approaches in the literature. The first amounts to asking managers what plant size would achieve maximum efficiency. The problem with this methodology is that although managers have some sense of the profitability of plants at alternative sizes, managers are likely to have trouble isolating the effects of technology from other factors. For example, when market power is exercised by large firms, managers may confuse their relative profitability with scale efficiency. Also, big plants may have lower unit costs, because plants with superior management or market niches tend to grow large, whereas others shrivel and die. Demsetz (1973) argued that this evolutionary process explains the correlation between size and profitability typically found in industrial countries. Jovanovic (1982) has formalized the argument in a dynamic learning model in which firms discover their efficiencies through market experience and eventually expand or exit. Related arguments linking productivity and factor demands have appeared many times in the econometric literature, beginning with Marschak and Andrews (1944). Hereafter this phenomenon will be referred to as the Demsetz effect.

The second approach is to commission engineering studies of plant efficiency as a function of size. Although this approach yields the most detailed information, Berry (1992) notes that it is very costly and may itself be subject to certain biases. For example, engineering studies typically hold technology fixed while varying output levels. Thus, alternative technologies that are efficient at small scale tend to be ignored, with the result that returns to scale are overstated. Also, engineering studies tend to ignore nonproduction costs (such as management and distribution) that may rise more than proportionately with plant size.

Stigler (1958) advocated a third approach. He argued that industries exhibiting a wide range of plant sizes in perpetuity must have average cost curves that are flat in the long run. Unfortunately, this logic only works for competitive industries in long-run equilibrium. Barriers to entry and product differentiation permit equilibria along downward-sloping cost functions. And as Jovanovic (1982) and Jovanovic and Lach (1989) have shown, plants of varying efficiencies can coexist indefinitely if they are learning about the market and their own technologies. When product market imperfections are combined with uncertainty in a dynamic context, the scope for cost heterogeneity is further expanded (Pakes and McGuire 1992).

The fourth approach is to use econometric techniques to estimate cost functions or production functions that allow the investigator to infer the relation between size and efficiency. One problem with this approach is that some important variables are not routinely available from industrial surveys-for example, product line descriptions and lengths of production runs. These unobserved factors can confound attempts to infer returns to scale from gross input and 
output flows. Further difficulties arise if Stigler's survivor effect is operative, preventing plants subject to increasing returns from operating. ${ }^{1}$ Similarly, among industries characterized by dominant-fringe market structures, the sheer number of fringe firms may render the influence of major producers negligible in standard estimators. Finally, econometric studies based on cross-sectional variation are likely unable to discriminate between Demsetz effects and scale effects, therefore suffering from significant measurement error bias. Measurement error may be especially acute for capital stocks and factor prices. For the Chilean case, Meller (1975), Corbo and Meller (1979), and Tybout, de Melo, and Corbo (1991) provide examples of cross-sectional econometric analyses of returns to scale based on industrial census data. ${ }^{2}$

Despite the potential drawbacks of the econometric approach, several considerations lead us to use it in this study. We have access to a large panel data set that allows us to deal with Demsetz effects and measurement errors. As will be seen, both of these phenomena turn out to be significant. Because the panel covers virtually all plants with more than ten workers, it provides a much broader basis for generalization than do detailed studies of specific product lines. And, unlike engineering studies and attitudinal surveys, panel-based econometric estimates infer returns to scale from the observed temporal variation in inputs and outputs. Hence they come closer to describing the realized scale effects that accompanied demand shifts and policy changes during the sample period.

Section I presents our assumptions regarding technology and behavior. Section II discusses alternative estimators that deal with different aspects of the econometric problems we face. Applications of the alternative estimators to various three-digit and four-digit industries are reported in section III, and an attempt is made to determine which estimates of returns to scale are the most reliable.

\section{TECHNOLOGY AND BEHAVIOR}

The relationship between input and output flows in manufacturing is determined by the technology employed and by the economic behavior of the producers. Our assumptions regarding these aspects of production are detailed in the following subsections.

\section{Technology}

We begin with a simple Cobb-Douglas representation of technology for a particular industry:

$$
Y_{i t}=\alpha L_{i t}+\beta K_{i t}^{\ddot{t}}+\epsilon_{i t}
$$

1. More subtle selectivity problems can bias studies based on panel data, as will be seen later.

2. The Tybout, de Melo, and Corbo (1991) study addresses the problem of measurement error, but is still subject to the other biases mentioned in this paragraph. 
Here $i$ is the firm subscript, $t$ is the time period subscript, and the industry subscript is suppressed. The logarithm of real value added is denoted by $Y$, the logarithm of labor (measured in efficiency units) by $L$, the logarithm of the true capital stock by $K^{*}$, and an error term by $\epsilon_{i t}$.

Although this functional form is restrictive, the coefficients can be indexed by the size range of firms being examined, thus providing a basis for testing whether measured returns to scale depend on plant size (Meller 1975; Griliches and Ringstad 1971). Experiments along these lines revealed no clear tendency for returns to scale to rise or fall with plant size, so we do not pursue the matter further here. ${ }^{3}$

The error term is assumed to have three components that are unobservable to the econometrician:

$$
\epsilon_{i t}=\mu_{i}+\tau_{t}+\xi_{i t}
$$

The first component, $\mu_{i}$, is a plant-specific effect that reflects heterogeneous technologies and management skills. The second component, $\tau_{t}$, is a time effect that is common to all plants. It reflects returns to scale at the industry level, general changes in capacity utilization, and technological innovation. Both $\mu_{i}$ and $\tau_{t}$ may be correlated with the exogenous variables. Remaining noise is reflected in $\xi_{i t}$, which is assumed to be identically independently distributed across plants and time and uncorrelated with the exogenous variables.

\section{Behavior}

To characterize producer behavior, we adopt the perspective of Olley and Pakes (1992) and Ericson and Pakes (1987). To simplify the estimation problem, our specification is more restrictive than the specifications of these authors, in that $\mu_{i}$ is not allowed to vary over time. Given current capital stocks, managers are presumed to maximize expected future profits by deciding whether to operate in the coming period and, if so, by choosing appropriate levels of employment and investment. This means that factor stocks in the current period, as well as in the last period, are functions of expectations about future productivity and market conditions. Thus, because expected productivity and market conditions are functions of $\mu_{i}$ and $\tau_{t}$, and because managers are likely to have information on both of these error components, investment and employment levels are generally correlated with the composite disturbance $\epsilon_{i t}$.

More precisely, under reasonable assumptions, the cross-sectional correlation between plants' productivities and their capital stocks is positive. Thus, ordinary least squares (OLS) estimates of equation 1 tend to overstate returns to scale. Using dynamic optimization-with-uncertainty models, Ericson and Pakes (1987), Pakes and McGuire (1992), Jovanovic (1982), and Benhabib and Jov-

3. The results of this exercise are available from the authors upon request. For a related study of Mexican manufacturing plants, see Tybout and Westbrook (1992). 
anovic (1991) formally demonstrate that productivity and factor demands will be positively correlated. This is the Demsetz effect, and any consistent estimator of production technology must control for its presence. Factor demands are uncorrelated with $\xi_{i t}$ so long as its realizations are unanticipated by managers.

\section{ESTIMATORS}

Estimation of equation 1 is complicated by the presence of the plant-specific and time-period-specific components of the disturbance term, and by measurement error and a selection process generated by the entry and exit behavior of plants. Econometric approaches designed to mitigate the effects of these problems are discussed in this section.

\section{Plant and Time Effects}

The bias that results from the Demsetz effect can be eliminated if the error components $\mu_{i}$ and $\tau_{t}$ can be removed from the production function disturbance. Two standard ways of doing so-within estimation and difference estimationare reviewed below. In that discussion it is convenient to assume that all explanatory variables are measured without error. This assumption is relaxed in the subsection on measurement error.

The within estimator. Perhaps the most common way to sweep out the plant effects, $\mu_{i}$, is known as within estimation. This name reflects the fact that only temporal, or within-plant, variation in the data is exploited. It amounts to including plant-specific dummy variables in the regression or, equivalently, to performing ous on variables expressed in terms of deviations from their plantspecific means. That is, any variable $x_{i t}$ appearing in the regression is replaced with $\tilde{x}_{i t}$ :

$$
\tilde{x}_{i t}=x_{i t}-\left(\frac{1}{T}\right) \sum_{t=1}^{T} x_{i t}, \quad i=1, \ldots, N
$$

The time effects common to all plants $\left(\tau_{t}\right)$ may also be swept out by including time dummies in the model or by further transforming all variables $\tilde{x}_{i t}$ to deviations from their year-specific means. Elimination of time effects also serves to control for sectorwide measurement errors in output growth that are the result of, for example, inappropriate price deflators.

The difference estimators. An alternative way to sweep out plant effects is to difference the data. The $j$ th difference estimator amounts to performing ols on variables transformed as

$$
d x_{i t}=x_{i t}-x_{i t-j}
$$

where $d^{j}$ denotes the $j$ th-difference operator. If there are $T$ time periods in the panel, any $j$ value between 1 and $T-1$ inclusive may be chosen.

Like the within estimator, this technique permits consistent estimation of the 
structural coefficients when plant effects are correlated with included explanatory variables. Time dummies can be used to control for variation through time that is common to all plants. However, unlike the within transformation, the difference transformation yields transformed disturbances that involve only $\xi_{i t}$ and $\xi_{i t-j}$, rather than a weighted average of disturbances in all years. This feature of difference estimators affords more flexibility than the within estimator when treating measurement error or endogeneity problems. Long-difference (large $j$ ) estimators also tend to be less sensitive to measurement error than within estimators (Griliches and Hausman 1986). For both of these reasons, we base most of the remaining analysis on difference estimators.

There are several disadvantages to working with difference estimators. Because difference estimators identify parameters exclusively with temporal variation in the data, estimated coefficients reflect the marginal productivities of the factors. This means that estimates of returns to scale may be too small if timeinvariant start-up costs are important. When factor stocks are imperfectly measured, difference estimators may be more sensitive to measurement error bias than are estimators that exploit cross-sectional variation in the data. And because difference estimators require data from periods $t-j$ and $t$, plants not present in both periods are excluded from the analysis. This creates the potential for selectivity bias.

There is no obvious way to incorporate start-up costs in returns to scale estimators based on differenced data, so our estimates of returns to scale are exclusive of their influence. But there are ways of dealing with measurement error and selectivity bias; we take these up in the following subsections.

\section{Measurement Error}

Accounting measures of capital stocks are based on historic purchase costs and smooth depreciation rates. Even if some adjustment is made for inflation, these measures generally do a poor job of describing the true flow of capital services. Hence, as detailed below, it is likely that all of the estimators discussed above are asymptotically biased.

Suppose that the capital stock observable to the econometrician $\left(K_{i t}\right)$ may be written as the true stock $\left(K_{i t}^{*}\right)$, plus noise $\left(\nu_{i t}\right)$ :

$$
K_{i t}=K_{i t}^{*}+\nu_{i t}
$$

where $\nu_{i t}$ is uncorrelated with $\mu_{i}, \tau_{t}$, and $\xi_{i t}$. Then the $j$ th-difference estimator $\left(a_{j}\right.$, $b_{j}$ ) for the coefficients on labor and capital stock $(\alpha, \beta)$ amounts to performing OLS on

$$
d^{j} Y_{i t}=\alpha\left(d^{j} L_{i t}\right)+\beta\left(d i K_{i t}\right)+d\left(\epsilon_{i t}-\beta \nu_{i t}\right) .
$$

Correlation between $d i K_{i t}$ and the transformed disturbance term $\left(d i\left[\epsilon_{i t}-\beta \nu_{i t}\right]\right)$ induces the usual measurement error bias.

In the appendix we extend Griliches and Hausman (1986) and derive the asymptotic bias of the $j$ th-difference estimator of returns to scale $(\alpha+\beta)$. The 
asymptotic bias can be characterized in terms of the variances and serial correlations of the measurement error and observed capital stock, the population regression coefficient when $d i L$ is regressed on $d K$ and time dummies, and the length of the difference, $j$. Under plausible conditions, the bias is negative and declines with longer differences.

To obtain estimates that are (asymptotically) free of measurement error bias and to exploit all the information in the sample, we follow Griliches and Hausman (1986) and use a generalized method of moments (GMM) estimator. This approach is discussed in White (1982), Holtz-Eakin and others (1988), and Arellano and Bond (1988). It amounts to instrumenting the various difference equations and pooling the corresponding orthogonality conditions. An added advantage of this approach is that it corrects for heteroscedasticity.

In our application, we need instruments that are correlated with changes in true capital stocks but uncorrelated with measurement error. We settle on three variables for each difference equation. The first instrumental variable is the change in employment level between the initial and final periods of the difference. As long as managers do not anticipate $\xi_{i t}$ when choosing employment levels, employment is orthogonal to the structural disturbance in the current period. The second instrumental variable is the change in net purchases of machinery and equipment between the initial and final periods of the difference. If the measurement error in capital stocks comes from longer-term items (land and buildings), machinery and equipment will be correlated with growth in the flow of capital services, but uncorrelated with the measurement error $\boldsymbol{v}_{i t}$ (Tybout 1992). The third instrumental variable is the change in real wages between the initial and final periods. Unless real wages are completely unpredictable, they will be correlated with expected profits, and they should thus be correlated with true capital stocks.

As shown in the appendix, elimination of measurement error bias should reduce the estimated coefficient on labor, increase the estimated coefficient on capital, and increase the estimated returns to scale. Because the justification for each instrumental variable may be subject to criticism, we compared the results with those from uninstrumented difference estimators to check whether the coefficients moved in the expected direction. The results are discussed in section III.

\section{Selectivity Bias}

It is well known that young plants tend to be small and to have relatively high failure rates. It is also true that among these plants, the least efficient ones fail more frequently. ${ }^{4}$ If plants that are not observed in all sample years are left out

4. For evidence that this is the case in our Chilean panel, see Liu (1991). Entry and exit in the Chilean data amount to appearance or disappearance from the annual survey of manufacturers. Because this survey comprehensively covers plants with more than ten workers and excludes the rest, entry and exit may amount to crossing the ten-worker threshold rather than birth or death. 
of the analysis altogether, the estimated change in input per unit of change in output may be biased. For example, if the less efficient plants require relatively large increments to inputs per unit of change in output, their omission would likely lead to estimates of returns to scale that are too high. Conversely, if the inefficient plants are those that are in the range of increasing returns, then selectivity bias may cause estimates of returns to scale to be too low (Olley and Pakes 1992).

To examine the nature and importance of selectivity bias, we proceed in two stages. First, we apply the estimators introduced above to the subset of plants that are observed for the entire sample period. We call this the balanced subsample. It is useful as a reference case because most studies of returns to scale deal only with such data sets. We then add plants that are missing for some portion of the sample period, but that can be observed for some of the difference equations. This addition brings in plants that enter the sample and stay in for at least a year, as well as plants that exit after the terminal year of the $j$ th-difference equation.

Second, we make a selectivity correction for plants that are observed in the initial year of a difference equation but not in the final year. This corrects for the bias induced by systematically underrepresenting failing plants in the sample. The selectivity correction is made using a Heckman (1979) two-stage procedure, which amounts to estimating a probit model that forecasts whether a plant existing in year $t-j$ is still existing in year $t$. The concomitant parameter estimates are used to construct a Mills ratio that is added to the set of explanatory variables in the $j$ th-difference equation.

\section{Applying the Estimators to Chilean Data}

In this section, we apply the various estimators to Chilean panel data. We compare ols and within estimators for evidence on the combined importance of the problems. We compare long- and short-difference estimators (among others) to help isolate the role of measurement error. And we compare the results of balanced panels with those based on extended samples, with and without Mills ratio corrections, to shed light on the importance of selectivity bias. We then report and draw inferences from GMM estimates of returns to scale that are robust with respect to measurement error and selectivity bias.

The data we use cover virtually all Chilean manufacturing firms with at least ten workers and that were observed at least twice during the period 1979-86. ${ }^{5}$ Outputs are deflated by using sector-specific output price deflators. Intermediate goods are deflated by using price indexes constructed from sectoral output prices in the 1977 Chilean input-output table. Energy usage is measured by using a

5. The data were supplied to the World Bank by the Chilean government in connection with the research project "Industrial Competition, Productive Efficiency, and Their Relation to Trade Regimes" (RPO-674-46). 
plant-level Laspeyres quantity index based on physical volumes and values reported for each fuel type. Capital stocks are imputed by applying the perpetual inventory method to deflated investment figures for each of four categories of capital goods. Base-year capital stocks are taken from 1980 financial statements. These statements should roughly reflect replacement costs, because in 1979 firms were instructed to revalue their capital stocks according to market worth (the retacación técnica). A more detailed description of the data may be found in Liu (1990).

\section{Evidence on Specification Problems}

As discussed earlier, so long as efficient plants grow more rapidly and fail less frequently than inefficient plants, ols is likely to overstate returns to scale. This bias can be eliminated by sweeping plant-specific efficiency effects out of the disturbance term with either a within or a difference estimator. However, in doing so, we miss returns to scale that are a result of sunk start-up costs, and we probably exacerbate measurement error bias. Both of these unwanted side effects should push the estimated returns to scale downward. Thus, ignoring selectivity effects for the moment, there are three reasons why within estimates might lie below ols estimates. To gauge whether the Demsetz effect, measurement error, or sunk costs are empirically worth worrying about, we compare oLs and within estimates for the 16 three-digit industries in table 1 . A quick review of the findings suggests that there is cause for concern: the oLs estimates of returns to scale are above the within estimates in all industries. Which explanation or explanations account for the discrepancy remain to be seen.

Capital stock measurement error. Lacking instruments that are correlated with sunk costs but orthogonal to productivity, we cannot test for the significance of start-up costs. But the nature of the measurement error problem can be pursued further. Specifically, if correlation between plant effects and factor stocks were the only problem with oLs estimators, the within estimator would be consistent. However, the within estimates of returns to scale reported in table 1 are too low to be plausible. Furthermore, the relative magnitudes of our various difference estimators suggest that measurement error in capital stocks is part of the explanation.

The appendix shows that when three conditions are satisfied, measurement error biases the estimates of returns to scale downward by an amount that declines with the length of the difference estimator used. The first condition is that the serial correlation in the measurement errors, $\operatorname{corr}\left(\nu_{i t}, \nu_{i t-j}\right)$, reaches a lower bound beyond some $j$. The second is that the variances in differenced capital stocks grow monotonically with the difference length. And the third is that the auxiliary regression of labor on capital yields a coefficient of value less than one $(\gamma<1)$. Although the first condition cannot be directly addressed, table A-1, in the appendix, provides evidence in support of the other two.

Table 2 shows that, as predicted, short-difference estimators typically yield 
Table 1. oLs and Within-Plant Estimators of Cobb-Douglas Technology for Chilean Manufacturing Industries, 1979-86

\begin{tabular}{|c|c|c|c|c|c|c|c|c|}
\hline \multirow[b]{4}{*}{ Sector name and number } & \multicolumn{8}{|c|}{ Estimation procedure } \\
\hline & \multicolumn{4}{|c|}{ Ordinary least squares } & \multicolumn{4}{|c|}{ Within-plant } \\
\hline & \multirow{2}{*}{$\begin{array}{l}\text { Degrees } \\
\text { of } \\
\text { freedom }\end{array}$} & \multicolumn{2}{|c|}{ Coefficient } & \multirow{2}{*}{$\begin{array}{c}\text { Estimate } \\
\text { of returns } \\
\text { to scale }\end{array}$} & \multirow{2}{*}{$\begin{array}{l}\text { Degrees } \\
\text { of } \\
\text { freedom }\end{array}$} & \multicolumn{2}{|c|}{ Coefficient } & \multirow{2}{*}{$\begin{array}{c}\text { Estimate } \\
\text { of returns } \\
\text { to scale }\end{array}$} \\
\hline & & $\begin{array}{c}\text { On } \\
\text { labor }\end{array}$ & $\begin{array}{c}\text { On } \\
\text { capital }\end{array}$ & & & $\begin{array}{l}\text { On } \\
\text { labor }\end{array}$ & $\begin{array}{c}\text { On } \\
\text { capital }\end{array}$ & \\
\hline Food, 312 & 5,366 & $\begin{array}{c}0.7937 \\
(45.55)\end{array}$ & $\begin{array}{c}0.3961 \\
(37.05)\end{array}$ & $\begin{array}{c}1.1898 \\
(0.0118)\end{array}$ & 4,694 & $\begin{array}{c}0.5303 \\
(19.98)\end{array}$ & $\begin{array}{c}0.1399 \\
(5.22)\end{array}$ & $\begin{array}{c}0.6702 \\
(0.0349)\end{array}$ \\
\hline Beverages, 313 & 333 & $\begin{array}{c}1.1164 \\
(17.20)\end{array}$ & $\begin{array}{c}0.2296 \\
(5.69)\end{array}$ & $\begin{array}{c}1.3460 \\
(0.0464)\end{array}$ & 290 & $\begin{array}{l}0.6023 \\
(5.68)\end{array}$ & $\begin{array}{c}0.0564 \\
(0.50)\end{array}$ & $\begin{array}{c}0.6587 \\
(0.1512)\end{array}$ \\
\hline Textiles, 321 & 1,254 & $\begin{array}{c}0.7178 \\
(24.64)\end{array}$ & $\begin{array}{c}0.2686 \\
(12.37)\end{array}$ & $\begin{array}{c}0.9864 \\
(0.0168)\end{array}$ & 1,096 & $\begin{array}{c}0.4384 \\
(8.40)\end{array}$ & $\begin{array}{c}0.2301 \\
(4.49)\end{array}$ & $\begin{array}{c}0.6685 \\
(0.0670)\end{array}$ \\
\hline Apparel, 322 & 1,054 & $\begin{array}{l}0.9957 \\
(32.28)\end{array}$ & $\begin{array}{l}0.1254 \\
\langle 5.07)\end{array}$ & $\begin{array}{c}1.1211 \\
(0.0233)\end{array}$ & 921 & $\begin{array}{c}0.5942 \\
(10.30)\end{array}$ & $\begin{array}{l}0.1502 \\
(2.76)\end{array}$ & $\begin{array}{c}0.7444 \\
(0.0712)\end{array}$ \\
\hline Footwear, 324 & 454 & $\begin{array}{l}0.9615 \\
(18.19)\end{array}$ & $\begin{array}{l}0.1770 \\
(5.21)\end{array}$ & $\begin{array}{c}1.1385 \\
(0.0291)\end{array}$ & 396 & $\begin{array}{l}0.6019 \\
(6.65)\end{array}$ & $\begin{array}{l}0.2274 \\
(2.67)\end{array}$ & $\begin{array}{c}0.8293 \\
(0.1091)\end{array}$ \\
\hline Wood products, 331 & 846 & $\begin{array}{c}0.7865 \\
(16.65)\end{array}$ & $\begin{array}{l}0.2731 \\
(8.33)\end{array}$ & $\begin{array}{c}1.0626 \\
(0.0325)\end{array}$ & 739 & $\begin{array}{c}0.5330 \\
(6.18)\end{array}$ & $\begin{array}{l}0.2700 \\
(2.64)\end{array}$ & $\begin{array}{c}0.8030 \\
(0.1205)\end{array}$ \\
\hline Furniture, 332 & 310 & $\begin{array}{c}0.8746 \\
(12.01)\end{array}$ & $\begin{array}{l}0.3956 \\
(8.49)\end{array}$ & $\begin{array}{c}1.2702 \\
(0.0448)\end{array}$ & 260 & $\begin{array}{l}0.6002 \\
(4.79)\end{array}$ & $\begin{array}{l}0.1873 \\
(1.81)\end{array}$ & $\begin{array}{c}0.7875 \\
(0.1512)\end{array}$ \\
\hline Printing, 342 & 619 & $\begin{array}{l}0.6874 \\
(20.03)\end{array}$ & $\begin{array}{l}0.3331 \\
(12.86)\end{array}$ & $\begin{array}{c}1.0205 \\
(0.0206)\end{array}$ & 540 & $\begin{array}{l}0.3640 \\
(6.40)\end{array}$ & $\begin{array}{l}0.2202 \\
(3.00)\end{array}$ & $\begin{array}{c}0.5842 \\
(0.0807)\end{array}$ \\
\hline Miscellaneous chemicals, 352 & 590 & $\begin{array}{l}0.7043 \\
(15.51)\end{array}$ & $\begin{array}{l}0.4007 \\
(12.28)\end{array}$ & $\begin{array}{c}1.1049 \\
(0.0285)\end{array}$ & 515 & $\begin{array}{l}0.2521 \\
(4.62)\end{array}$ & $\begin{array}{l}0.1674 \\
(2.71)\end{array}$ & $\begin{array}{c}0.4195 \\
(0.0750)\end{array}$ \\
\hline Rubber products, 355 & 230 & $\begin{array}{c}0.7097 \\
(12.09)\end{array}$ & $\begin{array}{l}0.3699 \\
(7.62)\end{array}$ & $\begin{array}{c}1.0796 \\
(0.0388)\end{array}$ & 200 & $\begin{array}{l}0.3076 \\
(3.30)\end{array}$ & $\begin{array}{l}0.3413 \\
(3.04)\end{array}$ & $\begin{array}{c}0.6489 \\
(0.1286)\end{array}$ \\
\hline Plastics, 356 & 366 & $\begin{array}{c}0.6069 \\
(9.42)\end{array}$ & $\begin{array}{l}0.2651 \\
(6.15)\end{array}$ & $\begin{array}{c}0.8720 \\
(0.0443)\end{array}$ & 319 & $\begin{array}{c}0.3351 \\
(2.53)\end{array}$ & $\begin{array}{l}0.5210 \\
(4.59)\end{array}$ & $\begin{array}{c}0.8651 \\
(0.1459)\end{array}$ \\
\hline Nonmetallic mineral products, 369 & 302 & $\begin{array}{c}0.7549 \\
\langle 11.95\rangle\end{array}$ & $\begin{array}{l}0.3129 \\
(9.68)\end{array}$ & $\begin{array}{c}1.0678 \\
(0.0394)\end{array}$ & 263 & $\begin{array}{l}0.5090 \\
(5.46)\end{array}$ & $\begin{array}{l}0.1111 \\
(1.42)\end{array}$ & $\begin{array}{c}0.6201 \\
(0.1139)\end{array}$ \\
\hline Metal products, 381 & 1,110 & $\begin{array}{l}0.9404 \\
(29.31)\end{array}$ & $\begin{array}{l}0.2272 \\
(10.27)\end{array}$ & $\begin{array}{l}1.1676 \\
(0.0219)\end{array}$ & 970 & $\begin{array}{l}0.4515 \\
(7.99)\end{array}$ & $\begin{array}{l}0.1472 \\
(3.00)\end{array}$ & $\begin{array}{c}0.5987 \\
(0.0693)\end{array}$ \\
\hline Nonelectric machinery, 382 & 261 & $\begin{array}{c}0.7406 \\
(12.60)\end{array}$ & $\begin{array}{l}0.3437 \\
(8.65)\end{array}$ & $\begin{array}{c}1.0843 \\
(0.0454)\end{array}$ & 327 & $\begin{array}{c}0.2831 \\
(3.42)\end{array}$ & $\begin{array}{l}0.0709 \\
(0.85)\end{array}$ & $\begin{array}{c}0.3540 \\
(0.1011)\end{array}$ \\
\hline Electric machinery, 383 & 182 & $\begin{array}{c}0.6470 \\
(8.76)\end{array}$ & $\begin{array}{l}0.4011 \\
(7.17)\end{array}$ & $\begin{array}{c}1.0481 \\
(0.0427)\end{array}$ & 158 & $\begin{array}{c}0.4778 \\
(4.49)\end{array}$ & $\begin{array}{l}0.2746 \\
(1.86)\end{array}$ & $\begin{array}{c}0.7524 \\
(0.1719)\end{array}$ \\
\hline Transportation equipment, 384 & 230 & $\begin{array}{c}0.8780 \\
(10.66)\end{array}$ & $\begin{array}{l}0.2341 \\
(3.90)\end{array}$ & $\begin{array}{c}1.1121 \\
(0.0462)\end{array}$ & 200 & $\begin{array}{l}0.6989 \\
(5.52)\end{array}$ & $\begin{array}{l}0.2916 \\
(2.05)\end{array}$ & $\begin{array}{c}0.9905 \\
(0.1571)\end{array}$ \\
\hline
\end{tabular}

Note: Estimates are obtained based on equation 1, using balanced-panel data; only plants that appear in all sample years are included, and industries with fewer than 20 such plants are not analyzed. Although not reported, time dummies are included in the regressions. $t$-ratios are in parentheses.

Source: Authors' calculations. 
estimates of returns to scale that are substantially lower than long-difference estimators (the fifth, sixth, and seventh). Although this pattern is not evident for some industries, the average estimates of returns to scale across industries clearly reveal a positive association between difference length and returns to scale. This, too, is consistent with the representation of measurement error in the appendix.

Hausman tests comparing oLs difference estimates and instrumental variables estimates show that the measurement error bias is often significant. The test statistics are constructed in terms of the differences between the oLs and instrumental variables capital coefficients and the corresponding difference between their estimated variances that are consistent with heteroscedasticity. ${ }^{6}$ As expected, the incidence of rejection of the hypothesis of no measurement error bias decreases in moving from fifth to sixth and from sixth to seventh differences. Because the industries are independent samples, a joint test can easily be constructed by summing the Hausman test statistics. In doing so, we reject the null hypothesis of no measurement error. ${ }^{7}$ Although the Hausman tests on labor and capital coefficients jointly generate a few more inadmissible values, the pattern of weaker rejections is maintained. In sum, our findings present a coherent picture of significant measurement error in capital stocks that declines in severity as the length of the difference estimator increases.

Selectivity bias. Selectivity bias also may account for the low within and difference estimates of returns to scale reported in tables 1 and 2. Selectivity bias may occur on two levels. First, if a balanced panel is used (as in tables 1 and 2), plants that do not appear in all sample years are left out of the analysis altogether. Second, even if an extended panel is used, plants that drop out of the sample before the final year of a particular difference equation will be left out of that equation.

To gauge the first bias, we compare simple difference estimates based on balanced data with those based on all available observations for each equation. Table 3 shows the proportional increase in estimated returns to scale based on first- through seventh-difference equations. The change in estimated returns to scale is substantial for a number of industries. This confirms the Olley and Pakes (1992) finding that the omission of entering and exiting plants can lead to significant biases in estimates of technology. It is clear that entering and exiting plants differ from incumbents not only in their mean productivity levels (plant effects), but also in their returns to scale. (For further analysis of the nature of this difference, see Liu 1991.) However, the manner in which plants differ varies across industries. Two patterns appear dominant: moving from the balanced to

6. In three instances for the sixth differences and two for the seventh differences, the difference in variances was negative-a small sample problem. These statistics were set to zero for the joint tests, biasing our decision rule toward acceptance.

7. The $P$-value is $8.555 \mathrm{E}-11$ for the fifth-difference estimators, 0.0011 for the sixth-difference estimators, and 0.0125 for the seventh-difference estimators. 
Table 2. Simple-Difference Estimators of Returns to Scale and the Coefficient on Capital for Chilean Manufacturing Industries, 1979-86

\begin{tabular}{|c|c|c|c|c|c|c|c|}
\hline \multirow{2}{*}{$\begin{array}{l}\text { Sector name and number } \\
\text { and sample statistic }\end{array}$} & \multicolumn{7}{|c|}{ Difference estimator } \\
\hline & $1 s t$ & $2 n d$ & $3 r d$ & $4 t h$ & 5 th & $6 t h$ & 7 th \\
\hline \multicolumn{8}{|l|}{ Food, 312} \\
\hline \multirow{2}{*}{$\begin{array}{l}\text { Estimate of returns to scale } \\
\text { Estimated coefficient on } \\
\text { capital }\end{array}$} & 0.541 & 0.640 & 0.714 & 0.733 & 0.667 & 0.702 & 0.692 \\
\hline & $\begin{array}{c}0.010 \\
(2.36)\end{array}$ & $\begin{array}{c}0.163 \\
(4.31)\end{array}$ & $\begin{array}{c}0.162 \\
(4.71)\end{array}$ & $\begin{array}{c}0.152 \\
(4.67)\end{array}$ & $\begin{array}{r}0.123 \\
(3.65)\end{array}$ & $\begin{array}{r}0.107 \\
(2.94)\end{array}$ & $\begin{array}{r}0.133 \\
(3.03)\end{array}$ \\
\hline \multicolumn{8}{|l|}{ Beverages, 313} \\
\hline \multirow{2}{*}{$\begin{array}{l}\text { Estimate of returns to scale } \\
\text { Estimated coefficient on } \\
\text { capital }\end{array}$} & 0.403 & 0.367 & 0.671 & 0.737 & 0.624 & 0.611 & 1.381 \\
\hline & $\begin{array}{r}0.050 \\
(0.25)\end{array}$ & $\begin{array}{c}0.042 \\
(0.30)\end{array}$ & $\begin{array}{r}0.170 \\
(1.30)\end{array}$ & $\begin{array}{r}0.079 \\
(0.57)\end{array}$ & $\begin{array}{c}0.043 \\
(0.28)\end{array}$ & $\begin{array}{l}-0.192 \\
(-1.25)\end{array}$ & $\begin{array}{c}0.149 \\
(0.90)\end{array}$ \\
\hline \multicolumn{8}{|l|}{ Textiles, 321} \\
\hline \multirow{2}{*}{$\begin{array}{l}\text { Estimate of returns to scale } \\
\text { Estimated coefficient on } \\
\text { capital }\end{array}$} & 0.439 & 0.543 & 0.647 & 0.729 & 0.787 & 0.795 & 0.745 \\
\hline & $\begin{array}{r}0.140 \\
(1.78)\end{array}$ & $\begin{array}{r}0.175 \\
(2.55)\end{array}$ & $\begin{array}{c}0.198 \\
(3.14)\end{array}$ & $\begin{array}{r}0.246 \\
(3.14)\end{array}$ & $\begin{array}{r}0.263 \\
(4.01)\end{array}$ & $\begin{array}{c}0.264 \\
(4.00)\end{array}$ & $\begin{array}{r}0.229 \\
(2.48)\end{array}$ \\
\hline \multicolumn{8}{|l|}{ Apparel, 322} \\
\hline \multirow{2}{*}{$\begin{array}{l}\text { Estimate of returns to scale } \\
\text { Estimated coefficient on } \\
\text { capital }\end{array}$} & 0.387 & 0.543 & 0.651 & 0.824 & 0.972 & 0.919 & 1.077 \\
\hline & $\begin{array}{c}0.124 \\
(1.53)\end{array}$ & $\begin{array}{r}0.078 \\
(1.06)\end{array}$ & $\begin{array}{c}0.122 \\
(1.73)\end{array}$ & $\begin{array}{r}0.109 \\
(1.60)\end{array}$ & $\begin{array}{r}0.189 \\
(2.88)\end{array}$ & $\begin{array}{c}0.174 \\
(2.40)\end{array}$ & $\begin{array}{r}0.135 \\
(1.66)\end{array}$ \\
\hline \multicolumn{8}{|l|}{ Footwear, 324} \\
\hline \multirow{2}{*}{$\begin{array}{l}\text { Estimate of returns to scale } \\
\text { Estimated coefficient on } \\
\text { capital }\end{array}$} & 0.383 & 0.651 & 0.876 & 0.881 & 0.908 & 0.943 & 1.110 \\
\hline & $\begin{array}{r}0.173 \\
(1.30)\end{array}$ & $\begin{array}{c}0.183 \\
(1.62)\end{array}$ & $\begin{array}{c}0.188 \\
(1.80)\end{array}$ & $\begin{array}{r}0.207 \\
(1.98)\end{array}$ & $\begin{array}{r}0.309 \\
(2.85)\end{array}$ & $\begin{array}{c}0.174 \\
(1.45)\end{array}$ & $\begin{array}{c}0.164 \\
(1.10)\end{array}$ \\
\hline \multicolumn{8}{|l|}{ Wood products, 331} \\
\hline \multirow{2}{*}{$\begin{array}{l}\text { Estimate of returns to scale } \\
\text { Estimated coefficient on } \\
\text { capital }\end{array}$} & 0.661 & 0.735 & 0.843 & 0.890 & 0.895 & 0.817 & 0.537 \\
\hline & $\begin{array}{c}0.208 \\
(1.29)\end{array}$ & $\begin{array}{c}0.212 \\
(1.52)\end{array}$ & $\begin{array}{r}0.284 \\
(2.12)\end{array}$ & $\begin{array}{r}0.273 \\
(2.21)\end{array}$ & $\begin{array}{r}0.356 \\
(2.69)\end{array}$ & $\begin{array}{c}0.297 \\
(2.11)\end{array}$ & $\begin{array}{r}0.173 \\
(1.05)\end{array}$ \\
\hline \multicolumn{8}{|l|}{ Furniture, 332} \\
\hline \multirow{2}{*}{$\begin{array}{l}\text { Estimate of returns to scale } \\
\text { Estimated coefficient on } \\
\text { capital }\end{array}$} & 0.631 & 0.618 & 0.756 & 0.827 & 1.008 & 0.892 & 0.756 \\
\hline & $\begin{array}{r}0.233 \\
(1.26)\end{array}$ & $\begin{array}{c}0.160 \\
(1.25)\end{array}$ & $\begin{array}{r}0.103 \\
(0.76)\end{array}$ & $\begin{array}{r}0.220 \\
(1.68)\end{array}$ & $\begin{array}{r}0.157 \\
(1.29)\end{array}$ & $\begin{array}{r}0.227 \\
(1.58)\end{array}$ & $\begin{array}{r}0.195 \\
(1.30\rangle\end{array}$ \\
\hline \multicolumn{8}{|l|}{ Printing, 342} \\
\hline \multirow{2}{*}{$\begin{array}{l}\text { Estimate of returns to scale } \\
\text { Estimated coefficient on } \\
\text { capital }\end{array}$} & 0.386 & 0.562 & 0.645 & 0.547 & 0.574 & 0.621 & 0.773 \\
\hline & $\begin{array}{c}0.122 \\
(1.01)\end{array}$ & $\begin{array}{c}0.170 \\
(1.77)\end{array}$ & $\begin{array}{r}0.223 \\
(2.52)\end{array}$ & $\begin{array}{c}0.301 \\
(3.45)\end{array}$ & $\begin{array}{c}0.234 \\
(2.47)\end{array}$ & $\begin{array}{c}0.202 \\
(1.81)\end{array}$ & $\begin{array}{r}0.185 \\
(1.74)\end{array}$ \\
\hline \multirow{3}{*}{$\begin{array}{l}\text { Miscellaneous chemicals, } 352 \\
\text { Estimate of returns to scale } \\
\text { Estimated coefficient on } \\
\text { capital }\end{array}$} & & & & & & & \\
\hline & 0.074 & 0.320 & 0.374 & 0.487 & 0.548 & 0.626 & 0.407 \\
\hline & $\begin{array}{r}0.033 \\
(0.33)\end{array}$ & $\begin{array}{c}0.142 \\
(1.79)\end{array}$ & $\begin{array}{c}0.146 \\
(1.99)\end{array}$ & $\begin{array}{r}0.139 \\
(1.83)\end{array}$ & $\begin{array}{c}0.158 \\
(1.89)\end{array}$ & $\begin{array}{c}0.248 \\
(2.71)\end{array}$ & $\begin{array}{r}0.201 \\
(1.65)\end{array}$ \\
\hline \multirow{3}{*}{$\begin{array}{l}\text { Rubber products, } 355 \\
\text { Estimate of returns to scale } \\
\text { Estimated coefficient on } \\
\text { capital }\end{array}$} & & & & & & & \\
\hline & 0.526 & 0.393 & 0.492 & 0.584 & 0.842 & 0.865 & 0.909 \\
\hline & $\begin{array}{c}0.208 \\
(1.37)\end{array}$ & $\begin{array}{c}0.228 \\
(1.56)\end{array}$ & $\begin{array}{r}0.261 \\
(1.89)\end{array}$ & $\begin{array}{c}0.332 \\
(2.31)\end{array}$ & $\begin{array}{r}0.447 \\
(2.83)\end{array}$ & $\begin{array}{c}0.390 \\
(2.34)\end{array}$ & $\begin{array}{c}0.341 \\
(1.62)\end{array}$ \\
\hline \multirow{3}{*}{$\begin{array}{l}\text { Plastics, } 356 \\
\text { Estimate of returns to scale } \\
\text { Estimated coefficient on } \\
\text { capital }\end{array}$} & & & & & & & \\
\hline & 0.274 & 0.556 & 0.871 & 1.051 & 1.048 & 0.871 & 1.003 \\
\hline & $\begin{array}{c}0.081 \\
(0.48)\end{array}$ & $\begin{array}{r}0.253 \\
(1.72)\end{array}$ & $\begin{array}{l}0.522 \\
(3.62)\end{array}$ & $\begin{array}{c}0.652 \\
(4.52)\end{array}$ & $\begin{array}{l}0.658 \\
(4.55)\end{array}$ & $\begin{array}{c}0.678 \\
(3.78)\end{array}$ & $\begin{array}{r}0.384 \\
(1.64)\end{array}$ \\
\hline
\end{tabular}


Table 2. (continued)

\begin{tabular}{|c|c|c|c|c|c|c|c|}
\hline \multirow{2}{*}{$\begin{array}{l}\text { Sector name and number } \\
\text { and sample statistic }\end{array}$} & \multicolumn{7}{|c|}{ Difference estimator } \\
\hline & $1 s t$ & $2 n d$ & $3 r d$ & $4 t h$ & 5 th & 6 th & $7 t h$ \\
\hline \multicolumn{8}{|l|}{$\begin{array}{l}\text { Nonmetallic mineral } \\
\text { products, } 369\end{array}$} \\
\hline Estimate of returns to scale & 0.427 & 0.594 & 0.599 & 0.774 & 0.636 & 0.572 & 0.868 \\
\hline $\begin{array}{l}\text { Estimated coefficient on } \\
\text { capital }\end{array}$ & $\begin{array}{r}0.120 \\
(1.18\rangle\end{array}$ & $\begin{array}{c}0.190 \\
(2.15)\end{array}$ & $\begin{array}{l}0.113 \\
(1.22)\end{array}$ & $\begin{array}{c}0.221 \\
(2.10)\end{array}$ & $\begin{array}{c}0.038 \\
(0.32)\end{array}$ & $\begin{array}{l}-0.039 \\
(-0.31)\end{array}$ & $\begin{array}{r}0.075 \\
(0.54)\end{array}$ \\
\hline \multicolumn{8}{|l|}{ Metal products, 381} \\
\hline $\begin{array}{l}\text { Estimate of returns to scale } \\
\text { Estimated coefficient on }\end{array}$ & 0.454 & 0.318 & 0.500 & 0.609 & 0.718 & 0.903 & 0.877 \\
\hline capital & $\begin{array}{r}0.164 \\
(2.07)\end{array}$ & $\begin{array}{l}-0.010 \\
(-0.16)\end{array}$ & $\begin{array}{r}0.020 \\
(0.31)\end{array}$ & $\begin{array}{l}0.156 \\
(2.55)\end{array}$ & $\begin{array}{l}0.186 \\
(3.04)\end{array}$ & $\begin{array}{r}0.233 \\
(3.64)\end{array}$ & $\begin{array}{r}0.249 \\
(3.11)\end{array}$ \\
\hline \multicolumn{8}{|l|}{ Nonelectric machinery, 382} \\
\hline $\begin{array}{l}\text { Estimate of returns to scale } \\
\text { Estimated coefficient on }\end{array}$ & 0.139 & 0.357 & 0.294 & 0.420 & 0.414 & 0.509 & 0.414 \\
\hline capital & $\begin{array}{r}0.059 \\
(0.47)\end{array}$ & $\begin{array}{r}0.064 \\
(0.54)\end{array}$ & $\begin{array}{l}-0.003 \\
(-0.03)\end{array}$ & $\begin{array}{c}0.053 \\
(0.50)\end{array}$ & $\begin{array}{r}0.053 \\
(0.48)\end{array}$ & $\begin{array}{c}0.063 \\
(0.53)\end{array}$ & $\begin{array}{r}0.118 \\
(0.78)\end{array}$ \\
\hline \multicolumn{8}{|l|}{ Electric machinery, 383} \\
\hline $\begin{array}{l}\text { Estimate of returns to scale } \\
\text { Estimated coefficient on }\end{array}$ & 0.104 & 0.726 & 0.867 & 0.885 & 0.681 & 0.871 & 0.715 \\
\hline capital & $\begin{array}{r}0.002 \\
(0.01)\end{array}$ & $\begin{array}{r}0.299 \\
(1.33)\end{array}$ & $\begin{array}{c}0.164 \\
(0.83)\end{array}$ & $\begin{array}{l}0.393 \\
(2.15)\end{array}$ & $\begin{array}{l}0.264 \\
\langle 1.73)\end{array}$ & $\begin{array}{l}0.278 \\
(1.92)\end{array}$ & $\begin{array}{r}0.299 \\
(1.29)\end{array}$ \\
\hline \multicolumn{8}{|l|}{$\begin{array}{l}\text { Transportation equipment, } \\
384\end{array}$} \\
\hline $\begin{array}{l}\text { Estimate of returns to scale } \\
\text { Estimated coefficient on }\end{array}$ & 0.718 & 0.786 & 0.900 & 1.030 & 1.157 & 0.879 & 1.264 \\
\hline capital & $\begin{array}{c}0.092 \\
\{0.39\}\end{array}$ & $\begin{array}{r}0.029 \\
(0.16)\end{array}$ & $\begin{array}{r}0.239 \\
\langle 1.31\rangle\end{array}$ & $\begin{array}{c}0.364 \\
(2.02)\end{array}$ & $\begin{array}{r}0.430 \\
(2.51)\end{array}$ & $\begin{array}{r}0.463 \\
(2.12)\end{array}$ & $\begin{array}{r}0.151 \\
(0.60)\end{array}$ \\
\hline $\begin{array}{l}\text { Cross-industry means } \\
\text { Estimate of returns to scale } \\
\text { Estimated coefficient on }\end{array}$ & 0.409 & 0.544 & 0.669 & 0.751 & 0.780 & 0.775 & 0.845 \\
\hline capital & 0.114 & 0.149 & 0.182 & 0.243 & 0.244 & 0.223 & 0.199 \\
\hline
\end{tabular}

Note: Estimates are based on balanced-panel data; only plants that appear in all sample years are included, and industries with fewer than 20 such plants are not analyzed. Although not reported, time dummies are included in the regressions. $t$-ratios are in parentheses.

Source: Authors' calculations.

the extended sample increases returns to scale, and increases in returns to scale are concentrated among the shorter differences. Note, however, that the disparity in the number of firms between the balanced and extended samples declines with the length of the difference, disappearing entirely for the longest difference (the seventh).

The results based on extended panels may themselves be subject to bias if plants present in year $t-j$, but not in year $t$, differ systematically from those that survive to year $t$. To investigate this effect, we use Heckman's (1979) twostep procedure. The probit equation we use to construct our Mills ratios is

$$
S_{i}=\alpha+\beta_{80} D_{80, i}+\beta_{81} D_{81, i}+\beta_{T L} T L_{i}+\varphi_{i}
$$

where $S_{i}$ is a latent variable that is positive if, and only if, exit occurs; $D_{80, i}$ and $D_{81, i}$ are dummies that indicate whether the plant was a new entrant in 1980 or 
Table 3. The Proportional Increase in Estimated Returns to Scale Using Extended Data Compared with Using Balanced Data for Chilean Manufacturing Industries, 1979-86

\begin{tabular}{|c|c|c|c|c|c|c|c|}
\hline \multirow[b]{2}{*}{ Sector name and number } & \multicolumn{7}{|c|}{ Difference estimator } \\
\hline & $1 s t$ & $2 n d$ & $3 r d$ & $4 t h$ & $5 t h$ & $6 t h$ & $7 t h$ \\
\hline Food, 312 & 0.0743 & 0.0674 & 0.0150 & -0.0067 & 0.0370 & 0.0206 & 0.0000 \\
\hline Beverages, 313 & -0.1059 & -0.0201 & -0.1415 & -0.2007 & -0.2199 & -0.0450 & 0.0000 \\
\hline Textiles, 321 & -0.1172 & 0.0029 & 0.0227 & 0.1170 & 0.0349 & 0.0137 & 0.0000 \\
\hline Apparel, 322 & 0.4010 & 0.0436 & 0.1107 & -0.1173 & -0.0510 & -0.0365 & 0.0000 \\
\hline Footwear, 324 & 0.7217 & 0.4870 & 0.2290 & 0.1432 & 0.0374 & -0.0339 & 0.0000 \\
\hline Wood products, 331 & 0.2628 & 0.0476 & -0.0752 & -0.1400 & -0.0790 & -0.3020 & 0.0000 \\
\hline Furniture, 332 & 0.1491 & 0.3529 & 0.0047 & 0.0606 & -0.0907 & -0.0309 & 0.0000 \\
\hline Printing, 342 & 0.2674 & 0.0411 & -0.0330 & 0.1120 & 0.0710 & -0.0201 & 0.0000 \\
\hline Miscellaneous chemicals, 352 & 0.6220 & 0.0075 & 0.1979 & 0.0691 & -0.1417 & -0.0817 & 0.0000 \\
\hline Rubber products, 355 & -0.0815 & 0.0360 & 0.0009 & 0.0068 & 0.0496 & 0.0739 & 0.0000 \\
\hline Plastics, 356 & 1.2964 & 0.2936 & 0.0778 & -0.1162 & -0.0655 & -0.0734 & 0.0000 \\
\hline Nonmetallic mineral products, 369 & 0.2766 & 0.1216 & -0.2886 & 0.0074 & -0.0737 & 0.1250 & 0.0000 \\
\hline Metal products, 381 & -0.0431 & 0.2928 & 0.1959 & 0.1331 & 0.0691 & 0.0047 & 0.0000 \\
\hline Nonelectric machinery, 382 & 1.4029 & 0.4285 & 0.7984 & 0.3170 & 0.2054 & 0.1187 & 0.0000 \\
\hline Electric machinery, 383 & 5.1933 & 0.8263 & -0.0795 & -0.1339 & -0.0860 & -0.0065 & 0.0000 \\
\hline Transportation equipment, 384 & -0.2148 & -0.0210 & 0.0234 & -0.0216 & -0.0603 & -0.0321 & 0.0000 \\
\hline
\end{tabular}

Note: Although not reported, time dummies are included in the regressions.

Source: Authors' calculations. 
1981 ; and $T L_{i}$ is the total labor force of the firm in the base year, a predetermined proxy for firm size. A different probit is fit in cross-section for each of the years associated with the fifth-, sixth-, and seventh-difference equations available in the extended sample. ${ }^{8}$

Table 4 reports estimates of the coefficient on the proxy for firm size, $\beta_{T L}$, by industry and time period. We focus on the longer time spans because they are most likely to be contaminated by selectivity bias (additional reasons are given below). Note that whether a plant was a new entrant in 1979 cannot be discerned from our sample. As predicted by recent theories of industrial evolution, large firms are significantly less likely to exit in every year for almost all industries. From Stigler's (1958) perspective, the coefficient on our proxy for firm size is itself an indicator of the importance of scale economies. In fact, it is probably a better indicator than the one Stigler used, because it describes the behavior of individual firms rather than that of the size distribution. Nonetheless, like crosssectional estimators of returns to scale, the estimated coefficient on the proxy for firm size is contaminated by the Demsetz effect if inherently efficient plants last longer and grow bigger. This is presumably one reason our coefficients on firm size are almost all negative, and we will return to this point later. Finally, although the number of new entrants is typically too small to permit accurate estimation of the coefficients on the new entrant dummies $\left(\beta_{80}\right.$ and $\left.\beta_{81}\right)$, whenever estimates of these coefficients (not reported here) are significant, they are always positive.

The dependence of survival rates on size does not itself imply that estimates of the production function are biased. To address this question, we use our estimates of equation 7 to construct Mills ratios for sample-selection corrections of the individual long-difference equations. Table 5 shows the increase in estimated returns to scale for each long-difference equation when the sample-selection correction is employed: the corrections are almost uniformly quite small. Furthermore, formal tests for selectivity bias in the context of our GMM estimators confirm that this problem is generally unimportant in extended samples. ${ }^{9}$ This finding contrasts with that of Olley and Pakes (1992), possibly because their estimator exploited both between-plant and within-plant variation, whereas our estimators remove time-invariant plant effects entirely. That is, the model used by Olley and Pakes will pick up selectivity effects if failing firms systematically

8. It would be possible to reap an efficiency gain by pooling these regressions and using a random effects probit estimator. If this were done in the manner suggested by Chamberlain (1980), it would also be possible to allow for effects that are correlated with the explanatory variables. Our intuition is that these extensions will matter more for the coefficients of the probit than for the Mills ratio, so we have not pursued them.

9. These tests are based on the coefficients and standard errors obtained for Mills ratios that were added to equation 1 . Because this equation was estimated using the GMM, no additional correction for heteroscedasticity was necessary. Only 3 of the 16 industries yielded $t$-ratios greater than 2 in absolute value, and these only marginally so. Because all of the $t$-ratios are independent and asymptotically normal, we can square them and sum them up to obtain a Chi-square statistic for the null that selectivity bias is not important in any industry. This statistic was 27.11 , which has a $P$-value of 0.0403 . 
Table 4. Estimates of the Coefficient on the Proxy for Firm Size for Chilean Manufacturing Industries, 1979-86

\begin{tabular}{|c|c|c|c|c|c|c|}
\hline \multirow{2}{*}{$\begin{array}{l}\text { Sector name and number } \\
\text { and sample statistic }\end{array}$} & \multicolumn{6}{|c|}{ Time period } \\
\hline & $1979-84$ & $1980-85$ & $1981-86$ & $1979-85$ & $1980-86$ & $1979-86$ \\
\hline \multicolumn{7}{|l|}{ Food, 312} \\
\hline Estimate & -0.33 & -0.31 & -0.32 & -0.33 & -0.28 & -0.29 \\
\hline Ratio over standard error & -8.21 & -7.08 & -7.24 & -8.32 & -6.80 & -7.87 \\
\hline \multicolumn{7}{|l|}{ Beverages, 313} \\
\hline Estimate & -0.49 & -0.27 & -0.36 & -0.48 & -0.33 & -0.50 \\
\hline Ratio over standard error & -5.19 & -2.84 & -3.26 & -5.15 & -3.35 & -5.29 \\
\hline \multicolumn{7}{|l|}{ Textiles, 321} \\
\hline Estimate & -0.15 & -0.27 & -0.29 & -0.19 & -0.28 & -0.21 \\
\hline Ratio over standard error & -2.92 & -4.49 & -4.49 & -3.61 & -4.73 & -4.04 \\
\hline \multicolumn{7}{|l|}{ Apparel, 322} \\
\hline Estimate & -0.26 & -0.21 & -0.30 & -0.26 & -0.22 & -0.25 \\
\hline Ratio over standard error & -3.93 & -3.07 & -3.82 & -3.98 & -3.16 & -3.77 \\
\hline \multicolumn{7}{|l|}{ Footwear, 324} \\
\hline Estimate & -0.31 & -0.26 & -0.30 & -0.33 & -0.32 & -0.38 \\
\hline Ratio over standard error & -3.00 & -2.28 & -2.43 & -3.26 & -2.75 & -3.65 \\
\hline \multicolumn{7}{|l|}{ Wood products, 331} \\
\hline Estimate & -0.21 & -0.22 & -0.37 & -0.22 & -0.25 & -0.21 \\
\hline Ratio over standard error & -3.92 & -3.35 & -5.23 & -4.00 & -3.75 & -3.74 \\
\hline \multicolumn{7}{|l|}{ Furniture, 332} \\
\hline Estimate & -0.38 & -0.53 & -0.72 & -0.39 & -0.22 & -0.47 \\
\hline Ratio over standard error & -3.17 & -3.94 & -4.85 & -3.27 & -4.46 & -3.86 \\
\hline \multicolumn{7}{|l|}{ Printing, 342} \\
\hline Estimate & -0.26 & -0.39 & -0.58 & -0.29 & -0.40 & -0.31 \\
\hline Ratio over standard error & -2.92 & -3.87 & -4.84 & -3.31 & -4.09 & -3.51 \\
\hline \multicolumn{7}{|l|}{ Miscellaneous chemicals, 352} \\
\hline Estimate & -0.31 & -0.36 & -0.33 & -0.26 & -0.43 & -0.32 \\
\hline Ratio over standard error & -3.10 & -3.18 & -2.95 & -2.76 & -3.85 & -3.40 \\
\hline \multicolumn{7}{|l|}{ Rubber products, 355} \\
\hline Estimate & 0.10 & $\begin{array}{l}-0.00 \\
-0.01\end{array}$ & 0.13 & 0.03 & 0.09 & 0.19 \\
\hline \multirow{2}{*}{\multicolumn{6}{|c|}{ Plastics, 356}} & 1.34 \\
\hline & & -0.43 & -0.37 & & & \\
\hline Ratio over standard error & -2.94 & -3.10 & -2.90 & -2.72 & -3.41 & -2.89 \\
\hline \multicolumn{7}{|l|}{$\begin{array}{l}\text { Nonmetallic mineral products, } \\
369\end{array}$} \\
\hline Estimate & -0.41 & -0.54 & -0.43 & -0.36 & -0.45 & -0.29 \\
\hline Ratio over standard error & -3.22 & -4.05 & -3.12 & -2.92 & -3.67 & -2.49 \\
\hline \multicolumn{7}{|l|}{ Metal products, 381} \\
\hline Estimate & -0.46 & -0.53 & -0.45 & -0.47 & -0.44 & -0.40 \\
\hline Ratio over standard error & -6.88 & -7.25 & -6.06 & -7.11 & -6.41 & -6.23 \\
\hline \multicolumn{7}{|l|}{ Nonelectric machinery, 382} \\
\hline Estimate & -0.32 & -0.30 & -0.02 & -0.33 & -0.12 & -0.20 \\
\hline Ratio over standard error & -3.14 & -2.60 & -0.26 & -3.23 & -1.24 & -2.05 \\
\hline \multicolumn{7}{|l|}{ Electric machinery, 383} \\
\hline Estimate & -0.28 & -0.35 & -0.49 & -0.28 & -0.37 & -0.31 \\
\hline Ratio over standard error & -2.46 & -2.40 & -2.74 & -2.46 & -2.57 & -2.64 \\
\hline \multicolumn{7}{|l|}{$\begin{array}{l}\text { Transportation equipment, } \\
384\end{array}$} \\
\hline Estimate & -0.28 & -0.62 & -0.34 & -0.41 & -0.34 & -0.26 \\
\hline Ratio over standard error & -1.77 & -2.54 & -1.59 & -2.38 & -1.59 & -1.56 \\
\hline
\end{tabular}

Note: Estimates are obtained from probit analysis of equation 7 , using the extended sample. Although not reported, time dummies are included in the regressions.

Source: Authors' calculations. 
Table 5. The Proportional Increase in Estimated Returns to Scale Caused by Sample-Selection Corrections of Long-Difference Estimators for the Extended Sample for Chilean Manufacturing Industries, 1979-86

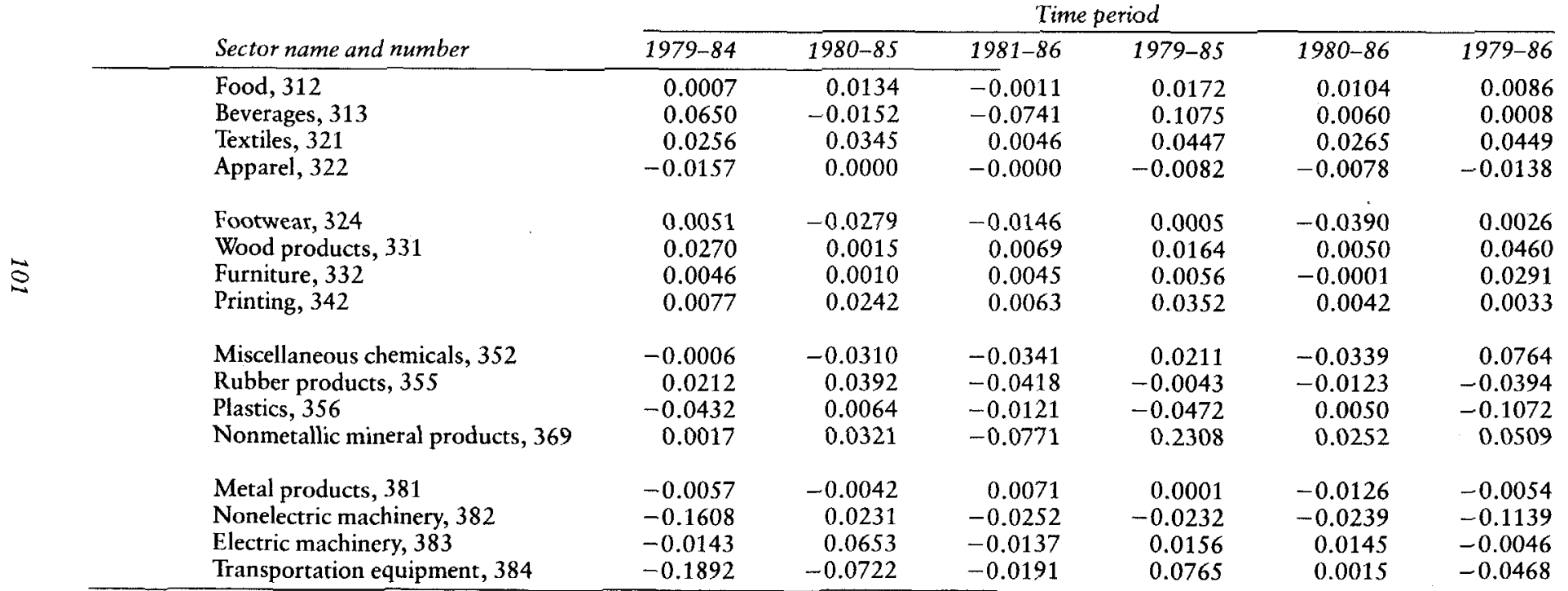

Note: The time periods indicate the years between which the differences were taken. Although not reported, time dummies are included in the regressions. Source: Authors' calculations. 
differ from others in terms of efficiency levels, whereas our model is sensitive to selectivity bias only if failing plants exhibit lower or higher incremental output per incremental unit of input.

\section{Robust Estimators}

We now turn to the GMM estimates. If the instruments at our disposal (machinery and equipment growth, real wage rates, and employment growth) are valid, GMM estimates are robust with respect to measurement error in the capital stock and heteroscedasticity. Because the GMM estimates are based on the extended sample, the results are robust with respect to selectivity effects as well. For several reasons, we hereafter limit the analysis to estimators that pool only the longer differences (that is, fifth, sixth, and seventh differences). ${ }^{10}$ First, gestation lags in capital stocks probably make the association between the true flow of capital services and measured changes in capital particularly weak over short periods. Second, by limiting the analysis to long differences, we effectively leapfrog the severe recession that bottomed out during 1982 and $1983 .{ }^{11}$ Doing so is desirable because rapidly shrinking industries are likely to have extreme excess capacity, and under these conditions our instruments probably would not do an adequate job of recovering the true flow of capital services.

Overview of the results. Findings for all three-digit industries with sufficient data are reported in table 6. It appears that the GMM estimators do lessen measurement error bias. In particular, the elimination of measurement error should increase the coefficient on capital. This is precisely the pattern we find when comparing estimates based on seventh differences in table 6 with those in table 2. (This comparison is made for seventh differences in order to hold the sample composition constant across estimators.) Theory also predicts that, on average, estimates of returns to scale should rise when measurement error is eliminated. This effect does occur in 9 of the 16 industries when going from ous to GMM estimates. The increase is less impressive than that for the capital coefficient because, as expected (see appendix), the higher estimates for capital coefficients are somewhat offset by decreases in the labor coefficients.

There remains a troubling feature of the GMM results, however. Recall that we attributed the systematic distinctions across simple difference estimators in table 2 to biases induced by measurement error or selectivity problems. The GMM estimator applied to the extended sample (with and without Mills ratio corrections) is designed to eliminate these sources of bias, thus eliminating the system-

10. The sample sizes given in table 6 are for the number of firms that appear in at least one of the equations involved in the GMM estimator. The samples differ somewhat from the samples employed for the simple difference estimators, because the frequency of missing values for the instrumental variables differs from that of the variables being instrumented.

11. Only two of the three fifth-difference equations are used in the estimator that encompasses all long differences. This is because the remaining fifth-difference equation is redundant when both sixthdifference equations are included. 
Table 6. Seventh-Difference GMM Estimates for Three-Digit Chilean Manufacturing Industries, 1979-86

\begin{tabular}{|c|c|c|c|c|}
\hline \multirow[b]{2}{*}{ Sector name and number } & \multirow[b]{2}{*}{$\begin{array}{l}\text { Number } \\
\text { of plants }\end{array}$} & \multicolumn{2}{|c|}{$\begin{array}{l}\text { Estimated } \\
\text { coefficient }\end{array}$} & \multirow[b]{2}{*}{$\begin{array}{l}\text { Returns } \\
\text { to scale }\end{array}$} \\
\hline & & $\begin{array}{l}\text { On } \\
\text { labor }\end{array}$ & $\begin{array}{c}\text { On } \\
\text { capital }\end{array}$ & \\
\hline Food, 312 & 538 & $\begin{array}{c}0.502 \\
(0.072)\end{array}$ & $\begin{array}{c}0.407 \\
(0.078)\end{array}$ & $\begin{array}{c}0.909 \\
(0.083)\end{array}$ \\
\hline Beverages, $313^{a}$ & 42 & $\begin{array}{c}0.719 \\
(0.263)\end{array}$ & $\begin{array}{c}0.575 \\
(0.332)\end{array}$ & $\begin{array}{c}1.294 \\
(0.486)\end{array}$ \\
\hline Textiles, 321 & 138 & $\begin{array}{c}0.511 \\
(0.133)\end{array}$ & $\begin{array}{c}0.304 \\
(0.132)\end{array}$ & $\begin{array}{c}0.815 \\
(0.160)\end{array}$ \\
\hline Apparel, 322 & 100 & $\begin{array}{c}0.815 \\
(0.138)\end{array}$ & $\begin{array}{c}0.219 \\
(0.160)\end{array}$ & $\begin{array}{c}1.034 \\
(0.152)\end{array}$ \\
\hline Footwear, 324 & 48 & $\begin{array}{c}0.638 \\
(0.192)\end{array}$ & $\begin{array}{c}0.396 \\
(0.109)\end{array}$ & $\begin{array}{c}1.033 \\
(0.219)\end{array}$ \\
\hline Wood products, $331^{a}$ & 91 & $\begin{array}{c}0.772 \\
(0.240)\end{array}$ & $\begin{array}{c}0.119 \\
(0.227)\end{array}$ & $\begin{array}{c}0.890 \\
(0.382)\end{array}$ \\
\hline Furniture, 332 & 28 & $\begin{array}{c}0.398 \\
(0.407)\end{array}$ & $\begin{array}{c}0.774 \\
(0.389)\end{array}$ & $\begin{array}{c}1.172 \\
(0.210)\end{array}$ \\
\hline Printing, $342^{\mathrm{a}}$ & 65 & $\begin{array}{c}0.566 \\
(0.107)\end{array}$ & $\begin{array}{c}0.196 \\
(0.119)\end{array}$ & $\begin{array}{c}0.762 \\
(0.134)\end{array}$ \\
\hline Miscellaneous chemicals, $352^{a}$ & 74 & $\begin{array}{c}0.155 \\
(0.138)\end{array}$ & $\begin{array}{c}0.254 \\
(0.162)\end{array}$ & $\begin{array}{c}0.409 \\
(0.202)\end{array}$ \\
\hline Rubber products, 355 & 28 & $\begin{array}{c}0.343 \\
(0.228)\end{array}$ & $\begin{array}{c}0.544 \\
(0.293)\end{array}$ & $\begin{array}{c}0.887 \\
(0.300)\end{array}$ \\
\hline Plastics, 356 & 43 & $\begin{array}{c}0.990 \\
(0.404)\end{array}$ & $\begin{array}{c}0.018 \\
(0.256)\end{array}$ & $\begin{array}{c}1.008 \\
(0.319)\end{array}$ \\
\hline Nonmetallic mineral products, 369 & 30 & $\begin{array}{c}0.649 \\
(0.292)\end{array}$ & $\begin{array}{c}0.417 \\
(0.214)\end{array}$ & $\begin{array}{c}1.066 \\
(0.330)\end{array}$ \\
\hline Metal products, 381 & 127 & $\begin{array}{c}0.696 \\
(0.139)\end{array}$ & $\begin{array}{c}0.470 \\
(0.147)\end{array}$ & $\begin{array}{c}1.166 \\
(0.160)\end{array}$ \\
\hline Nonelectric machinery, 382 & 25 & $\begin{array}{c}-0.086 \\
(0.378)\end{array}$ & $\begin{array}{c}0.462 \\
(0.259)\end{array}$ & $\begin{array}{c}0.376 \\
(0.308)\end{array}$ \\
\hline Electric machinery, 383 & 23 & $\begin{array}{c}0.513 \\
(0.174)\end{array}$ & $\begin{array}{c}0.544 \\
(0.243)\end{array}$ & $\begin{array}{c}1.057 \\
(0.302)\end{array}$ \\
\hline Transportation equipment, 384 & 28 & $\begin{array}{c}0.870 \\
(0.188)\end{array}$ & $\begin{array}{c}0.347 \\
(0.162)\end{array}$ & $\begin{array}{c}1.217 \\
(0.136)\end{array}$ \\
\hline
\end{tabular}

Note: Estimates are based on extended data-all plants for which data are available in the relevant years. Although not reported, time dummies are included in the regressions. $t$-ratios are in parentheses. a. The industry exhibited average rates of value-added growth that were less than -40 percent in real terms over 1979-86.

Source: Authors' calculations.

atic association between the sample period and estimated returns to scale. Nonetheless, estimates of returns to scale based on seventh differences; on pooled sixth and seventh differences; and on pooled fifth, sixth, and seventh differences vary considerably (detailed comparisons appear in Tybout and Westbrook 1992). Griliches and Mairesse (1988) report a similar finding in their threecountry study of panel data on the manufacturing sector. Similar results emerge when we apply the GMM estimator to four-digit industries for which we have adequate data. This finding could mean that estimates exploiting fifth and sixth 
Table 7. Seventh-Difference GMM Estimates for Four-Digit Chilean Manufacturing Industries, 1979-86

\begin{tabular}{|c|c|c|c|c|}
\hline \multirow[b]{2}{*}{ Sector name and number } & \multirow[b]{2}{*}{$\begin{array}{l}\text { Number } \\
\text { of plants }\end{array}$} & \multicolumn{2}{|c|}{$\begin{array}{l}\text { Estimated } \\
\text { coefficient }\end{array}$} & \multirow[b]{2}{*}{$\begin{array}{l}\text { Returns } \\
\text { to scale }\end{array}$} \\
\hline & & $\begin{array}{c}\text { On } \\
\text { labor }\end{array}$ & $\begin{array}{c}\text { On } \\
\text { capital }\end{array}$ & \\
\hline Meatpacking, 3111 & 43 & $\begin{array}{c}0.795 \\
(0.191)\end{array}$ & $\begin{array}{c}0.580 \\
(0.099)\end{array}$ & $\begin{array}{c}1.375 \\
(0.210)\end{array}$ \\
\hline Fruit and vegetable canning, 3113 & 25 & $\begin{array}{c}0.906 \\
(0.213)\end{array}$ & $\begin{array}{r}-0.674 \\
(0.394)\end{array}$ & $\begin{array}{l}0.232 \\
(0.344)\end{array}$ \\
\hline Cooking oils and fats, 3115 & 20 & $\begin{array}{c}0.193 \\
(0.454)\end{array}$ & $\begin{array}{c}0.490 \\
(0.413)\end{array}$ & $\begin{array}{c}0.683 \\
(0.604)\end{array}$ \\
\hline Grain mills, 3116 & 42 & $\begin{array}{c}0.182 \\
(0.184)\end{array}$ & $\begin{array}{c}0.569 \\
(0.247)\end{array}$ & $\begin{array}{c}0.750 \\
(0.288)\end{array}$ \\
\hline Bakeries, 3117 & 321 & $\begin{array}{c}0.775 \\
(0.088)\end{array}$ & $\begin{array}{c}0.335 \\
(0.109)\end{array}$ & $\begin{array}{c}1.110 \\
(0.106)\end{array}$ \\
\hline Wineries, 3132 & 22 & $\begin{array}{c}0.860 \\
(0.157)\end{array}$ & $\begin{array}{c}0.131 \\
(0.346)\end{array}$ & $\begin{array}{c}0.991 \\
(0.256)\end{array}$ \\
\hline Spinning and weaving, 3211 & 65 & $\begin{array}{c}0.459 \\
(0.175)\end{array}$ & $\begin{array}{c}0.263 \\
(0.166)\end{array}$ & $\begin{array}{c}0.722 \\
(0.245)\end{array}$ \\
\hline Knitting, 3213 & 44 & $\begin{array}{c}0.815 \\
(0.309)\end{array}$ & $\begin{array}{c}0.563 \\
(0.257)\end{array}$ & $\begin{array}{c}1.378 \\
(0.299)\end{array}$ \\
\hline Sawmills, 3311a & 79 & $\begin{array}{c}0.694 \\
(0.317)\end{array}$ & $\begin{array}{c}0.053 \\
(0.263)\end{array}$ & $\begin{array}{c}0.747 \\
(0.500)\end{array}$ \\
\hline Pharmaceuticals, $3522^{\mathrm{a}}$ & 28 & $\begin{array}{c}-0.041 \\
(0.160)\end{array}$ & $\begin{array}{c}-0.530 \\
(0.229)\end{array}$ & $\begin{array}{r}-0.571 \\
(0.281)\end{array}$ \\
\hline Structural metal, 3813 & 25 & $\begin{array}{c}0.699 \\
\langle 0.137\rangle\end{array}$ & $\begin{array}{c}0.940 \\
(0.087)\end{array}$ & $\begin{array}{c}1.640 \\
(0.132)\end{array}$ \\
\hline Miscellaneous metal products, 3819 & 28 & $\begin{array}{c}0.662 \\
(0.663)\end{array}$ & $\begin{array}{c}0.297 \\
(0.204)\end{array}$ & $\begin{array}{c}0.959 \\
(0.543)\end{array}$ \\
\hline Automobiles, 3843 & 23 & $\begin{array}{c}1.288 \\
(0.217)\end{array}$ & $\begin{array}{c}-0.287 \\
(0.316)\end{array}$ & $\begin{array}{c}1.001 \\
(0.229)\end{array}$ \\
\hline
\end{tabular}

Note: Estimates are based on extended data-all plants for which data are available in the relevant years. Although not reported, time dummies are included in the regressions. $t$-ratios are in parentheses. a. The industry exhibited average rates of value-added growth that were less than -40 percent in real terms over 1979-86.

Source: Authors' calculations.

differences are relatively sensitive to biases deriving from gestation lags and lingering effects of the recession. Whatever the explanation, it appears that the instruments are not always effective in the shorter differences. Accordingly, in most of what follows we focus on the seventh-difference estimators, sacrificing degrees of freedom for apparent reduction in bias (see table 7 for seventhdifference estimates on four-digit industries).

GMM returns to scale. We have already seen that implausibly low returns to scale result from simple difference and within estimators. Are the seventhdifference GMM estimates similarly low? In table 6 it appears that some of them clearly are. However, with but one exception, the industries with very low (less than 0.8 ) estimates of returns to scale exhibited average rates of value-added 
growth that were less than -40 percent. (The excepted industry, nonelectric machinery, has only 25 observations.) The rapidly shrinking industries are identified in tables 6 and 7. They are likely to have extreme excess capacity, and our instruments are unlikely to correct for the discrepancy between true and measured capital flows.

Leaving the rapidly shrinking groups aside, the estimates of returns to scale for three-digit industries are fairly evenly distributed over the plausible range of 0.8 to 1.2 , and none is more than two standard deviations from constant returns to scale (table 6). Also, unlike other estimates that are based on temporal variation in the data (tables 1 and 2), the relative elasticities of output with respect to labor and capital seem closer to those one might infer from factor shares under the assumption of competitive profit maximization. Capital's share in value added for the manufacturing sector as a whole was in the neighborhood of 0.6 to 0.7 during the sample period.

Comparing GMM and oLs estimates of returns to scale, we find evidence that the combined influence of the Demsetz effect and start-up costs is important. Each of these factors tends to push ols estimates of returns to scale upward, but GMM removes them both. Comparing tables 1 and 6 , we find that ols estimates exceed GMM estimates in 13 of the 16 industries. Moreover, the contrast between these tables would probably have been even more striking if the oLs results were corrected for measurement error, which tends to bias estimates of returns to scale downward.

Our (more disaggregated) four-digit industry results (table 7) provide additional details on the particular products generating increasing returns and are less subject to the aggregation biases caused by heterogeneous products (via price deflators) and technologies (via variable coefficients). Results at the fourdigit level may also be useful in assessing the plausibility of the changing composition of three-digit industries as the explanation for within-industry heterogeneity over time. Note, for example, that structural metal products (bridges, container tanks, metal door frames) are partly responsible for the high estimate of returns to scale for metal products. Some sectors that show decreasing returns at the three-digit level show increasing returns for particular products. Notably, meatpacking and bakeries are sources of scale economies even though the food industry (312) shows returns to scale slightly below unity. Also, although the textile industry shows decreasing returns overall, knitting shows scale economies.

Our methodology is designed to reveal the plant-level scale effects that are realized as industries move through business cycles and regime changes. Hence, unlike in engineering studies, the plant-level scale effects do not capture sunk start-up costs, and they do not necessarily reflect the scale economies that might be reaped if existing plants were torn down and replaced with bigger ones. Nonetheless, it is interesting to ask whether there is some correspondence between the ranking of industries according to our estimates and rankings based on engineering studies of firms in industrial countries. The latter tend to find 
that, among industries in our analysis, scale economies are most important in automobiles, certain metal products, iron and steel, electric machinery, and chemicals. This list is based on surveys by Pratten (1988) and Berry (1992) and Scherer and Ross's (1990) summary of engineering studies. In table 6, it is noteworthy that transportation equipment, metal products, and electric machinery are ranked among the top five (excluding rapidly shrinking industries) estimates of returns to scale.

Finally, we may test the plausibility of our GMM estimates by asking whether those industries where failure probabilities fall most rapidly with plant size are also the ones with the highest estimated returns to scale. To this end, we look at the Spearman rank correlation coefficient between seventh-difference estimates of the coefficient on the proxy for firm size $\left(-\beta_{T L}\right)$, from table 4 , and seventhdifference estimates of returns to scale, from table 6 . Remarkably, this coefficient is 0.69 with a $t$-ratio of 4.41 when 15 industries are used and 0.80 with a $t$-ratio of 5.37 when the four rapidly shrinking industries are excluded. ${ }^{12}$ This is additional evidence that our GMM estimates are plausible and suggests that our version of Stigler's survivor test has empirical validity. In principle spurious association between the GMM estimator of returns to scale and the coefficient on firm size might be caused by selectivity bias in the GMM estimates. However, we have tested for such bias and found it to be unimportant.

\section{ConClusions}

This study is the first we are aware of to provide systematic panel-based econometric estimates of the returns to scale in manufacturing industries in a developing country. As such, we believe it sheds new light on several issues of interest to policymakers. One issue is whether increases in size cause improvements in efficiency. If such causality is present over the production ranges in which plants operate, there are productivity gains associated with policies that promote bigness in manufacturing plants. We find that although several fourdigit sectors show increasing returns, general expansion of the manufacturing sector cannot be expected to yield strong plant-level scale economies. Specifically, if we take our best estimates at face value, they imply that the returns to scale in manufacturing are scattered across the range of 0.8 to 1.2 at the threedigit level, and 0.7 to 1.6 at the four-digit level. None of the estimates of returns to scale using three-digit industries, and only two of the estimates using fourdigit industries, are significantly different from unity. The findings complement those of a related study where we found that Mexico's dramatic trade liberalization was associated with modest increases in scale efficiency. The technical

12. The correlations reported here are based on the three-digit industries in table 6 . It was not possible to estimate our probit model for transport equipment, given the small number of exiting plants. Nor did we estimate the production technology for miscellaneous manufacturing. 
efficiency gains we measured were far more dramatic than the gains recorded here (Tybout and Westbrook 1992). ${ }^{13}$

Our results do not rule out several forms of scale economies. Start-up costs are removed along with other time-invariant components of the data, so if these are a source of increasing returns, our GMM estimates are too low. Put differently, the figures we report describe increments to output per unit of increment to inputs. And our results do not speak to the issue of external returns to scale, which might derive from information spillovers, infrastructure, induced expansion of the intermediate goods menu, or other forces. These factors, being common to all plants, are picked up along with general productivity growth in our intercept and time dummies.

Another issue we address is whether efficiency causes plant growth, as Demsetz and others have argued. An affirmative answer means that positive correlations between size and profitability need not constitute a case for antitrust activity. By comparing technology estimators that control for plant-specific efficiency effects with those that do not, we find evidence that Demsetz effects may indeed be important, although it was not possible to isolate them from other time-invariant unobservables, such as start-up costs.

As a by-product, our analysis has generated several findings of methodological interest. It appears that Stigler's survival test may indeed be useful as a quick first pass on the empirical importance of returns to scale. However, unlike earlier applications of this test that are based on plant-size distributions, our results suggest that the sensitivity of failure probabilities to plant size could be used as an index of returns to scale. And we have shown that long-difference estimators-especially in the context of GMM-do a reasonable job of controlling for measurement error bias and do not appear sensitive to selectivity bias. Five years of data do not appear to be enough, but seven years do fairly well.

\section{Appendix. The Asymptotic Bias of Difference Estimators With Measurement ERror}

Generalizing Griliches and Hausman (1986), it can be shown that the biases in coefficient estimators based on the $j$ th difference are as follows:

$$
\begin{array}{ll}
\operatorname{plim}_{n \rightarrow \infty}\left(a_{j}-\alpha\right)=2\left(1-r_{j}\right) \sigma_{\nu}^{2} \gamma_{j} \beta / \operatorname{var}\left(d^{j} K_{p}\right) & j=1, T-1 \\
\operatorname{plim}_{n \rightarrow \infty}\left(b_{j}-\beta\right)=-2\left(1-r_{j}\right) \sigma_{\nu}^{2} \beta / \operatorname{var}\left(d^{j} K_{p}\right) & j=1, T-1 .
\end{array}
$$

Here $\gamma_{j}$ is the population regression coefficient when $d^{j} L$ is projected on $d^{j} K$ and time dummies. $\mathrm{E}\left(\nu_{i t}\right)=0, \operatorname{var}\left(\nu_{i t}\right)=\sigma_{\nu}^{2}, r_{j}=\operatorname{corr}\left(\nu_{i t}, \nu_{i t-j}\right)$, and $\operatorname{var}\left(d^{j} K_{p}\right)$ is the 
Table A-1. Evidence on the Relation between Difference Length and Bias in the Estimates of Returns to Scale for Chilean Manufacturing Industries, 1979-86

\begin{tabular}{|c|c|c|c|c|c|c|c|c|}
\hline \multirow[b]{2}{*}{ Sector name and number } & \multirow{2}{*}{$\begin{array}{l}\text { Within- } \\
\text { plant } \\
\text { estimator }\end{array}$} & \multicolumn{7}{|c|}{ Difference estimator } \\
\hline & & $1 s t$ & $2 n d$ & $3 r d$ & $4 t h$ & $S t h$ & $6 t h$ & $7 t h$ \\
\hline \multicolumn{9}{|c|}{ Part A. Consistent point estimates of the correlation between labor and capital } \\
\hline $\begin{array}{l}\text { Food, } 312 \\
\text { Beverages, } 313 \\
\text { 'Textiles, } 321 \\
\text { Apparel, } 322\end{array}$ & $\begin{array}{l}0.1447 \\
0.0413 \\
0.1647 \\
0.2046\end{array}$ & $\begin{array}{r}0.0364 \\
-0.0112 \\
0.0291 \\
0.0451\end{array}$ & $\begin{array}{l}0.0880 \\
0.0069 \\
0.1091 \\
0.1406\end{array}$ & $\begin{array}{l}0.1246 \\
0.0572 \\
0.1529 \\
0.2071\end{array}$ & $\begin{array}{l}0.1766 \\
0.0655 \\
0.1868 \\
0.2220\end{array}$ & $\begin{array}{l}0.2023 \\
0.0343 \\
0.2234 \\
0.2885\end{array}$ & $\begin{array}{l}0.2394 \\
0.0303 \\
0.2719 \\
0.3127\end{array}$ & $\begin{array}{l}0.2471 \\
0.1401 \\
0.3530 \\
0.3248\end{array}$ \\
\hline $\begin{array}{l}\text { Footwear, } 324 \\
\text { Wood products, } 331 \\
\text { Furniture, } 332 \\
\text { Printing, } 342\end{array}$ & $\begin{array}{l}0.2417 \\
0.1616 \\
0.1653 \\
0.1956\end{array}$ & $\begin{array}{l}0.0099 \\
0.0589 \\
0.0033 \\
0.0934\end{array}$ & $\begin{array}{l}0.1080 \\
0.1353 \\
0.0796 \\
0.1559\end{array}$ & $\begin{array}{l}0.2142 \\
0.1973 \\
0.0982 \\
0.1864\end{array}$ & $\begin{array}{l}0.3132 \\
0.2173 \\
0.2080 \\
0.2293\end{array}$ & $\begin{array}{l}0.3387 \\
0.2031 \\
0.2537 \\
0.2883\end{array}$ & $\begin{array}{l}0.3933 \\
0.1536 \\
0.3502 \\
0.2627\end{array}$ & $\begin{array}{l}0.3576 \\
0.1147 \\
0.4755 \\
0.2733\end{array}$ \\
\hline $\begin{array}{l}\text { Miscellaneous chemicals, } 352 \\
\text { Rubber products, } 355 \\
\text { Plastics, } 356 \\
\text { Nonmetallic mineral products, } 369\end{array}$ & $\begin{array}{l}0.1543 \\
0.1876 \\
0.3562 \\
0.1472\end{array}$ & $\begin{array}{l}0.0448 \\
0.0537 \\
0.1124 \\
0.1251\end{array}$ & $\begin{array}{l}0.1005 \\
0.0641 \\
0.2067 \\
0.1321\end{array}$ & $\begin{array}{r}0.1464 \\
0.1421 \\
0.1766 \\
-0.0140\end{array}$ & $\begin{array}{l}0.1635 \\
0.1844 \\
0.3512 \\
0.1454\end{array}$ & $\begin{array}{l}0.1887 \\
0.2718 \\
0.5229 \\
0.1756\end{array}$ & $\begin{array}{l}0.2310 \\
0.3382 \\
0.7275 \\
0.2913\end{array}$ & $\begin{array}{l}0.3341 \\
0.4921 \\
1.1180 \\
0.2990\end{array}$ \\
\hline $\begin{array}{l}\text { Metal products, } 381 \\
\text { Nonelectric machinery, } 382 \\
\text { Electric machinery, } 383 \\
\text { Transportation equipment, } 384\end{array}$ & $\begin{array}{l}0.1646 \\
0.2581 \\
0.0828 \\
0.2863\end{array}$ & $\begin{array}{l}0.0211 \\
0.0361 \\
0.0168 \\
0.0945\end{array}$ & $\begin{array}{l}0.1193 \\
0.1626 \\
0.0455 \\
0.1250\end{array}$ & $\begin{array}{l}0.1297 \\
0.2106 \\
0.0731 \\
0.2392\end{array}$ & $\begin{array}{l}0.1594 \\
0.2900 \\
0.1197 \\
0.2710\end{array}$ & $\begin{array}{l}0.2344 \\
0.3762 \\
0.1593 \\
0.3820\end{array}$ & $\begin{array}{l}0.2913 \\
0.6077 \\
0.1171 \\
0.4471\end{array}$ & $\begin{array}{l}0.4405 \\
0.8402 \\
0.0732 \\
0.4764\end{array}$ \\
\hline
\end{tabular}


Part B. Variances of differenced log-capital

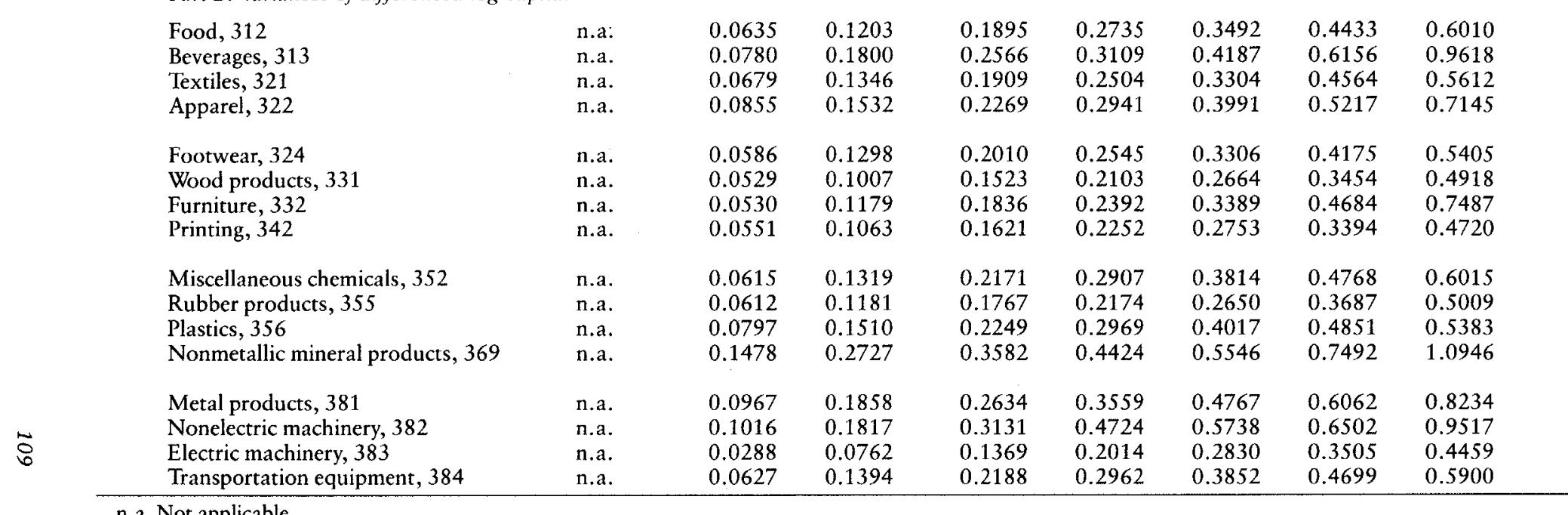

n.a. Not applicable.

Note: Estimates are based on balanced data; only plants that appear in all sample years are included, and industries with less than 20 such plants are not analyzed. Although not reported, time dummies are included in the regressions.

Source: Authors' calculations. 
residual variation in the projection of $d^{j} K$ on $d^{j} L$ and time dummies. Accordingly, the associated returns to scale estimator $\left(a_{j}+b_{j}\right)$ has asymptotic bias $(n \rightarrow$ $\infty, T$ fixed):

$$
\operatorname{plim}_{n \rightarrow \infty}\left[\left(a_{j}+b_{j}\right)-(\alpha+\beta)\right]=2\left(\gamma_{j}-1\right)\left(1-r_{j}\right) \beta \sigma_{\nu}^{2} / \operatorname{var}\left(d K_{p}\right) .
$$

Notice that the bias is negative so long as $\gamma_{j}<1$, and its absolute magnitude depends directly on the noise-to-signal ratio, $2\left(1-r_{j}\right) \sigma_{\nu}^{2} / \operatorname{var}\left(d i K_{p}\right)$. Also note that, on average, elimination of measurement error bias should typically reduce the estimated $\alpha$ value, increase the estimated $\beta$ value, and increase estimated returns to scale.

In the text we argue that measurement error bias is likely to fall as the length of the difference increases. One reason is that correlations between labor and capital $\left(\gamma_{j}\right)$ are stronger in the long run. This is confirmed for most industries by table A-1, part A. A second reason is that the signal-to-noise ratio in differenced capital stocks, $2\left(1-r_{j}\right) \sigma_{\nu}^{2} / \operatorname{var}\left(d i K_{p}\right)$, is likely to improve. This occurs if $r_{j}$ is bounded from below as $j \rightarrow \infty$ (for example, at zero), but $\operatorname{var}\left(d^{i} K_{p}\right)$ grows without bound. (Many stochastic processes for $K$ exhibit this property-a random walk is one example.) For evidence that $\operatorname{var}\left(d K_{p}\right)$ grows continuously with $j$ in our sample, refer to part B of table A-1. Of course, for small $j$ values, $r_{j}$ is also likely to fall with $j$, so the relation between $j$ and signal-to-noise ratios may not be monotonic in the lower range of $j$ values. Estimates of $r_{j}$ cannot be constructed with the available information.

\section{REFERENCES}

The word "processed" describes informally reproduced works that may not be commonly available through libraries.

Arellano, Manuel, and Stephen Bond. 1988. "Some Tests of Specification for Panel Data: Monte Carlo Evidence and an Application to Employment Equations." Institute for Fiscal Studies Working Paper W88/4.

Benhabib, Jess, and Boyan Jovanovic. 1991. "Externalities and Growth Accounting." American Economic Review 81 (March): 82-113.

Berry, R. Albert. 1992. "Firm or Plant Size in the Analysis of Trade and Development." In Gerald K. Helleiner, ed., Trade Policy, Industrialization, and Development: New Perspectives, Oxford: Clarendon Press.

Bhagwati, Jagdish. 1988. "Export-Promoting Trade Strategy: Issues and Evidence." The World Bank Research Observer 3(1): 27-58.

Chamberlain, Gary. 1980. "Analysis of Covariance with Qualitative Data." Review of Economic Studies 47: 225-38.

Corbo, Vittorio, and Patricio Meller. 1979. "The Translog Production Function: Some Evidence from Establishment Data." Journal of Econometrics 10: 193-99.

Demsetz, Harold. 1973. "Industry Structure, Market Rivalry, and Public Policy." Journal of Law and Economics 16: 1-10. 
Ericson, Richard, and Ariel Pakes. 1987. "An Alternative Theory of Firm Dynamics." Columbia University, New York, N.Y. Processed.

Griliches, Zvi, and Jerry Hausman. 1986. "Errors in Variables in Panel Data." Journal of Econometrics 31 (February): 93-118.

Griliches, Zvi, and Jacques Mairesse. 1988. Heterogeneity in Panel Data: Are There Stable Production Functions? NBER Working Paper 2619. Cambridge, Mass.: National Bureau of Economic Research.

Griliches, Zvi, and Vidar Ringstad. 1971. Economies of Scale and the Form of the Production Function. Amsterdam: North-Holland.

Heckman, James. 1979. "Sample Selection Bias as Specification Error." Econometrica 47 (November): 147-61.

Holtz-Eakin, Douglas, Whitney Newey, and Harvey Rosen. 1988. "Estimating Vector Autoregressions with Panel Data." Econometrica 56: 1371-96.

Jovanovic, Boyan. 1982. "Selection and the Evolution of Industry." Econometrica 50 (May): 649-70.

Jovanovic, Boyan, and Saul Lach. 1989. "Entry, Exit, and Diffusion with Learning by Doing." American Economic Review 79 (September): 690-99.

Liu, Lili. 1990. "The Chilean Data Base." World Bank, Country Economics Department, Trade Policy Division, Washington, D.C. Processed.

- 1991. "Entry-Exit, Learning, and Productivity Change: Evidence from Chile." PRE Working Paper 769. World Bank, Country Economics Department, Washington, D.C. Processed.

Marschak, Jacob, and W. H. Andrews. 1944. "Random Simultaneous Equations and the Theory of Production." Econometrica 12: 649-70.

Meller, Patricio. 1975. "Production Functions for Industrial Establishments of Different Sizes: The Chilean Case." Annals of Economic and Social Measurement 4(4): $595-$ 633.

Olley, G. Steven, and Ariel Pakes. 1992. "The Dynamics of Productivity in the Telecommunications Equipment Industry." Discussion Paper ces 92-2. U.S. Department of Commerce, Bureau of the Census, Washington, D.C.

Pakes, Ariel, and Paul McGuire. 1992. "Computing Markov Perfect Nash Equilibria: Numerical Implications of a Dynamic Model." NBer Technical Working Paper 119. National Bureau of Economic Research, Cambridge, Mass. Processed.

Pratten, Clifford. 1988. "A Survey of the Economies of Scale." In Research on the "Cost" of Non-Europe, vol. 2, Basic Findings. Brussels: Commission of the European Communities.

Rodrik, Dani. 1988. "Imperfect Competition, Scale Economies, and Trade Policy in Developing Countries." In Robert E. Baldwin, ed., Trade Policy Issues and Empirical Analysis. Chicago: University of Chicago Press for the National Bureau of Economic Research.

Scherer, Frederic, and David Ross. 1990. Industrial Market Structure and Economic Performance, 3rd ed. Boston: Houghton Mifflin.

Stigler, George. 1958. "The Economies of Scale." Journal of Law and Economics 54-71.

Tybout, James. 1992. "Making Noisy Data Sing: Estimating Production Technologies in Developing Countries." Journal of Econometrics 53: 25-44. 
Tybout, James, Jaime de Melo, and Vittorio Corbo. 1991. "The Effects of Trade Reforms on Scale and Technical Efficiency: New Evidence from Chile." Journal of International Economics 31 (November): 231-50.

Tybout, James, and M. D. Westbrook. 1992. "Trade Liberalization and the Structure of Production in Mexican Manufacturing Industries." Working Paper 92-03. Georgetown University, Department of Economics, Washington, D.C. Processed.

White, Halbert. 1982. "Instrumental Variables Regression with Independent Observations." Econometrica 50(2): 483-99. 


\title{
Theoretical Implications of Imperfect Competition on Quota License Prices and Auctions
}

\author{
Kala Krishna
}

This article looks at the implications for trade policy of recent work on quota auctions. Recent work has considered a variety of market structures in addition to the standard one of monopoly in the product market. It has also emphasized details of the implementation process, as well as the timing of decisions and dynamic factors. Such considerations are shown to be important, because they can greatly affect the outcome of trade policies.

It is well known that prices of quota licenses should not be interpreted as tariff equivalents when markets are imperfectly competitive (Bhagwati 1965; McCulloch 1973). The early literature on this topic, however, focused mainly on the equivalence issue, with imperfect competition simply modeled in the form of a monopoly. More recent work on trade policy with imperfect competition has taken a more explicitly game-theoretic approach. It has emphasized the importance of market conditions, market structure, and details of the quota implementation. Even within the perfect competition paradigm, new insights have been provided with the use of well-structured microeconomic models that take into account such factors as uncertainty and intertemporal considerations.

There has recently been renewed interest in the study of quantitative restrictions, especially auction quotas, and in various kinds of quota reform. Voluntary export restraints (VERs) have proliferated as a means of sidestepping the General Agreement on Tariffs and Trade, which explicitly forbids quotas. For example, developing countries today face significant quantitative restrictions on yarn, textiles, and apparel under the Multi-Fibre Arrangement (MFA), a system of bilateral, commodity-specific, quantitative restraints. Reform of the MFA is an important component of the ongoing Uruguay Round, and current proposals are to extend the MFA for one or two more years while a phaseout is negotiated.

Kala Krishna is with the Fletcher School of Law and Diplomacy at Tufts University and the National Bureau of Economic Research. The author is grateful to Phillip Swagel, Ling Hui Tan, and Kerstin Berglof for research assistance. Research for this article was conducted under a McNamara fellowship and was funded by grants from the World Bank and the National Science Foundation under Grant No. SES-8822204.

(C) 1993 The International Bank for Reconstruction and Development / THE WORLD BANK 
VERS are simply quotas that have been negotiated "voluntarily" between the exporting and importing country. Such quotas result in excess demand in the importing country at the world price. This situation creates scarcity rents for the restricted imported good. The allocation of these scarcity rents depends on how the quota is implemented. Usually, implementation is done by means of licenses that confer the right to import (to an importing firm), or the right to export (to an exporting firm), or the right to buy the restricted good (to a consumer in the importing country).

VERS are often justified by the importing country on the grounds that the rents resulting from the quota are appropriated by the exporting country, making the policy more acceptable to them. Import quotas could bestow the windfall gains to the importing country. The basic idea is illustrated in figure 1 . The importing country has an excess demand curve (demand less domestic supply) denoted by $D(P)$. The exporting country, which we can think of as the rest of the world, has an excess supply curve (the excess of supply over demand) denoted by $S(P)$. Under free trade, quantity $Q^{F}$ is imported at price $P^{F}$. If an import quota is imposed of amount $V$, which is below the free trade level of imports, the rest of the world is willing to supply the amount $V$ at price $P S(V)$, while domestic consumers are willing to pay $P^{D}(V)$ for this amount. The difference between the two prices is the value of an import quota license, $L(V)$. The same amount $(V)$ could also be imported, with the outcome unchanged, by imposing a specific tariff of $L(V)$. The tariff would raise the supply curve in figure 1 so that it would intersect the demand curve at $V$. This is the argument showing the equivalence of a tariff and an import quota under competition.

Auctioning the import quota licenses generates $L(V) V$ revenue. These rents would accrue to the party that sells the licenses or to the party or parties to whom the licenses are awarded. When a VER is in place, the presumption is that agents in the exporting country obtain the rents: if the licenses are sold, then the quota rent would go to the authority in the exporting country responsible for their sale. By contrast, if the licenses are allocated to exporting firms, the quota rent would go to those firms.

Both in industrial and in developing countries, there has been great interest in auctioning quota licenses. This interest stems from the perceived benefits of such a policy. First, because most existing quotas are allocated to the exporting country, the importing country does not receive the quota rents. Auctioning quotas by the importing country is seen as one way it can retrieve these rents. Many proponents of auctioning quotas in the United States focus on their revenue-raising potential. For example, Tarr $(1989$, p. 98), using a general equilibrium model, estimates that quota rents accruing to restricted exporters of textiles, automobiles, and steel to the United States were about $\$ 14$ billion in 1984. Because product markets are imperfectly competitive in the automobile and steel industries, however, estimates based on models of perfect competition may well exaggerate the revenue-raising potential of quota auctions.

The second perceived advantage of auctioning quotas is that if actual license 
Figure 1. Effect of a Quota under Perfect Competition

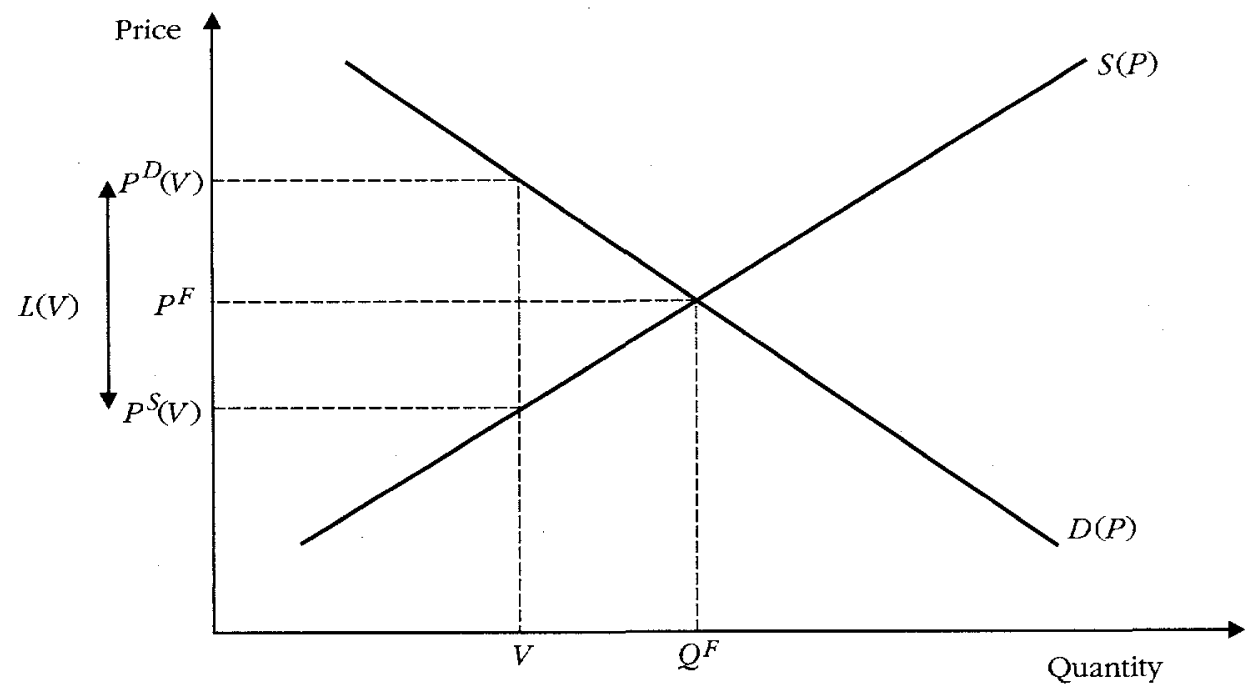

prices can be used to convert quotas into tariffs, the tariffs can then be phased out in a liberalization process. It is not easy to calculate the tariff equivalents of quotas. A number of countries, including Australia, New Zealand, and Colombia, have actually implemented quota auctions, used the license prices to switch over to tariffs, and then phased out the tariffs. Takacs (1990) provides a detailed account of how license prices from quota auctions are used in trade liberalization. This use of license prices is questionable, however, because market imperfections, the quota implementation procedure, and dynamic elements create nonequivalence between tariffs and quotas.

Sometimes license prices in one exporting country are used to impute unavailable license prices in another exporting country (see Hamilton 1986 and Trela and Whalley 1991 on the MFA). Trela and Whalley compute the Hong Kong supply price by subtracting the license price from the U.S. price. They then compute the production costs of quota-restricted products in other exporting countries by multiplying the unit cost in Hong Kong with the ratio of the exporting country's relative wage in the textile and apparel industry compared with that of Hong Kong's. The license price in the exporting country then can be imputed as the difference in this production cost and the U.S. price. This calculation results in large estimates of the rents retained in several exporting countries, with consequent implications for reform of the MFA. These estimates may not be very meaningful, however, if they are different from the actual license prices. Such differences could occur, for example, if countries have different quota implementation procedures, affecting their ability to retain the rents from 
export quotas. Krishna, Martin, and Tan (1992) show that this procedure does indeed seem to provide overestimates of the actual license prices.

The analysis of the basic model of auctioning import quota licenses is certainly correct, given its assumptions. But the assumptions themselves may be inappropriate for at least three reasons. The first is the existence of market power. The second is that the basic model illustrated in figure 1 does not address details of the quota implementation procedure. The third is that the model is static and assumes no uncertainty. The limitations of the basic model have important consequences for policy.

This article is organized as follows. Section I discusses the implications of market imperfections in both the product and the license markets. Section II highlights the importance of studying how the quotas are implemented. Section III introduces uncertainty and dynamic elements to the basic competitive model. Section IV contains some concluding remarks.

\section{MARket Power}

In analyzing the effects of a quota, and quota license auctions, two distinct but related markets are involved: the market for the product and the market for the licenses. For example, under perfect competition, the size of the quota affects the supply price, $P^{S}(V)$, in the product market. The quota also determines the supply in the license market. But demand for the license is based on the price charged for the good in the product market. Demand and supply together determine the value of the license. In each market, there may be market power on the buyer's side, on the seller's side, or on both sides. Much of the existing literature has focused on market power on the seller's side in the product market. But even if there are a large number of perfectly competitive sellers on the supply side of the product market, there may be market power on the buyer's side. For example, in apparel trade under the MFA, there are often claims that large retail stores in the United States exert monopsony power (see Goto 1989, p. 128, and Caves and Rosen 1982, p. 16).

Furthermore, even if the product market is competitive, the license market may not be. If license allocations are determined on the basis of historical market share, concentration in license holdings could be a consequence of history. For example, concentration in license holdings varies quite considerably across apparel categories in Hong Kong. The Herfindahl index of licenseholding concentration gives an estimate of the number of firms of equal size in the market. In considering trade between the United States and Hong Kong under the MFA, the index varies from around 70 for cotton dresses and knit shirts of man-made fiber to around 4 or 5 for men's cotton woven shirts and men's wool jackets. An editorial in the Hong Kong trade journal Textile Asia, in March 1989, alleges that "quota price fluctuations do not in fact reflect normal supply and demand but the course of manipulation by quota holders."

If producers are perfectly competitive but there is market power in the license market and on the part of the buyers, then the license price may fall short of the 
potential rent. This is termed rent sharing. Krishna, Erzan, and Tan (1991) provide evidence to suggest that rent sharing exists in the MFA, and hence the effects of any proposed reforms to the MFA are likely to be very different from those predicted on the basis of competitive models.

To adequately assess the effects of a quota, both the product and license markets need to be considered. A quota affects the shape of the perceived demand curve facing firms with market power and hence affects the behavior of the firms. The details of the argument vary, depending on the kind of competition facing producers, that is, whether power is in the domestic or foreign market or in both, as well as on demand conditions. For example, if there is imperfect competition in the product market at home or abroad or both, there is no supply curve, because output is chosen to maximize profits, and the choice of output depends on demand conditions. Moreover, because the response of producers in choosing price is very different under a quota than a tariff, the results of a tariff policy with imperfect competition, as developed in Brander and Spencer (1985) and Eaton and Grossman (1986), do not apply.

\section{Domestic Product Market Power}

Throughout the discussion of the product market, I assume that license markets are perfectly competitive and that licenses are sold either to competitive retailers with zero marginal costs or to consumers directly. A license entitles its possessor (a retailer or consumer) to buy one unit of the product in question at the price charged by the seller (producer). There are only two countries in the world: Home and Foreign.

If there is no market segmentation, arbitrage enables the license holder to buy at the lower of the prices charged by the seller in the Home and the Foreign market. If the seller attempts to charge a different price in each market, however, consumers will simply buy at the lower of the two prices. Thus, the seller can be restricted to choosing only one price without loss of generality when markets are not segmented.

I assume that the Home government first sets the quota for imports into the Home market. Then the producer sets the price of the product. Finally, the market for licenses clears. This timing structure is consistent with the idea that the market for licenses clears more frequently than the producer sets the product price and that the producer sets the product price more frequently than the government sets the quota. ${ }^{1}$ Note that because of this timing structure, the price charged by the producer and the quota level set by the Home government are both taken as given when the license market clears. The former affects the demand for licenses, and the latter determines the supply of licenses. Thus the equilibrium license price is determined for the given supply price and quota level. The producer takes the quota as given, but realizes that the choice of price

1. This assumption is not really needed; similar results obtain when the monopolist is able to adjust the product price faster than the rate at which the market for licenses clears (Krishna 1990a). 
will affect the value of a license in the license market. The government, being the first mover, realizes that its choice of the quota level will affect the price chosen by the producer and the value of a license.

The model is then solved backward. First, the market for licenses clears, then the producers with market power set the price, taking into account the effect on the license price. Finally, in determining optimal policy, the government chooses the quota, taking into account its effect on the producer's choice of product price and the equilibrium license price.

Domestic monopoly. The standard case of Home monopoly and Foreign competitive supply has been widely analyzed (Bhagwati 1965; Shibata 1968). In this case, the supply price from abroad is fixed by the quota level, but the output and price chosen by the domestic producer is affected by the quota because of monopoly power at Home. The license price is positive if, and only if, the supply price from abroad is lower than the demand price. (The demand price is the price at which domestic demand equals the supply from abroad plus domestic production.) The difference between the supply price from abroad and the demand price is the license price.

Under free trade, the domestic monopolist faces the residual demand curve (domestic demand less foreign supply) and chooses price to maximize profits. The domestic monopolist's choice of price then elicits a level of supply from abroad. When the Home and Foreign goods are substitutes, a quota at the free trade level does not affect the Home monopolist's demand curve below the free trade price, because at this price the quota is not binding. The quota causes demand to be less elastic for price increases above the free trade level, however, because raising the price makes the quota bind on the foreign suppliers. In figure $2, A B$ is the residual demand curve without a quota. If a quota is set that elicits this supply from abroad at price $P$, the demand curve with a quota is given by $C E B$, where $C D$ is a steeper curve than $A B$. This creates an incentive for the Home monopolist to raise the price, which causes a divergence between the demand price and the supply price from abroad and creates a positive price for import licenses. Thus, the license price exceeds the free trade tariff of zero. By continuity arguments, for quotas near the free trade level, the license price will exceed the tariff that leads to the given import level.

Note that with substitute goods and a domestic monopoly, the imposition of any quota can only raise the domestic price. Domestic production could rise or fall. It falls if the quota is close to free trade levels, but can rise if it is more restrictive. Furthermore, the quota need not be more restrictive than free trade to have an effect. A quota at the free trade level will raise the price and reduce domestic production.

If the Home and Foreign goods are complements, a quota at the free trade level makes the Home monopolist's demand curve less elastic for price decreases below the free trade price, but leaves it unaffected for price increases above the free trade price. This makes it unprofitable for the Home monopolist to either raise or lower the price from the free trade level. Therefore, the market for 
Figure 2. Effect of a Quota on Home Demand in the Presence of Imperfect Competition

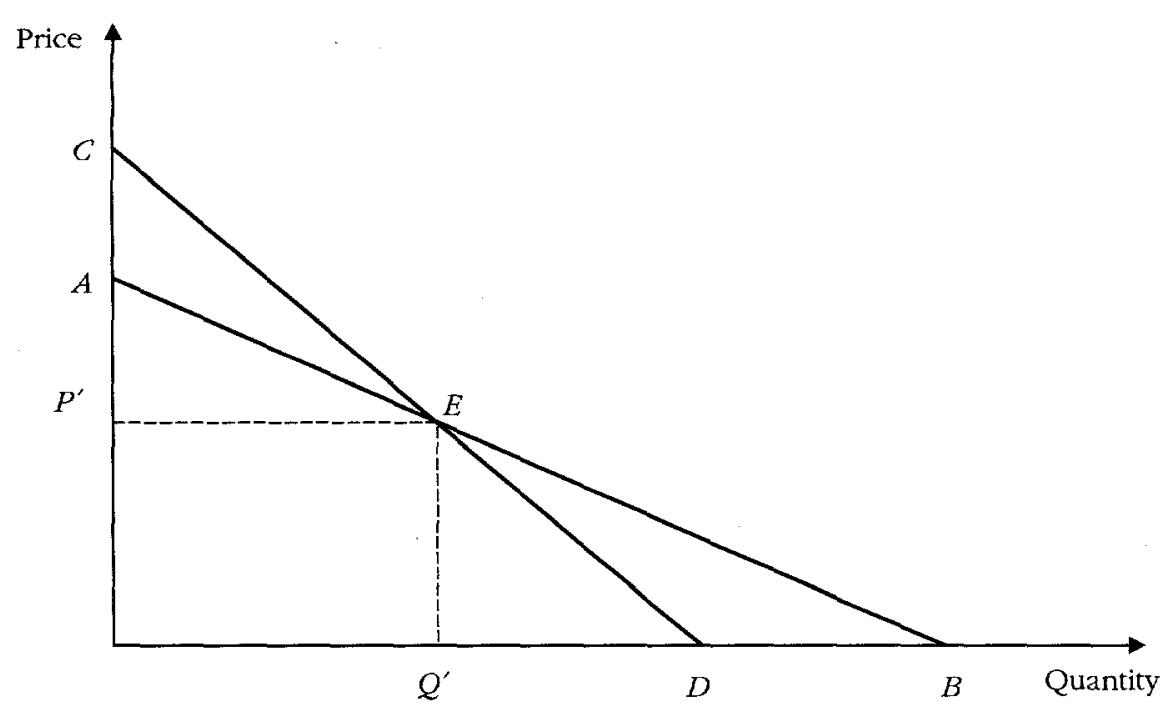

licenses clears at the license price of zero. If the quota is set below, but close to, the free trade level of imports, the price of the domestic good at which the quota on imports becomes binding-call it $P^{+}$-exceeds the free trade price. At prices below this level, the quota on imports binds and, because the goods are complements, the quota reduces the demand for the Home monopolist's product. Hence the Home monopolist's demand curve is kinked at $P^{+}$, being more inelastic for price decreases than for price increases. These considerations tend to cause the Home monopolist to set the price at a point at which the quota is just binding on imports. This in turn means that the license price is zero, although the tariff that gives the same level of imports is positive. In this case, therefore, the tariff tends to exceed the license price (see Krishna 1989b).

Domestic oligopoly. Similar results obtain when the domestic firm has a few competitors who are also unrestricted by a quota and who have market power. Consider a market in which differentiated products are sold. There are two symmetric Home firms (Firm 1 and Firm 2) with market power that are not subject to a quota. ${ }^{2}$ For ease of exposition, let $P^{1}$ and $P^{2}$ denote their prices and let $P^{*}$ be the price of the competitive Foreign firms who make a homogeneous product and who are restricted by a quota. Assume that all firms have an identical constant marginal cost of production. Because the Foreign firms are competitive, $P^{*}$ is equal to this marginal cost, and supply from the Foreign firms

2. Alternatively, they could be two other Foreign firms that are not subject to the quota. An example of such a country-specific quota is the VER on automobiles in 1981 that was aimed at Japan. 
is infinitely elastic at this price. The Home firms make products that differ from each other and from the goods produced by the Foreign firms. In the absence of any quotas, each Home firm maximizes its profit by choosing its price, taking its rival's price (and the foreign price) as given.

Now consider the effects of a quota on imports at the free trade level. When imports and domestic goods are substitutes, license demand is based on the demand for imports. If the price of a license is $L$, demand for a license is given by $D^{*}\left(P^{1}, P^{2}, P^{*}+L\right)$, where $D^{*}($.$) denotes the demand for imports. The supply of$ licenses is at most equal to the quota level, $V$. The equilibrium level of $L$ is determined by setting the demand for licenses equal to the supply. If the demand at a zero license price exceeds $V$, the license price is zero; otherwise, it is positive. Thus, the license price is increasing in $P^{1}$ and $P^{2}$, but decreasing in the quota level. Raising the price of import substitutes shifts the demand for licenses outward, thereby raising the license price. Raising the quota level shifts the supply of licenses outward, reducing the license price.

The presence of a quantitative constraint on imports makes the demand facing each Home firm, at the point where the quota just binds, less elastic for price increases, but unaffected for price decreases. The domestic firms recognize that demand for their goods depends on the full price of imports, $P^{\prime \prime}+L($.$) . With a$ quota, when domestic firms raise their price, the price of licenses is also raised. The domestic firms therefore lose fewer customers to foreign suppliers than they would without a quota. In figure $2, A B$ is the demand curve facing a Home firm when its rival Home firm charges the free trade price. The quota transforms the perceived demand curve to $C E B$. Each Home firm thus has an incentive to raise its price, given the price set by the other firm. If they do so, they raise the equilibrium domestic price and consequently induce an increase in the demand for imports. This increase in demand in turn creates a positive price for a license to import, even when the quota is set at the free trade level. The price-raising incentive is discussed in Bhagwati (1965) for the case of a domestic monopoly and in Helpman and Krugman (1989) for the general case of market power at home.

Selling licenses raises revenue, but it may not lead to an improvement in the Home country's welfare. Because Foreign supply is competitive, the quota system does not shift profits. The gain in revenue comes at the expense of consumer surplus. A quota thus results in a deadweight loss, despite the positive license price and revenue thereby derived. This result is true for quotas both above and below the free trade level.

When imports and Home goods are complements and the quota is set at the free trade level, the price of a license is again implicitly defined as a function of $P^{1}, P^{2}$, and the quota level. In this case, however, the license price is decreasing in all three arguments. The quota binds only if the Home firms charge a low price. But the binding quota raises the full price of the import and, because the goods are complements, causes the Home firms to lose sales. Thus, demand facing a Home firm is given by a curve like $A E D$ if $A B$ is the unrestricted demand 
curve, and $P^{\prime}$ is the price where the quota just binds. Hence, there is no incentive for either Home firm to cut its price. The free trade equilibrium remains an equilibrium, and the license price is zero. Quotas close to, but below, the free trade level lead to many possible equilibria, all of which have a license price of zero. Quotas above the free trade level have no effect.

\section{Foreign Product Market Power}

Market power may take the form of a monopoly or oligopoly in Foreign supply, with Home production, if any, being competitive. The implications for the license price would be different from those under domestic product market power.

Foreign monopoly. If there is a single Foreign supplier of the product and the Home and Foreign markets are segmented, it is clearly optimal for the Foreign monopolist to raise the price in response to a quota so that the price of a license becomes zero. A positive license price would indicate that consumers are willing to pay more than the price the monopolist is charging. And raising the price will not reduce sales, because the monopolist is constrained by the quota. In terms of figure 2, the quota makes the demand curve totally inelastic for price decreases so that it is given by $A E Q^{\prime}$ after the quota, and $A B$ before it. This model with segmented markets is developed diagrammatically in Bergsten and others (1987) and is also mentioned in Shibata (1968) and in Helpman and Krugman (1989).

Now suppose there is costless arbitrage between the Home and Foreign markets so the Foreign monopolist cannot practice price discrimination. One would then expect the Foreign monopolist to limit the price increase in response to a quota, thereby creating a price for the license. Somewhat surprisingly, this is not necessarily so. Quotas set close to the free trade level always have a price of zero.

The intuition behind this result is apparent when we consider the effect of the quota on the Foreign monopolist's demand and profit functions. Let $P^{\prime}$ denote the price at which the Foreign monopolist's demand from the Home market exactly equals the quota level. ${ }^{3}$ If the Foreign monopolist sets prices above $P^{\prime}$, total demand for the Foreign good is unaffected, because the quota does not bind. If the Foreign monopolist sets prices below $P$ ', the quota constrains total demand in the Home market. Thus, in figure 2, the perceived demand curve with a quota is transformed from $A B$ to $A E D$. The quota makes demand less elastic for price decreases below $P^{\prime}$, creating incentives to price at the kink at $P^{\prime}$. At $P^{\prime}$, however, by definition the value of a license is zero.

The Foreign monopolist's profits are unaffected by the quota if prices are set above $P$, because the quota does not bind. At prices below $P^{\prime}$, however, profits are constrained by the existence of the quota. At prices below $P^{\prime}$, the Foreign monopolist's profits equal unrestricted profits from both markets minus the loss

3. $P^{\prime}$ depends on the quota level. As the quota increases, $P^{\prime}$ falls. 
imposed by the quota in the Home market. If the quota is set at or below free trade, the Foreign monopolist's profit decreases at prices above $P^{\prime}$. The free trade monopoly price lies below $P^{\prime}$, and it is assumed that the profit function is concave in price.

Pricing below $P^{\prime}$ has two effects on profits: the effect on unrestricted profits from both markets and the effect on the loss from the quota imposed by the Home country. If the quota is close to the free trade level, the first effect is close to zero at $P^{\prime}$, because $P^{\prime}$ is close to the free trade price, where this effect equals zero. Raising the price to $P^{\prime}$, however, reduces the loss from the quota. Essentially, by raising the supply price, the monopolist can appropriate the quota rents and, in fact, will choose to do so, because if the quota is not too restrictive, there is little loss in profits. Note that a quota reduces Home welfare if it generates no revenue and restricts consumption, which is already too low because of the presence of monopoly power (Krishna 1990a). If the quota is very restrictive, however, it may be profitable for the monopolist to set the price below $P^{\prime}$ and allow a positive license price. In either case, the license price does not reflect the equivalent tariff.

How do the sizes of the two markets and their relative elasticities affect the monopolist's incentive to raise the supply price and reduce the value of a license? If demand elasticities in the two markets are the same, the incentive to raise the price in order to appropriate quota rents is weakened as the size of the Foreign market rises. This weakening is reflected in the license price becoming positive relatively fast as the quota falls. The intuition is that raising the supply price in response to a quota becomes increasingly costly in terms of profits foregone in the Foreign market as the size of the Foreign market grows.

If the elasticity of demand is the same in the two markets, welfare can never rise, even if the quota is set optimally. But if Foreign demand is more elastic than Home demand, it is possible for welfare to rise when the optimal quota is set. In this case, raising the price to make the quota bind will cost the monopolist dearly, because the monopolist will lose customers in the Foreign market. Hence the Foreign monopolist will moderate price increases and will not appropriate all the quota rents in the Home market. This effect is strongest if the Home market is small in relation to the Foreign market. Thus, the size of the country imposing and auctioning a quota and its demand elasticity in relation to the rest of the world are likely to be important in determining the effects of such a policy.

Foreign oligopoly. If there are many Foreign firms and competition among them is strong enough, one would expect that the price would not rise in response to a quota and that the price of a license could be positive. Oddly enough, even the pressures of competition may not outweigh the firms' incentive to raise prices to obtain license rents. This can be shown in a simple static oligopoly model of price competition with differentiated products. The assumption of price competition is made both for convenience and because price competition is more intense than quantity competition when goods are substitutes 
(Eaton and Grossman 1986). I abstract from a Foreign market in this section in order to focus on the rivalry between the Foreign producers in the Home market.

Suppose there are many Foreign firms facing a global quota in the Home market. Each firm will be discouraged from raising its price in response to the quota, because doing so would reduce its own sales and boost its competitors' sales. Even in this case, licenses have a price of zero, unless the quota is quite restrictive, because the effect of competition among firms does not outweigh each firm's incentive to strategically affect the price of a license.

Consider a model of a Foreign duopoly. Home supply can be incorporated (as long as it is competitive) by reinterpreting Foreign demand as residual demand, given competitive pricing by Home firms. For simplicity, assume that the two Foreign firms (Firm 1 and Firm 2) are identical (that is, impose symmetry). Further assume that Firm 1 and Firm 2 face identical constant marginal costs and produce goods that are substitutes for each other.

In the absence of any quotas, each firm maximizes its profit, taking its rival's price as given. With a global quota, the demand for licenses equals the sum of the demand for the goods produced by the two firms when the prices entering the demand functions include the license prices. The supply equals the quota level. The license price falls as the price charged by a firm rises, because increasing the product price shifts the demand for licenses inward. In addition, it will be assumed that own effects dominate cross effects so that a given increase in the price of both firms reduces demand.

The free trade equilibrium remains the equilibrium when the quota is set at the free trade level. This, of course, implies that the license price is zero in equilibrium. To see why this occurs, suppose the free trade price level for Firm 1 is $P^{1 F}$ and the free trade price level for Firm 2 is $P^{2 F}$. If Firm 2 sets its price at $P^{2 F}$ and Firm 1 sets its price below $P^{1 F}$, the quota becomes binding and the price reduction has the additional effect of raising the license price. The full price (including the license price) of both goods will increase by the same amount. The induced increase in the full price restricts the demand for each good and causes the demand curve with a quota to lie inside the unrestricted demand curve for price decreases. Thus Firm 1 has no incentive to set its price below $P^{1 F}$. And, because $P^{1 F}$ was profit-maximizing in the absence of a quota, Firm 1 has no incentive to raise its price above $P^{1 F}$. Similarly, Firm 2 has no incentive to change its price from $P^{2 F}$. Hence, the free trade prices constitute a Nash equilibrium after the imposition of a quota at the free trade level.

Now consider the effect of a quota that is very slightly below the free trade level. The quota causes demand to be less elastic for prices below the price at which the quota just binds; the quota does not affect the elasticity of demand at prices above the quota-binding level. The optimal price is the price at which the quota just binds. Therefore, in this case, licenses have no value in equilibrium.

If the quota is quite restrictive, reducing it further will result in the sale of licenses and positive revenue. The resulting improvement in welfare may be 
offset by the loss in consumer surplus. Helpman and Krugman (1989), in studying the effects of a VER or quota with a Foreign duopoly, use a linear specification to show that it is never optimal to set a restrictive quota. Krishna (1992) provides an example showing that the license price becomes positive faster as the number of Foreign firms rises and as their products become more substitutable. This makes sense, because both of these effects make the market more competitive. A general result of this example is that welfare declines when a quota is imposed. To increase welfare, the price charged by the Foreign firms would have to fall below the free trade price; consumer surplus losses could then be made up by revenues from quota licenses.

With Foreign market power, auction quotas that do not raise revenue must reduce domestic welfare, because the quotas further restrict consumption without shifting profits. ${ }^{4}$ Welfare worsens as the quota is reduced from the free trade level of imports to the level where licenses begin to have a price that is not zero; welfare rises only after the price of licenses becomes positive. Therefore, even optimally set auction quotas are unlikely to improve domestic welfare.

\section{Product Market Power at Home and Abroad}

It is apparent from the preceding sections that the implications of imperfect competition for license prices depend on whether the market power is domestic or foreign. If there is market power on both sides, some technical problems arise. With two-sided market power, both Home and Foreign firms have incentives to raise their prices. The license price will again fall below that suggested by intuition based on competitive models.

Let us consider a model with one Home firm and one Foreign firm producing substitute goods. The Home firm, by raising its price, can increase the demand for the Foreign product, thereby making the quota bind. When the quota is binding on the Foreign firm, however, the Home firm's demand becomes less elastic, which makes it in the Home firm's interest to raise its price. If the quota is binding on the Foreign firm, it is in the Foreign firm's interest to raise its price, too. Thus, both prices tend to rise, and quotas facilitate collusion.

Because a quota acts like a capacity constraint on the Foreign firm, there is no pure strategy equilibrium in this game. (See Krishna 1989a for a more detailed analysis.) The mixed strategy equilibrium involves the Home and Foreign firms charging prices such that demand for the Foreign firm exceeds the level of the constraint with a non-zero probability. In this event, a license is valuable; therefore, the price of a license is positive, even when the quota is set at the free trade level. As the quota shrinks, however, equilibrium prices change as well, and there is no reason for license prices on average to rise or fall.

When the Foreign and Home goods are complements, the Home firm has no

4. This is because of the assumption of Foreign competitive supply with constant marginal cost. In the absence of constant marginal costs, the Home country is likely to benefit from a favorable terms-of-trade effect resulting from the quota. 
incentive to make the constraint bind on the Foreign firm by charging a low price. A quantitative constraint on the Foreign firm thus leads to a pure strategy equilibrium, in which prices charged are such that the demand for the Foreign product exactly equals the level of the constraint. The price of a license will be zero, even when the constraint is set below the level of imports under free trade (Krishna 1989b).

\section{Market Power and Strategic Behavior in License Markets}

So far, I have assumed that quotas are sold directly to competitive retailers or to consumers and that license markets are competitive. When quotas are auctioned, there are usually provisions to prevent monopolization of licenses and to ensure that licenses are fully utilized. ${ }^{5}$ But is the assumption of competitive license markets appropriate? If exporters as well as retailers may buy licenses, is there a tendency for monopolization of the license market? What do actual prices paid for licenses mean? These questions are relatively difficult to handle using the standard models in the auction literature. The standard models exogenously specify the valuation or distribution of valuations of agents, whereas the license price is endogenously determined and depends on the allocation of licenses. Thus, significant complications are introduced at a formal level, and the form of the auction becomes crucial. Models of sequential auctions with endogenous valuations developed in Krishna (1990b and 1990c) provide a beginning here.

One might expect that a Foreign monopolist would tend to monopolize the license market, because the monopolist can internalize the effect of his or her own pricing decisions, whereas other buyers of licenses cannot do so. But Krishna (1990b) shows that in a sequential auction this does not occur unless all licenses are sold together as one unit, and retailers do not end up having market power in equilibrium because no retailer becomes large.

The intuition behind the result can be seen from the following example. Assume there are two licenses to be auctioned. There are two bidders: the Foreign monopolist and a competitive Home retailer. The monopolist would gain more than the retailer by obtaining both licenses, because the monopolist also sets the price of the product. Suppose that the Foreign monopolist assigns a value of 10 to having one license and a value of 20 to having both. The competitive Home retailer assigns a value of 9 to having one license and a value of 10 to having both. If both licenses are sold together, the Foreign monopolist will obtain them for a price of 10 . However, if they are sold one at a time, this is not so. To solve for the equilibrium outcome of this sequential game, it is necessary to work backward. This is most easily done by means of figure 3 , in which a tree depicting possible outcomes is drawn. Each license could go to either the Foreign monopolist or the competitive Home retailer. At every node, the left branch

5. The details of these procedures for Colombia, Australia, and New Zealand are documented in Takacs (1990). 
Figure 3. An Example of a Sequential Auction: The Outcome Tree

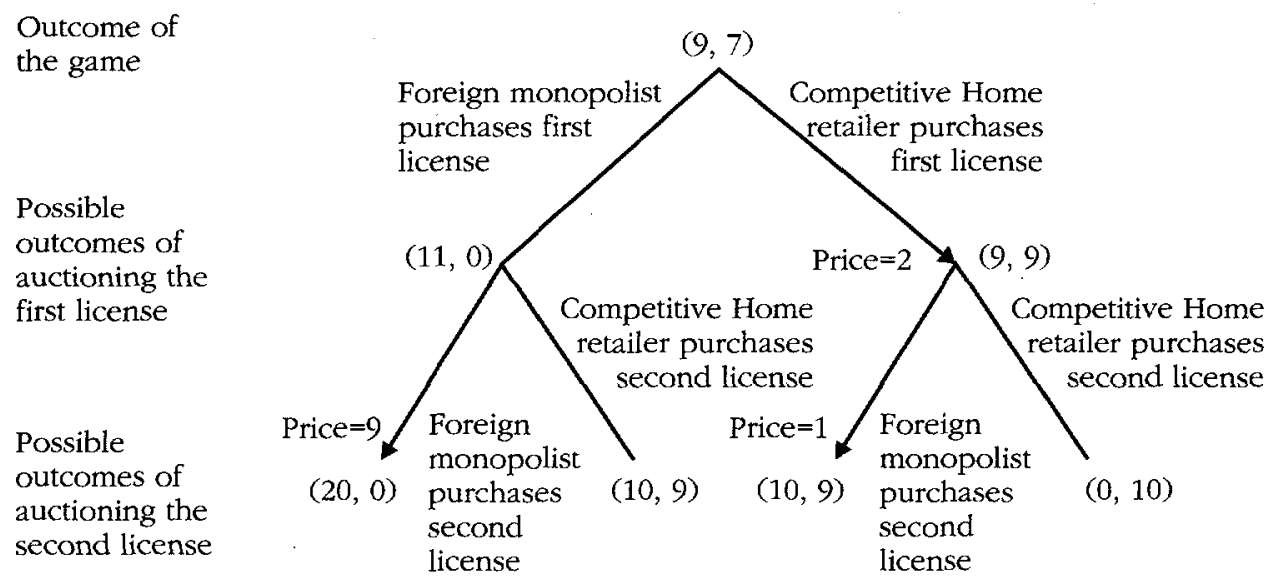

Note: In this example two licenses are auctioned sequentially to two bidders: the Foreign monopolist and the competitive Home retailer. The payoffs to the Foreign monopolist, $F$, and the competitive Home retailer, $H$, are shown by the numbers in parentheses as $(F, H)$

denotes that the license goes to the Foreign monopolist and the right branch that it goes to the competitive Home retailer. It is important to note that this outcome form is different from the usual extensive form depiction of a game. A complete extensive form description of the game is too complicated. The abbreviated outcome tree contains all the relevant information and is more useful.

The end points of the tree give the payoffs associated with each of the four possible outcomes. Arrows denote the allocation at each stage, and prices are given in brackets next to the paths. Consider the situation when the first license has gone to the Foreign monopolist. The Foreign monopolist is willing to pay 10 for the second license whereas for the competitive Home retailer it is worth only 9. Thus the Foreign monopolist would obtain the second license as well, paying a price of 9 . If the competitive Home retailer had the first license, again the second license would go to the Foreign monopolist, who would pay only 1 for it. How much is the Foreign monopolist willing to pay for the first license? To calculate this, the two nodes can be replaced by their equilibrium values. These are $(11,0)$ and $(9,9)$, respectively. The value to the Foreign monopolist of obtaining the first license is the difference between the values of the two nodes and thus equals 2 . Similarly, the value to the competitive Home retailer of obtaining the first license is 9. Thus the competitive Home retailer would get the first license at a price of 2 . The outcome of the game, therefore, is that the competitive Home retailer buys the first license at price 2 and the Foreign monopolist buys the second at price 1 . The Foreign monopolist's ex ante payoff is therefore $10-1=9$. The competitive Home retailer's ex ante payoff is $9-2$ 
$=7$. These numbers are shown in the vector at the top of the tree. Hence, it is shown that monopolization does not occur if the licenses are sold sequentially.

The monopolist always wins the last license because the monopolist's marginal valuation exceeds that of the retailer. But the first license goes to the retailer because the retailer's willingness to pay for the first license exceeds that of the monopolist. If the retailer wins the first license, the monopolist can win the second one for a low price of 1 . If the monopolist wins the first license, the price of the second license will be 9 ; therefore, the monopolist is better off letting the first license go to the retailer. Thus, even if the first agent's marginal valuation at the last stage lies everywhere above that of the second agent, the first agent does not necessarily obtain all the licenses. In addition, the price paid for the two licenses is different and need not equal the tariff equivalent.

Thus, the monopolist does not win all the licenses if they are auctioned sequentially. In fact, it turns out that the monopolist only wins the last license. The monopolist chooses not to win any earlier licenses, because doing so would raise the price for later licenses. Retailers remain small if we assume that there are a large number of potential retailers. Retailers who already have licenses will internalize the reduction in the value of licenses they already have, and will be outbid by new entrants. This keeps retailers small in equilibrium.

If license auctions are best modeled as auctions with endogenous valuations, we would not expect the implications of standard auction models to apply. Unfortunately, endogenous valuation models are both complex and poorly understood at this time. This being the case, empirical work on such models is still not possible. It is possible, however, to test the predictions of standard models for quota license auctions. If these models do not seem to perform well, the reason might be that valuations are endogenous and not exogenous. Even this has not been attempted so far.

\section{Monopsony Power and Rent Sharing}

One of the most difficult cases for economists to assess is the case where both buyer(s) and seller(s) have some degree of market power. In this situation, the relative bargaining strength of each party determines how existing rents are distributed. Models based on noncooperative bargaining (Rubinstein 1982) are relevant if there is market power on the part of the license holders together with market power on the part of the importers of the quota-constrained goods. In this case, the two parties have to bargain over the existing potential quota rent. The potential rent per unit is the difference between the demand price for the product in the importing country and the supply price in the exporting country. How the potential rent is split between the license holders and the importers depends on the relative bargaining power of the two sides. The license price is the result of such bargaining and need not equal the potential rent.

Referring again to figure 1 , in the competitive model, the license price changes with the quota level, $V$, so that $P D(V)=P S(V)+L(V)$ always. In other words, this equality is unaffected by changes in the quota level, and the license price, 
$L(V)$, is always equal to the potential rent, $\left[P^{D}(V)-P^{S}(V)\right]$. Now suppose there is competitive supply, but concentration in license holdings as well as market power on the buyer's side. If the potential rent, $L(V)$, is bargained over and shared in some way between the license holders and the importers, so that of $L(V)$, the license holders will get a fraction, $\alpha$, for $\alpha \epsilon(0,1)$ of these potential rents. In this case, the license-inclusive import price will lie somewhere between $P D(V)$ and $P S(V)$. Note that the license price is no longer equal to the potential rent. In addition, the license-inclusive import price can vary with the quota level, as well as the quota utilization ratio and the concentration in license holdings.

In general, there are many reasons why the license price may deviate from the potential rent. Krishna, Erzan, and Tan (1991) argue that bilateral power can lead to sharing the potential rents. To examine the evidence that potential rents are in fact shared, the authors use data on exports of apparel from Hong Kong to the United States under the MFA. If there is no rent sharing, the licenseinclusive Hong Kong price, adjusted for tariffs and transportation costs, should equal the U.S. price for the same commodity. Any deviation between the two prices that is not attributable to differences in quality or to data aggregation is taken to indicate rent sharing. The authors find that price differences exist even after accounting for differences in composition and quality. Moreover, these price differences are related to factors such as the quota level, the concentration of license holdings, and the quota utilization rate. Standard competitive models predict that such unexplained price differences should not exist and that any differences that do exist should be small (zero, on average) and uncorrelated with factors such as those mentioned above. This evidence suggests that competitive models may not be adequate for understanding the operation, effects, or proposed reforms of the MFA quotas.

\section{The Procedure for Implementing a Quota}

When market imperfections exist, the procedure for implementing a quota becomes especially important, and the simple model outlined above needs to be augmented. The procedure is important for two reasons. The first is that the procedure itself may create market power, enhance existing imperfections, or create new distortions. An obvious example of the creation of market power would be one in which the exporting country allocates the entire quota to one firm. If market power already exists, the procedure for implementing the quota can act as a facilitating practice. For example, in practice, licenses are often allocated to firms on the basis of market share. This practice could enhance the market power of some firms, because the firms would no longer be competing against each other in the quota-constrained market. And the procedure for implementation may itself create new distortions. For example, a procedure that involves much red tape and discretion on the part of a government agency could lead to a waste of resources as well as provide a fertile environment for graft and unproductive rent-seeking practices. 
Second, the procedure for implementing a quota affects the behavior of agents, because it can be used to achieve particular policy objectives. For example, a quota implemented by the sale of all licenses may not raise much revenue and may adversely affect welfare in relation to free trade. Alternative procedures for implementing a quota may improve welfare, even in relation to free trade. Clearly, tariffs are better than quota auctions at raising revenue with imperfect competition. Not surprisingly, in all but some very special cases, free trade is at least as good as any quota. One of the special cases arises when some licenses are given away to foreign producers. In this event, a Pareto improvement over free trade can occur. By allowing a lower price to be set abroad than in the importing country, the quota allows price discrimination and higher profits to the exporter than would otherwise be possible. Giving away some of the licenses to the exporter allows the importing country and the exporter to share these gains, and price reductions in the rest of the world enhance their welfare as well.

\section{Giving Away Some Licenses}

With foreign product market power, if the Home country sells all of the licenses, incentives are created for the Foreign monopolist to raise the supply price to appropriate the quota rents. This incentive can be so strong that the license price becomes zero. Another factor becomes important, however, when the Foreign monopolist has some of the licenses. When the Home and Foreign markets are not segmented, a quota allows the Foreign monopolist to effectively discriminate in the price-but only in one direction: a quota allows a higher price to be charged to consumers in the quota-constrained Home market if the license price is positive.

When the foreign producer is a monopolist and the Home country sells all the licenses, the Foreign monopolist has an incentive to raise the supply price to appropriate the quota rents. If the Home country gives some of the licenses to the Foreign monopolist, there is less for the monopolist to gain by raising the price. By possessing some of the licenses, the Foreign monopolist can keep a portion of the quota rents. The monopolist benefits by pricing low and allowing a positive license price, which may also effectively segment the markets. Of course, doing so is worthwhile only if Home demand is less elastic than Foreign demand. Jones and Takemori (1989) use a general equilibrium model to make a similar point about how tariffs allow market segmentation.

With imperfect competition in the product market, therefore, giving away a portion of the import licenses to the Foreign producer is one way of raising revenue from the auctioning of quota licenses (Krishna 1991). ${ }^{6}$ Giving some of the licenses to the Foreign monopolist affects the pricing decision and forces the monopolist to consider not only profits, but also the value of the licenses. Giving

6. Bhagwati (1965) also emphasizes the importance of the implementation procedure in an auction quota and how it can affect the market structure. 
away quota licenses makes it more costly for the Foreign monopolist to raise the product price in order to extract the quota rents from the Home market. Keeping down the Foreign monopolist's price in turn raises the price of the licenses that remain in the hands of the Home country.

First consider a basic case in which the Foreign monopolist gets all the licenses and the quota is close to the free trade level. If Home demand is more elastic than Foreign demand, the Foreign monopolist will want to charge a lower price in the Home market, where the quota is imposed. But the quota permits only a higher price. Thus, the possibility of market segmentation is not valuable and only the incentive for rent appropriation remains. Hence, the price will be set so that the license has zero value. If Home demand is less elastic than Foreign demand, market segmentation is valuable and a license has a positive price even if the quota is set at the free trade level. In this case, markets are effectively segmented by the quota.

Varying the allocation of licenses and the level of the quota changes the relative importance of the incentives for rent appropriation and market segmentation. Allocating fewer licenses to the monopolist reduces the monopolist's gain from market segmentation and increases the monopolist's incentive to appropriate rent by raising the price. This implies a lower license price. Reducing the quota weakly raises the license price because it raises the cost of fully appropriating the quota rents.

The license price does not reflect the implicit tariff. Moreover, it is not clear whether the license price is above or below the implicit tariff. The license price depends on the allocation of the licenses and the level of the quota itself, and on differences in the demand elasticities in the Home and Foreign markets. Thus, the value of a license with a VER where all the licenses are given away differs significantly from the value of a license when all the licenses are auctioned.

The revenue effects are complicated because the revenues are the product of the number of licenses retained and the license price. Giving away licenses raises the license price, but can raise or lower revenues. Moreover, the welfaremaximizing choice of the quota and its allocation must take into account consumer surplus as well as revenue. Krishna (1991) presents the results of simulations in which the optimal levels of the quota and the share of licenses to the monopolist are calculated so as to maximize a weighted sum of license revenue and consumer surplus. The main results from these simulations are as follows.

In the first example, both the share of licenses retained and the quota level are set optimally. The license sales revenue is given the same weight as consumer surplus. Welfare exceeds that under free trade when Home elasticity is substantially smaller than Foreign elasticity and the Home country is relatively large. In this example, all parties gain from the optimal policy.

In the second example, license revenue is given greater weight in welfare. A quota becomes more desirable for revenue reasons, and the license price under the optimal policy tends to be positive. The results of the simulations also 
indicate that it is possible not only for domestic welfare to improve when such policies are set optimally, but also for the Foreign monopolist's profits and the Foreign country's welfare to rise.

The possibility that all parties could gain from such policies can be understood by noting that perfect price discrimination by a monopolist leads to maximization of world welfare (assuming, of course, that the world consists of the Home and Foreign countries only). Quotas can improve world welfare, because they allow price discrimination when the license price is positive. The gain can be distributed between the Home country and the Foreign country through the appropriate allocation of licenses so that all parties benefit.

Even in the case of many Foreign firms, the same policy can yield benefits to the Home country. Giving away some of the licenses affects the Foreign firms' pricing decisions; the Foreign firms charge lower prices when they have licenses, and this increases the value of the licenses (Tan 1990).

\section{Other Aspects of Quota Implementation}

Quotas are administered in practice in a variety of ways (see Trela and Whalley 1991). There are several different allocation schemes employed by quota-constrained developing countries under the MFA. Some countries, such as Pakistan, allocate licenses on the basis of the unit value of the order. They do so in hopes of raising foreign exchange earnings by encouraging exports of products having a higher value. This method of allocation could lead to overreporting of unit values. It is also a common practice to allocate licenses on the basis of past performance and to penalize license holders who underutilize their allocations, as is done in Hong Kong and Pakistan. In Hong Kong, a firm that transfers out 50 percent or more of its quota holding will have its quota allocation reduced in the following year. In Pakistan, the allocation of quotas is made against quarterly security deposits that increase each quarter. The purpose of these security deposits seems to be to encourage firms to use up their quota as early in the year as possible. Allocating quotas based on performance can encourage overuse of quotas in order to qualify for quotas in the future. This outcome is reflected in negative prices for quota licenses, such as the prices observed for ramie-cotton sweater panels knitted in Hong Kong in the latter half of 1988 .

There is little theoretical, and almost no empirical, work on how these regulations affect the behavior of participants in the quota-constrained market and the related license market, and on the costs and benefits of such practices. There is little guidance to governments with foreign exchange constraints (or other objectives) on how to structure the implementation of quotas. In general, the implementation of quotas is vastly understudied. Its importance is evident from the fact that under the MFA, for example, quotas from certain low-cost countries, such as Bangladesh, were not even close to being filled. 


\section{UNCERTAINTY AND DYNAMIC ELEMENTS}

The standard extensions of the basic model have focused on uncertainty. But, in practice, both uncertainty and dynamic considerations can be important, and for a number of reasons. First, uncertainty about demand or supply affects the restrictiveness of the quota and, consequently, its revenue and welfare effects (Dasgupta and Stiglitz 1977; Pelcovits 1979). Second, the price of a license, in the presence of uncertainty and dynamic elements, reflects more than the scarcity value captured in the simple static model. License holders have to be compensated for the opportunity cost of holding the license, and this makes the value of a license depend on factors such as the current state of demand, the remaining availability of licenses, and the time left before the license expires (Krishna and Tan 1992). Thus, interpreting the average license price over a year as the equivalent tariff may not be appropriate. Similarly, a jump in the license price may not indicate price fixing; the license price would increase if demand is unexpectedly high. Third, other aspects of implementation, such as how the quota is allocated and whether or not the licenses may be resold, can have unexpected effects, even in the presence of competition. For example, allocating quotas on a first-come-first-served basis can create a race to obtain the quota. Linking future allocations to utilization can create incentives to use existing licenses, leading to negative license prices. Transferable licenses need not raise more revenue than nontransferable ones under certain conditions (Tan 1992).

An interesting aspect of quotas in the real world is that they are valid for a year and can be used at any time in the year. In some cases, the licenses are also freely traded. ${ }^{7}$ The period of time in which it can be used, in combination with uncertainty in demand, gives the quota license an additional option value in the earlier months so that the license price tends to fall over the year. Krishna and Tan (1992) demonstrate the effect of this option value component by means of a simple two-period two-state example having infinitely elastic demand and supply (so that the license price is independent of the number of licenses remaining in the year). Denote by $L_{L}$ the license price in the low-demand state and $L_{H}$ the license price in the high-demand state. Then in the final period (period 2), the expected license price is $\pi L_{H}+(1-\pi) L_{L}$, where $\pi$ is the probability of the highdemand state and $(1-\pi)$ is, correspondingly, the probability of the lowdemand state. Let $\delta$ denote the discount rate. If period 1 is a high-demand state, then all the licenses will be used, because $L_{H}$ exceeds $\delta\left[\pi L_{H}+(1-\pi) L_{L}\right]$. If period 1 is a low-demand state, then as long as $\delta$ is not too small (that is, $\delta>$ $\left.L_{L} /\left[\pi L_{H}+(1-\pi) L_{L}\right]\right)$, none of the licenses will be used. The price at which a transaction would occur is $\delta\left[\pi L_{H}+(1-\pi) L_{L}\right]$, which is the price of any transaction in this state in the first period. The expected license price in period 1 is $\pi L_{H}+\delta(1-\pi)\left[\pi L_{H}+(1-\pi) L_{L}\right]$. The ex ante license price expected in period 2 is $(1-\pi)\left[\pi L_{H}+(1-\pi) L_{L}\right]$. Hence, the ex ante license price falls over 
time. Intuitively, the ex ante license price falls over time because in the first period the license holder has the option of not using his or her license and this option has value.

Krishna and Tan point out that this option value component of the license price is swamped if the arbitrage value of a license is endogenously determined by the demand and supply for licenses. In this case, only the asset value of a license remains, and the price of the license has to rise over the year at a rate of interest that will make people want to hold the license.

It is tempting to argue that increases in license prices over time indicate monopoly power. Prices would also be raised, however, by an unexpectedly high level of demand (accompanied by an increase in the use of licenses). A formal test of the price fixing of licenses requires that the implications of competitive pricing be specified in a dynamic model that has a closed form. In this way, the null hypothesis, that of competition, can be tested against the data.

Uncertainty and temporal aspects interact to produce an interesting and unexpected result in the comparison of transferable and nontransferable licenses. The standard argument is that transferable licenses are more efficient than nontransferable licenses because transferable licenses allow low-cost suppliers to obtain the licenses. The logic is that low-cost suppliers will value them more, and hence bid more for them. An implication of this is that transferable licenses will raise more revenue than nontransferable licenses will (Faini, de Melo, and Takacs 1992).

But this argument may not hold in the presence of uncertainty. Consider an example in which a supplier would value the license differently in two states. This could occur if there is a possibility that the supplier's capacity is exhausted by other orders. Assume that each agent wants at most one license. In state $A$ the valuation of a license is high, say 10 . In state $B$ it is low, say 0 . If the two states are equally likely, if all agents are identical, if licenses are nontransferable, and if the timing structure is such that licenses have to be obtained before the realization of the state, then each agent would only be willing to pay 5. Assume there are five agents and four licenses. Then the market price of a license would be 5 .

If licenses are transferable, then each agent would consider the market price of the license after the state was realized. In our example with four licenses and five agents whose valuations are independently distributed, the market price ex post will be 10 as long as at least four agents have a high realization. For our example, this probability can be verified to be 0.1875 . If less than four agents have a high realization, the value will be zero. This, of course, occurs with a probability of 0.8125 . Thus, the expected value before the state is known of all of the ex ante identical agents will be 1.875 . Note that this is less than 5 , the value of a nontransferable license.

It is easy to verify that this result is reversed if there are only two licenses but five agents. The reason is that without transferability, the price of a license is independent of the number of agents and licenses as long as the former exceeds the latter. With transferability, the value placed on a license ex ante depends on 
the price ex post. If the quota is very restrictive, the ex post price will be high on average, which causes a high ex ante price. If it is not very restrictive, the ex post price will be low on average, and this causes a low ex ante price. This argument, and an empirical application to the auction of vehicle quota licenses in Singapore can be found in Tan (1992).

\section{CONCLUSION}

The simple models described in this article illustrate why the basic competitive model may be inadequate for analyzing the outcomes of auction quotas in the real world. Even on the theoretical side, however, attention has been focused primarily on the effects of market power on the side of producers. Little attention has been paid to the consequences of market power on the side of buyers in the product market or in the license market, or on the consequences of different rules used in practice to implement quotas. Nor has much attention been paid to uncertainty and dynamic aspects. For policy purposes, it would be useful if such theoretical work were attempted and then supplemented with empirical work to test the validity of these new models and to determine the welfare consequences of such quotas and any proposed reforms. There have been some initial attempts to do so, and their results by and large show that the kinds of considerations reviewed here may well be more than theoretical curiosities.

\section{REFERENCES}

The word "processed" describes informally reproduced works that may not be commonly available through library systems.

Bergsten, C. Fred, Kimberly Ann Elliott, Jeffrey J. Schott, and Wendy E. Takacs. 1987. Auction Quotas and the United States Trade Policy. Washington, D.C.: Institute for International Economics.

Bhagwati, Jagdish N. 1965. "On the Equivalence of Tariffs and Quotas." In R. E. Baldwin and others, Trade, Growth, and the Balance of Payments: Essays in Honor of Gottfried Haberler. Chicago: Rand McNally.

Brander, James, and Barbara Spencer. 1985. "Export Subsidies and International Market Share Rivalry." Journal of International Economics 18: 83-100.

Caves, Richard E., and Joel B. Rosen. 1982. "Uncertainty, Transaction Costs, and the Size Distribution of Rival Firms: Theory and Evidence from the Women's Outerwear Industry." Quarterly Review of Economics and Business 22: 6-22.

Dasgupta, Partha, and Joseph Stiglitz. 1977. "Tariffs vs. Quotas as Revenue Raising Devices under Uncertainty." American Economic Review 67: 975-81.

Eaton, Jonathan, and Gene M. Grossman. 1986. "Optimal Trade and Industrial Policy Under Oligopoly." Quarterly Journal of Economics 101: 383-406.

Faini, Riccardo, Jaime de Melo, and Wendy E. Takacs. 1992. "A Primer on the MFA Maze." Paper before Workshop on E.C.-U.S. Trade Relations, March 13-14, European Centre for Advanced Research in Economics, Université Libre de Bruxelles, Brussels. Processed. 
Goto, Junichi. 1989. "The Multi-Fibre Arrangement and Its Effects on Developing Countries." The World Bank Research Observer 4: 203-27.

Hamilton, Carl. 1986. "An Assessment of Voluntary Restraints on Hong Kong Exports to Europe and the USA." Economica 53: 339-50.

Helpman, Elhanan, and Paul Krugman. 1989. Market Structure and Trade Policy. Cambridge, Mass.: MIT Press.

Jones, Ronald W., and Shumpei Takemori. 1989. "Foreign Monopoly and Optimal Tariffs for the Small Open Economy." European Economic Review 33: 1691-707.

Krishna, Kala. 1989a. "Trade Restrictions as Facilitating Practices." Journal of International Economics 26: 251-70.

- 1989b. "What Do vers Do?" In Julianne Nelson and Ryuzo Sato, eds., Beyond Trade Friction. New York: Cambridge University Press.

- 1990a. "The Case of the Vanishing Revenues: Auction Quotas With Monopoly." American Economic Review 80: 828-36.

. 1990b. "Auctions with Endogenous Valuations: The Persistence of Monopoly Revisited." HIER Working Paper No. 1513, forthcoming American Economic Review 1992.

1990c. "Auctions with Endogenous Valuations: The Snowball Effect and Other Applications." NBER Working Paper No. 3483. National Bureau of Economic Research, Cambridge, Mass. Processed.

- 1991. "Making Altruism Pay in Auction Quotas." In Elhanan Helpman and Assaf Razin, eds., International Trade and Trade Policy. Cambridge, Mass.: MIT Press.

. 1992. "The Case of the Vanishing Revenues: Auction Quotas with Oligopoly." NBER Working Paper No. 2723, forthcoming in Wilfried Ethier, Elhanan Helpman, and Peter Neary, eds., 1992. Theory, Policy and Dynamics in International Trade.

Krishna, Kala, Refik Erzan, and Ling Hui Tan. 1991. "Rent Sharing in the Multi-Fibre Arrangement: Theory and Evidence from U.S. Apparel Imports from Hong Kong." NBER Working Paper No. 3673. National Bureau of Economic Research, Cambridge, Mass. Processed.

Krishna, Kala, Will Martin, and Ling Hui Tan. 1992. "Imputing License Prices: Limitations of a Cost Based Approach." Fletcher School of Law and Diplomacy, Tufts University, Medford, Mass. Processed.

Krishna, Kala, and Ling Hui Tan. 1992. "License Price Paths in the Multi-Fibre Arrangement." Fletcher School of Law and Diplomacy, Tufts University, Medford, Mass. Processed.

McCulloch, Rachel. 1973. "When Are a Tariff and a Quota Equivalent." Canadian Journal of Economics 6: 503-11.

Pelcovits, Michael D. 1979. "The Equivalence of Quotas and Buffer Stocks as Alternative Stabilization Policies." Journal of International Economics 9: 303-07.

Rubinstein, Ariel. 1982. "Perfect Equilibrium in a Bargaining Model." Econometrica 50: 97-109.

Shibata, Hirofumi. 1968. "A Note on the Equivalence of Tariffs and Quotas." American Economic Review 58: 137-42.

Takacs, Wendy. 1990. "Import License Auctions in Trade Liberalization: Australia, New Zealand, and Colombia." World Bank, Trade Policy Division, Country Economics Department, Washington, D.C. Processed. 
Tan, Ling Hui. 1990. "Notes on the Implementation of Auction Quotas." Harvard University, Department of Economics, Cambridge, Mass. Processed.

. 1992. "License Transferability and Quota Premia: Evidence from Singapore's Vehicle Quota Auctions." Harvard University, Department of Economics, Cambridge, Mass. Processed.

Tarr, David G. 1989. "A General Equilibrium Analysis of the Welfare and Employment Effects of U.S. Quotas on Textiles, Autos, and Steel." Federal Trade Commission, Washington, D.C.

Trela, Irene, and John Whalley. 1991. "Internal Quota Allocation Schemes and the Costs of the MFA." NBER Working Paper No. 3627. National Bureau of Economic Research, Cambridge, Mass. Processed. 


\section{Data on the Former Soviet Union \\ Now Available}

\section{World Debt Tables 1992-93}

\section{External Finance for Developing Countries}

This new edition of the World Bank's invaluable annual reference guide provides complete and up-to-date information on the debt of developing countries, including for the first time key data on the Former Soviet Union.

Volume I analyzes recent developments in international finance for developing countries and summarizes statistical tables for selected regional and analytical groups. Volume II provides statistical tables for 116 countries, including the countries of the Former Soviet Union.

Periodic supplements to World Debt Tables will be published throughout the year as new data become available. Subscribers will receive these supplements at no extra cost.

Volume I Analysis and Summary Tables 230 pages / ISBN 0-8213-2226-5/US\$16.95 / Order Stock \#12226

Volume II Country Tables

506 pages / ISBN 0-8213-2227-X / Not sold separately

Volume I \& II with supplements

ISBN 0-8213-2313-X/US\$125.00/ Order Stock \#12313

Also Available

World Debt Tables 1992-93 — Data on Diskette ISBN 0-8213-2358-X/US\$95.00/ Order Stock \#12358

To order World Debt Tables please use the coupon that follows. 


\section{New Edition Includes \\ Data on the Former Soviet Union}

\section{World Bank Atlas \\ 25th Anniversary Edition}

This 25th Anniversary Edition of the World Bank's most popular collection of data has been revised and expanded. It includes information on more topics than ever before, arranged in a new, easyto-use format.

Key social and economic data for 200 economies - including the countries of the Former Soviet Union - are organized under three development themes: The People, The Economy, and The Environment. Introductory texts explain the role each theme has in world development

Each section contains five maps with corresponding information on topics such as fertility, illiteracy, population growth, child mortality, school enrollment, female labor, and daily calorie supply.

In the new section on the environment, data are presented on deforestation, water use, energy consumption, and land use, as well as oil consumption.

Text appears in English, French, and Spanish. Easy-to-read world maps, tables, and graphs make this an ideal reference for office or classroom.

\section{World Bank Atlas}

25th Anniversary Edition

36 pages / ISBN 0-8213-1977-4 / US\$7.95 / Order Stock \#11977

To order the World Bank Atlas please use the coupon that follows. 


\section{New From \\ the International \\ Finance Corporation}

\section{Trends in Private Investment in Developing Countries 1993}

\section{Statistics for 1970-91}

Guy P. Pfeffermann and Andrea Madarassy

This study presents statistical data on private investment trends in forty-seven developing countries. It updates the previous edition with information through 1991 and focuses on foreign direct investment as an element of private investment.

Tables cover key investment topics such as gross domestic product, annual investment averages, and investment shares for different regions. Graphs and charts provide quick appraisal of private, public, and total investment trends in each country.

IFC Discussion Paper 16

Trends in Private Investment in Developing Countries 1993 70 pages / ISBN 0-8213-2311-3 / US6.95 / Order Stock \#12311

\section{To order Trends in Private Investment} in Developing Countries 1993 please use the coupon that follows. 


\section{New World Bank Series}

\section{The Political Economy}

of Agricultural Pricing Policies

\section{A World Bank Comparative Study in Five Volumes}

This new series of comparative studies from the World Bank examines how policies have affected agriculture in eighteen developing countries. The five volumes consider the impact of both direct policies toward agriculture and of general development policies on incentives confronting agricultural producers and on agriculture's contribution to development.

In these volumes, the authors show how general policies can have effects more powerful than direct policies on incentives. The three regional volumes estimate price discrimination against agriculture in individual countries, how it has changed over time, and the political-economic factors that guided the evolution. They also evaluate the effects of this price discrimination on such key macroeconomic variables as foreign exchange earnings, agricultural output, and income distribution.

Two synthesis volumes draw on the full range of country experience to give insight into the motivations of policymakers, the economic and political factors determining agricultural interventions, and the attempts to reform unsuccessful policies.

Published for the World Bank by the Johns Hopkins University Press

Volume 1: Latin America

Edited by Anne O. Krueger, Maurice Schiff, and Alberto Valdés 288 pages / ISBN 0-8018-4029-5 / US\$32.95 / Order Stock \#44029

Volume 2: Asia

Edited by Anne O. Krueger, Maurice Schiff, and Alberto Valdés 293 pages / ISBN 0-8018-4030-9 / US\$32.95/ Order Stock \#44030

Volume 3: Africa and the Mediterranean

Edited by Anne O. Krueger, Maurice Schiff, and Alberto Valdés 360 pages / ISBN 0-8018-4031-7/ US\$32.95 / Order Stock \#44031

Volume 4: Synthesis of the Economics in Developing Countries Maurice Schiff and Alberto Valdés

284 pages / ISBN 0-8018-4531-9 / US\$32.95 / Order Stock \#44531

Volume 5: A Synthesis of the Political Economy in Developing Countries Anne O. Krueger

176 pages / ISBN 0-8018-4294-8 / US\$32.95 / Order Stock \#44294

To order any of these volumes

please use the coupon that follows. 


\section{World Bank Publications Order Coupon}

\section{CUSTOMERS IN THE UNITED STATES:}

Complete this coupon and return to

World Bank Publications

Box 7247-8619

Philadelphia, PA 19170-8619

U.S.A.

To have your order shipped faster, charge by credit card by calling (202) 473-1155 or send this completed order coupon by facsimile by dialing (202) 676-0581.
CUSTOMERS OUTSIDE THE UNITED STATES:

Contact your local World Bank Publications distributor for information on prices in local currency and payment terms. (A complete list of distributors follows this coupon.) If no distributor is listed for your country, use this order form and return it to the U.S. address. Orders that are sent to the U.S. address from countries with distributors will be returned to the customer.

\begin{tabular}{c|c|c} 
Title & Stock Number & Price \\
\hline & & \\
\hline & & \\
\hline & & \\
\hline
\end{tabular}

Subtotal US\$

Postage and Handling* US\$

Total US\$

* If purchase order is used, actual postage will be charged. If payment is by check or credit card, postage and handling charges are $\$ 3.50$ per order. For air mail delivery outside the U.S., include an additional US\$6.00 per item.

\section{CHECK METHOD OF PAYMENT}

Enclosed is my check payable to World Bank Publications.
$\square$ Charge my $\square$ VISA
MasterCard
American Express

\section{Credit card account number}

Expiration Date

Signature

Bill me. (Institutional customers only. Purchase order must be included.)

\section{PLEASE PRINT CLEARLY}

Name

Firm

Address

City State Postal Code

Country Telephone 


\section{Distributors of World Bank Publications}

Prices and credit terms vary from country to country. Consult your local distributor before placing an order.

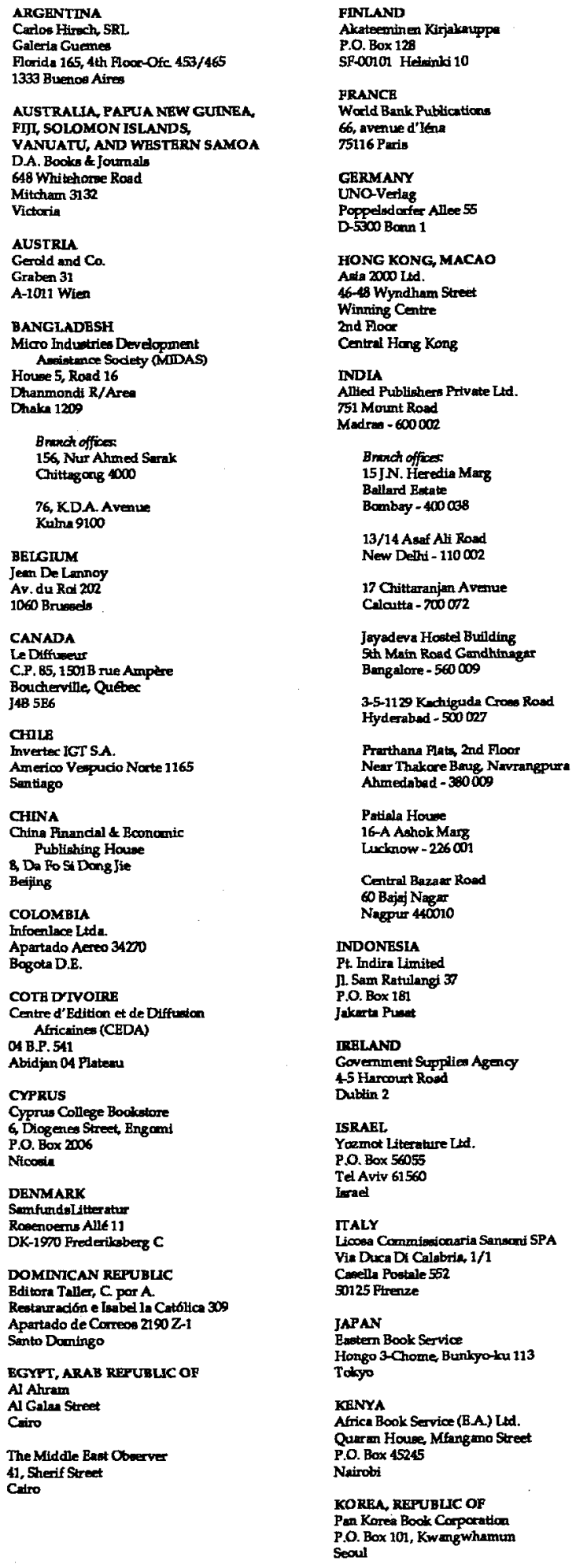

\begin{tabular}{|c|c|}
\hline 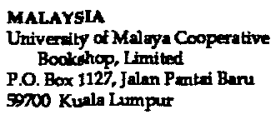 & $\begin{array}{l}\text { SPAIN } \\
\text { Mindi-Prensu Libion SA. } \\
\text { Combelo } 37 \\
\text { 28001 Madrid }\end{array}$ \\
\hline MExico & $\begin{array}{l}\text { Litreria Internacionel AEDOS } \\
\text { Convell de Cent, } 39 \text {. }\end{array}$ \\
\hline $\begin{array}{l}\text { NFOTRC } \\
\text { Apertado Poetal 22-B60 }\end{array}$ & 00009 Barcolona \\
\hline 14060 Thalpan, Medioo D.F. & $\begin{array}{l}\text { SRI LANKA AND TFE MAIDIVES } \\
\text { Lake Houve Boolchhop }\end{array}$ \\
\hline $\begin{array}{l}\text { NETHERLANDS } \\
\text { De Lindeboom/lhor-Publikatles } \\
\text { P.O. Box } 202 \\
\text { 74:0 AB Halksbergen }\end{array}$ & $\begin{array}{l}\text { P.0. Box } 24 \\
\text { 100, sor Chittumpalan A. } \\
\text { Gardiner Mewath }\end{array}$ \\
\hline 7420 AB Halksbergen & Colombo 2 \\
\hline $\begin{array}{l}\text { NEW ZEALAND } \\
\text { BBSCO NZ Ltd. } \\
\text { Private Mail Bag } 99914 \\
\text { New Market } \\
\text { Aucklend }\end{array}$ & 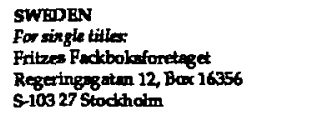 \\
\hline $\begin{array}{l}\text { NIGERIA } \\
\text { Univerithy Press Limited } \\
\text { Three Crowns Burilding Jedtito } \\
\text { Private Mail Bag } 5095 \\
\text { Ibadrm }\end{array}$ & 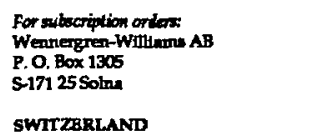 \\
\hline $\begin{array}{l}\text { NORWAX } \\
\text { Narvesen Information Center } \\
\text { Book Depintment } \\
\text { P.O. Box } 6125 \text { Ettersed } \\
\text { N0602 ONo } 6\end{array}$ & $\begin{array}{l}\text { SWITzBRLAND } \\
\text { For single titles: } \\
\text { Lhraurie Payot } \\
\text { 1, rue de Bourg } \\
\text { CH } 1002 \text { Lnusinne }\end{array}$ \\
\hline $\begin{array}{l}\text { PAKaST AN } \\
\text { Mrrza Book Agency } \\
\text { 65, Shahrahth-Quaid-e-Azmm } \\
\text { P.O. Box No. } 729 \\
\text { Lahore } 54000\end{array}$ & 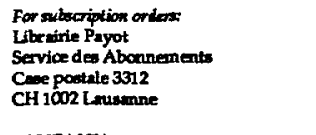 \\
\hline $\begin{array}{l}\text { PERU } \\
\text { Bditorial Desarrollo SA } \\
\text { Apartado } 3824 \\
\text { Limn } 1\end{array}$ & 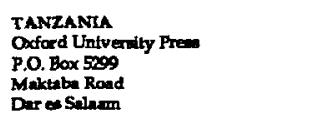 \\
\hline $\begin{array}{l}\text { PHILIPPANBS } \\
\text { mbernational Book Center } \\
\text { Fifth Floor, Flipinas Life Building } \\
\text { Ayala Avenue, Makat } \\
\text { Metro Mraila }\end{array}$ & $\begin{array}{l}\text { THNILAND } \\
\text { Central Depertment Sture } \\
306 \text { Stlow Road } \\
\text { Bengikok } \\
\text { TRINIDAD \& TOBAGO, ANTIGUA }\end{array}$ \\
\hline $\begin{array}{l}\text { POLAND } \\
\text { international Publithing Service } \\
\text { Un. Riekn } 31 / 37 \\
\infty 0-67 \text { Warzawa }\end{array}$ & $\begin{array}{l}\text { TRINIDAD \& TOBAGO, ANTIGUA } \\
\text { BARBUDA, BARBADOS, } \\
\text { DOMGNICA, GRENADA, GUYANA, } \\
\text { JAMAICA, MONTSERRAT, ST. } \\
\text { KTTTS \& NEVIS, ST. LUCCA } \\
\text { ST. VINCENT \& GRENADINES }\end{array}$ \\
\hline $\begin{array}{l}\text { For subscription oriens } \\
\text { IPS Journals } \\
\text { UI. Okrema } 3 \\
\text { O2-916 Warrerawa }\end{array}$ & $\begin{array}{l}\text { Syotem atios Studies Unit } \\
\text { s Watts Street } \\
\text { Curepe } \\
\text { Trinidud, Weat Indies }\end{array}$ \\
\hline $\begin{array}{l}\text { PORTUGAL. } \\
\text { Livrarin Partugal } \\
\text { Rum Do Curmo } 00-74 \\
1200 \text { Lisbon }\end{array}$ & $\begin{array}{l}\text { TURKEY } \\
\text { fnfoted } \\
\text { Narlabuhge Sok. No. } 15 \\
\text { Cegaloglu } \\
\text { Ittenbuil }\end{array}$ \\
\hline $\begin{array}{l}\text { SAUDI ARABLA, QATAR } \\
\text { Jartr Book Store } \\
\text { P.O. Box } 3196 \\
\text { Riyedh } 11471\end{array}$ & $\begin{array}{l}\text { UNITED KDNGDOM } \\
\text { Microinfo Led. } \\
\text { P.O. Box } 3 \\
\text { Alton, Hampehire GLB34 2PG }\end{array}$ \\
\hline $\begin{array}{l}\text { SINGAPORE, TANWAN, } \\
\text { MYANMAR, BRUNEI } \\
\text { Information Publicitions } \\
\text { Private, Led. } \\
\text { Golden Whet Butilding } \\
\text { 41, Kallarg Pudding, f0403 } \\
\text { Singapore } 1334\end{array}$ & 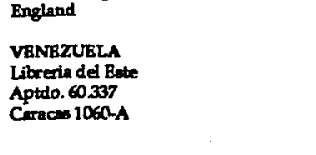 \\
\hline $\begin{array}{l}\text { SOUTH AFRUCA, EOTSWANA } \\
\text { For single tilles } \\
\text { Oxford Univernity Press } \\
\text { Southem Africa } \\
\text { P.O. Box 1141 } \\
\text { Cope Town } 8000\end{array}$ & \\
\hline $\begin{array}{l}\text { For subcriqtion oriess } \\
\text { International Subectiption Service } \\
\text { P.O. Box } 41095 \\
\text { Craighall } \\
\text { Johrnnesburg } 2024\end{array}$ & \\
\hline
\end{tabular}




\title{
Coming in the next issue of THE WORLD BANK ECONOMIC REVIEW
}

\author{
May 1993 \\ Volume 7, Number 2
}

Articles on ...

- Modeling the Macroeconomic Effects of AIDS in Tanzania by John T. Cuddington

- Sovereign Debt

by Jonathan Eaton

- Piecemeal Trade Reform in the Partially Liberalized Economy of Turkey

by Glenn W. Harrison, Thomas F. Rutherford, and David G. Tarr

- Substitution and the Impact of Transport Taxation in Tunisia

by Gordon Hughes

- A Medium-Term Analysis of the Real Exchange Rate in the Philippines and Tanzania

by Kathie L. Krumm

- An Institutional Analysis of the Design and Sequencing of Trade and Investment Policy Reform

by Brian Levy 